H. Hoyskolen

\title{
Ledelse av mennesker i det nye arbeidslivet
}

Jarle Bastesen, Birthe Kåfjord Lange,

Hans Erik Næss og Andreas N. Thon (red.) 
Ledelse av mennesker i det nye arbeidslivet 

Jarle Bastesen, Birthe Kåfjord Lange,

Hans Erik Næss og Andreas N. Thon (red.)

\section{Ledelse av mennesker i det nye arbeidslivet}


(C) 2020 Jarle Bastesen, Birthe Kåfjord Lange, Hans Erik Næss, Andreas N. Thon, Nils Arne Bakke, Jens Barland, Arild Fetveit, Rune Bjerke, Irmelin Drake, Thea Renate Berg, Elin Ørjasæter, Mari Svendsen, Ola Martin Jensen Larsen, Anna Haugen Gausdal og Helene Trondstad Moe.

Dette verket omfattes av bestemmelsene i Lov om opphavsretten til åndsverk m.v. av 1961. Verket utgis Open Access under betingelsene i Creative Commons-lisensen CC-BY 4.o (http://creativecommons.org/licenses/by/4.o/). Denne tillater tredjepart å kopiere, distribuere og spre verket i hvilket som helst medium eller format, og å remixe, endre, og bygge videre på materialet til et hvilket som helst formål, inkludert kommersielle, under betingelse av at korrekt kreditering og en lenke til lisensen er oppgitt, og at man indikerer om endringer er blitt gjort. Tredjepart kan gjøre dette på enhver rimelig måte, men uten at det kan forstås slik at lisensgiver bifaller tredjepart eller tredjeparts bruk av verket.

Boka er utgitt med støtte fra Høyskolen Kristiania.

ISBN trykt bok: 978-82-02-70289-2

ISBN PDF: 978-82-02-69335-O

ISBN EPUB: 978-82-02-71093-4

ISBN HTML: 978-82-02-71094-1

ISBN XML: 978-82-02-71095-8

DOI: https://doi.org/10.23865/noasp.118

Dette er en fagfellevurdert antologi.

Omslagsbilde: Jacob Wackerhausen/Getty

Omslagsdesign: Cappelen Damm AS/Høyskolen Kristiania

Cappelen Damm Akademisk/NOASP

noasp@cappelendamm.no 


\section{Innhold}

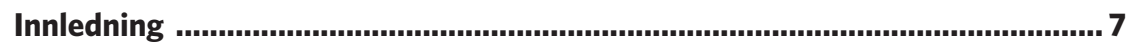

Hans Erik Næss

Kapittel 1 Business Model Transformation of Legacy Newspapers in The Age of The Digital Attention Economy 19

Nils Arne Bakke, Jens Barland \& Arild Fetveit

Kapittel 2 Helseledelse på arbeidsplassen - sunn

prestasjonskultur og individuelle HR-drivere bak

organisatoriske prestasjoner

Rune Bjerke

Kapittel 3 Selvledelse som mulighet i kunnskapsorganisasjoner:

Trengs andre selvledelsesstrategier?

Irmelin Drake

Kapittel 4 Gårsdagens suksess - morgendagens begrensning?

Strategisk relevant handlingsrom: En rikere forståelse av leders handlingsrom

Jarle Bastesen og Birthe Kåfjord Lange

Kapittel 5 Oppdragsbasert ledelse: Ledelse og styring gjennom

intensjoner 135

Andreas Thon og Thea Renate Berg

Kapittel 6 Frelsere eller parasitter? Ledermotiver for bruk av

IT-konsulenter 163

Jarle Bastesen og Elin Ørjasæter

Kapittel 7 Forgrønning av motorsport gjennom innovativ eventledelse. En casestudie av Zürich E Prix 2018 185

Hans Erik Næss og Rune Bjerke 
INNHOLD

Kapittel 8 «Vi vil børste vekk asken, men holde liv i ilden.»

En kvalitativ studie av et mentorprogram for unge idrettsledere

Birthe Kåfjord Lange og Hans Erik Næss

Kapittel 9 Arbeidsinkludering: En organisatorisk diamant 231 Mari Svendsen og Ola Martin Jensen Larsen

Kapittel 10 Hvordan påvirker tillit og psykologisk trygghet implementering av radikale endringer?

En casestudie av digital tjenesteteknologi 257

Birthe Kåfjord Lange og Anne Haugen Gausdal

Kapittel 11 Hvorfor er effektiv ledelse så sjelden? 279

Helene Tronstad Moe

Forfatterbiografier 303 


\title{
Innledning ${ }^{1}$
}

\author{
Hans Erik Næss
}

Høyskolen Kristiania

«Framtidens arbeidsliv» er noe som opptar forskere, OECD, konsulentselskaper, ledergrupper og internasjonale arenaer som World Economic Forum. Foruten mer eller mindre begrunnede påstander om utviklingstrekk, farer og muligheter, byr forfattere og kunstnere også på kreative visjoner om hvordan nye oppfinnelser og leveformer vil påvirke hvordan vi kommer til å tjene til livets opphold. I sjangeren inspirerende sitater finnes det et utall referanser til framtida. For eksempel skrev den visjonære medieforskeren Marshall McLuhan på 1960-tallet sammen med en kollega at arbeidslivet framover vil handle om at folk «will not so much earn a living as learn a living» (McLuhan \& Leonard, 1967, s. 25). Alle mener noe om framtiden, ikke minst når våre forestillinger om den utfordres av kriser og trusler mot samfunnsformasjonen slik vi kjenner den.

Uten å avfeie verdien av framtidsvyer, kan det likevel påstås at mange av dem har en tidshorisont som er for abstrakt til å være relevant for organisasjoner flest og folks arbeidshverdager. Samtidens prinsipper og praksiser, som i nær framtid vil måtte omgjøres og diskuteres på ny, er langt mer aktuelle å forholde seg til for de fleste av oss. Der man i gamle dager opplevde arbeidslivet som fysisk belastende, kollektivistisk og plassert ved siden av hverdagslivet, kan dagens kunnskapssamfunn være individualisert, mentalt utfordrende og stressende - samtidig som privatlivet

1 Takk til Jarle Bastesen, Andreas N. Thon og Nils Arne Bakke for innspill og kommentarer til
innledningen. Takk også til alle involverte i Cappelen Damm for godt samarbeid og god sparring
underveis.

Sitering av denne artikkelen: Næss, H. E. (2020). Innledning. I J. Bastesen, B. K. Lange, H. E. Næss \& A. N. Thon (Red.), Ledelse av mennesker i det nye arbeidslivet (s. 7-18). Oslo: Cappelen Damm Akademisk. https://doi.org/10.23865/noasp.118.cho

Lisens: CC-BY 4.0. 
føres mer og mer inn i arbeidslivet, da vi er pålogget og påskrudd omtrent hele døgnet. Støtte for dette synet finnes i små gjøremål så vel som store forskningsprosjekter. Et eksempel på førstnevnte sirkulerte på LinkedIn under pandemivåren 2020, hvor covid-19 tvang svært mange arbeidstagere over på hjemmekontor og ledere inn i avstandsledelse. Redningsselskapet (RS) valgte da å bruke pengene som vanligvis gikk til kaffe og frukt på arbeidsplassen, til å sende godsaker via Morgenlevering.no til sine ansatte med oppfordringen: «Husk kaffepauser med litt kos, hilsen ledelsen i RS». Noen eksempler på sistnevnte er «The Global Future of Work», et prosjekt satt i gang i 2019 av Den internasjonale arbeidsorganisasjonen (ILO) i forbindelse med sitt 100-årsjubileum, mens norske FAFO er inne i sluttfasen av prosjektet «The Future of Work - Opportunities and Challenges for the Nordic Models» (NFoW 2017-2020).

Begge prosjektene betoner viktigheten av å komme nærmere inn på hva som fungerer og ikke i dagens arbeidsliv, i stedet for å vektlegge hvordan det bør være. Denne boka du nå leser i, som er den første av flere antologier fra oss på Institutt for ledelse og organisasjon ved Høyskolen Kristiania om dette temaet, er vår uavhengige skjerv til å forstå og forklare denne utviklingen. Til forskjell fra mye av norsk arbeidslivsforskning, der fokuset er på ansatte, organisasjoner eller samfunnsstrukturer, tar vi utgangspunkt i ledelsesfaget. Med utgangspunkt i kapitlene fra denne boka, som alle er skrevet av forskere og undervisere ved Høyskolen Kristiania, mener vi at ledelsesfaget har mye å lære fra aktuelle problemstillinger og gjøremål i dagens Norge der mennesket er i fokus. Det gjør vi fordi det å ta mennesker på alvor som premissleverandør for trivsel, effektivitet og produktivitet bringer med seg mange ringvirkninger. Disse ringvirkningene kan være positive og/eller negative, ha betydning på kort eller lengre sikt, påvirke både hverdagsledelse og store visjoner, og krever derfor nye perspektiver på ledere, ledelse og lederskap.

\section{Tre årsaker til bokas perspektiver på ledere, ledelse og lederskap}

Den første årsaken handler om hvordan vi skal forholde oss til teknologiens påvirkning. I tråd med det siste århundrets debatt om ny teknologi i 
arbeidslivet preges dagens samtale av like deler frykt og fascinasjon. Der vi på 1990-tallet brukte ord som cyberspace, dotcom og netizen kastes nå ord som digitalisering, big data og tingenes internett rundt i offentligheten som om de vil medføre en helt ny verdensorden. Og ja, de er selvfølgelig en del av det store bildet. Enkelte teknologiske innovasjoner, som smarttelefonen, har de siste to tiårene forandret store deler av arbeidslivet. Samtidig er det liten enighet om hvor omfattende disse endringene er, og hvor stor makt teknologien har fătt. Det er ingen tvil om at kunstig intelligens generelt (AI) og maskinlæring spesielt gir sektorer som media, bilindustrien, og helsevesenet store muligheter for å utvikle bedre tilpassede tjenester. Utviklingen av smarte, lærende AI-agenter, som overtar også kompetansedrevne beslutninger fra mennesker og kommuniserer som om de hadde menneskelig intelligens, peker mot nye organisasjonsformer bygget på programvare. Dette gjør ikke menneskelig ledelse og menneskelige beslutninger overflødige, men skaper nye utfordringer og muligheter for lederskap og arbeidsorganisering (Iansati \& Lakhtani, 2019; McAfee \& Brynjolffson, 2017). Leger kan anvende AI til pasientoppfølging, eller såkalt klinisk beslutningsstøtte, der algoritmer kan trenes til å tolke røntgenbilder. Samtidig er det fortsatt, og vil være i overskuelig framtid, mennesker - i dette tilfellet leger - som tar avgjørelsen om å operere eller ikke, eller strategiske beslutninger som angår ytterligere digitalisering av virksomheten man leder. Det er fortsatt mennesker som snakker med folk, og ikke minst ser for seg hva morgendagen vil bringe av endringer i arbeidslivet - framfor alt på ledernivå. Dessuten er det mer enn bare effektivitet og produktivitet som definerer en arbeidsplass. Tiltro til hverandre, empati med hverandre, og det å finne mening i det man driver med er viktige perspektiver i en tid der Harvard Business Review ser seg nødt til å lage en artikkelserie kalt «How to be human at work», og skillet mellom arbeid og livsstil for lengst er forlatt (Chavez \& Palsule, 2020).

Den andre årsaken er at arbeidsstokken er mer sammensatt enn tidligere. Det mest åpenbare beviset er kvinners inntreden i betalt arbeid og betydningen dette har hatt på samfunnsformasjonen generelt. Eksempelvis fant en studie av Wyndow, Li og Mattes (2013) en sterk sammenheng mellom demokratisk utvikling i ulike land og kvinnelig inntreden 
i utdanning og arbeidsliv mellom 1980-2005. Men selv om mangfoldets betydning allerede er understreket av mye forskning og de økonomiske bevisene på dets fordeler er sterke, ligger det likevel et kulturelt etterslep i mange bransjer og regioner av verden. Dette etterslepet går ut over inkludering og integrering av kvinner, minoriteter og mennesker med ekstra fysiske eller psykiske behov, så vel som ansatte og ledere med ulike væremåter knyttet til livsstil (Brenna \& Solheim, 2018; Kirton, 2020; Klingler-Vidra, 2019). Deler av dette har med organisasjonskultur å gjøre. Rivera (2012) avdekket i sin intervjustudie av 120 arbeidsgivere at de foretrakk arbeidstagere som var like dem selv når det kom til fritidsinteresser, erfaringer og selvrepresentasjon. Mens den uttalte årsaken var å sikre seg mot en svak organisasjonskultur, ble resultatet det motsatte. En sterk organisasjonskultur forutsetter i mange tilfeller rom for de ansatte til å være forskjellige (Mazur, 2014; Pless \& Maak, 2004). Desto viktigere er det å undersøke hvordan bedrifter, organisasjoner og offentlig sektor kan skape sin variant av cultural add-filosofien (der mangfold er en styrke fordi det fremmer nytenkning), som i mange bransjer er langt mer relevant enn cultural fit (der tilpasning til fellesskapet er viktigere enn individuell frihet) (McCord, 2018). Grunnen til at Accenture ble kåret til den beste arbeidsgiveren for mangfold og inkludering på Refinitiv Diversity \& Inclusion i 2018 og 2019, som tar for seg de 100 største børsnoterte bedriftene i verden, kan eksempelvis forklares med at de legger vekt på «a culture of cultures» (Nanterme, 2018). Samtidig er det viktig å påpeke at detaljert organisasjonsbygging kan havne i veien for intensjonene bak den. Summen av ringvirkninger på aggregert nivå kan bli noe annet enn det som var hensikten med å innføre for eksempel en kulturorientert rekrutteringspolicy på individnivå. Årsaken, ifølge Harris og Ogbonna, er «den menneskelige naturs uforutsigbarhet» (2002, s. 46, min oversettelse). Hvis kultur brukes som verktøy for å skape en effektiv organisasjon med tilfredse ansatte, bør ledere i så fall ta høyde for at kulturintervensjonens betydning evalueres etter strenge kriterier. Blant disse finner vi både intervensjonens intensjon, gjennomføring og hvordan dens utilsiktede konsekvenser ble håndtert (Harris \& Ogbonna, 2002).

Den tredje årsaken er at endringene i måten vi jobber på er en del av akselerasjonsprosesser i samfunnet. Den tyske sosiologen Hartmut Rosa 
skrev for snart et tiår siden (Rosa, 2013) at akselerasjonen nærmer seg en samfunnspatologi - en tilstand hvis utilsiktede konsekvenser hindrer folk i å leve det gode liv. En grunn til det er at enkelte akselerasjonsprosesser, som innen teknologi, er målrettete og formålsstyrte, mens andre akselerasjonsprosesser - for eksempel de som påvirker individers karrierevalg tilsynelatende er mindre kontrollert. Funn presentert i en rapport fra Hammer og Falkman (2018), som bygger på Nordic Executive Survey, peker i denne sammenheng på et interessant paradoks. På den ene siden opplever en god majoritet raske endringer som noe positivt. På den andre siden oppgir nesten fire av ti at arbeidet blir annerledes, stresset øker, og at endringene presses på dem. Dette spriket fører til usikkerhet om egne valg, det reduserer læringsevnene, og er paradoksalt nok med på å øke jobbskiftetakten. Grepene for å hindre at dette spriket øker, må derfor ta utgangspunkt i en bred samfunnsforståelse i stedet for en snever businesslinse. Anders Lier, toppleder i EXP Group og Nordic Impact, skrev i E24 i 2017 at «Hele 57 prosent av millenials i lederposisjoner planlegger å slutte i løpet av fire år. Den tradisjonelle corporate-modellen virker ikke lengre. Dermed må topplederne også ta en ny rolle. I hvert fall hvis de skal hjelpe det nye Norge med å akselerere» (Lier, 2017). Samvirkningen av akselerasjon og det Dølvik og Steen (2019, s. 9) kaller fragmenterte tilknytningsformer og atypisk arbeid, skaper videre store utfordringer for den norske eller nordiske modellen (altså det etablerte forholdet mellom arbeidsgiver- og arbeidstagernes hovedorganisasjoner og staten):

Gitt omstillingene som vil følge av overgangen til framtidens grønne, digitaliserte økonomi, er et kritisk spørsmål hvorvidt organisasjonene i arbeidslivet og særlig det lokale partssamarbeidet fortsatt vil være i stand til å håndtere omstillingsutfordringene. Konfrontert med økende outsourcing og oppsplitting av arbeidsoppgaver til småjobber eller «gigs» i digitaliserte, transnasjonale produksjonssystemer vil det neppe bli lett for partene å reversere tendensene til forvitring av den nordiske modellen i flere sektorer. (Dølvik \& Steen, 2019, s. 9)

Selv om reversering av disse tendensene er vanskelige, teknologiens rolle er uforutsigbar og arbeidsstokkens mangfold krever andre tilnærminger til ledelse enn før, er det håp for norsk arbeidsliv. Forståelse og ledelse i det nye arbeidslivet krever imidlertid en kombinasjon av klassiske og nye, 
nasjonale og internasjonale perspektiver på hvordan det organiseres på individ-, gruppe-, og organisasjonsnivå. For å bevare den norske modellens styrker må vi undersøke dens svakheter (se f.eks. Bungum, Forseth \& Kvande, 2015). For å sikre effektiv drift, økonomisk bærekraft og ikke minst god håndtering av menneskene på ulike steder i organisasjonskartet, kan man ikke lene seg ukritisk på etablerte sannheter og «slik har vi alltid gjort det her»-argumenter. Det betyr naturligvis ikke at fortidens forskningsfunn eller praksiser er utdaterte. Vår holdning er tvert imot at de må integreres mer presist i arbeidslivets egen virkelighet, både i samtidens forskning og med tanke på framtidige utfordringer.

I denne boka gjør vi derfor et forsøk på å binde sammen ny forskning på utvalgte felt med vitenskapelig etablerte teorier og metoder for å fornye innsikten i arbeidslivsledelse. Boka handler ikke bare om hva ledelse er, eller bør være, men hvordan det brukes som et virkemiddel og samtidig utvikles som selvstendig fagfelt. Noen vil kanskje innvende at vi allerede er godt rustet ettersom fagfeltet aldri har vært så preppet med forskning som i 2020, samtidig som kritikken av «ledelse» som paraplybegrep i mange tilfeller er både nødvendig og berettiget (Gaure \& Nævdal, 2018; Tangen, 2020). Like fullt er det mange ledere her til lands, med til dels ulik filosofi, atferd og skolering. Nettopp derfor er det behov for et mer nøkternt blikk på hvordan lederskap utøves og kan forbedres i det nye arbeidslivet. I det følgende vil vi vise hvordan kapitlene forenes langs noen arbeidslivsdimensjoner i utforskningen av ledelse i det nye arbeidslivet.

\section{Fire dimensjoner som forener kapitlene}

For det første viser kapitlene at ledelse handler om mennesker mer enn prosesser eller bedrifter. I 1999 skrev psykiater Edward Hallowell i Harvard Business Review om en urovekkende trend blant sine pasienter som kom på grunn av trøbbel i arbeidslivet: erosjonen av møter mellom mennesker. Oppmerksom, menneskelig kontakt var ifølge Hallowell en truet kommunikasjonsform, intet mindre. Motsatsen er å se ansatte og hverandre som skapninger av kjøtt og blod, og selv om foreløpige undersøkelser viser at det å jobbe hjemmefra er vel så effektivt som tilstedeværelse 
på et felleskontor, ${ }^{2}$ er det mye som tyder på at arbeidslivets fellesskap kan ha positive ringvirkninger på andre måter. I kapittel 2 undersøker Rune Bjerke med forskjellige caser (blant annet Gjensidige og Findus) hvordan arbeidsgivere kan bidra til bedre folkehelse. Årsaken er at mange helseproblemer, som gjerne ender i sykefravær, stress og tapte årsverk, har opphav i arbeidslivets organisering, ledelse og kultur. Derfor tar Bjerke til orde for en «sunn prestasjonskultur» som motgift mot arbeidslivsrelaterte helseplager. Ansatte som sosiale vesener er videre en viktig motvekt til forkjempere for digitaliseringsprosesser som med glad stemme og kullsviertro på nye muligheter glemmer å ta høyde for de mellommenneskelige konsekvensene av dem (Royakkers, Timmer, Kool \& van Est, 2018). Kapittel 10 av Anne Haugen Gausdal og Birthe Kåfjord Lange viser at tillit påvirker implementeringen av ny teknologi. Teknologi anbefaler seg ikke selv, den må forankres og forklares på måter som gjør at de ansatte får eierskap til hva den skal brukes til. Dersom innføring av teknologi oppfattes som legitim av dem endringene omfatter, vil det være mindre friksjon underveis. Dette med eierskap til egen utvikling er også sentralt i kapittel 3 av Irmelin Drake, der en rikere forståelse av selvledelse - eller endog superledelse - i kunnskapsintensive organisasjoner kan motvirke det Drake kaller «honningfellen»: en arbeidssituasjon der ansvaret for egen framdrift blir så altomfattende at friheten med å være selvdreven blir en byrde. Ettersom det samtidig ofte ligger en forventning i virksomheter om å bidra til medarbeiderskapets ånd, blir det å regulere egen arbeidshverdag en tosidig nødvendighet for den enkelte. Selv om det å si NEI ofte er den enkleste veien ut av denne problematikken (Brinkmann, 2016), redegjør Drake for andre og mer løsningsorienterte måter å skape en bærekraftig arbeidshverdag på.

2 For noen eksempler, se: Transportøkonomisk institutt (TØI), FAFO, Kantar TNS og andre gjør p.t. undersøkelser av dette, og har publisert noen foreløpige funn: «Fortsatt mange på hjemmekontor etter gjenåpningen», TØI, 3. juli 2020. Hentet fra https://www.toi.no/forskningsomrader/reisevaner/fortsatt-mange-pa-hjemmekontor-etter-gjenapningen-article36348-213. html; «Redusert effektivitet med hjemmekontor»,26. mars 2020. Hentet fra https://kantar.no/ kantar-tns-innsikt/redusert-effektivitet-med-hjemmekontor/; «Hjemmekontor og digitale løsninger», fafo.no, april 2020. Hentet fra https://www.fafo.no/images/pub/2020/300420-hjemmekontor-faktaflak.pdf 
For det andre avdekker kapitlene at menneskers handlingsrom, enten dette er strategisk eller taktisk, oppfattet eller formelt, har avgjørende betydning for lederatferd. Selve begrepet strategisk handlingsrom blir diskutert i kapittel 4 av Jarle Bastesen og Birthe Kåfjord Lange. Basert på en studie av 10 logistikkselskaper der alle har store utfordringer knyttet til digitalisering og omstilling, viser de at det ikke nødvendigvis er størrelsen på lederes handlingsrom som er det viktigste, men om ledergruppen faktisk er oppmerksomme på strategisk relevante alternativer når de skal utforske framtidige utfordringer. I kapittel 5 viser Andreas N. Thon og Thea Berg at ledelse kan ses som en organisasjonsprosess, hvor en i større bedrifter når målene sine fordi ledere har tilstrekkelig handlingsrom til å håndtere uforutsette hendelser i daglig drift. Virksomheter i vår tid tvinges til å løfte blikket fra fokus på indre effektivitet og produktivitet, til å ta hensyn til omgivelser preget av kompleksitet, uforutsigbarhet og til dels kaos. Ved å adoptere ledelsesprinsipper fra militær virksomhet viser Thon videre hvordan organisasjonen er tjent med å la teamene få tillit til å fatte beslutninger basert på overordnede intensjoner og lokal situasjonsforståelse. En annen måte å se dette på er å gå via «nye» tilknytningsformer i arbeidslivet. Kapittel 6 av Jarle Bastesen og Elin Ørjasæter viser at ledere ofte er helt avhengig av å kunne leie inn IT-konsulenter med spisskompetanse for å få gjennomført krevende prosjekter og/eller få til en digital transformasjon av virksomheten. Selv om lederne ofte opplever at konsulentene er helt nødvendige for å få utført jobben, blir mange ledere også fanget i løsninger hvor de mister sin langsiktige strategiske styring til konsulentene og konsulenthusene. Hans Erik Næss og Rune Bjerkes studien av eventledelse i kapittel 7 utgjør et tredje bidrag som viser verdien av å identifisere et strategisk handlingsrom før endringsprosesser eller prosjekter iverksettes. Casen viser at tillit til arrangørene av et racingløp i Zürich by ikke kom automatisk. For å få gehør hos byborgere, sponsorer og myndigheter måtte tilliten skapes gjennom innovative former for samskaping. Det viste seg at løfter om framtidige inntekter til byen og bedre miljøimage ikke var nok. Denne samskapingen krevde i stedet kulturell kompetanse om hva beboerne, som ble omfattet av et slikt event, følte at de fikk igjen for ulempene det var ved å få eventet organisert rett utenfor døra. Beboerne 
måtte inkluderes i planleggingen av eventet på en annen måte enn som potensielle kunder.

For det tredje støtter kapitlene opp under påstanden om at ledelse er et kontekstsensitivt gjøremål. Det vil si at hvis ledelse kan sies å være en del av sosiale strukturer, verdier og kulturer, kan det heller ikke skilles fra de nære omstendighetene der den utøves (Oc, 2018). Samtidig er det ikke slik at bare ingeniører kan lede Equinor, for å sette det på spissen. Det er både mellommenneskelige og virksomhetsmessige grunner til å aktivt balansere samfunnsansvar, verdier og fagekspertise i organisasjonen (Christie, 2014). I kapittel 8 undersøker Birthe Kåfjord Lange og Hans Erik Næss hvorvidt et mentorprogram for unge idrettsledere ruster deltagerne til morgendagens utfordringer i Idretts-Norge. Kapitlet avdekker en del utfordringer med å tilpasse ledelsesprinsipper fra næringslivet og mentorprogrammer i sin alminnelighet til idrettens hverdag. Samtidig avdekket studien at deltagerne spesielt så på aktuelle lederegenskaper i idretten som lite bundet av idrettens organisatoriske særegenheter, og framhevet i stedet mulighetene for at en miks av perspektiver ga idretten friskt blod og kapasitet til å tenke nytt. For å ivareta energien i denne spenningen, i stedet for at den blir en trussel, må norske idrettsorganisasjoner tenke nytt om forholdet mellom tradisjon og innovasjon. En beslektet innfallsvinkel til å forstå kontekstens betydning tilbys av Mari Svendsen og Ola Martin Jensen Larsen, som i kapittel 9 belyser hvordan organisasjonene kan utvikle allerede eksisterende elementer i organisasjonen som følge av arbeidsinkludering. Ved å konseptualisere hvordan arbeidsinkludering kan bidra til organisasjonsutvikling på tvers av organisatoriske nivåer, viser kapitlet til organisatoriske effekter av arbeidsinkludering i stedet for å legge vekt på hvor godt inkludert den enkelte arbeidstaker blir. Argumentet er at dette vil gi organisasjoner et større incentiv til å ta i bruk en strategi som sikrer økt sosial bærekraft, samtidig som det skaper en mer robust og konkurransedyktig organisasjon.

For det fjerde berører kapitlene spenninger mellom endring og kontinuitet. Til tross for påstander om at endring er normalen og fornyelse er det som gjør at virksomheter overlever, er det likevel sterke krefter i sving når historie og erfaringer skal videreføres $\mathrm{i}$ «den nye organisasjonen». I Arbeiderkollektivet, Sverre Lysgaards studie fra 1950-tallet av en norsk bedrift i Moss (Lysgaard, 1961/2003), oppdaget han at arbeiderne 
var preget av samhold gjennom et sinnrikt normsystem for hva som er akseptabel atferd og passe opposisjon. Ledelsen, derimot, var teknisk orientert og kvantitativt maksimerende. Da en gruppe forskere gjenskapte studien i den samme bedriften på begynnelsen av 200o-tallet, var ikke endringene så store. Samtidig var den moderne bedriften mer kompleks på en annen måte enn forventet med tanke på hvor ansattes lojalitet lå på grunn av sosiale relasjoner. Ingeniørene, for eksempel, kunne høre til hos både ledelse og arbeidere (Axelsson, Karlsson \& Skorstad, 2016). Slike spørsmål om endring, lojalitet og verdier er relevante i lys av kapittel 1. Der analyserer Nils Arne Bakke og Jens Barland hvordan en ny type AI-agenter overtar et økende antall og skaper nye arbeidsprosesser og beslutningstyper, hvor de både lærer raskere og overgår menneskers evner til å ta kompetente avgjørelser. Kapitlet viser hvordan denne type digital transformasjon gjør det mulig for ledere i Amedia å skape et journalistisk produkt som bedre lever opp til virksomhetens offisielle publiseringsidealer. Endelig berører temaet endring og kontinuitet spørsmålet «Hva gjør så mange ledere ineffektive?» I kapittel 11 tar Helene Tronstad Moe utgangspunkt i blant annet nevrovitenskap for å identifisere barrierer for effektivt lederskap. Hun viser at hormonforskjeller mellom kvinner og menn er med på å forklare lederatferd knyttet til maktforhold, stressmestring, samarbeidsevner og beslutningstagning. Kapitlet gir med det en fornyet forståelse av samspillet mellom biologiske og sosiale faktorer, og viser behovet for en mer sammensatt forståelse av hvorfor ledere gjør som de gjør - og hvorfor de ikke gjør som de burde gjøre.

\section{Avsluttende bemerkninger}

I sum byr altså boka på et knippe forskningsstudier av ledelsesrelaterte problemstillinger som tjener en dobbel hensikt. På den ene siden utforsker kapitlene temaer, caser og begreper som bringer forskningsfeltet framover, spesielt i norsk sammenheng, med et mangfold av teoretiske, konseptuelle og empiriske studier. På den andre siden utfordrer de samme kapitlene en del antagelser, språkbruk og påstander innen ledelsesforskning som kan bidra til å tilsløre fagets verdi for arbeidslivet generelt. Vår ambisjon er naturligvis ikke å dekke alle felter innen ledelses- og 
organisasjonsforskning, eller å besvare alle aktuelle spørsmål. Målet med boka er å presentere et utvalg med relevante forskningsfunn i ledelse- og organisasjonsfag, som på hvert på sitt vis berører fire sentrale dimensjoner ved forskningsfeltet. Da dette er en vitenskapelig antologi, er kapitlene rike på forskningsbaserte innsikter i hva slags omstendigheter og prosesser morgendagens ledere vil ha nytte av å kjenne til. Boka retter seg derfor primært til forskere og lederutviklere, men også til studenter og praktikere med interesse for ledelse som fag.

\section{Referanser}

Axelsson, J., Karlsson, J. C. H. \& Skorstad, E. J. (2016). Arbeiderkollektivet i dag: replikasjon og teoretisk utvikling. Tidsskrift for samfunnsforskning, 57(2), 105-134. https://doi.org/10.18261/issn.1504-291X-2016-02-01

Bungum, B., Forseth, U. \& Kvande, E. (Red.). (2015). Den norske modellen. Internasjonalisering som utfordring og vitalisering. Bergen: Fagbokforlaget.

Brenna, L. \& Solheim, M. C. W. (2018). Hvordan lede mangfold? Praktisk økonomi \& finans, 3(34), 186-195. https://doi.org/10.18261/issn.1504-2871-2018-03-03

Brinkmann, S. (2016). Stå imot - si nei til selvutviklingen. Oslo: Forlaget Press.

Christie, W. (2014). Politikk og fag - på samme lag? Helseledelse fra teknokrati til velferdsdannelse. I G. Botten, J. Frich, T. P. Hagen, T. Iversen \& H. Nordby (Red.), Helsetjenestens nye logikk. Bergen: Fagbokforlaget.

Dølvik, J. E. \& Steen, J. R. (2019). Drivkrefter og utfordringer for den norske modellen. Framtidens arbeidsliv: notat 2 (FAFO-notat 2019:15). Hentet fra https://www.fafo. no/images/pub/2019/10305.pdf

Gaure, S. \& Nævdal, E. (2018, 8. februar). Fagfolk må lede fagfolk. Aftenposten. Hentet fra https://www.aftenposten.no/meninger/kronikk/i/zL7A5v/fagfolk-maalede-fagfolk-simen-gaure-og-eric-naevdal

Hallowell, E. (1999). The human moment at work. Harvard Business Review, 77(1), 58-66. Hentet fra https://hbr.org/1999/o1/the-human-moment-at-work

Hammer, C. \& Falkman, Å. (2018). Future professional life. A vision of a sustainable working life 3.o. Hammer \& Hanborg. Hentet fra https://issuu.com/ susannaavander/docs/future_professional_life_3_enkelsid

Harris, L. C. \& Ogbonna, T. (2002). The unintended consequences of culture interventions: A study of unexpected outcomes. British Journal of Management, 13(1), 31-49. https://doi.org/10.1111/1467-8551.00221

Iansati, M. \& Lakhtani, K. R. (2019). Competing in the age of AI: Strategy and leadership when algorithms and networks run the world. Boston, MA: Harvard Business Review Press. 
Klingler-Vidra, R. (2019). Global review of diversity and inclusion in business innovation. London: LSE Consulting, London School of Economics.

Kirton, G. (2020). Diversity and inclusion in a changing world of work. I A. Wilkinson \& M. Barry (Red.), The future of work and employment (s. 49-64). Cheltenham: Edward Elgar Publishing.

Lier, A. (2017, 5. juli). Slik kan toppledere akselerere det nye Norge. E24. Hentet fra https://e24.no/naeringsliv/i/8wdXbG/det-nye-norge-kommentar-av-anders-lierslik-kan-toppledere-akselerere-det-nye-norge

Lysgaard, S. (1961/2001). Arbeiderkollektivet. En studie i de underordnedes sosiologi. Oslo: Universitetsforlaget.

Mazur, B. (2014). Building diverse and inclusive organizational culture-best practices: A case study of Cisco Co. Journal of Intercultural Management, 6(4), 169-179. https://doi.org/10.2478/joim-2014-0043

McAfee, A. \& Brynjolfsson, E. (2017). Machine. Platform. Crowd. New York: Norton \& Company.

McCord, P. (2018). Powerful: Building a culture of freedom and responsibility. San Francisco, CA: Silicon Guild.

McLuhan, M. \& Leonard, G. (1967, 21. februar). The future of education: The class of 1989. LOOK Magazine, 23-25.

Nanterme, P. (2018, 17. juli). Why our 'culture of cultures' is a true, strategic differentiator. Accenture.com. Hentet fra https://www.accenture.com/us-en/blogs/ blogs-culture-true-strategic-differentiator

Oc, B. (2018). Contextual leadership: A systematic review of how contextual factors shape leadership and its outcomes. Leadership Quarterly, 29(1), 218-235. https://doi.org/10.1016/j.leaqua.2017.12.004

Pless, N. M. \& Maak, T. (2004). Building an inclusive diversity culture: Principles, processes and practice. Journal of Business Ethics, 54(2), 129-147. https://doi. org/10.1007/s10551-004-9465-8

Rivera, L. A. (2012). Hiring as cultural matching: The case of elite professional service firms. American Sociological Review, 77(6), 999-1022. https://doi.org/ $10.1177 / 0003122412463213$

Rosa, H. (2013). Social acceleration: A new theory of modernity. New York: Columbia University Press.

Royakkers, L., Timmer, J., Kool, L. \& van Est, R. (2018). Societal and ethical issues of digitization. Ethics and Information Technology, 20, 127-148. https://doi.org/ 10.1007/s10676-018-9452-X

Tangen, K.-F. (2020, 12. mai). Kringsatt av ledelse. Manifest tidsskrift. Hentet fra https://www.manifesttidsskrift.no/kringsatt-av-ledelse/

Wyndow, P., Li, J. \& Mattes, E. (2013). Female empowerment as a core driver of democratic development: A dynamic panel model from 1980 to 2005. World Development, 52, 34-54. https://doi.org/10.1016/j.worlddev.2013.06.004 


\title{
Business Model Transformation of Legacy Newspapers in The Age of The Digital Attention Economy
}

\author{
Nils Arne Bakke \\ Kristiania University College \\ Jens Barland \\ Kristiania University College
}

\section{Arild Fetveit}

Aletheia Media

\begin{abstract}
This chapter explores ways in which legacy newspapers may transform their business and operational models to ensure profitability and protect journalistic ideals. This transformation is explored through the lens of Norwegian media company Amedia, an early innovator. Our analysis sheds light on the ways in which the industry has come to understand the digital attention economy as defined through key innovations initiated by Google and Facebook. At Amedia, these innovations paved the way for a major corporate turnaround in which data harvesting and AI play major roles. The turnaround is still ongoing after seven years, but preliminary conclusions can be drawn. Within an ecological view of organizational adaption, this chapter proposes six theses about design requirements and transformation for legacy newspapers and concludes with four key findings: a) survivability will be difficult without the implementation of a new AI-operational model and business model built on software, b) a space is emerging that supports profitable quality journalism with strong commitments to veracity and fairness, c) most outlets still need advertising revenue to achieve profitability, and d) roles and skill-sets of top managers and journalists are undergoing major changes.
\end{abstract}

Keywords: digitalization, the attention economy, AI, journalism, newspaper business models \& A. N. Thon (Red.), Ledelse av mennesker $i$ det nye arbeidslivet (Kap. 1, s. 19-52). Oslo: Cappelen Damm Akademisk. https://doi.org/10.23865/noasp.118.ch1

Lisens: CC-BY 4.o. 


\section{Introduction}

\section{Topic and research question}

Since the start of the millennium, newspapers have been exposed to new competitive pressures shaped by the evolving digital attention economy, resulting in losses of readership, subscriptions, and advertising revenue. In spite of numerous smaller innovations, the downward spiral continued until 2013-2015, when management across the industry started to develop a better understanding of this new environment and began to develop viable strategies for moving forward in this new more competitive environment.

Amedia, Norway's largest publisher of local newspapers, offers a window into the development of one of these strategies. Along with a considerable number of newspaper publishers, they now find themselves in what we believe are the early days of a more fundamental crossindustry shift towards organizations built on AI and software, as opposed to being built predominantly on humans (Iansiti \& Lakhani, 2019; McAfee \& Brynljolfsson, 2017). This shift defines the broader managerial and leadership challenges Amedia has faced over the last seven years, and it is likely to keep defining them while new aspects of the strategy are implemented and optimized. Amedia therefore provides a productive case for exploring the ways in which business models for legacy newspapers may successfully be adapted to a media ecology defined by the digital attention economy.

In this chapter, we draw on the Amedia case in order to explore more specificially how legacy newspapers may digitally transform their business and operational models in ways that can retain profitability and protect journalistic ideals. ${ }^{1}$ We also go beyond the Amedia case to stipulate key aspects of what appears to be an emergent business model for newspapers internationally (Piechota \& Brock, 2019; Villi \& Picard 2018),

$1 \quad$ By journalistic ideals we refer to the principles developed by journalists and publishers over years and articulated in various codes of ethics. Examples can be found in the "Code of Ethics of the Norwegian Press" and in "The Society of Professional Journalists' Code of Ethics." The latter can be condensed in the following four principles: Seek truth and report it. Minimize harm. Serve the public. Be accountable and transparent. 
we will propose six theses about challenges related to business model design and transformation, and finally, we will probe how the leadership of Amedia has responded to these issues in an in-depth case study analysis.

\section{Background and industrial context}

Until about 2013, newspapers typically adapted to the rapidly changing digital media ecology with a strategy of piecemeal innovation by trial and error. Due to continuous publishing in compressed news cycles cycles, this strategy may be well-fitted to news media. Over time, significant strategic changes may be achieved even if each step is modest (Barland, 2012; Storsul \& Krumsvik, 2013). However, after more than a decade of the new millennium had passed, alternating between digital experiments, small-step changes and recurrent rounds of downsizing, the situation still looked dire.

The newspaper industry had not grasped the disruptive potential of the new AI- and software-driven businesses of the digital attention economy represented by Google, somewhat later also by Facebook, and in 2011-12, Netflix (Fogg, 2003; Wu, 2016; Zuboff, 2019). The core elements of this new business model, invented by Google between 2001-2003, grew Google's profitability about 3500\% over three years (Zuboff, 2019, p. 74-80). Constitutive of the model was the merger of behavioral psychology, AI, and machine learning technology embedded in software algorithms based on a disguised and manipulative two-way communication with end-users. This enabled a quantum leap in capabilities of predicting and modifying behavior, making their products vastly superior within advertising, marketing, and sales. The key logic of their business model, which can be considered constitutive of the digital attention economy, was neither understood nor successfully dealt with by significant media outlets until about ten years after its inception. Confronted with these strategic disruptions from the digital attention economy, the responses from the management of most legacy newspapers were tactical, which spared them the pain of challenging the fundamental tenets of how they conceptualized their businesses (Brunsson, 1985; Christensen, 
McDonald, Altman \& Palmer, 2018; Christensen, Raynor \& McDonald, 2015).

In 2014, a strategy document leaked from The New York Times captured the situation for the newspaper industry well. It revealed an organization in deep crisis and disarray, struggling to understand and adapt to the competitive pressures of the digital attention economy. In spite of numerous initiatives, experiments, and smaller innovations, their leadership lacked a clear diagnosis. Key business parameters were in rapid decline (Benton, 2014; New York Times, 2014, 2017).

Amedia shares important commonalities with The New York Times. By the end of 2015, Amedia had terminated its viral site Buzzit. Even if the site was among the most shared on social media in Norway, earnings proved dismal. ${ }^{2}$ The viral approach failed internationally. The approach achieved at best modest success in outlets like BuzzFeed and Huffington Post. It fell quite short of delivering the profitability of news businesses that fully exploited the potentials of the digital attention economy ( $\mathrm{Wu}$, 2016). Realizing the inadequacy of click-bait, a conclusion that Google had come to ten years earlier, can be seen as a starting point for a revision of Amedia's digital strategy. This realization led to a fundamental transformation of leadership and journalistic approach along with the development of an AI-operational model based on key elements of approaches championed by Google and Facebook.

\section{The structure of the argument}

The chapter proceeds by outlining the research strategy and case study approach on which it is based. Thereafter, we account for the theoretical framework of the study, from which we derive four theses about viable business models for legacy news, and two theses related to the digital transformation of legacy news. We then probe how Amedia navigates these challenges, as well as the ways in which the case fits our theoretical framework, focusing especially on:

2 There was still optimism in 2013-14: "We believe we can do it. The possibilities of the Internet have no limits, says the editor of Nordlys, Anders Opdahl.” https://www.amedia.no/arkiv/buzzit/ 
- Business model, operational model and profitability

- Retaining journalistic ideals, management of brand identity and trust

- Leadership, culture, and transformation

Finally, by probing the theoretical framework against the Amedia case, we explore steps towards analytical generalization (Yin, 2017), which we summarize together with suggestions for further research in the conclusion.

\section{Research Strategy and Case Study Approach}

Our research strategy follows the logic of a theoretically informed case study (Yin, 2017). We based the case study on interviews with key individuals within Amedia, internal and public documents, as well as access behind the paywall to the digital editions of all the 80 newspapers of the Amedia Group. ${ }^{3}$ Our team interviewed senior editiorial and business managers of the Schibsted Group, and we gathered material from primary and secondary sources from a variety of other news organizations. The theoretical framework we draw on is interdisciplinary. It combines several subfields within management sciences like business model analysis, economics, organizational theory and leadership, and recent theorizing related to digital business models and organizations built on software and AI. Figure 1 depicts the research strategy and how it relates to the theoretical framework. Development (PN), Chief Journalistic Product Officer (JØL), Chief AI and Machine Learning Officer (HS), Chief Editor of a successful outlet (GJ) and Director of Advertising (CT). We had follow-up interviews by phone (15-45 minutes) and extensive email correspondence with the interviewees. As part of a parallell case study in the Schibsted Media Group, we conducted two interviews with two top managers in the Schibsted Media Group (of approximately two hours each). Additionally, we had several conversations, written exchanges, and discussions with the former Group Head of the Schibsted local newspapers division (SR) (approximately 10 hours). We had access to relevant internal and external presentations and used a wide array of public sources like newspaper articles and annual reports. 
Case study logic - Amedia Group

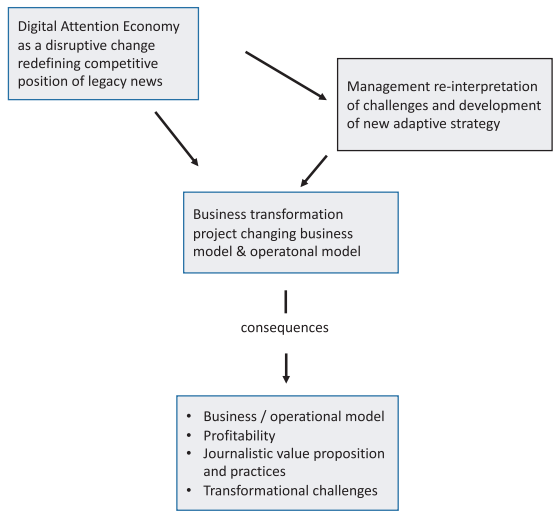

Theoretical Framework

4 theses concerning viable business models \& operational models for legacy media 2 theses concerning management change and transformation of legacy media

Figure 1 Research strategy and approach to research questions

\section{Theoretical Framework}

\section{Key features of the digital attention economy relevant to news media}

The digital attention economy and legacy newspapers: A basic premise of our analysis of the digital attention economy in this section is an ecological view on organizational adaptation, where individual organizations are subject to selection pressures to which they must respond adequately in order to survive. This points to design requirements that need to be recognized and acted upon by management for an organization to remain in business (Baum \& Rao, 2004; Groth, 1999; Lewin, Weigelt \& Emery, 2004).

The generic logic of digital products and services: There are significant differences between products and services which at their core consist of information and therefore are almost fully susceptible to digitization (e.g. news, films, music), as opposed to those that, due to their very nature, cannot escape the limitations of the physical world (e.g. cars, accommodation, wine). Although paper editions still deliver significant revenue for some newspapers, it is uncontroversial to assume that, possibly with niche exceptions, paper will eventually disappear from the news business. Thus, our focus is first and foremost on news as a fully digitized product, with digitized 
distribution and end-user consumption. Such products are equipped with five notable qualities that decisively impact viable business models:

- Zero marginal cost-Once a newspaper is digitized, making a second copy and distributing it globally is essentially free.

- Perfect quality of copies-Once a digital original is created, further copies are, in principle, as good as the original.

- Instant global availability -When the digital copy is available on a device attached to the Internet, distribution in unlimited numbers to anywhere in the world is possible within a fraction of a second.

- Traceability - Through IoT technology, the consumption of a digitized service (i.e. music, video, newspaper articles), is traceable to an individual through a wide set of proxies like the device ID, the subscription service the user may be logged onto, software trackers installed on the user's device, GPS trackers etc. Because users tend to be "always on," service providers may track and record usage in real time. When the user consumes the product, the supplier "consumes" the user by harvesting their attention and an array of associated behavioral and contextual data. ${ }^{4}$

- Scalability of volume and scope-Due to zero marginal cost, digital products have close to unlimited volume scalability. By implementing AI, organizations scale better in scope, and handle complexity at a lower cost. AI agents that communicate with each other exchange information and negotiate decisions may replace human agents. Such AI factories featuring tightly woven AI agents collect and process virtually unlimited quantities of data, enable increased speed and quality of decisions, and reduce transaction cost. Bottlenecks, rooted in the poor scalability of human cognitive skills, disappear because the marginal cost of serving an additional user by digital AI agents is negligible (Iansiti \& Lakhani, 2019). ${ }^{5}$

4 A photograph submitted by a user, for example, involves both a behavioral act and contextual metadata about time and place, as well as information that can be processed by AI to identify buildings, streets, individuals etc.

5 Brynjolfsson (Brynjolfsson, Mitchell \& Rock, 2018) estimate that half of current work activities performed by humans are replaceable by AI: "the impact will reach across virtually all occupations transforming every job regardless of income level and specialization." 
These five qualities are highly relevant for the scaling of digital journalism. However, whereas music and film may be considered to result from one-off production efforts with an economic lifetime of years, the news has a primary lifetime of hours or, at best, weeks. Thus, even if journalism scales better by means of AI tools, and some categories of journalism can be partly or fully automatized, there are limits to its scaleability. The non-standardized character and short economic lifespan of thoroughly researched news provides restrictions. Still, AI capabilities may support fairly complex journalistic work and transform journalism into an AI-enabled enterprise. Advertising - the main source of income for legacy newspapers beyond journalism-scales better. A digitized newspaper may build a profitable advertising business by offering access to its own "walled garden" featuring unique data from its users. In order to achieve this, three conditions must be fulfilled. First, the brand of the journalistic operation needs to be sufficiently strong. Second, data volumes need to be sufficient to support AI and machine learning. Third, the demographic composition of the readership must be sufficiently attractive for advertisers.

\section{Key features of the digital attention economy and consequences for news media}

The five qualities of the digital economy described above have enabled a new breed of platform businesses to emerge, operating according to an economic logic termed the "Attention Economy" (Bueno, 2017; Fogg, 2003; Goldhaber, 1997; McNamee, 2019; Simon, 1971; Zuboff, 2019).

A key characteristic of the digital economy writ large, is an abundance of information, and a subsequent information overload. As Herbert A. Simon, succinctly put it: "the wealth of information means a dearth of something else: a scarcity of whatever it is that information consumes. What information consumes is rather obvious: it consumes the attention of its recipients. Hence a wealth of information creates a poverty of attention" (Simon, 1971, p. 40). The abundance of information also comes with a flood of deceptions, which makes the vetting of its reliability crucial. Journalism, from initially being a scarcity-of-information 
game, is transformed in the wake of these developments into a scarcityof-attention-and-truth game.

The key value driver for Facebook, Google, Twitter and others like them is their ability to predict and stimulate behavior. These capabilities are based on an array of manipulative techniques informed by the behavioral sciences, merged with software development skills and AI, inspired by B. J. Fogg's conception of "persuasive technology." The basic idea is that computers, by utilizing insights from behavioral sciences and rhetoric, may act like human proxies to predict and influence behavior in scalable ways that human-to-human interaction never can (Fogg, 2003, p. 1-21).

For newspapers, the digital attention economy raises multiple challenges. We highlight four. First, a shared digital battleground, where businesses are fiercly competing 24/7/365 for the finite resource of attention, replaces a pre-digital world where cumbersome distribution of paper editions made competition both in journalism and advertising less fierce, even close to absent in areas where a single newspaper could exploit a privileged position. ${ }^{6}$ Second, in the competition for attention, platforms like those of Google, Facebook, and Twitter have the advantage of being less constrained by demands regarding content veracity, allowing them to apply a wider set of tools. As revelations of internal discussions inside Facebook leaderhip indicate, platforms with only marginal curatorial responsibilities may actually benefit commercially by allowing an abundance of conspiracy theories, fake news, and conflict-driven conversations to circulate (Horwitz \& Seetharaman, 2020; Vosoughi, Roy \& Aral, 2018).7 Third, because ambitious news production is only moderately scalable, news media suffer a competitive disadvantage because the platforms rely on content models scaling significantly better. The platforms

6 This was pointed out by (SR), and also by Warren Buffett (Buffett, 1997, p. 61), "When Charlie and I were young, the newspaper business was as easy a way to make huge returns as existed in America. And one not-too-bright publisher once said 'I owe my fortune to two great American institutions: monopoly and nepotism.' No paper in a one-paper city, however bad the product or however inept the management, could avoid gushing profits."”

$7 \quad$ Horowitz and Seetharama, WSJ (2020): "Our algorithms exploit the human brain's attraction to divisiveness, and if left unchecked, Facebook will feed users with more and more divisive content in an effort to gain user attention and increase time on the platform." 
rely both on indefinitely scalable free content production shared by users, and the circulation of free or discounted content from news media and other types of content like film, music, and literature. ${ }^{8}$ Fourth, the prevalence of finite organizational capacities to collect, process, and convert the growing abundance of information into journalistic products within short news cycles, in compliance with high epistemological standards of veracity, is an uphill fight against cognitive overload for newspapers (Cyert \& March, 1992; Forrester, 1989; Kahneman, 2012, March \& Simon, 1993; Silverman, 2019).

These challenges force management in the newspaper industry to rethink their business and operational models. They make replacing human-driven operational models with scalable AI-driven models appealing as long as it does not compromise product quality.

\section{Business models available to news media in the Digital Attention Economy}

Businesses rely on models that constitute the rationale of how an organization defines, creates, delivers, and captures value (Osterwalder \& Pigneur, 2010). ${ }^{9}$ Iansiti and Lakhani break the concept down into two parts. They define business model narrowly as "the way the firm promises to create and capture value" (a conception which is interchangeable with Osterwalder's value proposition), and add to this, operating model, which they define as the way the firm delivers value to its customers (Iansiti \& Lakhani, 2019, p. 26-27).

Platforms constitute networked ecologies expanding across industries, as opposed to "pipe models" and "vertical hierarchies," which tend to keep industries largely insulated from each other (Choudary, 2015; Iansiti \& Lakhani, 2019; Williamson \& Winter, 1993). The platform model of the digital attention economy, as exemplified by Google and Facebook,

8 The Facebook Journalism Project aims to improve news quality and facilitate a fairer share of revenue with news media. See interview with Facebook executive Jesper Doub, former editor of Spiegel Online. https://journalisten.no/facebook-jesper-doub-sosiale-medier/amerikanskavis-facebook-er-villig-til-a-betale-for-nyheter/372580

Pettersen and Krumsvik (2019), illustrate a productive analysis of news media based on the Osterwalder framework. 
qualifies as a "cross industry" - a disruptive innovation that fundamentally reshapes competitive parameters in several industries, including that of newspapers (Christensen et al., 2015, 2018). We propose to distinguish between two subsets of the model, with different value propositions and revenue models.

1) The Google-Facebook-Fogg model: Google and Facebook are multisided platforms, with different value propositions for each user group (Choudary, 2015). The platforms tend to describe their value propositions for free end-use in highly positive terms. Facebook, for example, claims to be "connecting and maintaining relationships" and even "saving democracy" (Zuckerberg, 2020). Commercially they use behavioral technologies to usurp the behavioral surplus of user engagement for the purpose of manufacturing products aimed at prediction and modification of behavior to be sold to third parties (Fogg, 2003; McNamee, 2019; Ray, 2011; Zuboff, 2019).

These platforms are important distribution channels for news, but are not in themselves journalistic enterprises. As we have noted, their utility function makes them largely agnostic, even nihilistic, in relation to the veracity of content. Facebook management recently discussed modifying algorithms in order to improve the veracity and quality of the content circulating on their platform, but decided against it due to worries related to reduced engagement and falling revenue (Horowitz \& Seetharama, 2020). Obviously, this is problematic for news outlets commited to veracity.

2) The Netflix-Fogg model was launched as a strategic bet by Netflix in 2011-12. The main idea, in the words of Netflix, was to "put the viewer in control of the experience." ${ }^{\circ}$ Netflix rediscovered a lost trove of human capacity for long-term focused attention. Media analytic Grant McCracken commented: "TV viewers are no longer zoning out as a way to forget about their day, they are tuning in ...” (D’Souza, 2020). Bingewatching, keeping viewers locked-in, often consuming a whole series

10 Since 2011-12, this has been a general philosophy, succinctly illustrated by the interactive film Bandersnatch (Rubin 2020). 
of 13 episodes over a weekend, stood the attention tool-box on its head. Attention capture was achieved by content meant to keep people focused over longer time spans, rather than the distractive behavioral stimulusresponse framework utilized by Google-Facebook-Fogg. Netflix innovated by applying the toolbox of the digital attention economy for content improvement, by minutely analyzing viewing patterns and building personalized profiles by means of AI and machine learning. The key objectives of data harvesting were to optimize recommendations based on personalized profiles and to improve Netflix's understanding of preferences as guidelines for investing in new content $(\mathrm{Wu}, 2016) .{ }^{11}$ The revenue model was entirely subscription based. Advertising was banned.

The two subsets of the digital attention economy model imbue opposed incentives related to content and revenue. News media now increasingly make a choice between the two models, or combine them. Whereas the underlying logic of the Google-Facebook-Fogg model fosters epistemological agnosticism, nihilism, or pure instrumentalism, the Netflix-Fogg model may also effectively support ambitious journalistic ideals.

\section{Four theses on viable business models for legacy news}

Based on the logic of the digital attention economy as laid out, we propose four theses about viable business models for news media. They aim to highlight strategic options and design choices that managers in these outlets must deal with.

1. Commitment to veracity may become a more potent value proposition for newspapers. Abundance of information and disinformation create demand for guardians of veracity and actionable knowledge, making such capacities a powerful value proposition, especially for business news. News media with strong ideological commitments and partisan epistemological approaches may

11 With a budget of 15 billion USD, Netflix is the biggest creator of quality content in the film industry. 
attract large numbers of customers who feel comfortable within echo chambers. However, such a strategy is likely to hamper trust beyond the dedicated members of the in-group. When partisan epistemology leads to socially constructed realities in conflict with objective realities existing outside those constructions, the results might even be deadly (Bursztyn, Rao, Roth \& Yanagizawa-Drott, 2020). The New York Times and Der Spiegel, who have built their brands on a commitment to objectivity and balanced reporting, recently experienced internal uproars by journalists revolting against objectivity as previously operationalized in the press. They raised the demand that "moral clarity" become part of the journalistic value proposition. ${ }^{12}$ However, there are limits in the marketplace to strategies that come across as partisan, which is why such actions threaten to undermine the credibility of these outlets (Bursztyn et al., 2020).

2. Deploying aspects of the Netflix-Fogg model increases the chances of surviving in the marketplace. The Netflix-Fogg model may create productive interaction between journalists and users, increase relevance and perceived quality, and foster a willingness to pay for news media. The model creates learning opportunities for journalists by allowing them to better understand what is deemed relevant by their readers, as well as how to tell stories that engage them. By enabling two-way communication facilitated through AI software, the model helps journalists become more in tune with their readers and incentivizes them to avoid a paternalistic and moralizing approach. This may mitigate the increased business risk implied by the fact that legacy newspapers largely have lost control of the public sphere, which suggests that arrogance might be punished by the readers in ways not conceivable in the pre-digital age. similar debate within New York Times (Edelmann, 2020; Sullivan, 2020; Welch, 2020). As part of this debate, The New York Times has been heavily critized for their 1619 Project by several renowned historians in the field (Stephens, 2020). 
3. Pressure to overcome scaling challenges for journalism will increase. The moderate scaling potential of news narrows paths to profitability. Making money on journalism alone requires substantial market segments with an above-average income and sufficient cultural capital to enjoy reading. A niche like business news may be the most profitable, given the high value of veracity and actionable knowledge to readers. Thus, ambitious legacy newspapers have become a niche product. Even The New York Times, with seven million subscribers (November 2020), is dwarfed by single YouTube stars with 100 million followers. The enduring profitability challenges are likely to inspire intensified efforts to improve the scalability of journalism.

4. A revised hybrid model which combines subscriptions with advertising may provide the most promising path toward long-term profitability. Der Spiegel, The Washington Post and others offer higher priced subscriptions with no or limited advertising, guaranteeing that behavioral data is harvested only to improve the product (Netflix-Fogg model). Lower priced versions are offered to customers accepting the surveillance of the attention economy (GoogleFacebook-Fogg model). Due to brand risk, such hybrid models must be approached carefully in terms of what kind of advertising and re-use of behavioral data they allow for. There is a business rationale for hybrid models, as the combination of a trusted brand, sufficient scale, and attractive demographics has a high advertising value (Cho, Huh \& Faber, 2014; Prendergast, Paliwal \& Mazodier, 2016). ${ }^{13}$ The same considerations come to play when newspapers pursue a strategy of cross-selling other products and services weakly related to their brand as journalistic entitites.

13 From a business strategy point of view, recent mass withdrawals of big companies' advertising spending on Facebook, due to Facebook's unwillingness to take down offensive and false material, highlight this issue. 


\section{Strategic management and business transformation in the news industry}

The ways in which market forces challenge journalism are staples of media and journalism studies. Research on the topic suggests that in spite of their noted idealism, media organizations tend to follow the same logic as other commercial enterprises (Albarran, Mierzejewska \& Jung, 2018; Kvalheim \& Barland, 2019; Picard, 2006; McManus, 1994, 2009). Thus, like in other industries, disruptive transformations in the media industry require management to offer a strategic sense of direction (Where are we going?) and skills in change management (How do we get there?).

Still, media management struggle with unique challenges because the news media is a key component of the architecture of liberal democracies, and frequently enjoy special legal protections and regulations. The media's unique societal role is reflected in leadership structures often embodying tensions between commercial interests and journalistic ideals. In a Norwegian context, this tension has been explored within the framework of Giddens' theory of structuration (Eide, 2000; Giddens, 1984; Roppen \& Allern, 2010; Bjerke, Fonn \& Mathisen, 2019). Eide identifies the editor-in-chief as having a vital influence on how journalistic ideals and market forces are reconciled, and what strategies should be adopted. Barland explores how this tension operates when adapting to a digital context (Barland, 2012).

We highlight two challenges confronting legacy newspapers seeking to fully adapt to the digital ecology. Firstly, journalism embodies a strong culture, ingrained in each media outlet, and solidified through the wider institutional structures in which the media industry is embedded. From a change perspective, strong professional cultures favor reproduction more than change. Secondly, newspapers embody an innovation culture focused on experiments and step-by-step changes, suited for organizations in stable and gradually evolving environments (Brunsson, 1985; Christensen et al., 2018; Thompson, 2003). Such a culture is maladapted to an environment undergoing disruptive change. We derive from these challenges a fifth and a sixth thesis: 
5. In adopting the "Netflix-Fogg" toolbox, management will have to challenge established journalistic norms, ideologies, and practices. A revision towards a humbler data-driven approach is a cultural transformation not likely to be achieved without resistance.

6. When a disruptive innovation is required, newspapers' traditional small-step innovation culture may hamper adaption. However, once a new AI-operational model is in place, this culture may be an asset accelerating change. ${ }^{14}$

\section{The Amedia Case \\ The Amedia Group}

Amedia, Norway's second largest media group, has 79 local newspapers and the national online newspaper Nettavisen. Their daily readership is 1.96 million (www.amedia.no). Since 2016, they are owned by the independent foundation, Amediastiftelsen.

The value proposition comprises both journalism and advertising. Amedia aim to be:

- the main communicator of local news

- an arena for public debate

- present and close to people's everyday lives in local communities

- be the main marketplace for buying, selling and marketing in their area.

Amedia is committed to journalistic and editorial ideals anchored since 1953 in the "Rights and duties of the editor." edom of expression, freedom of the press, and democracy, as well as the individual editors' freedom and integrity.

14 Prevalent agile methods of continuous improvement in software-driven enterprises have similarities with the innovation culture of news media (Sommer, 2019). 


\section{The innovation context of digital journalism in Amedia}

Norwegian newspapers have innovated since 1995 to adapt to digital challenges. We suggest a compressed storyline in phases, each with a specific management focus, putting the case study into context. ${ }^{16}$

The first phase commencing in 1995 was defined by the beginnings of news being published online. The second phase, initiated by the terrorist actions 09.11.2001, introduced in-depth reporting in real-time, which later became the normal practice. The third phase, initiated in 2003-2004, focused on interactivity and user involvement. The fourth phase, from 2010, is characterized by moving images and online newspapers including web TV (Barland, 2012, p. 135-142). The fifth is defined by users moving from PCs to mobile devices, strengthening opportunities for individualized content since they are "private" gadgets (Eide et al., 2012). This intensified competition from the platforms as they were positioned to undertake an exponentially intensified 24/7/365 data harvesting. The sixth phase starts in 2011 when the first newspapers began to publish behind paywalls for subscribers in Norway (Barland, 2015; Sjøvaag, 2016). The seventh phase is the nurturing of digital traffic and clickbait journalism aiming to protect advertising revenues. Norwegian media innovated on this trend, including Amedia's online service Buzzit. In the eighth phase, data harvesting dominates, contributing to redefining journalistic practices and advertising, focusing on all users becoming paying digital subscribers (Svendsen, Gulla \& Frøland, 2019).

Our study belongs to phase eight, which is ongoing. Despite innovation in earlier phases, we see phase eight as a major disruptive innovation compensating for deficiencies not solved by previous innovations.

16 See Barland J., Bakke N. A \& Fetveit A. (forthcoming in 2021) for a more extensive discussion
and reinterpretation of the innovation history of legacy news 2000-2020. 


\section{Key Findings}

\section{Business and operational model transformation and profitability}

The first radical measure of Amedia's transition involved implementing a version of the Netflix-Fogg operational model for journalism outlined in Theses 1-2. A key context was management acknowledging that the Buzzit initiative was failing. The objective was to protect advertising revenues, but according to (PN), the project proved "not profitable, and fostered a journalism detrimental to the journalistic and editorial ideals of Amedia." This prompted management to opt for a strategy in which subscriptions would become the main source of revenue. This required developing journalism that was deeply appreciated by the readers, and made the shift to the Netflix-Fogg model reasonable. Without this choice, "Amedia would be out of business today" (PN). The first version of this new strategy was launched in 2014. In 2015, following 13 years of decline, Amedia once again experienced growth in subscriptions.

Amedia got key early decisions right for building a state-of-the-art AI and machine learning operation:

- The subscriber's mobile phone number was selected as the primary key in their data model, around which personalized profiles could be built (The AiD project). ${ }^{17}$

- A paywall laid the foundation for the growth of digital subscriptions, enabling exclusive harvesting of behavioral data on its own platform outside the reach of competitors. "We had to move data away from Facebook, protecting it within our own walled garden through the AiD project" (PN).

- Amedia improved models for prediction and behavioral modification by enriching their databases with information from several public sources like Statistics Norway and the national vehicle register: "We have about 120 demographic variables that we can connect to individuals - represented as pseudonyms" (PN).

17 In Norway, subscribers' mobile numbers and addresses enable individual identification with an accuracy of $99.9 \%$. 
As (HS), Chief AI \& Machine Learning Officer, describes the harvesting operation: "We collect data from all legal sources, but the largest quantities and most important is behavioral data, which we collect when readers move around on our platform. Imagine an Excel sheet with 2000 columns and rows, that is about the amount of data we harvest per second. This data is linked to anonymized individuals, enabling personalization without knowing who they are."

Amedia use incentives as recommended by Fogg (2003) to get more people to login and to stay logged in and remain active, thereby enabling harvesting of more behavioral data. By combining data into higher order behavioral models, for instance, behavioral data and background variables like gender, age, and geography, Amedia is able to predict and modify behavior more efficiently. "We consistently go for harvesting data that improves predictive power" (PN). Clickbait data has low value because it does little to improve predictive power: "Our KPIs do not recognize traffic with a duration less than 10 seconds per article; if this happens frequently, it is an indication of journalistic failure" (HS). ${ }^{18}$

Amedia, as stated in the interviews, characterizes its journalistic strategy as data-informed and based on fairness and veracity. The interviewees draw a clear demarcation line against journalism involved in political activism. Presented with Swedish Aftonbladet, which acquired a vessel to save refugees during the 2015 crisis, they point out that this approach would be detrimental to building trust in journalism and the Amedia brand. The journalistic strategy as described in Figure 2 fits well with the journalistic ideals of foundation that owns Amedia and with Thesis 1.

\footnotetext{
18 KPI = Key Performance Indicator, a concept closely related with the Balanced Scorecard, which is an attempt to define a collection of metrics relevant for contious improvement of organizational performance (Kaplan \& Norton, 1996).
} 


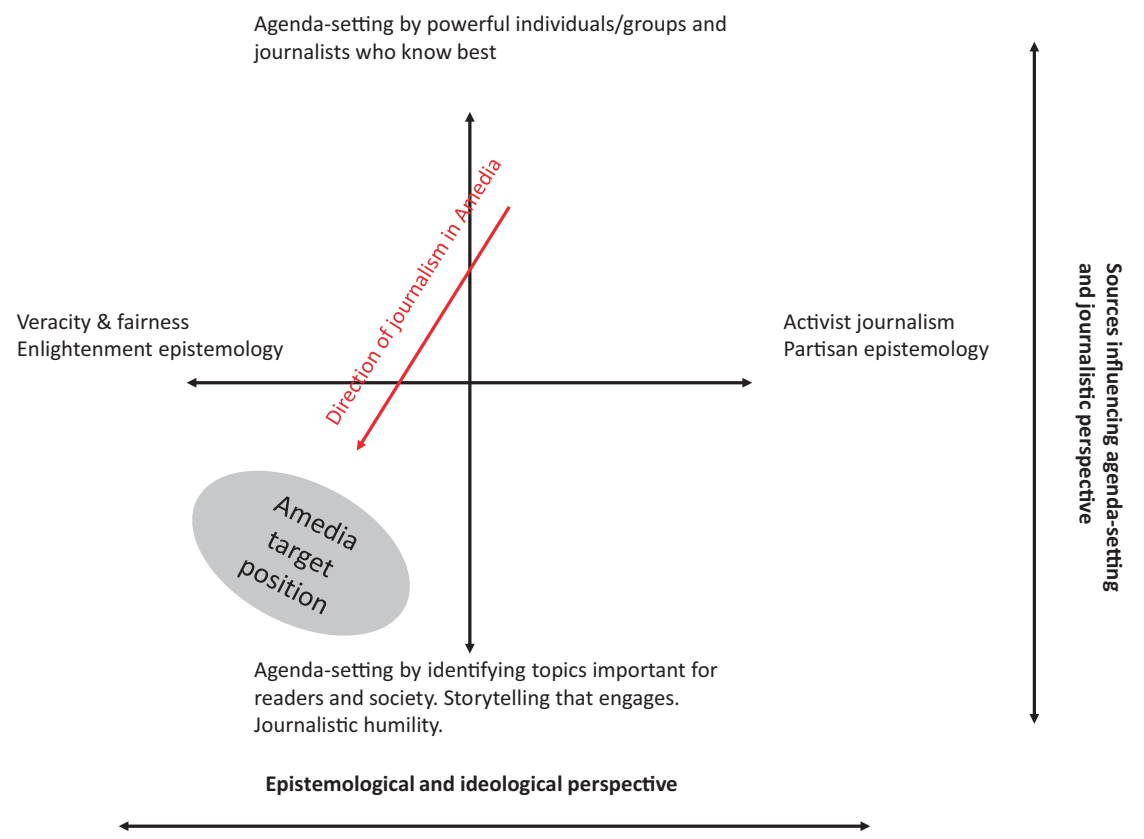

Figure 2 Journalistic strategy of Amedia - simplified

Later in their transition process, Amedia enhanced their advertising business by means of the tool box of the digital attention economy, enabling a hybrid model as outlined in Thesis 4. Since 2013, revenue changed from a ratio in favor of advertising to subscriptions of $61 \%-39 \%$, to $43 \%-57 \%$ in favor of subscriptions in 2019. Nevertheless, giving up on advertising is hardly a viable option. Based on 2019 figures, we estimate that Amedia would suffer a yearly net cash-flow loss of 600-800 million Norwegian kroner if advertising disappears. ${ }^{19}$

Automation is key to the advertising operation. For smaller advertising contracts, Amedia is not competitive with Google or Facebook, who offer user-friendly interfaces for self-service. Even for larger contracts, Amedia's operation with about 300 salespeople, seems rather laborintensive. Beyond this, Amedia aspires to refine the predictive power of its advertisement by capitalizing on the data, systems, and skills gained

19 We did not get product segment results from Amedia, so we made rough estimates based on information on cost-drivers and reasonable assumptions concerning distribution of overhead cost (Cooper \& Kaplan, 1993). 
from data-informed journalism. Presentations that Amedia have been making to advertisers seek to prove high conversion rates, and argue that for selected demographics and product categories, Amedia delivers better results than Facebook, Google and others (Amedia, 2020). Their competitive power is enabled by the operation inside the walled garden of AiD, which harvests behavioral data about large swaths of the Norwegian population unavailable to competitors.

Adding to the precision-targeting, Amedia's Director of Advertising (CT) emphasizes the safe context for advertisements provided by a strong brand based in trustworthy journalism. Amedia's sales pitch to advertisers points out that Amedia enjoys 20 times higher trust than Facebook. In compliance with Amedia's own as well as independent academic research, the pitch adds that highly trusted co-senders positively influence the credibility and effectiveness of advertisements (Cho, Huh \& Faber, 2014; Prendergast et al., 2016). Given the importance of trust to growth in subscriptions and for defence of their advertisement revenue, Amedia is careful not to act in ways that could undermine such trust. Thus, the Amedia management has decided not to pursue certain new business opportunities opened up by their AI operation because it could inflict reputational damages, even when it would be legal within the GDPR law: "We could sell prediction models to credit card companies, we know who will default the next few months. It would be easy money, but we don't do it. Our livelihood depends on trust. If trust declines, we undermine journalism, our mission" (HS).

Consistent with Thesis 4, Amedia optimizes their comptetitive power in the advertising market through combining predictive power delivered by unique data sets and algorithms with a strong brand. However, most of the advertising revenue still comes from paper. A major challenge ahead is to transfer revenue to the digital edition while the paper edition is phased out.

\section{Scaling}

Generally, AI and machine learning scale cognitive capacities of the journalistic operation to new levels across the 80 newspapers. Volume is key for AI and machine learning to work. PN notes that "We need 50,000 
examples, maybe 100,000, to train an AI algorithm." To scale across more outlets, Amedia has partnered with Aller Media, that now also uses AiD and acquire services from Amedia's AI and machine learning operation.

To further scale, software-based agents (robots) are used for editing front pages. Robots can also produce rudimentary journalism, like presentations of real estate for sale, and they can collect and edit data about the real estate market, weather forecasts, reports from sports events etc. Both HS \& PN emphasize that applying smart technologies that reduce the work load for journalists is a key strategy. As of 2020, some steps have been taken, but "robots are getting better and better" (PN), so those efforts are "likely to increase in the coming years" (HS). We see this as a big step toward building a more comprehensive AI-operational model where software agents increase their decision-making duties.

\section{Subscriptions, revenues, profitability}

Since 2015, key parameters of the subscription business have developed in the right direction. Advertising revenue contracted until 2017, after which it turned toward modest growth.

Table 1 Revenue 2013-19, million NOK

\begin{tabular}{|c|c|c|c|c|c|}
\hline & \multicolumn{2}{|c|}{ Revenue subscriptions } & \multicolumn{2}{c|}{ Revenue advertising $^{* \mid}$ Total revenue $^{\star}$} \\
\hline & NOK & $\%$ & NOK & $\%$ & NOK \\
\hline 2019 & 1679 & 57 & 1267 & 43 & 2946 \\
\hline 2018 & 1547 & 55 & 1261 & 45 & 2808 \\
\hline 2017 & 1490 & 55 & 1198 & 45 & 2688 \\
\hline 2016 & 1394 & 51 & 1367 & 49 & 2761 \\
\hline 2015 & 1367 & 42 & 1835 & 58 & 3202 \\
\hline 2014 & 1446 & 42 & 2025 & 58 & 3571 \\
\hline 2013 & 1458 & 39 & 2263 & 61 & 3821 \\
\hline
\end{tabular}

*Total revenue only includes subscription and advertising. Other revenue not included. Amedia yearly reports 2013-2019.

Between 2017-2019 EBITDA increased from 476 to 520 million. If advertising was left out, Amedia would have a yearly negative EBITDA in the range 100-400 million NOK during those three years. By the end of 2019, $71 \%$ of the subscribers are digital, but $29 \%$ still had a paper-only 
subscription. The transformation to a fully digital operation is far from completed.

\section{Journalistic ideals, brand, and trust}

By applying the Netflix-Fogg model, Amedia management set in motion a process of continuous improvement of the journalistic product. "It is true that Amedia in 2013-14 started to apply key elements of the Google/ Facebook toolbox, but with the fundamental difference that we did not let advertising guide data collection and algorithms. From the outset, we optimized towards the quality and relevance of our content production" (HS). The continuous learning enabled by this model produces changes in the journalistic practices, like the following:

- The balance between topics has undergone major changes to better reflect reader preferences. For instance, readers proved to be less interested in sport and culture and significantly more interested in local business news than editors had assumed.

- Real-time data on reader engagement offers journalists continuous feedback on their articles, enabling optimization on the fly. Most articles are published in two versions for A and B testing, enabling aspects like the headline, the led paragraph, photos, or the journalistic angle, to be optimized during the day (JØL, HS).

- Algorithms improve constantly. They predict churn of individual customers sufficiently in advance to implement measures to avoid it, and, with a certainty of $90 \%$, they can predict whether an article will elicit three more new subscriptions. They can predict the number of likely readers and accumulated reading minutes for an article (HS, PN).

- Engaged readers are likely to keep subscribing. PN explains: "We have 20-30 variables, similar to the Financial Times' approach: RFV (Recency $=$ last read, Frequency $=$ frequency of visits, Volume $=$ how many articles/reading time). Time consumed is very important. We measure how many seconds you have been active on our pages, on every item, open content, and behind subscription walls. We feed all into machine-learning algorithms trained on our AiD-base, and 
predict behavior in terms of churn of subscriptions and the likeliness of signing up new subscribers."

The departments of journalistic product development and ID data are working together. They continuously improve on journalistic strategies and AI operations to the benefit of journalists' ability to write stories that generate engagement and thereby more subscriptions. By optimizing relevance to key constituents of the readership, engagement can be nurtured across demographies.

KPIs are a key management tool. A thoughtful process is required to define and guide their use. "There are a lot of things we can do, but decide not to take advantage of. We could have made, but chosen not to do, a system providing the journalist with red, yellow, green lights, where the article is not allowed to be published before the system predicts $\mathrm{x}$ number of readers or $x$ number of new subscriptions." (PN)

The data-informed approach has inspired a more diverse selection of sources and themes. Previously, much content was prioritized through leverage exercised by powerful individuals, companies, political parties, organizations, and interest groups. Under the data-informed regime, their influence is weakened. Actionable knowledge with high relevance to readers' lives - stories that offer insights of value - become more important. Apparently, for Amedia, the AI-driven operation provides excellent supports for fair and fact-driven journalism. The local context also puts a premium on veracity, since inaccuracies and biases are easily revealed and may hurt brand reputation. ${ }^{20}$

Amedia's transition appears beneficial to the fulfillment of its stated journalistic ideals, and improves profitability which in itself have a secondary positive effect on journalism. PN notes: "In 2012-2015, we were in an existential fight to survive, and probably lost the journalistic and publisher ideals of serving democracy out of sight ... in 2019, the big difference is that increased profitability makes it easier to align with our ideals." ${ }^{21}$

20 Our assessment is based on our informants and a cursory look at some of the outlets through access to all of the Amedia publications. 


\section{Leadership, culture, and transformation}

The Amedia case is a story of a comprehensive, management-driven process of change, which, over the course of several years, has elevated journalism to become the most significant source of revenue. Given 80 newspapers, with different cultures and readerships, it is no surprise that there are differences between front-runners of change and laggards. The AI operation creates new opportunities, but if the technologies and the KPIs are not utilized by editors able to bring about a cultural shift through which journalists come to embrace the new journalistic tool box, only modest improvements can be expected.

By employing the right editor, not changing anything else, there are examples of newspapers nearly doubling subscriptions and decisively improving profitability within a year. "The one variable that overshadows all others is the editor. When the editor makes the right decisions, raises the right discussions, leads the editorial morning summit well, follows up the individual journalists, we always see rapid improvements" (PN). The cultural transformation is further accelerated by a strategy of recruiting a more diverse pool of journalists, better reflecting readers in terms of age, gender, and biography (GJ, JØL). Data-informed journalism as practiced by Amedia requires more humility, less moralizing, less activism, less arrogance. This attitude also implies a willingness to apply new sources of information for agenda-setting and ensuring relevance becomes vital. Journalism has become more complex, requiring intensified teamwork across departments, involving new skillsets and knowledge bases and increases in the significance of both human2AI and $\mathrm{AI} 2 \mathrm{AI}$ interaction.

Given competent leadership, most journalists have embraced the changes. Our informants describe a process where 13 years of decline - of being aboard a sinking ship - is replaced by the gratitude of being on a winning team. PN elaborates: "We made dashboards for every journalist, enabling them to follow their own articles in terms of number of readers and duration of reading. The journalists become aware of their own performance. When their article generated 20 new subscriptions yesterday, they see that 'I am making a difference.' In a crisis, this means a lot. Hey, we have started to grow subscriptions again." Culturally, the continuous improvement processes of the Netflix-Fogg model have been fairly easy 
to integrate, as long as journalists accept prioritizations to be based more on what the data tells, rather than on the mere gut feeling of editors or on ideological bias. Agile methods of software development and journalistic product development are merging successfully within the new model.

The focus on journalism as the main value proposition and source of revenue has changed the roles and skillsets of leadership within the industry. When advertising was the main source of revenue, decisions were biased towards optimizing the newspaper as an efficient vehicle for advertising. When journalism becomes the dominant value driver, decisions about digital user interfaces, placement of ads etc., become subjugated to the journalistic objective of keeping readers engaged and satisfied. Piechota and Brock (2019) indicate that this is a general trend in the industry, labeling it the "audience first" approach. As journalism becomes the key part of the commercial value propostion, the future profile for top managers in news media evolves into a more integrated role combining the previously separated CEO and editor roles (Barland, 2019).

\section{Conclusions}

The research question raised at the beginning of this chapter enquired into the ways in which legacy newspapers might digitally transform their business models and operational models while retaining profitability and protecting journalistic ideals. To answer this, we developed six theses related to the required changes in business models, operational models, and the challenges of the transformation itself. As this chapter has demonstrated, this is a complex, long-term endeavor, impacting the entire organization. Nevertheless, we think the Amedia case largely gives support to the six thesis, which generated four findings of particular importance.

First, we believe the implementation of an AI operational model building a new business increasingly on software instead of humans - is economically and journalistically beneficial and increases the chances of legacy media to survive in the marketplace. As AI and machine learning require scale, risk is increased for smaller outlets.

Second, within this new AI-driven framework, different journalistic value propositions may be profitabile. We believe that veracity-oriented 
strategies focusing on actionable knowledge for readers have more consistently positive prospects in a market abundant with information and disinformation than partisan outlets. Amedia and some leading legacy newspapers marching in the general direction that Amedia has chosen indicate substantial alignment between commercial forces and ambitious journalistic ideals and value propositions.

Third, for most outlets, it is difficult to see viable alternatives ensuring high profitability besides the combination of subscription and advertising revenue that Amedia is pursuing. ${ }^{22}$ In the Norwegian context, there is a business case for Amedia to consolidate their data operation with the Schibsted Group, to build a more robust strategic alternative to take on Google and Facebook in the advertising market. This was hinted at by some informants, with the caveat that cultural differences and competing ambitious would make a consolidation difficult.

Fourth, key aspects of leadership are in transition. The emergence of subscriptions as the main source of revenue makes an integrated CEO/ Chief Editor role the most likely model looking ahead. Furthermore, to achieve commercial success, it becomes a more acute management responsibility to protect trust, build the brand, and reduce the "hypocrisy" of combining quality journalism with advertising. This bodes well for ambitious journalistic ideals, as advertising concerns become less influential within news organizations. The implementation of an AIoperational model is transforming organizational structures and processes, as well as journalism itself. As an increasing share of communication and decisions are made between humans and AI agents and through pure AI2AI processes, a new type of digitized, software-based news organization is emerging. This trend is not likely to cease since organizations built on AI scale better in virtually all dimensions (Iansiti \& Lakhani, 2019). Looking ahead, news media organizations that do not effectively utilize intelligent AI agents are likely to struggle both to deliver editorial quality and retain profits. Thus, the future core skills of news organizations

22 Compensating loss of advertising revenue by cross-selling of products- and services with a weak relation to journalism has so far produced moderate success in the industry. The distribution power of legacy media is limited compared with other digital channels, and the need for protecting the journalistic brand makes expansive efforts in this direction risky. 
are likely to combine tech-savvy and journalistic competency in new and innovative ways.

An important topic not key to the scope of this chapter is the direction of influence in the mutual AI-mediated relationship between journalism and readership. That is, to what extent may a more humble and data-informed journalism become a capitulation to an unenlightened readership? There is room for different responses and outcomes related to this question, as reader preferences are not given but also influenced and shaped journalistic strategies. However, it seems clear that commercially successful journalistic responses must be much more attentive to reader preferences than most legacy media organizations have been in the pre-digital world, when they controlled the public sphere and often thrived commercially under semi-monopoly conditions. Aftenposten seeks to balance this through an editorial strategy where about $50 \%$ of the recommendations to individual readers are based on previous reading patterns, whereas $50 \%$ are based on an editorial view of what informed readers should be exposed to (Hansen, 2020).

From what we can observe, the changes the news industry currently is undergoing share commonalities with previous "industrial revolutions," like the spread of mass production in the early $2 \mathrm{O}^{\text {th }}$ century as embodied in Taylor's "Principles of Scientific Management" (Taylor, 1911), and the similar spread of the Toyota Production System (TPS) and Just-in-Time (JIT) principles in the 1980 os and 1990s. As in previous shifts, news organizations that ignore or maladapt to the current disruption may struggle to survive (Womack, Jones \& Roos, 2007).

The big platforms are likely to remain deeply entangled with news media. Newspapers with significant revenues dependent on Facebook and Google are exposed to considerable risk. Minor changes in platform policy and algorithms may have detrimental effects on their revenues. Amedia is aware of the dangers: "Facebook cannot be wished away - it is about optimization, utilizing advantages and protecting against downsides" (PN). Further, Facebook plays a key role in the Amedia ecology for recruiting new subscribers: "Measured against total traffic, Facebook is very important in routing of external traffic into our walled garden." (PN) (cf. Myllylahti, 2020). When platforms go in new directions, this 
may affect the strategic options available to the news industry (van Djick, Poell \& de Waal, 2018). Looking ahead, we believe a wider ecological perspective vindicates more research.

\section{Acknowledgements}

Thanks to key individuals in current and former leadership at Amedia and Schibsted Group, who generously shared experiences and data with us. Grzegorz Piechota at INMA generously took time to discuss "audience first" issues. Thanks also to copy and content editor Kiersten Leigh Johnson for helping to improve the precision and flow of our prose.

\section{References}

Albarran, A. B., Mierzejewska, B. \& Jung, J. (2018). Handbook of media management and economics (2 utg.). Routledge. https://doi.org/10.4324/9781315189918

Amedia. (2020). Sales presentation of Amedia advertising products [Internal document]. Amedia.

Barland, J. (2012). Journalistikk for markedet. Redaksjonell produktutvikling i VG og Aftonbladet på papir og net 1995-2010 [Doctoral dissertation, University of Oslo]. DUO Vitenarkiv. http://urn.nb.no/URN:NBN:no-32655

Barland, J. (2015). Research brief: Innovation for new revenue streams from digital readers: The case of VG+. The Journal of Media Innovations, 2(1), 123-30. https://doi.org/10.5617/jmi.v2i1.952

Barland, J. (2019). Redaktøren - toppleder eller reportasjeleder? (Report). Norsk Redaktørforening. http://hdl.handle.net/11250/2597163

Barland, J., Bakke N. A \& Fetveit A. (2021). Disruptive innovations and paradigmatic shifts in journalism as a business. (Forthcoming article.)

Baum, J. A. C. \& Rao, H. (2004). Evolutionary dynamics of organizational populations and communities. In M. S. Poole \& A. H. Van de Ven (Eds.), Handbook of organizational change and innovation. Oxford University Press.

Benton, J. (2014, May 15). The leaked New York Times innovation report is one of the key documents of this media age. NiemanLab. Retrieved October 15 , 2020 from https://www.niemanlab.org/2014/05/the-leaked-new-york-timesinnovation-report-is-one-of-the-key-documents-of-this-media-age/

Bjerke, P., Fonn, \& Mathisen (Eds.). (2019). Journalistikk, profesjon og endring. Orkana Akademisk. 
Brunsson, N. (1985). The irrational organization: Irrationality as a basis for organizational action and change. J. Wiley \& Sons.

Brunsson, N. (1989). The organisation of hypocrisy: Talk, decisions and actions in organizations. Wiley.

Brynjolfsson, E., Mitchell, T. \& Rock, D. (2018). What can machines learn, and what does it mean for occupations and the economy? AEA Papers and Proceedings, 108, 43-47. https://doi.org/10.1257/pandp.20181019

Bueno, C. C. (2017). Labor, time and power in cognitive capitalism. Rowman \& Littlefield International Ltd.

Buffett, W. (2014). The essays of Warren Buffett. Lessons for investors and managers (L. A. Cunningham, Ed.) Wiley.

Bursztyn, L., Rao, A., Roth, D. \& Yanagizawa-Drott, D. (2020). Misinformation during a pandemic (Working Paper NO. 2020-44). Becker Friedman Institute for economics, University of Chicago. Retrieved October 15, 2020 from https://bfi. uchicago.edu/wp-content/uploads/BFI_WP_202044.pdf

Cho, S., Huh, J. \& Faber, R. J. (2014). The influence of sender trust and advertiser trust on multistage effects of viral advertising. Journal of Advertising, 43(1), 100-114. https://doi.org/10.108o/oo913367.2013.811707

Choudary, S. P. (2015). Platform scale: How an emerging business model helps startups build large empires with minimum investment. Platform Thinking Lab.

Christensen, C. M., Raynor, M. E. \& McDonald, R. (2015, December). What is disruptive innovation? Harvard Business Review. https://hbr.org/2015/12/what-isdisruptive-innovation

Christensen, C. M., McDonald, R., Altman, E. J. \& Palmer, E. (2018). Disruptive innovation: An intellectual history and directions for future research. Journal of Management Studies, 55(7), 1043-1078. https://doi.org/10.1111/joms.12349

Cooper, R. \& Kaplan, R. (1993). Implementing activity-based cost management: Moving from analysis to action: Implementation experiences at eight companies. Institute of Management Accountants.

Cyert, R. M. \& March, J. G. (1992). A behavioral theory of the firm (2nd ed.). Blackwell.

D'Souza, D. (2020, April 22). Netflix doesn't want to talk about binge-watching. Investopedia. https://www.investopedia.com/tech/netflix-obsessed-bingewatching-and-its-problem/

Edelman, K. J. (2020, June 4). NY Times 'civil war': Opinion writer Bari Weiss gets buried by colleagues for tweeting her takes on newsroom friction after Cotton op-ed. Mediaite. Retrieved from https://www.mediaite.com/print/ny-timescivilwar-opinion-writer-bari-weiss-gets-buried-by-colleagues-for-tweeting-her-takeson-newsroom-friction-after-cotton-op-ed/

Eide, M. (200o). Den redigerende makt. Redaktørrollens norske historie. Høyskoleforlaget. 
Eide, M., Larsen, L. O. \& Sjøvaag, H. (Eds.). (2012). Nytt på nett og brett. Journalistikk i forandring. Universitetsforlaget.

Fogg, B. J. (2003) Persuasive technology: Using computers to change what we think and do. Morgan Kaufmann Publishers.

Forrester, J. (1988). Planning in the face of power. University of California Press.

Gathman, F. (2020, June 11). Wir müssen so neutral sein wie möglich. Der Spiegel. https://www.spiegel.de/kultur/wir-muessen-so-neutral-sein-wie-moeglich-a1820e9d1-9cf6-4d3f-8965-aa7a59f8ec66

Giddens, A. (1984). The constitution of society: Outline of the theory of structuration. Polity Press.

Goldhaber, M. H. (1997). The attention economy and the net. First Monday, 2(4). Retrieved October 16, 2020 from http://firstmonday.org/ojs/index.php/fm/article/ view/519/440

Groth, L. (1999). Future organizational design: The scope for the IT-based enterprise. John Wiley.

Hansen, E. E. (2020, August). Audience first strategy in Aftenposten (INMA Talk). International News Media Association.

Horwitz, J. \& Seetharaman, D. (2020, March 26). Facebook executives shut down efforts to make the site less divisive. The Wall Street Journal. https://www.wsj. com/articles/facebook-knows-it-encourages-division-top-executives-nixedsolutions-11590507499

Iansiti, M. \& Lakhani, R. L. (2019). Competing in the age of AI: Strategy and leadership when algorithms and networks run the world. Harvard Business Review Press.

Kahneman, D. (2012). Thinking, fast and slow. Farrar, Straus and Giroux.

Kaplan, R. S \& Norton, D. P. (1996). The balanced scorecard: Translating strategy into action. Harvard Business School Press.

Kvalheim, N. \& Barland, J. (2019, September 30). Commercialization of journalism. Oxford Research Encyclopedia of Communication. https://doi.org/10.1093/ acrefore/9780190228613.013.788

Lewin, A. Y., Weigelt, C. B. \& Emery, J. D. (2004). Adaptation and selection in strategy and change: Perspectives on strategic change in organizations. I M. S. Poole, \& A. H. Van de Ven (Eds.), Handbook of organizational change and innovation (pp. 108-159). Oxford University Press.

March, J. G. \& Simon, H. A. (1993) Organizations (2nd ed.). Wiley-Blackwell. McAfee, A. \& Brynjolfsson, E. (2017). Machine. Platform. Crowd. Norton \& Company.

McManus, J. H. (1994). Market-driven journalism: Let the citizen beware? Sage.

McManus, J. H. (2009). The commercialization of news. In K. Wahl-Jorgensen \& T. Hanitzsch (Eds.), The handbook of journalism studies. Routledge. 
McNamee, R. (2019). Zucked: Waking up to the Facebook catastrophe. Penguin Press. Myllylahti, M. (2020). By boycotting big tech platforms, media companies gain control but lose conversions. INMA: Media Research Blog. https://www.inma. org/blogs/research/post.cfm/by-boycotting-quitting-big-tech-platforms-mediacompanies-gain-control-but-lose-conversions

The New York Times. (2014, March 24). Innovation. Retrieved October 16, 2020 from https://www.slideshare.net/VeronicaRRSouza/224608514-the-full-newyork-times-innovation-report-2014

The New York Times. (2017). Journalism that stands apart: The report of the 2020 group. https://www.nytimes.com/projects/2020-report/index.html

Oehmke, P. (2020, June 11). Die Zeit der Neutralität ist vorbei. Der Spiegel. https:// www.spiegel.de/kultur/new-york-times-die-zeit-der-neutralitaet-ist-vorbei-a5ccaa4e4-eca2-4a2e-b2d7-22e6a484f8ce

Osterwalder, A. \& Pigneur, Y. (2010). Business model generation: A handbook for visionaries, game changers, and challengers. Wiley.

Pettersen, L. \& Krumsvik, A. H. (2019). Rocking the boat: Proposing a participatory business model for news. Journal of Media Innovations. http://dx.doi.org/10.5617/ jomi.6561

Picard, R. G. (2006). Journalism, value creation and the future of news organizations [Paper]. Harvard University.

Piechota G. \& Brock G. (2019). The evolving role of newsrooms in the reader revenue model (Report). International News Media Association. https://www.inma.org/ report-detail.cfm?pubid $=206$

Prendergast, G., Paliwal, A. \& Mazodier, M. (2016). The hidden factors behind sponsorship and image transfer: Considerations for bilateral image transfer among sponsors and events. Journal of Advertising Research, 56(2), 132-135. https://doi.org/10.2501/JAR-2016-026

Ray, J. (2011, April 8). Facebook: A case study of strategic leadership. SSRN. http:// dx.doi.org/10.2139/ssrn.2103975

Roppen, J. \& Allern, S. (Eds.). (2010). Journalistikkens samfunnsoppdrag. IJ-forlaget. Rubin, P. (2020, January 21). With interactive TV, every viewer is a showrunner now. Wired. https://www.wired.com/story/netflix-interactive-tv-every-viewer-is-ashowrunner/

Sjøvaag, H. (2016). Introducing the paywall. Journalism Practice, 10(3), 304-322. https://doi.org/10.108o/17512786.2015.1017595

Silverman, C. (Ed.). (2019). Verification handbook for journalists. http:// verificationhandbook.com

Simon, H. A. (1971). Designing organizations for an information-rich world. In M. Greenberger (Ed.), Computers communication and the public interest (pp. 40-41). The Johns Hopkins Press. 
Sommer, B. (2019). Scrum - an introduction: A guide to the rules of the game, its history and relation to agile. Retrieved October 16, 2020 from https://leanpub. com/scrum-introduction

Stephens, B. (2020, October 9). The 1619 chronicles [Opinion]. The New Tork Times. https://www.nytimes.com/2020/10/o9/opinion/nyt-1619-projectcriticisms.html

Storsul, T. \& Krumsvik, A. H. (Eds.). (2013). Media innovations: A multidisciplinary study of change. Nordicom.

Svendsen R. D., Gulla J. D. \& Frøland J. (2019). Anbefaling av nyhetsinnhold i praksis: Fra algoritmer til personaliserte nyheter. Norsk medietidsskrift, 26(1), 1-22. https://doi.org/10.18261/ISSN.0805-9535-2019-01-04

Sullivan, A. (2020, Junbe 12). Is there still room for debate? New York Magazine: Intelligencer. https://nymag.com/intelligencer/2020/o6/andrew-sullivan-is-therestill-room-for-debate.html

Taylor, F. W. (1911). Principles of scientific management. Harper \& Brothers Publishers.

Thompson, J. D. (2003). Organizations in action: Social science bases of administrative theory. McGraw-Hill. (Published 1967.)

van Dijck, J., Poell, T. \& de Waal, M. (2018). The platform society: Public values in a connective world. Oxford University Press.

Villi, M. \& Picard, R. G. (2018). Transformation and innovation of media business models. In Deuze \& Prenger (Eds.), Making media: Production, practices, and professions (pp. 121-132). Amsterdam University Press.

Vosoughi, S., Roy, D. \& Aral, S. (2018). The spread of true and false news online. Science, 359(6380), 1146-1151. https://doi.org/10.1126/science.aap9559

Welch, M. (2020, June 6). Journalists abandoning 'objectivity' for 'moral clarity' really just want to call people immoral. Reason: Free minds and free markets. https://reason.com/2020/o6/24/journalists-abandoning-objectivity-for-moralclarity-really-just-want-to-call-people-immoral/

Williamson, O. E. \& Winter, S. G. (Eds.). (1993). The nature of the firm: Origins, evolution, and development. Oxford University Press.

Womack, J. P., Jones, D. \& Roos, D. (2007). The machine that changed the world: The story of lean production: Toyota's secret weapon in the global car wars that is now revolutionizing world industry. Free Press.

$\mathrm{Wu}, \mathrm{T}$. (2016). The attention merchants: The epic scramble to get inside our heads. Knoph.

Zuboff, S. (2019). The age of surveillance capitalism: The fight for a human future at the new frontier of power. Public Affairs.

Zuckerberg, M. (2020, September 5). Protecting democracy is an arms race. Here's how Facebook can help [Opinion]. The Washington Post. https://www. washingtonpost.com/opinions/mark-zuckerberg-protecting-democracy-is-an- 
arms-race-heres-how-facebook-can-help-win-it/2018/o9/o4/53b3c8ee-bo83-11e89a6a-565d92a3585d_story.html

Yin, R. K. (2017). Case study research (6th ed.). Sage.

\section{Other material}

Amedia's mission, business idea and publisher statement: https://www.amedia.no/ om-amedia/vare_verdier/ (Retrieved October 12, 2020)

Amedia annual reports:

2019 https:/www.amedia.no/globalassets/dokumenter/amedia-arsrapport-2019.pdf 2018 https:/www.amedia.no/globalassets/dokumenter/amedia-arsrapport-2018.pdf 2017 https://www.amedia.no/globalassets/dokumenter/amedia-arsrapport-2017.pdf 2016 https://www.amedia.no/globalassets/dokumenter/amedia-arsrapport-2016.pdf 2015 https://www.amedia.no/globalassets/dokumenter/amedia-arsrapport-2015.pdf 2014 http://www.amedia.no/globalassets/dokumenter/amedia-arsrapport-2014.pdf 2013 http://www.medienorge.uib.no/files/Eksterne_pub/

Amedia_\%C3\%A5rsrapport_2013.pdf

"Rights and duties of the editor" https://www.nored.no/Redaktoeransvar/

Redaktoerplakaten/Redaktoerplakaten-engelsk

"Code of Ethics of the Norwegian Press" https://presse.no/pfu/etiske-regler/vaervarsom-plakaten/vvpl-engelsk/ 


\title{
Helseledelse på arbeidsplassen- sunn prestasjonskultur og individuelle HR-drivere bak organisatoriske prestasjoner
}

\author{
Rune Bjerke \\ Høyskolen Kristiania
}

\begin{abstract}
The Norwegian Institute of Public Health («Folkehelseinstituttet») (FHI) states that Norway faces several major health challenges. Sick leave is 6\%, costing companies and the state tens of billions annually. The FHI proposes, with the support of the Public Health Act («Folkehelseloven») and the national strategy «HelseOmsorg21», that preventive measures should be developed against the negative lifestyle factors to decrease the number of new cases in the life-reducing disease group. The purpose of this chapter is to answer why and how organizations should develop a healthy performance culture through strategic health care management supported by additional health, environmental and safety («HMS») directives. Based on cross-disciplinary theorizing, a definition of a healthy performance culture is proposed. This type of culture consists of dimensions such as health objectives, shared health values, supportive health environment, openness, goal-oriented and value-based behavior of leaders and employees, and a winning mindset. The chapter also underscores the importance of the related individual HR drivers like fun at work, engagement, physical and mental health. The company cases Schibsted/VG, Gjensidige, Findus and Wilhelmsen and findings from in-depth interviews show that health-promoting activities may be the result of a HR strategy, or just individuals' initiative and voluntariness among the companies' sports enthusiasts. The case of Findus exemplifies an ongoing development toward a healthy performance culture and the importance of leaders' participation. The findings support the theoretical model showing the relations between a healthy performance culture,
\end{abstract}

Sitering av denne artikkelen: Bjerke, R. (2020). Helseledelse på arbeidsplassen - sunn prestasjonskultur og individuelle HR-drivere bak organisatoriske prestasjoner. I J. Bastesen, B. K. Lange, H. E. Næss \& A. N. Thon (Red.), Ledelse av mennesker $i$ det nye arbeidslivet (Kap. 2, s. 53-86). Oslo: Cappelen Damm Akademisk. https://doi.org/10.23865/noasp.118.ch2

Lisens: CC-BY 4.o. 
individual HR drivers and organizational performance. A framework for developing a healthy performance culture is presented.

Keywords: Healthy performance culture, employee mental and physical health, workplace health management, HR-strategy, physical activity programs

\section{Innledning}

Det totale sykefraværet blant den sysselsatte befolkningen i Norge er på ca. $6 \%$, og har vært forholdsvis stabilt de siste årene (Høydahl, 2020). Mange helseproblemer ender i sykefravær og tapte årsverk (Andersen \& Nossen, 2018; Folkehelseinstituttet, 2018b). Kostnadene ved sykefravær er betydelige. En HR-medarbeider hos Nordic Choice Hotels uttalte at med personalkostnader på 2,9 milliarder i 2015 vil hver \% i redusert sykefravær utgjøre kostnadsbesparelser på kr. 20-25 millioner (Bjerke, 2016). Bjerke og Elvekrok (2020) viser at Aker ASA, i rollen som sponsor for det norske skilandslaget, reduserte sykefraværet med o,5 \%. Gjennom sponsorsamarbeidet og det helsefremmende programmet rettet mot ansatte tilsvarte denne reduksjonen en besparelse på kr. 50 millioner. Derfor er det interessant å stille spørsmål om det er et potensial for verdiskapning blant norske organisasjoner ved å utvikle en helsekultur (Golaszewski, Hoebbel, Crossley, Foley \& Dorn, 2008). Det er nemlig dokumentert at fysisk trening kan redusere sykefravær og støtte utviklingen av en organisatorisk helsekultur (Golaszewski et al., 2008). Dessuten er dårlig helse forbundet med en betydelig reduksjon i arbeidsytelse, noe som indikerer at helsefremmende tiltak kan ha en positiv innvirkning på prestasjonen (Ford, Cerasoli, Higgins \& Decasare, 2011). Samtidig har flere studier har tatt opp ulike kilder til arbeidsstress, forårsaket av for eksempel lange arbeidsdager, overtid, tidspress og uklare roller/rolletvetydighet (Crawford, LePine \& Rich, 2010; Kamarck et al, 2005). Stress påvirker også ansattes fysiske og psykiske helse negativt, noe som fører til at organisasjoner og samfunnet blir belastet økonomisk (Bono, Glomb, Shen, Kim \& Koch, 2013). Slik kan vi si at arbeidstageres mentale og fysiske helsetilstand utgjør en del av den norske folkehelsen.

Folkehelseloven, som trådte i kraft 1. januar, 2012, er basert på fem viktige prinsipper: medvirkning; bærekraft; helse i alt vi gjør; føre var; sosial 
utjevning (Helse- og omsorgsdepartementet, 2019). Samtidig er visjonen til den nasjonale strategien HelseOmsorg 21 (av 2014): kunnskap, innovasjon og næringsutvikling for bedre folkehelse (Helse- og omsorgsdepartementet, 2014). Folkehelseloven fastslår også at alle sektorer har et ansvar for folkehelsen (helsesektoren og alle forvaltningsnivåer). Det er nemlig flere utfordringer med den norske folkehelsen. Folkehelseinstituttet (FHI) rapporterte at hovedårsakene til sykdom og redusert helse i Norge er muskel- og skjelettsykdommer, psykiske plager og lidelser, hjerte- og karsykdommer og kreft. Årlig behandles omkring 70 ooo for hjerte- og karsykdom, og det oppdages mer enn 30 ooo krefttilfeller hvert år. Nesten $6 \%$ av de under 75 år bruker antidepressiva, og årlig vil en av fem voksne oppleve en psykisk lidelse. Antall personer som må leve med diabetes stiger, og omkring 10 \% av de voksne røyker daglig. FHI slår fast at mange inntar for mye sukker og er fysisk inaktive (Folkehelseinstituttet, 2018a).

Denne sykdomsbyrden koster mye. De totale helseutgiftene for befolkningen er i 2019 beregnet til å bli 372 milliarder kroner. Behandlingskostnadene står for så mye som over 25 \% av statsbudsjettet på 1377 milliarder, mens kun $2,5 \%$ ble brukt til forebyggende helsearbeid (Statistisk sentralbyrå, 2020a). Bare fedme er beregnet til å koste Norge 68 milliarder kroner årlig. Professor i medisin ved Universitetet i Oslo, Jøran Hjelmesæth, uttaler at det er en klar sammenheng mellom fedme og hjerte- og karsykdom, hjerneslag, enkelte kreftsykdommer, diabetes og psykiske lidelser (Bordvik \& Hafstad, 2019). FHI foreslår at det bør rettes forebyggende tiltak mot livsforkortende livstilfaktorer (FHI, 2018b). Fysisk aktivitet har vist seg å beskytte mot flere sykdommer og tilstander som hjerte- og karsykdommer, høyt blodtrykk, diabetes 2 og overvekt (Pronk \& Kottke, 2009), og det er anbefalt minst tre treningsøkter i uken av forholdsmessig høy intensitet for å oppnå positiv effekt på sykefraværet (Proper, van den Heuvel, De Vroome, Hildebrandt \& Van der Beek, 2006). Gitt at sosial interaksjon, nære relasjoner, nok fysisk aktivitet, normalt blodtrykk og ren luft er livsforlengende faktorer (Holt-Lunstad, Smith, Baker, Harris \& Stephenson, 2015), kan en del av løsningen ligge her. Som vist over, organisasjoner kan jobbe med forebyggende helsearbeid og de livsforlengende faktorene for å forbedre den mentale og fysiske helsen hos den sysselsatte delen av befolkningen på 2,7 millioner personer (for året 2019) (Statistisk sentralbyrå, 2020b). 
Derfor handler dette kapitlet om hvordan bedrifter og organisasjoner kan ivareta ansattes mentale og fysiske helse gjennom nedfelte HRstrategier og utviklingen av en helsekultur eller en sunn prestasjonskultur. I henhold til de Waal (2007) kjennetegnes en prestasjonskultur med blant annet et vinnende tankesett, utmerkede resultater i alt hva organisasjonen gjør, delte kjerneverdier og identitet, en følelse av fellesskap, åpenhet, frihet og autonomi. En helsekultur defineres som en sosial og organisatorisk konstruksjon med et sett av felles kjerneverdier, antagelser og forventninger som styrer hvordan ansatte tenker, føler og oppfører seg for å forbedre personlig og ansattes helse (Golaszewski et al., 2008). Ved å se nærmere på casene Findus, Schibsted/VG, Gjensidige, og Wilhemsen, undersøker jeg hvordan noen norske bedrifter organiserer tilretteleggingen av helsefremmende aktiviteter ved hjelp av tre forskningsspørsmål. De omhandler helsekultur/sunn prestasjonskultur, motiver (hvorfor og hvordan) bak tilretteleggingen av fysiske aktiviteter og hvordan fasiliteter og strukturelle faktorer kan spille inn:

1. Er det indikasjoner på at norske bedrifter utvikler en helsekultur eller en sunn prestasjonskultur?

2. Hvordan og hvorfor tilrettelegger bedriftene fysisk aktivitet på arbeidsplassen?

3. Hva slags fasiliteter og strukturelle faktorer tilbys ansatte?

Formålet med å undersøke hvordan og hvorfor noen norske arbeidsgivere legger til rette for fysisk aktivitet på arbeidsplassen, inngår i en større sammenheng: Et slikt helseløft kan også føre til en bedring i folkehelsen generelt, noe som igjen kan redusere sykefraværet og samfunnskostnadene. For å skape slike verdier, trengs en sunn prestasjonskultur - en hybrid mellom helsekultur og prestasjonskultur, som nedenfor presenteres som et nytt begrep.

\section{Tidligere forskning og et tverrfaglig perspektiv}

Kapitlet legger til grunn et tverrfaglig perspektiv, som i hovedsak bygger på ulike retninger innen organisasjonsteori, organisasjonspsykologi, 
psykologi og helsefremmende ledelse. Et hovedargument er at både en sunn prestasjonskultur og de individuelle HR-driverne må pleies og utvikles for at ansatte, bedriften eller organisasjonen skal prestere. Organisasjonskultur, sunn prestasjonskultur, ansattes kompetanse, ansattedrivere (f. eks. engasjement, mental og fysisk helse), og deltakende lederskap blir argumentert for å være HR-relaterte drivere av organisatoriske prestasjoner i denne teoridelen (se også figur 1). Teoretiseringen utgjør bakgrunnen for de tre forskningsspørsmålene som fremmes. Den teoretiske drøftingen akkumuleres i figur 1, som illustrerer et teoretisk (idealistisk) bilde på hvordan organisatoriske prestasjoner kan forbedres i et HR-prespektiv. De blir fulgt opp under metode, funn, diskusjon og konklusjon.

\section{Organisasjonskultur og sunn prestasjonskultur}

Organisasjonskultur er en viktig HR-relatert driver for organisatoriske prestasjoner, som også vist i figur 1. Schein (1985) argumenterer for at organisasjonskultur består av artefakter, verdier, normer og lederes grunnleggende antakelser («sannheter/tankegods» om f.eks. en måte å løse bestemte oppgaver på). Artefakter kan være kontorer, kunst, språk, kleskode, historier, seremonier, ritualer og atferd (Schein, 1985; Wilson, 2001). I henhold til Denison (1990, 2000) består organisasjonskulturen av de fire målbare dimensjonene visjon/misjon/verdier, tilpasningsdyktighet, involvering og samhandling/samsvar. En positiv organisasjonskultur, bestående av medarbeidernes støtte for visjonen, misjonen og verdiene, sammen med involvering, tilpasningsevne og konsekvent samhandling over lang tid, vil ha en positiv innvirkning på bedriftens økonomiske resultater, effektivitet og lønnsomhet (Denison, 1990, 2000, 2001; Denison \& Mishra, 1995; Nikpour, 2017). Som en grunnleggende driver av organisasjonens prestasjoner har kulturen også en viktig påvirkningskraft på ansattes engasjement (Nikpour, 2017).

Verdier er viktige for organisasjonens identitet og organisasjonskultur (Bjerke \& Ind, 2007; de Chernatony \& Cottam, 2006; Ind \& Bjerke, 2007) og verdier blir levert av mennesker (Mellor, 1999). Basert på organisasjonens verdier, må ansatte prestere og levere gode produkter, tjenester og 
opplevelser for at organisasjonen skal bli forbundet med positive assosiasjoner og blir foretrukket fremfor andre alternativer (Bjerke, 2016; Bjerke \& Ind, 2007). Det underliggende i beskrivelsene er at kultur kan påvirke og bli påvirket av individer. Den kan sees på som en delt hukommelse formet av implementerte verder og tidligere erfaringer som styrer fremtidig handling. Den delte hukommelsen forsterkes og viderebringes gjennom dialog, konversasjon og historiefortelling. Som figur 2 illustrerer, representerer organisasjonskulturen fundamentet for utviklingen av en sunn prestasjonskultur, her forstått som en hybrid mellom helsekultur og prestasjonskultur.

Organisasjoner har muligheten til å etablere en støttende helsekultur for tilrettelegging av fysiske aktiviteter for ansatte og et helsefremmende miljø (Amlani \& Munir, 2014; Pronk \& Kottke, 2009). En helsekultur kan beskrives på tilsvarende måte som en organisasjonskultur, som kjennetegnes ved et kollektivt tankesett og handlingsmønster, formidlet formelt eller uformelt, basert på felles verdier. En helsekultur baserer seg også på felles verdier, hvorav enkelte av disse styrer atferden mot målet om å styrke ansattes helse (Golaszewski et al., 2008; Lin \& Lin, 2014). Helsekulturen fordrer et organisatorisk helsemiljø, basert på kulturelle faktorer som verdier, normer, berøringspunkter og ritualer, og strukturelle faktorer som fasiliteter, service og adminstrativ støtte (Golaszewski, Allen \& Edington, 2008). En helsekultur trenger helsefremmende planlegging, men må også evalueres underveis. Hoebbel, Golaszewski, Swanson \& Dorn (2012) diskuterer normer, verdier, sosial støtte, berøringspunkter og klima som hjelpende faktorer i utviklingen av en helsekultur. De ulike tilnærmingene til begrepet helsekultur viser bredde og overlapping, noe som kommer frem hos McLeroy, Bibeau, Steckler \& Glanz (1988), som presenterer en økologisk modell for helsefremmende intervensjoner. Her diskuteres både individuelle og sosiale faktorer, som kan ses i sammenheng med tidligere nevnte kulturelle og strukturelle elementer. Den økologiske modellen baserer seg på følgende faktorer: Intrapersonelle (kunnskap, holdning, atferd, ferdigheter osv.); mellommenneskelige (sosiale nettverk, sosiale støttesystemer osv.); institusjonelle (organisatoriske egenskaper, regler og forskrifter); fellesskapsrelaterte (relasjoner mellom organisasjoner og institusjoner); offentlige (lokale, statlige og nasjonale lover). 
Som nevnt over består en sunn prestasjonskultur av både helsekulturelle og prestasjonskulturelle faktorer. André de Waal (2007) hevder at kulturen til en høypresterende organisasjon er preget av blant annet et vinnende tankesett og utmerket kvalitet i alt i hva den foretar seg. I tillegg argumenterer Kaliprasad (2006) i en studie om prestasjonskulturer at ansattes kompetanse og kontinuerlig utdannelse, arbeidsgrupper og lederskap er suksessfaktorer for å prestere blant de absolutt aller beste i bransjen. Sullivan (2005) trekker frem HR-avdelingens ansvar for å utvikle en prestasjonskultur gjennom arbeid med HR-strategien. En slik strategi skal være fremtidsrettet, og må bestå at utviklingsprogrammer som setter de ansatte i stand til å påvirke hele organisasjonen og spesielt kortsiktige- og langsiktige mål. Det er likevel de ansattes deltakelse som er den viktigste forklaringsvariabelen for måloppnåelse for organisasjonen (Shahzad, Iqbal \& Gulzar, 2013). Deltakelse handler om å være involvert i organisasjonskulturen, og om engasjement i en individuell kontekst (se figur 1). Basert på forståelsen av organisasjonskultur, helsekultur og prestasjonskultur definerer jeg i denne sammenheng en sunn prestasjonskultur som

En type organisasjonskultur som kjennetegnes av felles helseverdier, normer, ritualer, fellseskapsfølelse og et støttende miljø som skal bidra til å nå sosiale og helserelaterte mål, slik at ansatte settes i stand til å prestere blant de beste i bransjen/sektoren gjennom felles vinnende tankesett og ansatteatferd, uten mentale eller fysiske belastninger.

I avsnittene over har jeg teoretisert omkring organisasjonskultur og utviklet definisjonen av en sunn prestasjonskultur. Det første forskningsspørsmålet handler om hvordan norske bedrifter, hvor det er krav om måloppnåelse og prestasjoner, tenker preventivt i forhold til ansattes helse.

Forskningsspørsmål 1: Er det indikasjoner på at norske bedrifter utvikler en helse-

kultur eller en sunn prestasjonskultur?

\section{Individuelle HR-drivere av organisatoriske prestasjoner}

Læring og utvikling har en positiv påvirkning på ansattes trivsel, produktivitet og lønnsomhet (Watkins \& Marsick, 2003). Gjennom utvikling 
og transformasjonsprosesser blir disse individuelle ressursene omdannet til en kollektiv kompetanseressurs, som kan settes i sammenheng med bedriftens prestasjoner (Ployhart \& Moliterno, 2011). Selv om de ansattes individuelle kompetanser må utvikles og pleies, er det kanskje den kollektive kraften som ligger i en organisasjonskultur som er hoved-driveren til en sunn prestasjonskultur (som vist i figur 1).

Ansatte-drivere består av faktorer som påvirker enkeltindividets atferd og prestasjoner på jobb. Disse driverne, som er sammenkoplet med organisasjonskulturen og sunn prestasjonskultur (se figur 1), er blant annet engasjement, mental og fysisk helse. Helse har blitt definert av Verdens helseorganisasjon (WHO) som tilstedeværelse av fysisk, mentalt og sosialt velvære (Tetrick \& Quick, 2003). Jones, Molitor og Reif (2019) anslo at helsefremmende aktivitetsprogrammer på arbeidsplassen (de blir kalt velværeprogrammer i USA og består antagelig av mindre fysisk aktivitet og mer behandling) tilbys til over 50 millioner amerikanske arbeidere. Til tross for at noen studier viser blandede resultater fra slike programmer (Baicker, Cutler, \& Song, 2010; Berry, Mirabito, \& Baun, 2011) tyder mye på at godt utformede og gjennomførte programmer kan gi økt helsetilstand og økonomiske fordeler (Conn, Hafdahl, Cooper, Brown \& Lusk, 2009; Downward \& Rasciute, 2011; ten Brummelhuis \& Bakker, 2012; Goetzel et al., 2014). HR-avdelingen må derfor utvikle et konkurransefortrinn på ledelse av menneskelige ressurser og/eller arbeidsstyrkens produktivitet (Sullivan, 2005).

I en tidligere studie har jeg (Bjerke, 2016) argumentert for en type konseptuell modell som viser de tre hovedkomponentene av ansattes mentale helse, nemlig subjektivt velvære, arbeidsvelvære og psykologisk velvære. Modellen vist i figur 1 tar utgangspunkt i kunnskap om ansattes generelle velvære (Page \&Vella-Brodrick, 2009) og trivsel på arbeidsplassen (Grant $\&$ Ashford, 2008). Tilfredshet med livet og generell lykkefølelse utgjør subjektivt velvære, og arbeidsvelvære består av jobbtilfredshet og lykkefølelse for jobben. Jobbtilfredshet er definert som en følelse som kjennes når vi opplever psykologisk vekst gjennom prestasjon, anerkjennelse, arbeidsinnhold, ansvar og avansement (Herzberg, 2003). Selv-aksept, positive relasjoner med andre, mestring av miljøet, autonomi, personlig vekst og mening med livet er elementene i psykologisk velvære. Det er 
dokumentert positive sammenhenger mellom jobbtilfredshet, motivasjon og prestasjoner (Parker et al., 2003), og mellom sportsaktiviteter og følelsen av velvære (Downward \& Rasciute, 2011). Også lønnsstrategier og strategier for å skape meningsinnhold i ansattes jobboppgaver har en positiv innflytelse på jobbtilfredshet og engasjement (Luna-Arocas \& Camps, 2008), som igjen kan koples til bedret helse og velvære (Loehr, 2005). Disse funnene indikerer også en sammenheng mellom fysisk og mental helse.

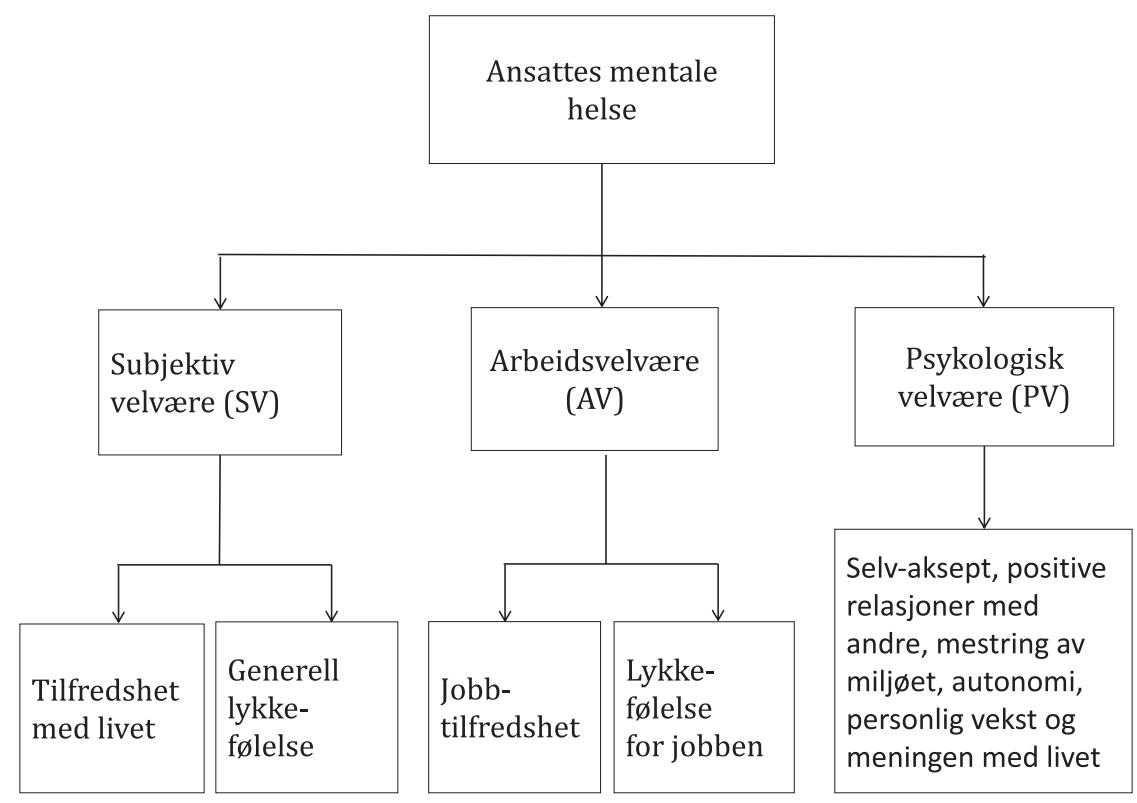

Figur 1 Ansattes mentale helse.

Kilde: Bjerke, 2016.

En studie med temaet «Gøy på jobben», som her er definert som en ansattdriver (se figur 2), viste at morsomme aktiviteter (konkurranser, sosiale arrangementer, «team building» og feiringer av arbeidsprestasjoner) kan ha en gunstig effekt på ansattes prestasjoner. Men «innpakningen av moroa» må være forenlig med organisasjonens strategi, resultater og de ansattes kompetanse (Tews, Michel \& Stafford, 2013). Gøy på jobben ble i en annen studie delt inn i de tre kategoriene morsomme aktiviteter, sosialisering blant kolleger og ledelsens tilrettelegging for gøy og moro. 
Studien konkluderte blant annet med at gøy på arbeidsplassen virker forsterkende på relasjoner mellom ansatte (Tews, Michel \& Allen, 2014). I tillegg har «moro på jobben» en positiv påvirkning på jobbtilfredshet (Karl, Peluchette, Hall-Indiana \& Harland, 2005).

Ifølge Loehr (2005) er fordelene ved ansattes engasjement og entusiasme større verdibidrag til arbeidsgiveren samt bedret fysisk helse og velvære. Ansattes engasjement kan skapes gjennom samkjøringen mellom lederskap, jobbinnhold og individuell kompetanse (Wildermuth \& Pauken, 2008). Bakker og Demerouti (2008) konkluderte med at engasjerte ansatte er mer kreative, produktive og forberedt på å legge inn en ekstra innsats. Arbeidsengasjement er positivt relatert til arbeidsglede, organisatorisk engasjement og god helse, og en helsekultur kan etableres ved å utvikle et organisatorisk helsemiljø (Golaszewski, Allen \& Edington, 2008).

Et organisatorisk helsemiljø og en sunn prestasjonskultur avhenger av deltakende lederskap som driver/påvirker utviklingen. Dette gjøres blant annet gjennom kommunikasjon om visjon, verdier og mål som er tydelig retningsgivende for ansatte (Bass \& Avolio, 1993; Schein, 1985). Bjerke og Ind (2007) understreker at ledere bør jobbe for å skape en kollektiv kraft på veien mot måloppnåelser, og mener ledere skal skape entusiasme omkring prosesser som skaper ny innsikt, energi og utholdenhet samtidig som de bør oppmuntre til intuisjon og sensitivitet $i$ møte med andres behov. Derfor kan deltakende lederskap være med på å utvikle en sunn prestasjonskultur. Engasjert, deltakende ledelse på flere nivåer er en avgjørende faktor for vellykkede helseprogrammer rettet mot ansatte (Berry et al., 2010). Ledere må dessuten være tydelige på retning og mål, vise evne til å lytte til andre og ta imot råd, for så å ta beslutninger basert på disse. Å være en deltakende leder forutsetter en god porsjon emosjonell intelligens og empati, slik at de kan dele meninger og skape meningsfulle relasjoner innenfor og utenfor organisasjonen (Bjerke \& Ind, 2007). Lederne bør derfor være fysisk til stede og bli oppfattet som en del av organisasjonen og ansattfellesskapet, slik at alle medarbeiderne står sammen om prosessen «living the brand» (Ind, 2001). Dermed skapes forutsetningene for at organisasjonen kan fremstå som en samkjørt enhet som leverer konsekvente budskap, løfter, produkt- og 
tjenesteopplevelser til kunder og andre interessegrupper (Bjerke \& Ind, 2007; Ind \& Bjerke, 2007).

I denne delen er det gjort greie for viktigheten av god helse på arbeidsplassen og relaterte individuelle HR-drivere for å prestere. Styrking av disse driverne bør være motiver for å tilrettelegge for fysisk aktivitet på arbeidsplassen. Hovedargumentet i dette kapitlet er at utviklingen av en sunn prestasjonskultur bremses, og dermed prestasjonene, hvis de ansattes mentale og fysiske helse ikke blir godt ivaretatt. Derfor er det interessant å stille spørsmål om hvordan og hvorfor noen norske bedrifter tilrettelegger for helsefremmende tiltak for ansatte.

Forskningsspørsmål 2: Hvordan og hvorfor tilrettelegger bedriftene fysisk aktivitet på arbeidsplassen?

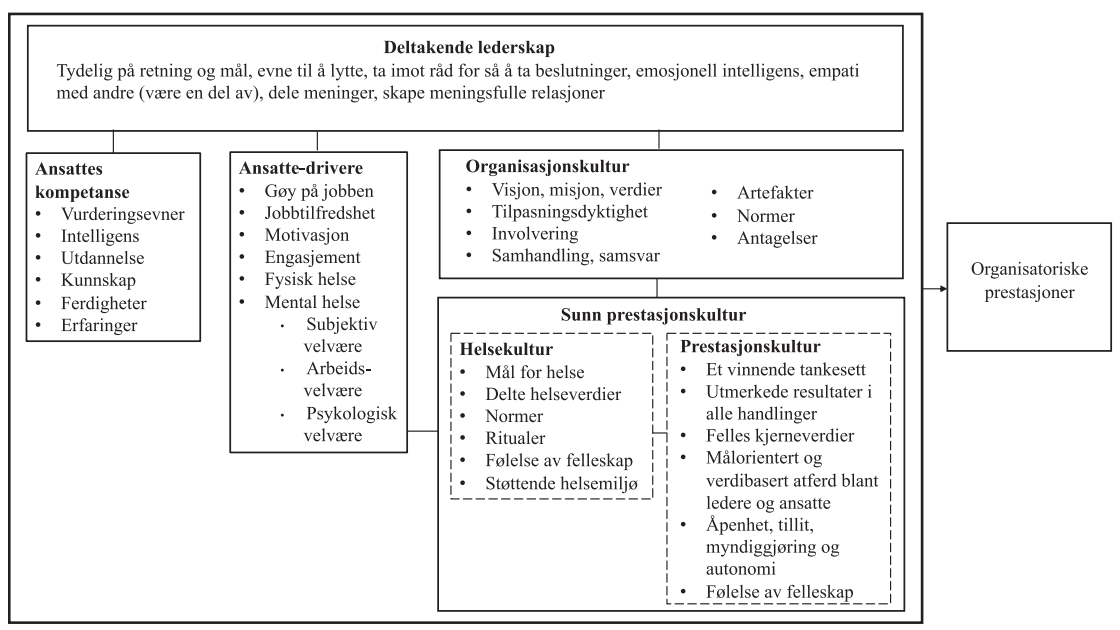

Figur 2 Sunn prestasjonskultur og individuelle HR-drivere av organisatoriske prestasjoner.

\section{Strukturelle faktorer ved tilrettelegging av fysisk aktivitet}

I en undersøkelse av fysiske helsefremmende aktiviteter på arbeidsplassen blant arbeidstakere som jobbet og bodde utenfor hjemmet (pendlere), konkluderte forskerne med at en rekke strategier som promoterer og kommuniserer tilbud av fysisk aktivitet på arbeidsplassen kan forbedre de 
ansattes fysiske aktivitet (Crespo, Sallis, Conway, Saelens \& Frank, 2011). Jeg har tidligere nevnt Golaszewski, Allen \& Edington (2008) sin konseptuelle modell relatert til helsefremmende programmer på arbeidsplassen. Her trekkes viktigheten av støttende faktorer trekkes frem, og strukturelle faktorer blir ansett som viktigst. Støttende strukturelle faktorer, som for eksempel en egen helseportal, ble hevdet å ha en motiverende påvirkning på ansatte, noe som igjen bidro positivt til ansattes helsetilstand. Bjerke og Elvekrok (2020) konkluderte med at helseportalen til Aker, akeraktiv.no, hadde en signifikant påvirkning på ansattes motivasjon til å drive med fysisk aktivitet. Giddens, Leidner \& Gonzalez (2017) fant at skritt-tellere, som støtte i et velværeprogram på arbeidsplassen, har en positiv innvirkning på ansattes bruk og trivsel, noe som indikerer et positivt forhold mellom bruk av helseteknologi og helsetilbud. Brynjolfsson, Hitt og Yang (2002) understreket at helsefremmende prosjekter trenger ledernes oppmerksomhet, og dokumenterte at en ansattportal/helseportal forbedret kommunikasjonen om helserelatert innhold. Anderson et al. (2009) oppdaget at det er mulig å forbedre ansattes vektstatus ved å endre ansattes atferd (fysisk aktivitet, matvalg og kosthold). Price, Bray \& Brown (2017) gjennomførte en studie om kantinemat og informasjon om maten på en arbeidsplass med utgangspunkt i sammenhengen mellom diett og helse. De konkluderte med at ansatte var åpne for tekniske løsninger (mobilapp) som kunne gi informasjon om næringsinnhold og føre til engasjement. Det betyr at innholdet og teknologiske støtteverktøy i helsefremmende programmer bør rettes mot ansatte. Det er derfor interessant å stille spørsmål om hvilke fasiliteter og forhold noen norske bedrifter tilbyr i tilretteleggingen av fysisk aktivitet på arbeidsplassen. Dermed blir det siste forskningsspørsmålet følgende:

Forskningsspørsmål 3: Hva slags fasiliteter og strukturelle faktorer tilbys ansatte?

Som nevnt over, representerer begrepene og de foreslåtte sammenhengene i figur 2 et idealistisk bilde på hvilke HR-relaterte drivere som står bak organisatoriske prestasjoner. Ved å svare på de tre forskningsspørsmålene vil det også bli avklart om hvordan praksisen er i overensstemmelse med eller avviker fra det teoretiske bildet. Nedenfor beskrives metoden som ble benyttet for å svare på forskningsspørsmålene. 


\section{Metode}

\section{Design, datainnsamling og analyse}

En konseptuell tilnærming med teoretisering og et eksplorerende design ble anvendt for å søke empirisk støtte til en foreslått teoretisk modell (Creswell, Clark, Gutmann \& Hanson, 2003; Bjerke \& Kirkesaether, 2020). Kvalitativ data ble også samlet inn for å gi svar på «hvordan» og «hvorfor» angående tilrettelegging av helsefremmende fysiske aktiviteter på arbeidsplassen (Yin, 2017). Det ble benyttet et multippelt casedesign (Creswell et al., 2003) med de fire mini-casene Schibsted/VG, Findus, Gjensidige og Wilhemsen, og en sammenlikningstilnærming for å undersøke mulige ulikheter/likheter mellom dem (Yin, 2017). Bedriftenes helsefremmende programmer og tilrettelegging var objektene som skulle analyseres (Baxter \& Jack, 2008). En trianguleringsmetode (en kombinasjon av datainnsamlingsmetoder) med intervjuer og mini-caser ble anvendt for å styrke troverdigheten og påliteligheten til studien (Golafshani, 2003; Morrow, 2005). For å oppfylle pålitelighetskriteriet (Morrow, 2005; Shenton, 2004) og for å utvikle en troverdig representasjon (Shenton, 2004) av aktivitetstilbudet til ansatte, ble både etablert teori, funn fra de fire mini-casene og fem forskjellige informanter brukt som kilder.

Basert på litteraturgjennomgangen ble det utviklet en semistrukturert intervjuguide. Hovedspørsmålene i intervjuguiden handlet om tilgjengelige fasiliteter, helsekultur og prestasjonskultur med oppfølgingsspørsmål omkring strategier/HR-strategi, programmer/tiltak, ritualer, normer, verdier og brukere. Guiden ble anvendt for å fange opp ulike temaer, beskrivelser og svar (Creswell \& Creswell, 2017). Intervjuene ble gjennomført «online» (teknologi fra Zoom.us) med et utvalg av ledere (Farrelly, 2013) som var ansvarlige for bedriftenes fysiske aktivitetsprogram og HR-funksjoner: en eventansvarlig og kontorsjef, en leder for HR og gruppefunksjoner, en leder for fasiliteter og eiendom, en HR-direktør og en forretningsleder i salg. Intervjuene varte 60 minutter eller mer. De ble tatt opp med bruk av Zoom-teknologien, og deretter transkribert for å sikre pålitelighet (Spiggle, 1994; Yin, 2013).

Dybdeintervjuene ble fulgt opp av kommunikasjon via e-post for å få tilleggsinformasjon som informantene skulle innhente og for å få svar på 
uavklarte spørsmål som en valideringsprosedyre (Farrelly, 2013). Temaene (koder $\mathrm{i}$ analysen) som utgjorde sammenlikningsgrunnlaget var tilrettelegging av fysiske fasiliteter, helsekultur, prestasjonskultur, helsefremmende tiltak, programmer, mål, normer, verdier, tilbud, brukere/ oppslutning og effekter/verdiskapning. Disse ble anvendt som forhåndsdefinerte koder for analysen av transkriberingene for å styrke valideringen (Spiggle, 1994). Under analysen av dataene ble det søkt etter likheter/ ulikheter, beskrivelser og utsagn som kunne koples til de pre-definerte kodene (Creswell \& Creswell, 2017).

Tilsendt sekundærdata som informasjonsmateriale om programmer, eksempler på intranettsider, tilbud av konkrete fysiske aktiviteter og fasilitetene ble analysert (Baxter \& Jack, 2008). Samme koder ble brukt for å videreføre den tematiske analysen, som foreslått av Braun, Clarke og Weate (2016). Dokumentanalyse er nyttig fordi dokumenter er stabile, og de beskriver en rekke aktiviteter over en lengre periode (Yin, 2013). Kombinasjonen av dokumentanalysen med analyser av intervjuer styrket troverdigheten og påliteligheten til casestudien (Golafshani, 2003; Morrow, 2005). Studien og kapitlet er utviklet i et tverrfaglig perspektiv, der et av målene er å utvikle, legitimere og forklare teoretiske sammenhenger (Glaser \& Strauss, 2017). Som en kritisk bemerkning til metoden er det viktig å understreke at flere caser, og spesielt flere informanter, ville kunne styrke studiens pålitelighet og troverdighet.

\section{Casene}

\section{Findus}

Findus er en del av Nomad Foods, som er Europas største leverandør av frossenmat. Selskapet, som er 2,54 ganger større enn dets største konkurrent, har over 4600 ansatte, eier 13 ulike produksjonssteder og er distributør av mat til 17 land. Konsernet omsetter for 2,27 milliarder euro årlig. Markedsandelen i Norge med merket «Findus» er 30,3 \%. Findus' visjonog verdihjul synliggjør en organisasjonskultur som skal preges av innovasjon, omstilling og utvikling, effektiv ledelse og merkevarebygging (se figur 1, vedlegg). Findus dekker ansattes eksterne treningsmedlemskap med opp til $200 \mathrm{kr}$, og har forsikringsordninger for skader, fysioterapi og 
kiropraktorer. Selskapet tilbyr fleksibel arbeidstid og tillater de ansatte å trene fritt $\mathrm{i}$ arbeidstiden så lenge arbeidet $\mathrm{i}$ løpet av en arbeidsuke utføres. Bedriften har ikke egne arenaer for fysisk aktivitet, så ansatte må rydde bort stoler og bord i kantinen for å gjennomføre treningsøkter.

I løpet av sommeren 2020 ble selskapets hovedkontor flyttet inn i nye lokaler, der selskapet deler treningsfasiliteter med andre bedrifter (treningsrom, spinning-rom og sykkelparkering). I tillegg har de egne verandaer som skal brukes til yoga-økter. Findus tilbyr de ansatte grønne hverdager med kjøttfrie måltider, gratis frukt og kantinemat med sunn og variert kost. Findus har benyttet et enkelt excel-ark for timeregistrering på gruppetimer (se tabell $1 \mathrm{i}$ vedlegg), samt intranettet og e-post som brukes til informasjonsutveksling. Findus Norge har det siste året implementert et eget helseprogram («Our Well Way») med aktivitetstilbud, gruppetimer med innleide instruktører og tre interne eventer inklusive kunnskapsfremmende seminarer med tre temaer. Hovedmålet er at fysisk helse skal være et tema gjennom hele året.

I Findus jobber vi for å hjelpe familier med å spise litt sunnere og smartere hver dag - og vi mener at denne mentaliteten starter på arbeidsplassen. Vi anser helse og velvære som et viktig utgangspunkt for suksess og vi har derfor lansert «Our Well Way» - vårt helt egne helse- og velværeprogram. Dette programmet innebærer blant annet temaer som fysisk aktivitet, ernæring, mental helse og søvn. (Findus, 2020)

Ijanuar-apriler temaet «nutrition and good food», mai-augusthar «coping with stress and mental health» på agendaen, og i september-desember er temaet «wellness and happiness». «Our Well Way»-programmet fungerer også som bedriftens hovedplattform for å informere og bevisstgjøre ansatte om bedriftens grunnleggende helserelaterte verdier.

\section{Schibsted/VG}

Schibsted er et internasjonalt selskap som forvalter flere kjente, digitale forbrukermerker. Konsernet har til sammen over 5000 ansatte (i Norge, Danmark, Finland, Sverige og Polen). I Norge eier Schibsted fire av Norges ti største aviser: VG, Aftenposten, Bergens Tidende og Stavanger Aftenblad (SNL). Schibsted/VG har de fire kjerneverdiene integritet, 
innovasjon, samhold og konkurransedyktighet. I det ene lokalet til Schibsted/VG i Akersgata 55, har selskapet 1200 ansatte. Dette lokalet har et stort treningssenter i kjelleren, som inkluderer to styrkerom og en treningssal. Styrkerommet disponeres til blant annet yoga-timer, spinning (et par sykler er tilgjengelige), eller andre aktiviteter dersom de ansatte ønsker det. Ansatte kan også benytte SATS sine lokaler rett over veien for å delta i for eksempel spinning-timer. Det ble lagt opp til et ukentlig SATS-tilbud men så kom korona-pandemien. Ansattkantinen legger opp til ulike temaer i løpet av en uke, som for eksempel grønne dager. Alle ansatte får gratis frukt.

Schibsted/VG har bedriftsavtale med SATS. Innleide instruktører holder treningstimer flere ganger i uken, og de ansatte kan delta gratis. De får helseforsikring og tilgang til en tilhørende app som kan brukes for å bestille legetime, fysioterapeut og kiropraktor. I tillegg tilbys massasje i Akersgata mot en egenandel på $200 \mathrm{kr}$ per gang. Ansatte kan bestille så mange timer de ønsker. Schibsted/VG har en stor kantine, som rommer alt fra 600-900 ansatte. Regelmessige temadager med ulike tema, som for eksempel «grønne dager», legges til kantinen. Alle ansatte får gratis vann, kaffe og frukt. Schibsted har en egen intranettside hvor ansatte kan se oppsatte treningstimer, aktiviteter, kampanjer, tilbud og melde seg på til aktiviteter. Nettsiden er basert på Google-teknologi, som gjør det enkelt å koble til ulike enheter. Interne konkurranser kommuniseres også gjennom denne nettsiden, samt andre generelle hendelser og informasjon knyttet til helse og kropp. For uformell kommunikasjon om fysiske aktiviteter brukes også plattformen Slack.

\section{Gjensidige}

Gjensidige skriver om seg selv at selskapet i mer enn 200 år har tilbudt produkter ment for å sikre liv, helse og verdier. Selskapets visjon tar sikte på å være et ledende skadeforsikringsselskap, både i Norden og i Baltikum, og legger vekt på en høy grad av kundeorientering i kombinasjon med kostnadseffektivitet. A ta bærekraftige valg og løsninger fremstår som en viktig forutsetning for en langsiktig verdiskapning (Gjensidige, u.å.). Forsikringsselskapet har 30-35 kontorer i Norge med hovedkontor i Oslo. Gjensidiges gjeldende konsernstrategi for de 
nærmeste årene signaliserer et fokus på teknologi, urbanisering, klimaog miljøutfordringer, reguleringer og spesielt helse. Derfor settes det strenge krav til sunn mat og grønne måltider i kantinen, hvor både eksterne aktører og egne ansatte arbeider. Gjensidige har omtrent 1100 ansatte fordelt på to lokasjoner i Oslo. Alle har tilgang til hovedkontorets treningslokaler, som blir omtalt som et av Oslos beste treningsanlegg internt i bedrifter. Der er garderober med dusj og tilhørende badstue, og en stor sykkelparkering for de som sykler til jobben. Garderobene er utstyrt med 260 skap de ansatte kan benytte seg av både før og etter en treningsøkt. Spinning-salen har plass til 16 personer, og ansatte kan trene i en stor gymsal på $28 \times 22$ meter som blir delt med selskapet VY. Det meste som hører inn under fysisk aktivitet blir lagt ut på Gjensidiges intranett. I tillegg får ansatte informasjon via oppslag på dører og tavler, samt kalenderinnkalling via mail. Gjensidige benytter seg av innleide instruktører til både styrkecamp og yogaøkter en gang i uken. Selskapet tilbyr fleksibel arbeidstid. Gjensidige-informanten forteller at en ansatt kan gå ned og løpe en tur på mølla når det passer og ta igjen tapt arbeidstid senere.

\section{Wilhelmsen}

«Our ambition is to shape the maritime industry. Through innovation, expertise, quality products, and services we area ble to meet the challenges and needs of the world's global fleet» (Wilhelmsen Group, u.å.).

Wilhelmsen Group presenterer seg selv som et internasjonalt logistikk- og maritimselskap som holder til i 74 ulike land og har over 21000 ansatte. Wilhelmsen Norge holder til på Lysaker, hvor de har over 300 ansatte. I kantinen er det ansatt egne kokker og kantinepersonell. Det stilles høye krav til servering av sunn, grønn og næringsrik mat med faste vegetardager. Ansatte har fleksibel arbeidstid med et stemplingssystem, slik at de kan disponere arbeidstiden fritt.

I treningslokalene er det flere fasiliteter som gymsal, styrkerom og tilknyttede garderober. Wilhemsen har bedriftsavtale med SATS, som tilbyr de ansatte medlemskap til rabatterte priser. Instruktører fra SATS leies inn for å lede yoga-, «body pump»- og dansetimer med tilbud av salsa- og swingkurs i bedriftens egne lokaler. Et eget idrettslag (WIL) administrerer 
treningstilbud, og gruppetimene og får midler til helseformålet årlig. For intern helsekommunikasjon bruker bedriften en Teams-side med en egen portal hvor informasjon om treningstilbud, idrettsarrangementer og salg av sportsutstyr publiseres. WIL tilbyr følgende aktiviteter: Alpin, sykling, golf, high and low, kajakk, seiling, innebandy, fotball, yoga, saltrening (body pump, belastning osv.). I tillegg har idrettslaget ansvaret for forvaltningen av firmahytter, kulturtilbud og årsfest. WIL har også arrangert selvforsvarskurs og dansekurs.

\section{Funn}

\section{Forskningsspørsmål 1: Er det indikasjoner på at norske bedrifter utvikler en helsekultur eller en sunn prestasjonskultur?}

På direkte spørsmål om bedriftene benytter seg av begrepene helsekultur og prestasjonskultur, kom det frem at prestasjonskultur var et ord som ble brukt av ledere i ulike sammenhenger. Følgende sitater fra tre av bedriftene bekrefter bruken: «Ja, det kan jeg love deg, Ja, absolutt. Ja, det gjør vi. Det er akseptert». Inntrykket er at begrepet prestasjonskultur nevnes i situasjoner der det snakkes om bedriftens mål og ansatte måloppnåelse, og at de ansatte oppfatter det som et kjennetegn på organisasjonskulturen. Informantene var samstemte $\mathrm{i}$ at de ansatte ikke så ut til å reagere negativt på bruken av begrepet. Findus er også en organisasjon som er orientert mot mål, spesielt salgsmål. «Det at vi presterer er bra og at det går bra med selskapet. Men vi er opptatt av helse og kultur». Informanten understreket at det skulle være attraktivt å jobbe i selskapet, at ansatte skal føle at de er med på mer enn bare jobben, at de har lyst til å være der over lang tid og har det gøy på jobben.

Informantene ble stilt spørsmål som kunne indikere en form for helsekultur eller en sunn prestasjonskultur (helsemål, helseverdier, normer, ritualer, støttende miljø). Bedriftene gjennomfører felles fysiske aktiviteter i pausene som rutiner og som en type norm for hvordan arbeid kan brytes opp. Findus praktiserer gåturer i pausene, og de ansatte tar initiativ til styrkeøvelser som et «avbrekk» fra arbeidsoppgaven. «Planken et 
minutt når jeg blir trøtt kl. 14, for da klarer jeg meg til fire». Gjensidige bevisstgjør ansatte på hvor mye tid som «sløses bort» på møtevirksomhet. Forsikringsselskapet oppfordrer til korte, gjerne stående møter, eller mer uformelle møter i kantinen. De ansatte får tilbud om «energipauser» i regi av HMS med samlinger i en sosial sone hvor de gjennomfører en kort fysisk økt. Schibsted/VG og Wilhelmsen understreker at deres møter er tradisjonelle. Alle bedriftene tilbyr ulike felles aktivitetstimer bestående av for eksempel sirkeltrening og yoga. Wilhelmsen skiller seg ut her ved å tilby dans som en felles morsom fysisk aktivitet. En informant forteller: «Vi har hatt swingkurs før, det var populært. Det var mange som meldte seg på».

Findus følger med årlig på hvor mange ansatte som benytter seg av helseforsikringen deres i tillegg til sykefravær, «turnover» og hvor mange som benytter seg av bedriftsavtalen med treningssenteret SATS. «Når det gjelder hvordan de fysiske tilbudene påvirker produktiviteten i selskapet har vi ingen konkrete tall, men det går bra med selskapet».

Schibsted/VG benytter plattformen Schibsted Life, som kan gi oversikt over antall påmeldte til treninger, men ellers gjennomføres ikke systematiske analyser. Likevel gir Schibsted/VG uttrykk for at problemstillingen omkring verdiskapning i forhold til ansatte-drivere er interessant å vurdere: «Det høres ideelt ut, men vi er ikke der nå, nei».

Gjensidige gjennomfører månedlige medarbeiderundersøkelser som inneholder spørsmål om lønn, oppfølging og fysiske betingelser. Undersøkelsen gir de ansatte muligheten til å ytre tilbakemeldinger på fasiliteter og tilbud. Forsikringsselskapet evaluerer ikke ansattes helse eller andre ansatte-drivere (se figur 1), men opplyser om lavt sykefravær.

Wilhelmsen kartlegger ansattes helse med en årlig helsesjekk med blant annet blodprøver og sjekking av syn og hørsel. Helsesjekken avdekker utviklingen i antallet ansatte som røyker eller lider av hjerteog karsykdommer. En massør kommer til selskapet 3 dager i uken for å ta hånd om anspente muskler i rygg og nakke. Selskapets sykefravær ligger på omkring to prosent, som selskapet tror er et resultat av «et godt og variert tilbud, god mat, gode aktiviteter og sosiale tilbud». Likevel, verdiskapningen som en konsekvens av tilbudene måles ikke, og er ikke tallfestet. 


\section{Forskningsspørsmål 2: Hvordan og hvorfor tilrettelegger bedriftene fysisk aktivitet på arbeidsplassen?}

Basert på det teoretiske resonnementet og begrepet ansatte-drivere vil den mest grunnleggende formen for støtte til utvikling av en sunn prestasjonskultur være at helsefremmende tiltak er forankret i bedriftens HR-strategi. Vi stilte derfor spørsmål om tilbudene er forankret i en HR-strategi. Av casebedriftene som ble undersøkt er det kun Findus som har forankret de felles fysiske aktivitetene i ledelsen og i en type HR-strategi gjennom programmet «Our Well Way». «Vi er et team og er tre stykker som driver dette i sammen. Jeg som forretningsleder i salg er ambassadør og jobber tett med HR-forretningspartner og HR-konsulent». Findus-informanten opplyser om at helse og sunnhet er koblet til selskapets kjerneverdier og merkevaren. Schibsteds organisering av de fysiske aktivitetene er derimot basert på frivillighet. «Vi jobber frivillig i systemet, jeg får ikke ekstra betalt for det. Helsebegrepet er ikke nevnt, men det ligger implisitt i verdiene. Vi kunne nok vært flinkere på å få det nedfelt». Gjensidige har etablert en type «intern organisasjon» som bedriften har navngitt «Gjensidige Sport», som ledes av frivillige ansatte med et styre. Enheten består av 15-20 aktivitetsgrupper som gir ulike varierte tilbud til de ansatte, til tross for at tilbudene ikke er et resultat av noen form for strategier. En informant hos Gjensidige forteller: «Skal ikke si det er en nedfelt strategi, men [...] Det er en del av vår konsernstrategi/HR-strategi med henhold til forebyggende tiltak, men det står ikke nedskrevet». Wilhelmsen har et idrettslag som administreres av frivillig ansatte. «Vi har et variert tilbud, og det er opp til de ansatte å bruke det. Det er ikke direkte i strategien. Det å ha det godt på jobb har alltid vært en prioritering. Vi bruker mye penger på aktiviteter for de ansatte».

Informanten fra Findus mener at å ha en helsestrategi i kombinasjon med engasjerte frivillige, som drar i gang ulike opplegg, har bidratt til at flere ansatte har deltatt på flere aktiviteter. HR Business Partner understreker at ledelsen setter fokus på helse og velvære for å motivere ansatte til å delta på felles aktiviteter. Dermed blir det poengtert at engasjerte ledere kan fremstå som rollemodeller. Findus nevner at engasjementet 
blant noen av avdelingslederne med fordel kunne vært høyere. «Det er vanskelig å motivere og pushe andre til å delta når ikke lederen deltar selv». Informanten fra Gjensidige opplyser om at ledere stiller seg ulikt til hvorvidt trening og helse bør prioriteres. «Ledere er jo ulike. Noen ville sagt det er greit, andre ville rynket på nesen ...»

Findus forklarer at gjennom «Our Well Way»-programmet og tre fokusområder i året er målet å styrke kunnskapen om helsefordelene ved blant annet fysisk aktivitet og et sunt kosthold. Eksterne fagfolk bidrar med presentasjoner og foredrag. Findus utfører målinger som viser hvem som benytter seg av tilbudene. Det viser seg at de som i utgangspunktet er fysisk aktive er de som deltar på fysiske aktiviteter i jobbsammenheng, men ser tendenser til mulig endring: «Erfaringen vår etter 'lockdown' i mars 2020 på grunn av korona-pandemien, er at vi har fătt med flere ansatte enn de som normalt sett har vært fysisk aktive».

Informanten fra Wilhelmsen indikerer også de samme hovedtrekkene som hos Findus: «Det er vanskelig å få med de som ikke trener, det er stort sett de som trener på fritiden som også trener på jobb». Videre forklarer informanten at tilrettelegging av lavterskeltilbud er viktig for å motivere så mange ansatte som mulig: «Derfor satte vi i gang dans, vi tenkte salsa var gøy». Dette tilbudet ble beskrevet som mer populært enn andre tradisjonelle fysiske aktiviteter. Likevel tror informanten at det er en begrenset effekt på lavterskeltilbud. Informanten fra Gjensidige antyder også usikkerhet omkring effekter fordi det mangler et system for målinger: «Det er alltid noen som synes alt med fysisk aktivitet og helse er uinteressant, mens andre trener flere ganger om dagen og i tillegg sykler hjem».

\section{Forskningsspørsmål 3: Hva slags fasiliteter og strukturelle faktorer tilbys ansatte?}

I presentasjonen av casene Schibsted/VG, Gjensidige og Wilhemsen har vi sett at bedriftene tilbyr gode fasiliteter med gymsaler, styrkerom, spinning-saler, sykkelstativer og garderober. Findus skal flytte til nytt bygg i løpet av sommeren 2020 med tilsvarende fasiliteter. Schibsted/VG, Gjensidige og Wilhemsen har avtaler med innleide instruktører, og Wilhemsen tilbød også vellykkede dansetimer. Bedriftene vektla tilbud 
av helseforsikringer, enkel tilgang til behandling og massasje, fleksibel arbeidstid hvor hver enkelt bestemmer egen treningstid samt tilbud av et sunt og variert kosthold i kantinen. Gratis frukt, grønne måltider og vegetardager er gjengangere blant casebedriftene.

Som en del av strukturelle forhold ble det spurt om kommunikasjonsfunksjoner omkring aktivitetstilbudene. Findus har et eget intranett, men det blir ikke benyttet i forbindelse med tilbud av fysiske aktiviteter. Informanten forklarer at de kanskje vil kunne tilby en app etter at de har byttet lokaler. Et forsøk med ExCel- ark hvor ansatte skulle registrere trening ble ikke vellykket. Schibsted har konsept Schibsted Life (del av intranettet for hele konsernet), som også blir brukt til å formidle informasjon om sosiale sammenkomster og kampanjer. I tilknytning til Schibsteds helseforsikring kan ansatte laste ned en mobil-app som kan brukes for å bestille timer til lege, fysioterapeut og kiropraktor. For uformell dialog mellom fysisk aktive ansatte brukes delings- og kommunikasjonsapplikasjonen «Slack». Gjensidige tar utgangspunkt i timeplaner for felles aktivitetstilbud, og benytter seg av kalenderinnkalling via Outlook. Informasjon i papirformat om trening og helse blir av og til satt opp på dørene i kontorlokalene. Wilhelmsen bruker en portal via Microsoft Teams, men har imidlertid ikke en løsning med påmelding til trening eller informasjon om helse og kosthold.

\section{Diskusjon og konklusjon}

\section{Diskusjon}

Modellen i figur 2 over foreslår som tidligere forklart et idealistisk (teoretisk) bilde på at en sunn prestasjonskultur og individuelle HR-drivere kan fremme organisatoriske prestasjoner. Jeg argumenterer blant annet for at ansattes mentale og fysiske helse og en sunn prestasjonskultur er viktige forutsetninger for sterke prestasjoner. Basert på det idealistiske bildet, forskningsspørsmålene og funnene fra innsamlede kvalitativ data, ser det ut til at teorien ligger noe foran praksisen til disse fire case-selskapene. Likevel gjenspeiler praksisen flere elementer i det teoretiske landskapet. Med utgangspunkt i forskningsspørsmål 1 ser vi at alle bedriftene har til 
felles at de hevder å være karakterisert i form av prestasjonskultur. Det er flere indikasjoner på en slik kultur. Selskapene ser ut til å være målrettet, og de implementerer verdiene tillit, frihet og autonomi (de Waal, 2006), noe som uttrykkes gjennom den fleksible arbeidstiden. Dessuten kommer det frem at Findus er veldig fokusert på salgsmål. Kantinene tilbyr gratis frukt, sunn mat, vegetariske dager og måltider, noe som bidrar til ansattes helse (Anderson, 2009). Ved å tilby sunn og velsmakende kantinemat og fysiske aktiviteter på arbeidsplassen, basert på sunnhetshetsverdier, er det indikasjoner på at selskapene beveger seg mot en helsekultur (Golaszewski et al., 2008; Lin \& Lin, 2014). Dessuten kan det se ut som mulige negative konnotasjoner knyttet til prestasjonskultur blir tonet ned med tiltak som arbeidstidsfleksibilitet, tilbud om delikate, sunne lunsjer og massasje. Massasjetimer, som Schibsted og Wilhemsen tilbyr, skal løse opp spenninger forårsaket av arbeidsstress, som kan være konsekvensen av hektiske arbeidsdager (Crawford, LePine \& Rich, 2010; Kamarck et al., 2005). Teorien slår også fast at stress påvirker ansattes fysiske og psykiske helse negativt (Bono et al., 2013). Fundert på bedriftenes verdier tilbyr de også fysiske aktiviteter og fasiliteter med høy standard som støttende strukturelle faktorer (Golaszewski, Allen \& Edington (2008). Helseprogrammene består av ulike gruppeaktiviteter som yoga, sirkeltrening, dans og en rekke lagidretter.

Tatt i betrakning disse funnene kan det hevdes at tre av selskapene har utviklet et helsefremmende miljø (Amlani \& Munir, 2014; Pronk \& Kottke, 2009), men ennå ikke en helsekultur (Golaszewski et. al., 2008; Hoebbel et al., 2012). Findus kan imidlertid argumenteres for å ha en helsekultur (Golaszewski, Allen \& Edington, 2008) på grunn av koblingen til HR-strategien, helseverdiene, «Our Well Way» -programmet, de tre årlige fokusområdene, og målet om å forbedre ansattes forståelse av helsemessige fordeler ved fysisk aktivitet og et sunt kosthold (Anderson, 2009). Samtidig er det tilstrekkelige indikasjoner for å hevde at Findus er i en prosess med å utvikle en sunn prestasjonskultur. I tillegg er det viktig å merke seg at både casene så vel som teorien avslører at felles fysiske aktiviteter og helseprogrammer kan bidra til sosial interaksjon (HoltLunstad et al., 2015), forbedrede ansattforhold (Tews, Michel \& Allen, 2014), styrket helse (Anderson et al., 2009; Pronk \& Kottke, 2009), og 
moro på jobben (Tews, Michel \& Stafford, 2013), som igjen kan føre til utvikling av en sunn prestasjonskultur.

Når det gjelder hvordan aktivitetene er organiserte og deltakelsen, som er temaet i forskningsspørsmål 2, ble det hevdet at de som trener konsekvent på jobben er de samme som de som allerede trener hjemme. Disse ansatte er også representert av de frivillige som administrerer organiseringen av fysisk aktivitet på arbeidsplassen. I følge Berry et al. (2010) er engasjerte ledere avgjørende for vellykkede helseprogrammer rettet mot ansatte. Findus er et godt eksempel, med markedssjefen og HR-sjefen som rollemodeller. Som nevnt over, skiller Findus seg noe fra de andre bedriftene med sitt HR-forankrede opplegg. Men også fordi et team bestående av ansatte i ledende roller har ansvar for planlegging og implementering av helseprogrammet «Our Well Way», og slik fremstår som gode forbilder og representerer deltakende ledelse (Ind \& Bjerke, 2007). Findus er den eneste bedriften av fire som har utviklet og organisert et omfattende helseprogram. Dermed ser det ut til at deltakende lederskap, ledernes involvering, organisering og deltakelse, det årlige programmet, verdihjulet og en systematisk tilnærming til best mulig kommunikasjon om helsemessige fordeler ved fysisk aktivitet bekrefter teorien om viktige faktorer i utviklingen en en helsekultur (Golaszewski et al., 2008; Hoebbel et al., 2012; Lin \& Lin, 2014) og en sunn prestasjonskultur.

Deltakelse, engasjement og partnerskap (Cornwell, Howard-Grenville \& Hampel, 2018) med treningssenteret SATS er sannsynligvis, som teorien også antyder, en viktig suksessfaktor. Men, som både teorien og spesielt Findus-casen demonstrerer, er det felles aktiviteter som er mest verdiskapende. Ansatte som går på treningssentre på individuell basis, støttet av arbeidsgiver, vil ikke hjelpe til med å forme en helsekultur, forbedre moroa på jobben, sosialisering, relasjoner eller styrke følelsen av fellesskap. Å legge til rette for og fremme effektive helseprogrammer og felles aktiviteter med deltakende ledere som jobber på den måten Findus praktiserer, er et viktig funn som er nytt i litteraturen. En slik praksis vil sannsynligvis være en smart HR-strategi (Sullivan, 2005).

Ifølge Golaszewski et al. (2008) utgjør individuelle faktorer ansattes helsekunnskap, holdninger, ferdigheter og verdier som kan ha 
innvirkning på bedriftens helsekultur. Sett ut i fra forskningsspørsmål 3, kan det slås fast at bedriftene ikke hadde en egen helseportal tilsvarende Aker-casen nevnt tidligere (Bjerke \& Elvekrok, 2020), som kan fremme helseverdier og styrke ansattes helsekunnskap og holdninger. I figur 2 er et slikt system organisert under støttende helsemiljø. Golaszewski et al. (2008) anbefaler helseteknologi som muliggjør systematisk analyse av effekten av fysisk aktivitet på jobben. Med helseteknologi skal det være mulig å koble ansattes data om mental og fysisk helse, moro på jobben, trivsel, motivasjon, engasjement og organisasjonskultur til for eksempel sykefravær og relaterte kostnader. For eksempel kan informasjon om seminarer med helsetemaer som ligner på det Findus har implementert, knyttes til tekster om effekter av en sunn livsstil, kosthold og fysiske øvelser. En portal kan også inneholde forslag til treningsprogrammer og diett som er et eksempel på kommunikasjonen av programmer og aktiviteter (Brynjolfsson et al., 2002). Siden det er en sammenheng mellom diett og helse (Anderson et al., 2009), kan bedriftene i samarbeid med kantinene tilby mobilapper som kan gi informasjon om for eksempel næringsholdet i maten, slik Price et al. (2017) anbefaler. Alle informantene virket interesserte i å bruke en form for målesystem som viser investeringsnivå og effekter, siden selskapene har investert betydelig summer i støttende struktur (Golaszewski, Allen \& Edington, 2008).

Kommunikasjonsfunksjonen bør prioriteres, da det er utfordrende å motivere og overbevise flertallet av de ansatte om helsemessige fordeler ved fysiske øvelser. Derfor bør den primære målgruppen for arbeidsgivere være de som ikke er eller er lite fysisk aktive, en utfordring som ikke har blitt vist til i eksisterende teori.

\section{Konklusjon}

Hovedformålet med dette kapitlet er å oppmuntre bedrifter og organisasjoner til å investere i de ansattes velvære gjennom tilrettelegging for felles fysisk aktivitet slik at noen fordeler for organisasjonen oppnås. Forskningen som er vist til i dette kapitlet demonstrerer i all hovedsak at promotering og tilrettelegging for helsefremmende programmer 
rettet mot ansatte bidrar positivt for deres fysiske og mentale helse. Gitt de teoretiske sammenhengene mellom en sunn prestasjonskultur og de individuelle HR-driverne, så er det et potensial for at forbedret helsetilstand blant mange ansatte, drevet frem gjennom morsomme fellesaktiviteter, kan gi positive ringvirkninger. En sunn prestasjonskultur som er utviklet med utgangspunkt i en helsestrategi, implementering av programmer/tiltak og bruk av helseteknologi kan påvirke sykefraværet, de individuelle HR-driverne og resultatene (se figur 3). Utgangspunktet bør være at tilrettelegging for felles fysiske aktiviteter, seminarer om helserelaterte temaer og en egen helseportal med relevante funksjoner er forankret i en HR-strategi. Det er trolig at funksjoner som påmelding, registrering av trening, innhold (helseinformasjon som puls og blodtrykk), treningsprogrammer, kosthold og evalueringsmuligheter er viktige. Implementeringen av en helsestrategi (under helseledelse) kan i store selskaper styres av et helseteam som ligger under HR-avdelingen (se figur 3). Teamet kan bestå av en coach/trener, ernæringsekspert og fysioterapeut/massør. Helsetemaet kan oppmuntre og motivere ansatte til for eksempel helsefremmende møtevirksomhet som «gående møter» eller «joggemøter». Ifølge Ledernytt (2018) bruker norske ledere mellom 70-80 \% av arbeidstiden på møter, og medarbeidere nærmere 30-50 \%. Kombinasjonen av møter og fysisk aktivitet er helsefremmende og tidseffektiv. Derfor kan både helsefremmende møtevirksomhet og energipauser representere smarte, helsefremmende tiltak som kan fremme en sunn prestasjonskultur.

Hovedbudskapet i Folkehelseloven og HelseOmsorg21 er at vi skal tenke helse og forebyggende tiltak i alt vi gjør. Arbeidsgivere kan sette i verk helsefremmende tiltak, og motvirke den negative effekten av flere av de levetidsreduserende faktorene. Det kan nevnes tiltak som felles fysisk aktivitet, sosial interaksjon, hjelp til røykeslutt, influensavaksine, vektkontroll og blodtrykkssjekk. Hvis HMS-direktiver krever et opplegg for helsesikkerhet (f.eks. kostholdsikkerhet med informasjonskrav om ernæringsinnhold, mental helsesikkerhet, fysisk helsesikkerhet), med krav om tilrettelegging for fysisk aktivitet på arbeidsplassen, kan den kollektive innsatsen bidra til et helseløft blant den sysselsatte delen av befolkningen og således til folkehelsen. 


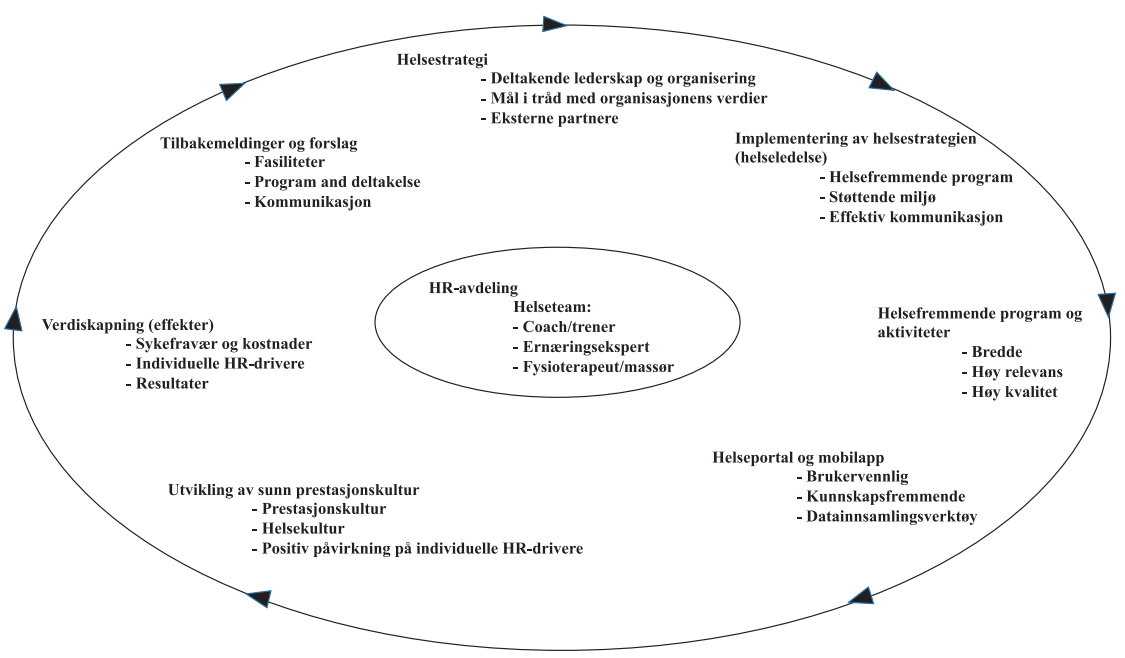

Figur 3 Implementering av sunn prestasjonskultur.

\section{Referanser}

Amlani, N. M. \& Munir, F. (2014). Does physical activity have an impact on sickness absence? A review. Sports Medicine, 44(7), 887-907. https://doi.org/10.1007/ S40279-014-0171-O

Andersen, U. \& Nossen, J. P. (2018, 24. august). Hva koster sykefraværet for bedriftene? MEMU - mennesker og muligheter. Hentet fra https://memu.no/ artikler/hva-koster-sykefravaeret-for-bedriftene/

Anderson, L. M., Quinn, T. A., Glanz, K., Ramirez, G., Kahwati, L. C., Johnson, D. B. \& Katz, D. L. (2009). The effectiveness of worksite nutrition and physical activity interventions for controlling employee overweight and obesity: A systematic review. American Journal of Preventive Medicine, 37(4), 340-357. https://doi.org/ 10.1016/j.amepre.2009.07.003

Arbeids- og inkluderingsdepartementet. (2009). Mandat for utvalg som skal vurdere øt migrasjon og internasjonal mobilitet - konsekvenser for velferdsmodellen [Artikkel]. Hentet 4. mai 2020 fra https://www.regjeringen.no/no/dep/bld/org/ styrer-rad-og-utvalg/eldre-innstillinger/vmu/mandat/id560655/

Baicker, K., Cutler, D. \& Song, Z. (2010). Workplace wellness programs can generate savings. Journal of Health Affairs, 29(2), 304-311. https://doi.org/10.1377/ hlthaff.2009.0626

Bakker, A. B. \& Demerouti, E. (2008). Towards a model of work engagement. Career development international, 13(3), 209-223. https://doi.org/10.1108/13620430810870476 
Bass, B. M., \& Avolio, B. J. (1993). Transformational leadership and organizational culture. Public administration quarterly, 17(1), 112-121. Hentet fra https://www. jstor.org/stable/40862298

Baxter, P. \& Jack, S. (2008). Qualitative case study methodology: study design and implementation for novice researchers. The Qualitative Report, 13(4), 544-559. Hentet fra https://nsuworks.nova.edu/tqr/vol13/iss4/2/

Berry, L. L., Mirabito, A. M. \& Baun, W. B. (2011). What's the hard return on employee wellness programs? Harvard Business Review, 89(3), 20-21. Hentet fra https://hbr.org/2010/12/whats-the-hard-return-on-employee-wellness-programs

Bjerke, R. (2016). Eventledelse og sponsing. Helse i hver krone. Bergen: Fagbokforlaget.

Bjerke, R. \& Elvekrok, I. (2020, 9. mars). Sponsorship-based health care programs and their impact on employees' motivation for physical activity. European Sport Management Quarterly, 1-24. https://doi.org/10.1080/16184742.2020.1735471

Bjerke, R. \& Ind, N. (2007). Organisasjonsdrevet merkebygging. Oslo: Cappelen Damm Akademisk.

Bjerke, R. \& Kirkesaether, E. (2020). How should sponsorship activation work? A sports event- and athlete-based brand building framework (SEA-BB) capturing an internal and external route. Event Management, 24(2/3), 2-3. https://doi.org/ 10.3727/152599519X15506259856002

Bono, J. E., Glomb, T. M., Shen, W., Kim, E. \& Koch, A. J. (2013). Building positive resources: Effects of positive events and positive reflection on work stress and health. Academy of Management Journal, 56(6), 1601-1627. https://doi.org/10.5465/ amj.2011.0272

Bordvik, M. \& Hafstad, A. (2019). Fedme koster Norge 68 milliarder kroner årlig. Dagens Medisin. Hentet 29. oktober 2020 fra https://www.dagensmedisin.no/ artikler/2019/05/o7/fedme-koster-norge-68-milliarder-kroner-arlig/

Braun, V., Clarke, V. \& Weate, P. (2016). Using thematic analysis in sport and exercise research. I B. Smith \& A. Sparkes (Red.), Routledge handbook of qualitative research methods in sport and exercise (s. 191-205). London: Routledge.

Brynjolfsson, E., Hitt, L. M. \& Yang, S. (2002). Intangible assets: Computers and organizational capital. Brookings papers on economic activity, 2002(1), 137-181. Hentet fra https://www.brookings.edu/wp-content/uploads/2002/01/2002a_bpea_ brynjolfsson.pdf

Conn, V. S., Hafdahl, A. R., Cooper, P. S., Brown, L. M. \& Lusk, S. L. (2009). Meta-analysis of workplace physical activity interventions. American journal of preventive medicine, 37(4), 330-339. https://doi.org/10.1016/j.amepre.2009.06.008

Cornwell, T. B., Howard-Grenville, J. \& Hampel, C. E. (2018). The company you keep: How an organization's horizontal partnerships affect employee organizational identification. Academy of Management Review, 43(4), 772-791. https://doi.org/10.5465/amr.2016.0209 
Crawford, E. R., LePine, J. A. \& Rich, B. L. (2010). Linking job demands and resources to employee engagement and burnout: a theoretical extension and meta-analytic test. Journal of applied psychology, 95(5), 834-848. https://doi.org/ 10.1037/aoo19364

Crespo, N. C., Sallis, J. F., Conway, T. L., Saelens, B. E. \& Frank, L. D. (2011). Worksite physical activity policies and environments in relation to employee physical activity. American Journal of Health Promotion, 25(4), 264-271. https://doi.org/ 10.4278/ajhp.081112-QUAN-280

Creswell, J. W., Clark, V. L. P., Gutmann, M. L. \& Hanson, W. E. (2003). Advanced Mixed Methods Research Designs. I A. Tashakkori \& C. Teddlie (Red.), Handbook on mixed methods in the behavioral and social sciences: Advanced mixed methods research designs (s. 209-240). Thousand Oaks, CA: Sage.

Creswell, J. W. \& Creswell, J. D. (2017). Research Design: Qualitative, Quantitative, and Mixed Methods Approaches. Thousand Oaks, CA: Sage.

de Chernatony, L. \& Cottam, S. (2006). Internal brand factors driving successful financial services brands. European Journal of Marketing, 4o(5/6), 611-633. https://doi.org/10.1108/03090560610657868

de Waal, A. A. (2007). Successful performance management? Apply the strategic performance management development cycle! Measuring Business Excellence, 11(2), 4-11. https://doi.org/10.1108/13683040710752698

Denison, D. R. (1990). Corporate culture, and organizational effectiveness. New York: John Wiley.

Denison, D. R. (2000). Organizational culture: Can it be a key lever for driving organizational change? I S. Cooper \& C. Cartwright (Red.), The handbook of organizational culture. London: John Wiley \& Sons.

Denison, D. R. (2001). Bringing corporate culture to the bottom line. Organizational Dynamics,13(2), 5-23. https://doi.org/10.1016/0090-2616(84)90015-9

Denison, D. R. \& A. Mishra. (1995). Toward a theory of organizational culture and effectiveness. Organization Science, 6(2), 204-223. https://doi.org/10.1287/orsc. 6.2.204

Dinbedrift.no (Redaksjonen). (2018, 21. august). Korttidssykefravær kostet næringslivet 36 milliarder i 2017. dinbedrift.no. Hentet 4. mai 2020 fra https://www.dinbedrift.no/ 2713-2/

Downward, P. \& Rasciute, S. (2011). Does sport make you happy? An analysis of the well-being derived from sports participation. International Review of Applied Economics, 25(3), 331-348. https://doi.org/10.1080/02692171.2010.511168

Farrelly, P. (2013). Choosing the right method for a qualitative study. British Journal of School Nursing, 8(2), 93-95. https://doi.org/10.12968/bjsn.2013.8.2.93

Findus. (2020). Våre medarbeidere er vår fremste styrke. Hentet 12. mai 2020 fra https://www.findus.no/brekraft/hvordan-gjor-vi-en-forskjell/vare-medarbeidere 
Folkehelseinstituttet. (2018a). Helsetilstanden i Norge 2018. Folkehelserapporten kortversjon. Hentet 4. mai 2020 fra https://www.fhi.no/publ/2018/fhr-2018/

Folkehelseinstituttet. (2018b). Ti store helseutfordringer i Norge [Notat]. Hentet 5. mai 2020 fra https://www.fhi.no/globalassets/dokumenterfiler/rapporter/2019/tistore-folkehelseutfordringer-notat-2019.pdf

Ford, M. T., Cerasoli, C. P., Higgins, J. A. \& Decesare, A. L. (2011). Relationships between psychological, physical, and behavioural health and work performance: A review and meta-analysis. Work \& Stress, 25(3), 185-204. https://doi.org/10.1080 /02678373.2011.609035

Giddens, L., Leidner, D. \& Gonzalez, E. (2017). The role of Fitbits in corporate wellness programs: Does step count matter? Proceedings of the 5oth Hawaii international conference on system sciences, 2017. Hentet fra http://hdl.handle. net $/ 10125 / 41596$

Gjensidige. (u.å.). Om oss [Hjemmeside]. Hentet 12. mai 2020 fra https://www. gjensidige.no/konsern/

Glaser, B. G. \& Strauss, A. L. (2017). Discovery of grounded theory: Strategies for qualitative research. London: Routledge.

Goetzel, R. Z., Henke, R. M., Tabrizi, M., Pelletier, K. R., Loeppke, R., Ballard, D. W. \& Kelly, R. K. (2014). Do workplace health promotion (wellness) programs work? Journal of Occupational Environmental Medicine, 56(9), 927-934. https://doi. org/10.1097/JOM.ooooooooooooo276

Golafshani, N. (2003). Understanding reliability and validity in qualitative research. The Qualitative Report, 8(4), 597-606. Hentet fra https://nsuworks.nova.edu/tqr/ vol8/iss4/6/

Golaszewski, T., Allen, J. \& Edington, D. (2008). Working together to create supportive environments in worksite health promotion. American Journal of Health Promotion, 22(4), 1-12. https://doi.org/10.4278/0890-1171-22.5.TAHP-1

Golaszewski, T., Hoebbel, C., Crossley, J., Foley, G. \& Dorn, J. (2008). The reliability and validity of an organizational health culture audit. American Journal of Health Studies, 23(3), 116-123. Hentet fra http://www.va-ajhs.com/23-3/index.aspx

Grant, A. M. \& Ashford, S. J. (2008). The dynamics of proactivity at work. Research in organizational behavior, 28, 3-34. https://doi.org/10.1016/j.riob.2008.04.002

Helse- og omsorgsdepartementet. (2014). HelseOmsorg21: Et kunnskapssystem for bedre folkehelse [Rapport]. Hentet 4. mai 2020 fra https://www.regjeringen.no/ contentassets/8ab2fd5 $54 c_{774} 6 \mathrm{dfb}_{51} \mathrm{e}_{3} \mathrm{f}_{64} \mathrm{~cd} 4 \mathrm{~d}_{7}$ 1aa/helseomsorg21_strategi_web. pdf?id $=2266705$

Helse- og omsorgsdepartementet. (2019). Folkehelseloven [Artikkel]. Hentet 4. mai 2020 fra https://www.regjeringen.no/no/tema/helse-og-omsorg/folkehelse/ innsikt/folkehelsearbeid/id673728/ 
Herzberg, F. (2003). One more time: How do you motivate employees? Harvard Business Review, 81(1), 87-96. Hentet fra https://hbr.org/2003/o1/one-more-timehow-do-you-motivate-employees

Hoebbel, C., Golaszewski, T., Swanson, M. \& Dorn, J. (2012). Associations between the worksite environment and perceived health culture. American Journal of Health Promotion, 26(5), 301-304. https://doi.org/10.4278/ajhp.101118-ARB-381

Holt-Lunstad, J., Smith, T. B., Baker, M., Harris, T. \& Stephenson, D. (2015). Loneliness and social isolation as risk factors for mortality: a meta-analytic review. Perspectives on psychological science, 10(2), 227-237. https://doi. org/10.1177/1745691614568352

Høydahl, U. H. (2020). Svak økning i sykefravøeret [Artikkel]. Hentet 4. mai 2020 fra https://www.ssb.no/arbeid-og-lonn/artikler-og-publikasjoner/svak-okning-isykefravaeret

Ind, N. (2007). Living the brand: How to transform every member of your organization into a brand champion. London: Kogan Page Publishers.

Ind, N. \& Bjerke, R. (2007). The concept of participatory market orientation: an organisation-wide approach to enhancing brand equity. Journal of Brand Management, 15(2), 135-146. https://doi.org/10.1057/palgrave.bm.2550122

Jones, D., Molitor, D. \& Reif, J. (2019). What do workplace wellness programs do? Evidence from the Illinois workplace wellness study. The Quarterly Journal of Economics, 134(4), 1747-1791. https://doi.org/10.1093/qje/qjzo23

Kaliprasad, M. (2006). The human factor II: Creating a high performance culture in an organization. Cost Engineering, 48(6), 27.

Kamarck, T. W., Schwartz, J. E., Shiffman, S., Muldoon, M. F., Sutton-Tyrrell, K. \& Janicki, D. L. (2005). Psychosocial stress and cardiovascular risk: What is the role of daily experience? Journal of personality, 73(6), 1749-1774. https://doi. org/10.1111/j.0022-3506.2005.00365.x

Karl, K., Peluchette, J., Hall-Indiana, L. \& Harland, L. (2005). Attitudes toward workplace fun: A three sector comparison. Journal of Leadership \& Organizational Studies, 12(2), 1-17. https://doi.org/10.1177/107179190501200201

Ledernytt. (2018). Kaster du bort tiden med møter? Lest 10. juni 2020 på https:// www.ledernytt.no/kaster-du-bort-tiden-med-møter.6134947-355436.html

Lin, Y. W. \& Lin, Y. Y. (2014). A multilevel model of organizational health culture and the effectiveness of health promotion. American Journal of Health Promotion, 29(1), 53-63. https://doi.org/10.4278/ajhp.121116-QUAN-562

Loehr, J. (2005). Become fully engaged. Leadership Excellence, 22(2), 14.

Luna-Arocas, R. \& Camps, J. (2008). A model of high performance work practices and turnover intentions. Personnel Review, 37(1), 26-46. https://doi. org/10.1108/00483480810839950 
McLeroy, K. R., Bibeau, D., Steckler, A. \& Glanz, K. (1988). An ecological perspective on health promotion programs. Health Education \& Behavior, 15 (4), 351-377. https://doi.org/10.1177/1090198188 01500401

Mellor, V. (1999). Delivering brand values through people. Strategic Communication Management, 3(2), 26-29.

Morrow, S. L. (2005). Quality and trustworthiness in qualitative research in counseling psychology. Journal of Counseling Psychology, 52(2), 250-260. https:// doi.org/10.1037/0022-0167.52.2.250

Nikpour, A. (2017). The impact of organizational culture on organizational performance: The mediating role of employee's organizational commitment. International Journal of Organizational Leadership, 6(1), 65-72. https://doi. org/10.33844/ijol.2017.60432

Page, K. M. \& Vella-Brodrick, D. A. (2009). The 'what,'why'and 'how'of employee well-being: A new model. Social indicators research, 9o(3), 441-458. https://doi. org/10.1007/s11205-008-9270-3

Parker, C. P., Baltes, B. B., Young, S. A., Huff, J. W., Altmann, R. A., Lacost, H. A. \& Roberts, J. E. (2003). Relationships between psychological climate perceptions and work outcomes: a meta-analytic review. Journal of Organizational Behavior, 24(4), 389-416. https://doi.org/10.1002/job.198

Ployhart, R. \& Moliterno, T. (2011). Emergence of the human capital resource: A multilevel model. Academy of Management Review, 36(1), 127-150. https://doi. org/10.5465/AMR.2011.55662569

Price, S., Bray, J. \& Brown, L. (2017). Enabling healthy food choices in the workplace: the canteen operators' perspective. International Journal of Workplace Health Management, 10(4), 318-334. https://doi.org/10.1108/IJWHM-12-2016-0o87

Pronk, N. P. \& Kottke, T. E. (2009). Physical activity promotion as a strategic corporate priority to improve worker health and business performance. Preventive Medicine, 49(4), 316-321. https://doi.org/10.1016/j.ypmed.2009.06.025

Proper, K. I., van den Heuvel, S. G., De Vroome, E. M., Hildebrandt, V. H. \& Van der Beek, A. J. (2006). Dose-response relation between physical activity and sick leave. British journal of sports medicine, 4o(2), 173-178. https://doi.org/10.1136/ bjsm.2005.022327

Schein, E. J. (1985). Organizational culture and leadership. San Francisco: Jossey-Bass. Shahzad, F., Iqbal, Z. \& Gulzar, M. (2013). Impact of organizational culture on employees job performance: An empirical study of software houses in Pakistan. Journal of Business Studies Quarterly, 5(2), 56.

Shenton, A. K. (2004). Strategies for ensuring trustworthiness in qualitative research projects. Education for Information, 22(2), 63-75. https://doi.org/10.3233/EFI2004-22201 
Spiggle, S. (1994). Analysis and interpretation of qualitative data in consumer research. Journal of Consumer Research, 21(3), 491-503. https://doi.org/10.1086/ 209413

Statistisk sentralbyrå. (2020a). Helseregnskap [Statistikk]. Hentet 4. mai 2020 fra https://www.ssb.no/helsesat

Statistisk sentralbyrå. (2020b). Sysselsetting, registerbasert [Statistikk]. Hentet 4. mai 2020 fra https://www.ssb.no/regsys

Sullivan, J. (2005). Rethinking strategic HR. Frederick, MD: CCH Incorporated.

Ten Brummelhuis, L. L. \& Bakker, A. B. (2012). A resource perspective on the workhome interface: The work-home resources model. American Psychologist, 67(7), 545-556. https://doi.org/10.1037/aoo27974

Tetrick, L. E. \& Quick, J. C. (2003). Prevention at work: Public health in occupational settings. i J. C. Quick \& L. E. Tetrick (Red.), Handbook of occupational health psychology (s. 3-17). Washington, DC: American Psychological Association.

Tews, M. J., Michel, J. W. \& Allen, D. G. (2014). Fun and friends: The impact of workplace fun and constituent attachment on turnover in a hospitality context. Human Relations, 67(8), 923-946. https://doi.org/10.1177/o018726713508143

Tews, M. J., Michel, J. W. \& Stafford, K. (2013). Does Fun Pay? The Impact of Workplace Fun on Employee Turnover and Performance. Cornell Hospitality Quarterly, 54(4), 370-382. https://doi.org/10.1177/1938965513505355

Yin, R. K. (2013). Case Study Research: Design and Methods. Thousand Oaks, CA: Sage.

Yin, R. K. (2017). Case study research and applications: Design and methods. Thousand Oaks, CA: Sage.

Watkins. K. E. \& Marsick, V. J. (Red.). (2003). Make learning count! Diagnosing the learning culture in organizations. Advances In Developing Human Resources, 5(2), 132-151. Hentet fra https://journals.sagepub.com/toc/adha/15/2

Wildermuth, C. \& Pauken, P. D. (2008). A perfect march: decoding employees engagement Part 1: Engaging Culture and Leaders. Industrial and commercial training, 4o(3), 122-128. https://doi.org/10.1108/00197850810868603

Wilhelmsen Group. (u.å.). Our ambition [Hjemmeside]. Hentet 23. oktober 2020 fra www.wilhelmsen.com

Wilson, A. M. (2001). Understanding organisational culture and the implications for corporate marketing. European Journal of Marketing, 35(3/4), 353-367. https://doi. org/10.1108/03090560110382066 


\section{Vedlegg}

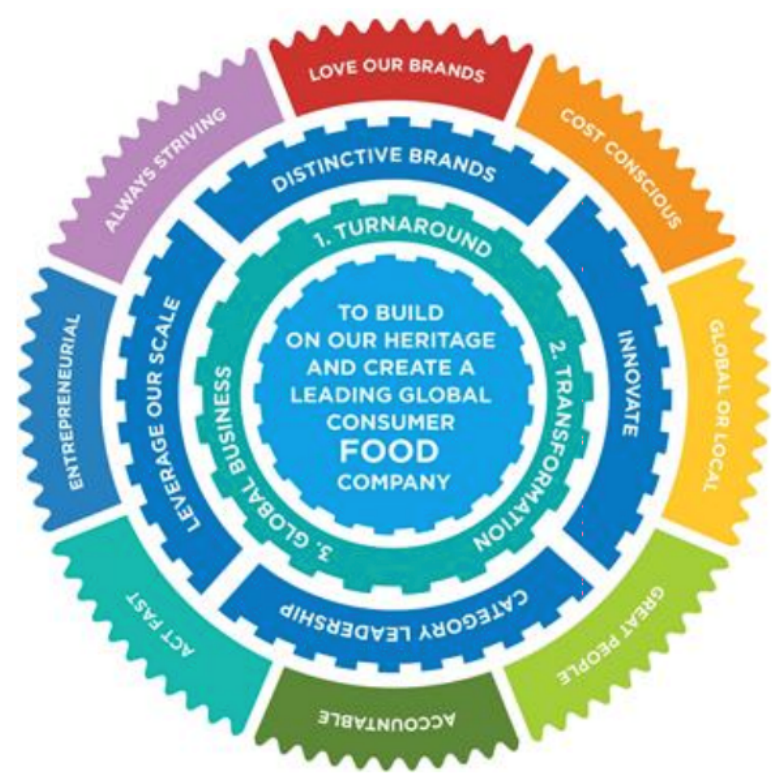

Figur 1 Findus' visjon- og verdihjul.

Tabell 1 Findus' aktivitetsplan

\begin{tabular}{|c|c|}
\hline & Physical (all year activity) \\
\hline 1 & Physical activities at yearly conferences January \\
\hline 2 & Training support 200 NOK pr month \\
\hline 3 & Plank o'clock any day a week 14:00 \\
\hline 4 & Yoga every Thursday 1515-1600 \\
\hline 5 & Energizers email \\
\hline 6 & Encourage walking lunches \& walk and talk meeting \\
\hline 7 & Walk the stairs - did you get to (I ngen forslag) - Walk from Oslo to Bergen? \\
\hline 8 & Raise the tables after the end of the day and start the next day by standing up \\
\hline 9 & Stretch exercises every week - stretch o'clock while positive gossiping \\
\hline 10 & Holmenkollen 9th May - Team running competition \\
\hline 11 & $\begin{array}{l}\text { After Work - outdoor walks up mountains (Vardåsen, Skaugumåsen, Kolsåstoppen) and } \\
\text { Semsvannet }\end{array}$ \\
\hline 12 & HIIT-training session at work every Tuesday 1545-1615 \\
\hline 13 & Bike to Work 2020 - https://www.sykletiljobben.no/ - all activities counts 60 days \\
\hline 14 & Counting steps/calories competition - sales force and Asker \\
\hline 15 & Walking meetings, standing meetings and meetings outside \\
\hline 16 & Cross-country ski trip from Sem after work \\
\hline 17 & Jogging after work - Semsvannet - 2 times before summer and 2 times after summer \\
\hline
\end{tabular}




\title{
KAPITTEL 3
}

\section{Selvledelse som mulighet i kunnskapsorganisasjoner: Trengs andre selvledelsesstrategier?}

\author{
Irmelin Drake \\ Høyskolen Kristiania
}

\begin{abstract}
Self-leadership is an increasingly current topic, not only for the sake of scholarly study and research, but not least for practical application in modern organizations. The fundamental idea of self-leadership is that employees can take on responsibility for many of the influence processes normally carried out by leaders and leadership systems. Knowledge workers is a category of employees who might be particularily in need of self-leadership, as their work is typically unstructured, cognitively taxing, and requires the right kind of mix between alone time and extensive collaboration. How to prioritize the right types of tasks, make sure to involve the right people at the right time and protect oneself from collaboration overload, generosity burnout or other types of overwork, are examples of dilemmas facing knowledge workers in their everyday working lives. Research and theoretical contributions addressing the particular concerns and needs related to knowledge workers' self-leadership, however, are limited. In this chapter, we discuss some of the most pressing issues in relation to self-leadership by knowledge workers and present several strategies that may assist and equip them with suitable self-leadership skills and capabilities. One of the main takeouts from this review is that behavioral and structural strategies should be prioritized over cognitive ones. Moreover, senior and experienced workers should make more use of the autonomy available to them by making sure they work in a sustainable manner, as well as role-modeling such behaviors and serving as coaches and mentors for more inexperienced workers.
\end{abstract}

Keywords: self-leadership, self-influence, knowledge workers, collaborative overload, holistic perspective, sustainable self-leadership strategies

Sitering av denne artikkelen: Drake, I. (2020). Selvledelse som mulighet i kunnskapsorganisasjoner: Trengs andre selvledelsesstrategier? I J. Bastesen, B. K. Lange, H. E. Næss \& A. N. Thon (Red.), Ledelse av mennesker $i$ det nye arbeidslivet (Kap. 3, s. 87-109). Oslo: Cappelen Damm Akademisk. https://doi. org/10.23865/noasp.118.ch3

Lisens: CC-BY 4.0. 


\section{Introduksjon}

Selvledelse er en aktuell ledelsesform som har potensial til å være spesielt egnet overfor autonome og høyt utdannete kunnskapsmedarbeidere som konsulenter, it-medarbeidere, profesjonsutøvere og andre typer spesialister (Amundsen \& Martinsen, 2015; Manz, 2015; Sandvik, Selart, Schei \& Martinsen, 2019). Den grunnleggende ideen i selvledelse er at medarbeidere selv kan håndtere mange av de påvirkningsprosesser som vanligvis utøves av ledere og ledelsessystemer (Lovelace, Manz, \& Alves, 2007; Sims \& Lorenzi, 1992, s. 180). Mer spesifikt kan selvledelse defineres som en påvirkningsprosess som gjør folk i stand til å styre og motivere seg selv i retning av (sine) mål og ambisjoner (Manz, 1986; Neck \& Houghton, 2006, s. 271). En skandinavisk orientert definisjon har en mer sosial tilnærming og definerer selvledelse som «den etiske bevisste innflytelsen hver enkelt utøver på sine tanker, følelser og atferd for å styrke seg selv og sin samhandling med andre» (Amundsen, 2019, s. 189). Casestudier av suksessfulle organisasjoner som opererer på bakgrunn av selvledelsesprinsipper har vist at de har fornøyde og langsiktige kunder og medarbeidere, lav turnover, lite sykefravær, høye økonomiske resultater og klarer seg bedre gjennom kriser og nedgangstider enn andre sammenlignbare virksomheter med mer tradisjonelle ledelsesstrukturer (Laloux, 2014).

Hvorvidt selvledelse egner seg overfor alle typer medarbeidere, og eventuelt på hvilke premisser selvledelse bør integreres - som for eksempel i tilfellet med kunnskapsarbeidere og konsulenter, er et åpent spørsmål. Kunnskapsarbeid bygger i stor grad på den intellektuelle kapitalen til medarbeidere (Pearce \& Manz, 2005), og det er et voksende segment av arbeidsstokken som kan karakteriseres som kunnskapsmedarbeidere (Parker, Wall \& Cordery, 2001). Selv om selvledelse har vært utbredt siden 1980-tallet, er empirisk forskning på/av selvledelse begrenset (Stewart, Courtright \& Manz, 2019). Når det gjelder forskning på selvledelse blant kunnskapsmedarbeidere generelt og i konsulentbransjen spesielt, er det kun gjort noen få empiriske studier (Amundsen \& Martinsen, 2015; Bäcklander, 2019; Empson \& Langley, 2015; Sandvik et al., 2019). Det er derfor uklart hvilke selvledelsesstrategier som egner seg overfor kunnskapsmedarbeidere spesielt, og eventuelt hvilke forhold man bør være 
oppmerksom på dersom man ønsker å iverksette selvledelsesutvikling i kunnskapsorganisasjoner (Sidwell \& Perry, 2019). Dette kapittelet har som formål å rette søkelyset mot disse spørsmålene.

Selvledelse kan på mange måter ses på som et frigjøringsprosjekt (Pearce \& Manz, 2005). Fra et individperspektiv innebærer det en innstilling om å se på seg selv og sine kollegaer som aktører som kan ta ansvar både for egen tolkning av situasjoner samt hvordan man velger å agere (eller ikke). Fra et slikt perspektiv blir ikke ansvar en byrde, men en frigjøringsmulighet. Som Erhard og Jensen (2013, s. 7) skriver:

To take the stand that you are cause in the matter contrasts with it being your fault, or that you failed, or that you are to blame, or even that you dit it. It is not true that you are the cause of everything in your life. That you are the cause of everything in your life is a place to stand from which to view and deal with life - a place that exists solely as a matter of your choice. The stand that one is cause in the matter is a declaration, not an assertion of fact. It simply says: «You can count on me (and, I can count on me) to look at and deal with life from the perspective of my being cause in the matter.»

Selvledelse handler således om å anerkjenne at man har muligheter for påvirkning i alle sammenhenger, mer spesifikt knyttet til hvordan man tenker om situasjoner, hvordan man motiverer seg selv eller hvordan man handler for å styre egen atferd i mest mulig konstruktiv retning (Neck \& Houghton, 2006).

Samtidig kan vi se for oss flere dilemmaer når vi undersøker selvledelsesstrategiene i lys av kunnskapsmedarbeidere. For eksempel kan man ikke se bort ifra at kunnskapsarbeid i seg selv er så krevende mentalt sett (van Knippenberg, Dahlander, Haas \& George, 2015) at flere av de aktuelle kognitive strategiene vil kunne påføre medarbeidere mer, og ikke mindre, belastning (Bäcklander, 2019). En annen utfordring er at flere av selvledelsesstrategiene har som formål å øke den indre motivasjonen knyttet til kjedelige og/eller vanskelige arbeidsoppgaver (Manz, 2015), mens dette typisk ikke er noe «problem» for kunnskapsmedarbeidere. Snarere kan problemet være at man er «overmotivert», og derfor ute av stand til å sette nødvendig grenser for hvor mye man jobber og hva man sier ja eller nei til (Ipsen \& Jensen, 2010; Joo \& Lim, 2009; Palm, 2008). Da 
kreves verktøy eller strategier som hjelper den enkelte til å disponere rett mengde ressurser til rett tid, i tillegg til å sørge for at man får prioritert tilstrekkelig restitusjon og hvile, snarere enn verktøy som øker motivasjonen og arbeidslysten. Faren for å selvlede seg til manglende grensesetting, overarbeid og kognitivt stress kan være nærliggende når det gjelder kunnskapsarbeidere og konsulenter (Lupu \& Empson, 2015; Bäcklander, 2019).

I svakt strukturerte arbeidssituasjoner, som typisk preger kunnskapsarbeid, må medarbeiderne selv i stor grad strukturere, kommunisere om og koordinere eget arbeid i samspill med andre (Bäcklander, 2019; Wadel, 2011). Fenomenet collaborative overload (Cross, Rebele \& Grant, 2016) representerer en klassisk utfordring i denne sammenhengen. Det beskriver en scenario der det strømmer på med oppgaver fra andre som ønsker eller trenger ens input, samarbeid, eller arbeidskapasitet for å løse sine arbeidsoppgaver eller nå egne mål. Forskning fra over 300 organisasjoner, viste at 20 til $35 \%$ av det verdiskapende samarbeidet kom fra kun 3 til 5 \% av medarbeiderne (Cross, Rebele \& Grant, 2016). Samtidig tilbringer mange medarbeidere mer enn $80 \%$ av tiden i møter eller i samarbeidende oppgaver og prosesser. Evnen til å balansere eksterne behov og interesser opp mot personlige ressurser og kapabiliteter, for derved å ta stilling til hvordan man skal respondere på henvendelser fra andre, blir derfor en sentral selvledelseskapasitet. Cross et al. (2016) rapporterer at de medarbeiderne som er mest etterspurt som kilder til informasjon for andre og som samarbeidspartnere, skårer lavest hva angår engasjement og karrieretilfredshet. Det tyder på at mange mangler nødvendige selvledelseskapasiteter. Til tross for at selvledelse kan bidra med nyttige og helt nødvendige hjelpemidler når det gjelder håndtering av slike samarbeidsforespørsler, krever selvledelse i seg selv kognitive ressurser som ikke alltid er fornybare (Baumeister, Heatherton \& Tice, 1994; Bäcklander, 2019). Dermed kan det virke umulig å prioritere utvikling av selvledelsesferdigheter på kort sikt, noe som kan skape mer graverende negative konsekvenser på lang sikt.

Økt bruk av ulike kommunikasjonsplattformer og digitale samarbeidspraksiser kan også skape særlige utfordringer for kunnskapsmedarbeidere. Lansmann \& Klein (2018) beskriver hvordan ulike software-plattformer 
skaper negative (og ofte utilsiktede) effekter for dem som må respondere på andres kommunikasjonsbehov. Generosity burnout (Grant \& Rebele, 2017) er et fenomen som kan oppstå når individer unnlater å beskytte sin egen tid og energi i tilstrekkelig grad, mens de samtidig gir støtte og oppmerksomhet til andre. Å si nei til forespørsler på en ryddig måte, er derfor en kapasitet som kan være helt nødvendig i selvledelsesverktøyskassen til kunnskapsmedarbeidere. Kanskje gjelder det særlig yngre kunnskapsmedarbeidere som ikke har den samme autoriteten og gjennomslagskraften som mer erfarne medarbeidere. Forskning tyder også på at det kan være særlig nyttig for de kvinner (og menn) som tar på seg en uforholdsmessig stor andel av energikrevende og overbelastende støtte- og hjelpefunksjoner i organisasjoner (Cross et al., 2016).

Gitt at selvledelse kan vise seg å være en helt sentral kapasitet for at kunnskapsmedarbeidere skal evne å håndtere egen arbeidshverdag og samspillet med andre på en bærekraftig måte, vil vi i dette kapittelet undersøke hva litteraturen kan bidra med for å svare på spørsmålet om hva slags selvledelsesstrategier som kan være særlig egnet overfor kunnskapsmedarbeidere. Dette vil kunne representere nyttig kunnskap både for enkeltpersoner som selv jobber med kunnskapsarbeid og for HR-ansvarlige, organisasjons- og ledelseskonsulenter og ledere som ønsker å oppdatere seg rundt aktuelle verktøy og strategier for selvpåvirkning, og hvordan man kan gå frem for å integrere slike i praksis. Kapittelet vil dermed kunne bidra til litteratur om selvledelse generelt, selvledelsesstrategier overfor kunnskapsmedarbeidere spesielt, og tilrettelegging av selvledelse i kunnskapsorganisasjoner.

Kapittelet er strukturert som følger. Først gir vi et overordnet innblikk i den normative selvledelsesteorien, som på mange måter utgjør det faglige utgangspunktet for forskning og teori om selvledelse i organisasjoner. Videre tar vi for oss noen av de mekanismer individer kan aktivere for å konstruktivt påvirke seg selv og sin samhandling med andre, spesielt sett i lys av at man som kunnskapsmedarbeidere typisk arbeider i ustrukturerte omgivelser med stort press på krevende tenkearbeid (Karp, 2016; Schwartz \& McCarthy, 2007). Videre tar vi for oss forskning som spesielt har undersøkt selvledelse som problem i kunnskapsorganisasjoner. Avslutningsvis oppsummerer vi våre funn i form av implikasjoner for selvledelsesutvikling i kunnskapsorganisasjoner. 


\section{Den normative selvledelsesteorien}

I USA ble selvledelse som fenomen utviklet i kjølvannet av leadership substitutes theory, som viste at ulike faktorer kunne erstatte behovet for ledelse (Kerr \& Jermier, 1978). Selvledelsesteorien utviklet seg videre fra disse perspektivene på 1980-tallet, først omtalt som self-management (Manz \& Sims, 1980), og deretter som self-leadership (Manz, 1983, 1986). Sistnevnte defineres typisk som «the set of strategies a person uses to influence him- or herself» (Sims \& Lorenzi, 1992, s. 180).

Som nevnt er teorien først og fremst normativ eller preskriptiv, det vil si at den beskriver hva som bør gjøres for å utøve selvledelse snarere enn å forklare eller beskrive hvordan selvledelse fungerer i praksis. Den har med andre ord som formål å si noe om hvordan selvpåvirkning bør foregå fra et ideelt perspektiv (Neck \& Houghton, 2006, s. 274). Manz (1986, s. 589) var særlig opptatt av hva som kan gjøres når motivasjon til å gjøre kjedelige eller vanskelige oppgaver er fraværende. Man tenker da først og fremst på unntakssituasjoner, der det trengs ekstra tiltak for å få gjennomført det man har satt seg fore. Etter hvert har selvledelse blitt definert både bredere og mer generelt. Neck \& Houghton (2006, s. 274) definerer selvledelse slik: «a broad set of strategies that may be useful in leading to greater personal effectiveness».

Strategiene som utgjør den normative teorien er inndelt i tre overordnete kategorier: atferdsrelaterte strategier, naturlige belønningsmekanismer og kognitive strategier. Når det gjelder atferdsmessige strategier, handler de om hvordan egen atferd kan innrettes for å sikre måloppnåelse eller at man gjør det man helst bør gjøre. De vanligste atferdsrelaterte strategiene som nevnes i litteraturen er selvobservasjon, selvmålsetting, selvkorreksjon, selvfeedback, selvpåminnelser og trening (Neck \& Houghton, 2006). Manz (2015) omtaler for øvig selvobservasjon som selve livsnerven i selvledelse. Gjennom å observere eller få innblikk i egen atferd, kan man identifisere uproduktiv eller lite egnet atferd og utforme tiltak for å imøtegå denne. Man kan også lete etter særlige styrker eller det som er lett for en å gjøre, og lage en plan for å gjøre mer av det. I praksis kan selvobservasjon innebære daglig journalføring, notering av sentrale hendelser, kartlegging av styrker og svakheter og/eller tilbakemeldinger fra kolleger, ledere og andre interessenter (Brun \& Ejsing, 2010; Manz, 2015). 
Naturlige belønningsmekanismer bygger i stor grad på selvbestemmelsesteorien til Deci og Ryan (2008), og handler om å tilrettelegge for naturlig indre motivasjon som særlig knyttes til tre forhold: i) autonomi, ii) det å føle seg kompetent/mestre noe og iii) relasjonell tilhørighet. Anvendt på selvledelse, er ideen å bygge slike elementer inn i en gitt aktivitet (som ikke har dette naturlig i seg), slik at den blir mer interessant og spennende å holde på med. Naturlig belønning kan også skapes som et resultat av styrt persepsjon, for eksempel ved å flytte oppmerksomheten over på de elementene ved en oppgave som føles motiverende, meningsfylt og givende.

Den tredje kategorien av selvledelsesstrategier er kognitive strategier. De går ut på å arbeide med egne tankemønstre for å bidra til mer konstruktiv tenkning. De tre strategiene som vanligvis nevnes i denne kategorien er i) identifisering og bearbeiding av dysfunksjonelle forestillinger og antagelser knyttet til egen prestasjonsevne, ii) positivt selvsnakk og iii) mental visualisering. Den første strategien er nært knyttet opp til at negative og dysfunksjonelle tankeprosesser kan forårsake nedstemthet som et problem i seg selv, i tillegg til ineffektivitet (Houghton, Wu, Goodwin \& Manz, 2012). Det vil derfor være dobbelt nyttig å bearbeide og erstatte negative tanker og usikkerhet knyttet til fremtidige utfordringer med mer positive tankemønstre. Det kan for å eksempel gjøres ved å dreie den indre monologen i retning hva som er mulig og ønskelig, eller ved å utvikle positive bilder av fremtidige prestasjoner gjennom visualiseringsteknikker. Forskning har vist at dette vil påvirke de etterfølgende prestasjoner (Driskell, Copper \& Moran, 1994). Det kan også forklare effekter som mindre stress og angst i tilknytning til jobben (Lovelace et al., 2007; Unsworth \& Mason, 2012).

Review-artikler om ulike selvledelsesstrategier som bygger på dette teoretiske fundamentet kan finnes i Manz (1986), Neck og Houghton (2006), Stewart, Courtright og Manz (2011) og Stewart et al. (2019). Vi skal nå se nærmere på noen bidrag fra forskningsfeltet som løfter frem faktorer og strategier vi oppfatter som særlig relevante for kunnskapsmedarbeidere.

\section{Selvledelse med hele mennesket i fokus}

I 2007 publiserte Schwartz og McCarthy artikkelen «Manage your energy, not your time» i Harvard Business Review, og bidro dermed til å 
legitimere erkjennelsen av at ledere og medarbeidere er hele mennesker som påvirkes av både egen fysiologi og andre forhold som regulerer deres energi og arbeidsevne. De gjennomførte diverse intervensjoner blant ledere i banknæringen, som gikk ut på å påvirke følgende fire faktorer: fysiologi, emosjoner, kognisjon og spiritualitet. Selv om forskningen ble utført på ledere, er den både gjenkjennbar og aktuell for kunnskapsmedarbeidere som preges av mange av de samme kontekstuelle rammebetingelsene som ledere: høyt arbeidspress, store krav til både mentalt fokus og beslutningsevner, ustrukturert arbeidssituasjon, osv.

To av faktorene til Schwartz og McCarthy (2007), fysiologi og spiritualitet, er særlig interessante fordi de tar for seg mekanismer som tydeliggjør og utvider perspektiver fra den opprinnelige selvledelsesteorien omtalt tidligere. Spiritualitet viser til energien som kommer fra ens dypeste verdier, og som manifesterer seg i behov for mening og engasjement i arbeidssituasjonen. Forskning viser at å oppleve arbeidet som meningsfylt og som noe større enn en selv, bidrar til større jobbtilfredshet, høyere produktivitet, lavere turnover og økt lojalitet (Barsh, Cranston \& Craske, 2008, s. 38-39). Et viktig spørsmål blir da hvordan det går an å påvirke opplevelsen av mening i jobbsituasjonen. Schwartz \& McCarthy (2007) anbefaler å kartlegge ens kjerneverdier, i tillegg til å identifisere de tingene man liker å gjøre i jobbsituasjonen (det som gir flytfølelse), for så å påvirke jobbinnholdet slik at det speiler mer av det man finner verdifullt og meningsfylt. For kunnskapsmedarbeidere er disse anbefalingene sannsynligvis lettere å implementere enn for andre medarbeidere som har mer strukturert og mindre fleksibelt jobbinnhold. Det å tone ned oppgaver som oppleves som mindre meningsfylte, og fremme prosjekter som gir mening og skaper flyt i arbeidssituasjonen, er ofte en mulighet innen kunnskapsarbeid. Jobb skulpturering er et begrep som skildrer slike prosesser: kunsten å forme jobben slik at ens dypere livsinteresser og preferanser fremmes (Butler \& Waldroop, 1999). Også hva angår samarbeid, er det ofte mulig å prioritere typer av samarbeid som oppleves som mer meningsfylt. Cross et al. (2016) viser til forskning de gjennomførte i et teknologiselskap på Fortune 500-listen, som fant at selv om $60 \%$ av medarbeiderne ønsket å bruke mindre tid på å respondere på ad hoc forespørsler om samarbeid, ønsket 40 \% å bruke mer tid 
til utvikling, coaching og mentoring av andre. Dette tilsier at det føles mer meningsfylt å inngå i utviklingsprosesser sammen med andre medarbeidere, altså når samarbeidet har et sosialt formål (Baumeister, Vohs \& Tice, 2007), noe vi skal komme tilbake til senere i kapittelet.

Fysisk kapasitet handler om faktorer som søvn, kosthold, restitusjon og trening, og er sentralt fordi det er kilde til arbeidsevne, utholdenhet, mental og emosjonell kapasitet, og bidrar til opprettholdelse av viljestyrke. Hvordan skal man gå frem for å påvirke de fysiologiske mekanismene? Her påpeker Schwartz og McCarthy (2007) at det er viktig å oppdage energitap og behov for restitusjon. Man kan kartlegge sin egen energibalanse og føre journal over søvnmønstre, kosthold og treningsaktivitet. I det daglige kan man være oppmerksom på fordelene ved å ta mange pauser, sørge for et mest mulig sunt kosthold, huske å senke skuldrene eller legge inn små mindfulnessøvelser i løpet av dagen. Når det gjelder betydningen av denne kategorien selvledelsesstrategier for kunnskapsmedarbeidere, er den særlig viktig. Det å prioritere egen fysiologi er helt grunnleggende for å kunne fungere i mentalt krevende jobber over tid. Hjernen utgjør bare $2 \%$ av vår kroppsvekt, men benytter 25-30 \% av energien fra det vi spiser (Swart, 2019). Å være sulten påvirker beslutningsevnen. Et eksempel på det er en studie av 1000 dommer som viste at saker som ble prosessert rett etter lunsj hadde mer enn seks ganger så stor sannsynlighet for å ende opp med en frikjennelse som de siste sakene i løpet en sesjon (Danziger, Levav \& Avnaim-Pesso, 2011). Nyere nevrovitenskap viser for øvrig klare sammenhenger mellom hjernens mentale kapasitet og vår livsstil; det være seg i form av maten vi spiser, hvor mange timer søvn vi får, fysisk trening eller bevegelse, resitusjon, meditasjon o.l. (Swart, 2019). Som Rock og Schwartz påpekte allerede $\mathrm{i}$ 2007, i artikkelen «The Neuroscience of Leadership», er det på tide å være mer opptatt av hva hjernen trenger for å fungere på sitt beste i et kunnskapssamfunn der folk lever av å tenke og lære.

I norsk sammenheng har Karp (2016) gjort et verdifullt bidrag til selvledelseslitteraturen ved å presentere en seks-faktors selvledelsesmodell. ${ }^{1}$ 
I tillegg til tre av Schwartz og McCarthys elementer (følelser, tanker, og fysiologi), har modellen to atferdsvariabler og en viljefaktor. Atferdsvariablene speiler mye av innholdet fra selvledelsesteorien til Manz og kollegaer, men den er nyansert og utvidet gjennom et skille mellom atferd og sosial atferd. Sosial atferd, slik Karp (2016) operasjonaliserer begrepet, handler først og fremst om samarbeidsevner og hvordan man agerer i samspill med andre. Denne dimensjonen svarer opp en uttalt etterspørsel etter mer sosiale og kollektive påvirkningsmekanismer som er relevante for individers ytelse og prestasjoner i et kunnskapssamfunn som krever mer og mer samarbeid og samspill generelt (Amundsen, 2019; Wadel, 2011).

Kollegialt ansvar, støtte og sosial atferd er for øvrig et sentralt premiss for begrepet medarbeiderskap, som har hatt stor utbredelse i norsk og svensk arbeidsliv. Medarbeiderskap har blitt løftet frem som et alternativ til selvledelse, men med et mer kollektivt perspektiv (Velten, Ackerman, Hällstén \& Tengblad, 2008). Medarbeiderskap har til felles med lederskap at det handler om påvirkning, i dette tilfellet hvordan «jeg» som medarbeider forholder meg til andre, og hvordan «jeg» påvirker og blir påvirket av andre rundt meg (Velten, Ackerman, Hällstén \& Tengblad, 2008, s. 24). Her har sosial atferd ikke bare en mottakerside (hvordan du kan få nytte og glede av andres støtte og hjelp), men også en giverside. Denne handler blant annet om å stille spørsmålet: Hva slags arbeidsmiljø er jeg for deg? $\AA$ selvlede seg i retning av andres behov og interesser kan være et vesentlig poeng i kunnskapsorganisasjoner, og ikke minst i konsulentvirksomheter hvor kollegial påvirkning er en helt sentral side av kulturen (Empson \& Langley, 2015). Werr og Stjernberg (2003) viser til at selskaper som Accenture og Cap Gemini Ernst \& Young baserer seg på utstrakt grad av individuell- og gruppecoaching for at yngre og mer uerfarne medarbeidere skal få tilgang til de mer erfarne konsulentenes spesifikke erfaringer og tause kunnskap. Andre eksempler på den positive betydningen av sosial atferd er forskning som har vist at det å motta emosjonell støtte og oppmuntring fra ens kollegaer har en positiv effekt på utholdenheten til en person som selv føler seg tappet for energi (Martijn et al., 2007). Samtidig må man her være oppmerksom på faren for collaborative overload og/eller generosity burnout, som vi har beskrevet tidligere. Det å regulere 
hvor mye eller lite man skal bistå andre i deres utviklingsprosjekter eller daglige håndtering av arbeidsoppgaver, er svært viktig for å ivareta egen helse og produktivitet over tid. En relativt enkel atferdsstrategi som kan være egnet i slike sammenhenger er Eisenhowers prioriteringsmatrise (se Karp, 2016, s. 135). Den går ut på å prioritere oppgaver i form av hva som er mer eller mindre viktig, og hva som haster eller ikke haster. For mange vil en så enkel øvelse synliggjøre at det allerede er så stappfullt i kolonnen med viktige hastesaker, at de derfor oftere må si nei til andre oppgaver eller finne andre måter å få delegert bort viktige hastesaker på (se også Thompson \& Hatlevoll, 2019).

Den siste faktoren i Karps (2016) modell er vilje. Den er viktig, ikke minst i lys av forskning som tyder på at vilje, eller selvkontroll, er en begrenset ressurs (Baumeister, Bratslavsky, Muraven \& Tice, 1998; Baumeister et al., 2007; Baumeister, Tice \& Vohs, 2018; Martijn et al., 2007; Sjåstad \& Thorbjørnsen, 2018). Samtidig synes den populære oppfatningen blant folk flest å være at viljestyrke først og fremst handler om å være tilstrekkelig disiplinert. Når Karp (2016) operasjonaliserer vilje, viser han til både selvmålsetting og selvmotivasjon, altså at det handler om å vite hva man vil og hvorfor. Men det viktigste spørsmålet er kanskje om man evner å mobilisere viljestyrke når man trenger det. Viljestyrke kan benyttes for å få gjennomført ting man har forpliktet seg til eller har som mål, når man egentlig har mest lyst å la det være fordi oppgavene er vanskelige eller man er umotivert. Men studier viser altså at viljestyrke er en begrenset ressurs. Deltakere som har utført en oppgave som har krevd høy grad av selvkontroll (viljestyring), har dårligere tilgang til psykologiske ressurser i påfølgende oppgaver som også krever selvkontroll, noe som gjør at de presterer dårligere enn deltakere som ikke allerede har utført en krevende oppgave først (Baumeister et al., 2007; Martijn et al., 2007). I tillegg viser forskning at viljestyrken avhenger av tilgjengelig fysiologisk energi i form av glukose (Gailliot et al., 2007; Baumeister et al., 2018). For eksempel har det blitt gjort eksperimenter der det å drikke et glass lemonade har økt viljestyrken til deltakere etter de har utført en krevende oppgave som har tæret på selvkontrollen, men ikke når sukkeret i lemonaden ble erstattet med et kunstig søtstoff (Gailliot et al., 2007). Dette underbygger at viljestyrke avhenger av fysiologiske ressurser, og at den både må porsjoneres ut med kløkt og «fylles på» for å bli fornyet. 
Det er heldigvis andre ting enn å drikke sukkerholdig lemonade som kan hjelpe mot dette fenomenet, også kalt ego-deplesjon. Det kan for eksempel være humor og latter, positive emosjoner generelt, å få et monetært insentiv, implementeringsintensjoner (hvis X, så Y-planer) og sosiale formål som å ville hjelpe folk, å ville være en god relasjonell partner o.l. (Baumeister et al., 2007, s. 353). Denne forskningen tyder på at det ikke er tilstrekkelig å betrakte vilje, måloppnåelse og selvkontroll som spørsmål om mental innstilling, tankedisiplin eller personlighet, men at det er en del av et dynamisk system som påvirkes av både tenking, atferd, følelser, relasjoner og fysiologi (Baumeister et al., 2007).

Alle utfører selvledelse i mer eller mindre grad (Amundsen, 2019). I det følgende skal vi ta for oss et forskningsbidrag om selvledelse blant kunnskapsmedarbeidere og konsulenter i særdeleshet.

\section{Selvledelsesstrategier i kunnskapsorganisasjoner}

Bäcklander (2019) har forsket på og skrevet doktorgrad om selvledelse i tre kunnskapsorganisasjoner i Sverige og Danmark. Hun er særlig opptatt av å påpeke hindringer som kan gjøre det enkelte individ ute av stand til å utøve selvledelse, og viser også til problemet med ego-deplesjon; at man tappes for personlige ressurser som man i neste omgang trenger for å opprettholde selvledende atferd, ta kloke beslutninger eller gjøre det man har planlagt eller forpliktet seg til (Baumeister, 2002; Baumeister et al., 2007; Baumeister et al., 2018). Dette har konsekvenser for hvilke type selvledelsesteknikker man vil kunne håndtere, og hva som er realistiske ambisjoner når det gjelder utøvelse av selvledelse i et allerede krevende jobbliv. Bäcklander (2019 s. 85) skriver: «When work is already complex and cognitively taxing, relying on internal regulation strategies to control behavior is unreliable». Hun påpeker videre at selvledelse i kunnskapsorganisasjoner er særlig avhengig av selvstyring og selvregulering.

Selvstyring handler først og fremst om at medarbeidere og ledere har en klar retning og mål for arbeidet, altså at de vet hva de skal gjøre. I kunnskapsarbeid kan det være mange uklarheter med hensyn til hva man skal bruke tiden på, hvilke oppgaver som er viktigst å gjøre og i hvilken rekkefølge man bør utføre dem. Gjennom bortfall eller svekking av 
strukturelle elementer som klare jobb-beskrivelser og arbeidsprosesser, kan en slik arbeidssituasjon karakteriseres som «svak» (Mischel, 1977; Weick 1996). Det vil si at signaler og forventninger om hva som skal gjøres, når det er nok, eller hvem som er ansvarlig for hva, er fraværende eller uklare og overlates til den enkelte (Allvin, Mellner, Movitz \& Aronsson, 2013). Dette er også omtalt som underdesignet arbeid (Hatchuel, 2002) eller en svakt strukturert arbeidssituasjon (Papavassiliou \& Mentzas, 2003). Dette krever på sin side at man som medarbeider evner å jobbe intuitivt, og kan leve vel med at det ikke er noen fasit-lignende svar på hva som trengs eller ikke trengs i en gitt situasjon (Mischel, 1977), noe som kan være spesielt krevende for nykommere eller uerfarne kunnskapsmedarbeidere. Forskning på konsulenter tyder på at en av de største forskjellene på erfarne medarbeidere og nykommere, er nettopp hvordan de erfarne klarer å agere konstruktivt i uforutsigbare situasjoner (Empson \& Langley, 2015). Uten tilstrekkelig evne til å bedømme en situasjon og gjøre fornuftige valg, vil en slik ustruktur imidlertid kunne føre til dårligere ytelse (Chan, 2006). Forskning har også vist at folk med lav opplevd mestringstro fikk dårligere helse av å fungere under høyt jobbpress og høy situasjonskontroll (Lovelace et al., 2007). Med andre ord vil en persons oppfatning om egen evne til å mestre en situasjon påvirke hvor effektivt det er å gi personen mer kontroll over situasjonen. Men dette er ikke et enten-eller-scenario. Hvis vi går tilbake til de naturlige belønningsstrategiene fra den normative selvledelsesteorien, kan disse for eksempel benyttes for å bevisst øke tolkning av egen mestringskapasitet. Det kan gjøres gjennom å hente frem vikarierende erfaringer fra situasjoner hvor man har mestret noe tidligere, observere andre som har mestret noe og som man kan identifisere og sammenligne seg med, få tilbakemeldinger fra andre om hvorfor de tror du kan mestre noe, eller finne frem til tidligere beskrivelser av mestringsopplevelser, feedback eller ros fra andre som kan minne en på hva man (faktisk) har kapasitet til. Dette vil kunne øke ens mestringstro, som igjen positivt vil påvirke handlefriheten og ansvaret man kan håndtere i bestemte situasjoner uten at det fører til stress eller til at man føler seg overveldet. Forskning har for øvrig også vist at sammenhengen mellom selvledelse og tilfredshet i jobben kan være avhengig av om arbeidssituasjonen er lagt til rette for denne måten å 
arbeide på, og om medarbeiderne har nødvendig selvledelseskompetanse (Roberts \& Foti, 1998). Det tilsier også at de stukturelle rammebetingelsene må være tilrettelagt, slik at man kan ta nødvendige beslutninger og gjøre vurderinger uten å bli klandret for det i ettertid.

Den andre faktoren Bäcklander (2019) lanserer som sentral for kunnskapsmedarbeideres selvledelse, er selvregulering. Den handler mer om hvordan man sørger for å få gjort arbeidet man har ambisjon om eller er pålagt å gjøre. For eksempel kan man jobbe med sin egen disiplin, og unngå distraksjoner eller avbrytelser i arbeidet ved hjelp av viljestyrke. Eller man kan strukturere situasjonen slik at distraksjoner ikke forekommer så lett, for eksempel ved å skru av e-postprogrammet eller sitte hjemme og jobbe på viktige oppgaver som krever uforstyrret oppmerksomhet. Amundsen og Martinsen (2015) fant at selvregulering har økende betydning for gode prestasjoner jo mer man jobber, eller jo mer man er under press om å jobbe.

Sjåstad og Thorbjørnsen (2018) beskriver hvordan fenomenet dulting kan bidra til at folk gjør valg som er bedre for seg uten at man er avhengig av selvkontroll eller en (betydelig) mental innsats. Dette oppnås ved å gjøre det «riktige» alternativet mer tilgjengelig, og/eller gjøre fristelser og distraksjoner mindre tilgjengelige eller mer innsatskrevende. God selvkontroll handler mer om hva personen gjør før fristelser oppstår (Ent, Baumeister \& Tice, 2015; Hofmann, Baumeister, Förster \& Vohs, 2012). Det handler om å være klar over sine langsiktige mål og gjøremål (Thaler \& Sunstein, 2008) og ta overordnete beslutninger som slutter opp om disse. Dette vil kunne hindre behovet for å gjøre nye vurderinger hver gang en mulighet eller distraksjon oppstår, noe som krever mental kapasitet. Ved på forhånd å tenke gjennom og prøve å forutse hva slags utfordringer og distraksjoner som vil kunne oppstå, kan man planlegge hvordan man kan unngå slike, og i stedet oppsøke eller skape situasjoner som gjør det enklere å ta gode valg. På denne måten dulter man seg i retning av en positiv atferd. Ideen er altså å være «føre var» i form av å planlegge for riktig atferd, snarere enn å måtte stole på at man reagerer konstruktivt i en gitt situasjon. (Det er først når den konstruktive atferden er blitt til vane, og dermed automatisert, at man kan belage seg på sine intuitive reaksjoner og atferdsmåter.) 
Dette perspektivet bygger imidlertid på en forestilling om at ting lar seg planlegge og forutsi, mens det i dagens dynamiske arbeidshverdag kan være like viktig å være fleksibel og endringsvillig, og nettopp ikke følge planer, men være i stand til å reagere på plutselige behov og muligheter. Hvordan skal man sikre at ikke egen selvledelse hindrer en fra å være tilgjengelig og til stede for andre i aktuelle situasjoner, eller å kunne gripe eventuelle muligheter som oppstår?

I en empirisk studie som induktivt utforsket lederes selvledelsesstrategier over tid, fant Pina e Cuhna, Pacheco, Castanheira og Rego (2017) at selvledelse handlet om å balansere mellom ytterpunkter i form av fire dualiteter som dro i hver sin retning i deres hverdag: uforutsigbarhet vs. planmessighet (utfordringer og rutiner); selvutvikling vs. relasjonelt fokus (selv og andre); personlig tilfredshet vs. profesjonell tilfredshet (jobb/ $i k k e$ jobb); fysisk helse vs. mental helse (kropp og sjel). Utfordringen her ligger i at fordi dualiteter er vanskelig å balansere (altså at man får viet begge oppmerksomhet uten at det ene går på bekostning av det andre), kan man overinvestere i den ene faktoren på bekostning av den andre (Pina e Cuhna, Pacheco, Castanheira \& Rego, 2017). Selvledelseskomponenten handler dermed i stor grad om at man må være refleksiv om sine handlinger, skriver forfatterne, og spesielt være oppmerksom på risikoen for å miste balansen. Hvis kunnskapsarbeiderne ikke gjør det, kan de avspore: de kan overarbeide seg selv, miste kontakten med familielivet, eller hoppe fra utfordring til utfordring for å finne konstante former for spenning. Man kan også bevege seg i retning av sosial uansvarlighet (Manz, 2015; Pearce \& Manz, 2011), hvis man blir for rigid med tanke på å holde på egne (forhåndsbestemte) planer og rutiner på bekostning av andres behov og interesser.

Et viktig moment av særlig betydning når det gjelder selvledelse i kunnskapsorganisasjoner er det såkalte autonomiparadokset. Det innebærer at folk tilsynelatende har autonomi til å gjøre som de vil, men likevel ikke gjør det (Empson \& Langley, 2015). Som en partner i et revisjonsfirma uttalte:

I do what I want, but the things that I want are likely to help the firm because that is the way I have been trained. At one level we are completely independent, but we all march to the same tune without even thinking about it. (Empson \& Langley, 2015, s. 30) 
Det innebærer blant annet å sette jobben først, også når det går ut over egne fritidsaktiviteter. "Jobben vinner», rapporterer Thompson og Hatlevoll (2019, s. 48), og forklarer at mange ledere i deres undersøkelser blir styrt av ytre omstendigheter og oppfører seg mer som en brikke enn en aktør. I et arbeidsliv som blir stadig mer grenseutflytende med tanke på hva som er jobb og hva som hører privatlivet til, og i lys av at kunnskapsmedarbeidere ofte har svært høy indre motivasjon, er ambisiøse og utviklingsorienterte (Ipsen \& Jensen 2010), vil også fenomenet honningfellen kunne oppstå. Det innebærer at en manglende grensesetting med tanke på hvor mye arbeid som skal gjøres, og uklarheter med hensyn til hva egentlig som er god nok arbeidsinnsats, kan få konsekvenser som overarbeid, at man går på jobb selv om man er syk, konstant tenker på jobb eller til og med blir utbrent (Mazmanian, Orlikowski \& Yates, 2013; Michel, 2014; PerezZapata, Pascual, Álvarez-Hernández \& Collado, 2016). For å unngå dette, er det nødvendig at medarbeidere benytter den autonomien de har til å planlegge, tilrettelegge og gjennomføre arbeidsdager som er bærekraftige på lang sikt. Hvis mer erfarne medarbeidere går foran og viser vei, er det større sannsynlighet for at de andre følger etter (Empson \& Langley, 2015).

\section{Konklusjon: Implikasjoner for selvledelsesutvikling}

I dette avsluttende delkapittelet skal vi oppsummere hva slags retningslinjer eller anbefalinger vi kan hente ut fra den kunnskapen vi har tatt for oss, og hvordan disse kan benyttes i et eventuelt selvledelsesutviklingsprosjekt i praksis.

Selvledelse er mekanismer og strategier den enkelte kan benytte for konstruktiv selvpåvirkning. Alle driver mer eller mindre bevisst med selvledelse, men det er stor forskjell på kvaliteten av denne selvpåvirkningen (Amundsen, 2019). Individuell selvpåvirkning er særlig viktig for kunnskapsarbeidere og konsulenter fordi de selv må sørge for å styre og regulere sin atferd og tenking i forbindelse med krevende og kompliserte jobboppgaver i samspill med andre.

Forskning viser at evnen til selvledelse kan trenes opp (Furtner, Sachse \& Exenberger, 2012; Sampl, Maran \& Furtner, 2017; Unsworth \& Mason, 
2012), og bør derfor betraktes som en kompetanse eller kapabilitet (Neck \& Manz, 2010). Samtidig er det et faktum at trening og kompetanseutvikling kan innebære langvarige og tidkrevende prosesser (Sidwell \& Perry, 2019).

Det er ulike tilnærminger til hvordan utvikling av selvledelse kan foregå i organisasjoner, men få tilgjengelige «oppskrifter». Pina e Cuhna et al. (2017) forsket som nevnt over på hvordan ledere utøver selvledelse i hverdagen. Et spesielt nyttig bidrag fra denne artikkelen er at forfatterne utreder implikasjoner av funnene fra et utviklingsperspektiv. For eksempel anbefales det å utvikle systemer som kan sikre refleksjon og dialog om den vanskelige balansegangen selvledelse innebærer. Forfatterne påpeker at det å bringe dilemmaer og konfliktstoff til overflaten kan skape rom for å drøfte åpent tema som arbeidsnarkomani, ubalanse og tilstedeværelse, og slik bli en drivkraft for individuell utvikling i psykologisk trygge omgivelser (Edmondson \& Lei, 2014).

Yngre og uerfarne konsulenter vil sannsynligvis ha større utbytte av selvledelsestrening enn mer erfarne medarbeidere som allerede behersker disse teknikkene uten nødvendigvis å være klar over at det er de gjør. Personlighet vil også kunne påvirke hvor nyttig slik trening vil være for eksempel vil medarbeidere med høy grad av pålitelige, lojale og samvittighetsfulle personlighetstrekk ha mindre utbytte, fordi de allerede agerer svært likt anbefalinger fra selvledelsesstrategier (Williams, 1997). Disse vil i stedet kunne fungere som rollemodeller, coacher eller veiledere overfor kollegaer innen selvledelsesutvikling. Et annet poeng det er verdt å trekke frem, er det tidligere nevnte autonomiparadokset. Dette preger kulturen i mange kunnskapsorganisasjoner, inkludert i konsulentbransjen, der folk i liten grad benytter friheten de har til å gjøre ting på sin egen måte. Det kan tyde på at kunnskapsarbeideres atferd og selvledelseskapasitet ikke nødvendigvis vil være tilpasset deres personlige situasjon, kapasitet og preferanser. Behov endrer seg dessuten over livsløpet, ikke minst gjelder det mulige helseproblemer, familierelaterte utfordringer, eller livsfaser. Det kan derfor ligge et potensial i at selv erfarne konsulenter og kunnskapsmedarbeidere jevnlig gjennomfører selvoberservasjon for å kartlegge egne selvledelsesbehov, og slik får oversikt over områder som er i ubalanse og krever justeringer. 
Når det gjelder hvilke selvledelsesstrategier som kan være særlig egnet for kunnskapsmedarbeidere og konsulenter, er det et vesentlig poeng at siden arbeidet i seg selv er kognitivt krevende, kan det være mer bærekraftig å benytte atferdsbaserte og strukturelle selvledelsesstrategier, snarere enn kognitive og mentale. Men siden flere av disse bygger på og forutsetter føre-var-planlegging og forutsigbarhet, er det viktig å være oppmerksom på faren for at dette spiller over i manglende fleksibilitet og samspillsevne. Det vil derfor være sentralt å diskutere dilemma mellom planlegging og fleksibilitet, og hvordan man skal håndtere hensynet til seg selv versus hensynet til andre når man utøver eller tilrettelegger for selvledelse.

Når virksomheter skal støtte kunnskapsmedarbeidere i å utvikle selvledelse (også omtalt som superledelse), er det en fordel om det allerede fins rollemodeller, mentorer og coacher som kan modellere aktuell atferd, håndtere verktøy og gi råd om fordeler og fallgruver (Manz, 1983, 1986). At sentrale personer som yter respekt i organisasjonen har en læringsorientert tenkemåte på egne vegne, og på vegne av aktuelle medarbeidere eller adepter som coaches i selvledelse, er også en forutsetning for vellykket superledelse (Amundsen, 2019). Gjennom å se på selvledelse som en prosess som aldri tar slutt eller er «ferdig», kan man sørge for jevnlige refleksjonsprosesser rundt tematikken og tilby skreddersydd trening og utviklingstiltak når det føles naturlig og nødvendig.

\section{Referanser}

Allvin, M., Mellner, C., Movitz, F. \& Aronsson, G. (2013). The diffusion of flexibility: Estimating the incidence of low-regulated working conditions. Nordic journal of working life studies, 3(3), 99-116. https://doi.org/10.19154/njwls.v3i3.3013

Amundsen, S. (2019). Empowerment $i$ arbeidslivet: et myndiggjøringsperspektiv på ledelse, selvledelse og medarbeiderskap. Oslo: Cappelen Damm Akademisk.

Amundsen, S. \& Martinsen, Ø. L. (2015). Linking empowering leadership to job satisfaction, work effort, and creativity: The role of self-leadership and psychological empowerment. Journal of Leadership \& Organizational Studies, 22(3), 304-323. https://doi.org/10.1177/1548051814565819

Bäcklander, G. (2019). Autonomous, yet aligned: Challenges of self-leadership in context (Doktoravhandling, KTH Royal Institute of Technology). Hentet fra http://www.diva-portal.org/smash/get/diva2:1348375/FULLTEXTo1.pdf 
Barsh, J., Cranston, S. \& Craske, R. A. (2008, 1. september). Centered leadership: How talented women thrive. The McKinsey Quarterly, 4, 35-48. Hentet fra https:// www.mckinsey.com/featured-insights/leadership/centered-leadership-howtalented-women-thrive

Baumeister, R. F. (2002). Yielding to temptation: Self-control failure, impulsive purchasing, and consumer behavior. Journal of consumer Research, 28(4), 670-676. https://doi.org/10.1086/338209

Baumeister, R. F., Bratslavsky, E., Muraven, M., \& Tice, D. M. (1998). Ego depletion: Is the active self a limited resource? Journal of personality and social psychology, 74(5), 1252.

Baumeister, R. F., Heatherton, T. F. \& Tice, D. M. (1994). Losing control: How and why people fail at self-regulation. San Diego, CA: Academic Press.

Baumeister, R. F., Tice, D. M., \& Vohs, K. D. (2018). The strength model of self-regulation: Conclusions from the second decade of willpower research. Perspectives on Psychological Science, 13(2), 141-145.

Baumeister, R. F., Vohs, K. D. \& Tice, D. M. (2007). The strength model of selfcontrol. Current directions in psychological science, 16(6), 351-355. https://doi. org/10.1111/j.1467-8721.2007.00534.x

Brun, P. H. \& Ejsing, M. (2010). Styrkebaseret ledelse: konkrete redskaber til at skabe effektive og sunde organisationer. Køvenhavn: Dansk Psykologisk Forlag.

Butler, T. \& Waldroop, J. (1999). Job sculpting: The art of retaining your best people. Harvard Business Review, 77(5), 144-152. Hentet fra https://hbr.org/1999/o9/jobsculpting-the-art-of-retaining-your-best-people

Chan, D. (2006). Interactive effects of situational judgment effectiveness and proactive personality on work perceptions and work outcomes. Journal of Applied Psychology, 91(2), 475-481. https://doi.org/10.1037/0021-9010.91.2.475

Cross, R., Rebele, R. \& Grant, A. (2016). Collaborative overload. Harvard Business Review, 94(1), 16. Hentet fra https://hbr.org/2016/o1/collaborative-overload

Danziger, S., Levav, J. \& Avnaim-Pesso, L. (2011). Extraneous factors in judicial decisions. Proceedings of the National Academy of Sciences of the United States of America, 108(17), 6889-6892. https://doi.org/10.1073/pnas.1018033108

Deci, E. L. \& Ryan, R. M. (2008). Self-determination theory: A macrotheory of human motivation, development, and health. Canadian psychology/Psychologie canadienne, 49(3), 182-185. https://doi.org/10.1037/aoo12801

Driskell, J. E., Copper, C. \& Moran, A. (1994). Does mental practice enhance performance? Journal of applied psychology, 79(4), 481-492. https://doi. org/10.1037/oo21-9010.79.4.481

Edmondson, A. C. \& Lei, Z. (2014). Psychological safety: The history, renaissance, and future of an interpersonal construct. Annual Review of Organizational 
Psychology and Organizational Behavior, 1(1), 23-43. https://doi.org/10.1146/ annurev-orgpsych-031413-091305

Empson, L. \& Langley, A. (2015). Leadership and professionals. I L. Empson, D. Muzio, J. Broschak \& B. Hinings (Red.), The Oxford handbook of professional service firms. Oxford: Oxford University press. https://doi.org/10.1093/ oxfordhb/9780199682393.013.11

Ent, M. R., Baumeister, R. F. \& Tice, D. M. (2015). Trait self-control and the avoidance of temptation. Personality and Individual Differences, 74, 12-15. https://doi. org/10.1016/j.paid.2014.09.031

Erhard, W. \& Jensen, M. C. (2013, 22. november). The four ways of being that create the foundation for great leadership, a great organization, and a great personal life. Harvard Business School NOM Unit Working Paper 14-027, Barbados Group Working Paper 13-03. http://dx.doi.org/10.2139/ssrn.2325077

Furtner, M. R., Sachse, P. \& Exenberger, S. (2012). Learn to influence yourself: Full range self-leadership training. Journal of the Indian Academy of Applied Psychology, 38(2), 294-304.

Gailliot, M. T., Baumeister, R. F., DeWall, C. N., Maner, J. K., Plant, E. A., Tice, D. M., Brewer, L. E. \& Schmeichel, B. J. (2007). Self-control relies on glucose as a limited energy source: Willpower is more than a metaphor. Journal of personality and social psychology, 92(2), 325-336. https://doi.org/10.1037/0022-3514.92.2.325

Grant, A. \& Rebele, R. (2017, 1. februar). Beat generosity burnout. Harvard Business Review, 2-24. Hentet fra https://hbr.org/cover-story/2017/o1/beat-generosityburnout

Hatchuel, A. (2002). 4 Sources of intensity in work organizations. I J. Forslin, P. Docherty \& A. B. Shani (Red.), Creating Sustainable Work Systems (1. utg.). New York: Routledge.

Hofmann, W., Baumeister, R. F., Förster, G. \& Vohs, K. D. (2012). Everyday temptations: An experience sampling study of desire, conflict, and self-control. Journal of Personality and Social Psychology, 102(6), 1318-1335. https://doi. org/10.1037/aoo26545

Houghton, J. D., Wu, J., Godwin, J. L., Neck, C. P. \& Manz, C. C. (2012). Effective stress management: A model of emotional intelligence, self-leadership, and student stress coping. Journal of Management Education, 36(2), 220-238. https://doi.org/10.1177/1052562911430205

Ipsen, C. \& Jensen, P. L. (2010). Causes of work-related stress and individual strategies in knowledge work. Kgs. Lyngby: DTU Management. https://doi. org/10.11581/dtu:00000084

Joo, B. K. \& Lim, T. (2009). The effects of organizational learning culture, perceived job complexity, and proactive personality on organizational commitment and 
intrinsic motivation. Journal of Leadership \& Organizational Studies, 16(1), 48-60. https://doi.org/10.1177/1548051809334195

Karp, T. (2016). Til meg selv. Det er ikke det jeg sier til andre, men hva jeg sier til meg selv. Om selvledelse. Oslo: Cappelen Damm Akademisk.

Kerr, S. \& Jermier, J. M. (1978). Substitutes for leadership: Their meaning and measurement. Organizational behavior and human performance, 22(3), 375-403. https://doi.org/10.1016/0030-5073(78)90023-5

Laloux, F. (2014). Reinventing organizations: A guide to creating organizations inspired by the next stage in human consciousness. Brüssel: Nelson Parker.

Lansmann, S. \& Klein, S. (2018). How much collaboration? Balancing the needs for collaborative and uninterrupted work (Research paper 118). Hentet fra https://aisel. aisnet.org/ecis2018_rp/118

Lovelace, K. J., Manz, C. C. \& Alves, J. C. (2007). Work stress and leadership development: The role of self-leadership, shared leadership, physical fitness and flow in managing demands and increasing job control. Human Resource Management Review, 17(4), 374-387. https://doi.org/10.1016/j.hrmr.2007.08.001

Lupu, I. \& Empson, L. (2015). Illusio and overwork: Playing the game in the accounting field. Accounting, Auditing and Accountability Journal, 28(8), 1310-1340. https://doi.org/10.1108/AAAJ-02-2015-1984

Manz, C. C. (1983). The art of self-leadership: Strategies for personal effectiveness in your life and work. New Jersey: Prentice-Hall.

Manz, C. C. (1986). Self-leadership: Toward an expanded theory of self-influence processes in organizations. Academy of Management review, 11(3), 585-60o. https://doi.org/10.2307/258312

Manz, C. C. (2015). Taking the self-leadership high road: Smooth surface or potholes ahead? Academy of Management Perspectives, 29(1), 132-151. https://doi. org/10.5465/amp.2013.0060

Manz, C. C. \& Sims Jr, H. P. (1980). Self-management as a substitute for leadership: A social learning theory perspective. Academy of Management review, 5(3), 361-367. https://doi.org/10.5465/amr.1980.4288845

Martijn, C., Alberts, H. J., Merckelbach, H., Havermans, R., Huijts, A. \& De Vries, N. K. (2007). Overcoming ego depletion: The influence of exemplar priming on self-control performance. European Journal of Social Psychology, 37(2), 231-238. https://doi.org/10.1002/ejsp.350

Mazmanian, M., Orlikowski, W. J. \& Yates, J. (2013). The autonomy paradox: The implications of mobile email devices for knowledge professionals. Organization Science, 24(5), 1337-1357. Hentet fra http://hdl.handle.net/1721.1/112333

Michel, A. (2014). Participation and self-entrapment A 12-year ethnography of Wall Street participation practices' diffusion and evolving consequences. The Sociological Quarterly, 55(3), 514-536. https://doi.org/10.1111/tsq.12064 
Mischel, W. (1977). The interaction of person and situation. Personality at the Crossroads: Current Issues in Interactional Psychology, 333, 352. https://doi.org/10.1037/0003-066X. 32.4.246

Neck, C. P. \& Houghton, J. D. (2006). Two decades of self-leadership theory and research. Journal of Managerial Psychology, 21(4), 270-295. https://doi.org/10.1108/ 02683940610663097

Neck, C. P. \& Manz, C. C. (2010). Mastering self-leadership: Empowering yourselffor personal excellence. New York: Pearson.

Palm, I. J. L. M. (2008). The relation between leadership and outcome variables. Follower personality as a moderator (Masteroppgave, Utrecht University). Hentet fra http://dspace.library.uu.nl/bitstream/handle/1874/31125/Palm\%200031445. pdf? sequence $=1$ \&isAllowed $=y$

Papavassiliou, G. \& Mentzas, G. (2003). Knowledge modelling in weakly-structured business processes. Journal of Knowledge Management, 7(2), 18-33. https://doi. org/10.1108/13673270310477261

Parker, S. K., Wall, T. D. \& Cordery, J. L. (2001). Future work design research and practice: Towards an elaborated model of work design. Journal of occupational and organizational psychology, 74(4), 413-440. Hentet fra http://citeseerx.ist.psu. edu/viewdoc/download?doi=10.1.1.552.7518\&rep=rep1\&type $=$ pdf

Pearce, C. L. \& Manz, C. C. (2005). The new silver bullets of leadership: The importance of self-and shared leadership in knowledge work. Organizational Dynamics, 34(2), 130-140. https://doi.org/10.1016/j.orgdyn.2005.03.003

Pearce, C. L. \& Manz, C. C. (2011). Leadership centrality and corporate social ir-responsibility (CSIR): The potential ameliorating effects of self and shared leadership on CSIR. Journal of Business Ethics, 102, Art. nr. 563. https://doi. org/10.1007/s10551-011-0828-7

Pérez-Zapata, O., Pascual, A. S., Álvarez-Hernández, G. \& Collado, C. C. (2016). Knowledge work intensification and self-management: the autonomy paradox. Work Organisation, Labour and Globalisation, 10(2), 27-49. https://doi. org/10.13169/workorgalaboglob.10.2.0027

Pina e Cunha, M., Pacheco, M., Castanheira, F. \& Rego, A. (2017). Reflexive work and the duality of self-leadership. Leadership, 13(4), 472-495. https://doi. org/10.1177/1742715015606511

Roberts, H. E. \& Foti, R. J. (1998). Evaluating the interaction between self-leadership and work structure in predicting job satisfaction. Journal of business and psychology, 12(3), 257-267. https://doi.org/10.1023/A:1025067128193

Rock, D. \& Schwartz, J. (2007). The neuroscience of leadership. Reclaiming Children and Youth, 16(3), 10-17.

Sampl, J., Maran, T. \& Furtner, M. R. (2017). A randomized controlled pilot intervention study of a mindfulness-based self-leadership training (MBSLT) on 
stress and performance. Mindfulness, 8(5), 1393-1407. https://doi.org/10.1007/ s12671-017-0715-0

Sandvik, A. M., Selart, M., Schei, V. \& Martinsen, Ø. L. (2019). Setting the scene: Partners' leadership behavior and employees' perceptions of work performance in professional service firms. Journal of Leadership \& Organizational Studies, 26(4), 441-453. https://doi.org/10.1177/1548051818781813

Schwartz, T. \& McCarthy, C. (2007). Manage your energy, not your time. Harvard Business Review, 85(10). Hentet fra https://hbr.org/2007/10/manage-your-energynot-your-time

Sidwell, A., \& Perry, M. (2019). Self-leadership training review. https://doi. org/10.31124/advance.7771175.v1

Sims Jr, H. P. \& Lorenzi, P. (1992). The new leadership paradigm: Social learning and cognition in organizations. Newbury Park, CA: Sage.

Sjåstad, H. \& Thorbjørnsen, H. (2018). Når selvkontrollen svikter: Kan dulting bidra til varig atferdsendring? Magma, 8, 59-66. Hentet fra https://www.magma.no/ nar-selvkontrollen-svikter-kan-dulting-bidra-til-varig-atferdsendring

Stewart, G. L., Courtright, S. H. \& Manz, C. C. (2011). Self-leadership: A multilevel review. Journal of Management, 37(1), 185-222. https://doi. org/10.1177/0149206310383911

Stewart, G. L., Courtright, S. H. \& Manz, C. C. (2019). Self-leadership: A paradoxical core of organizational behavior. Annual Review of Organizational Psychology and Organizational Behavior, 6, 47-67. https://doi.org/10.1146/annurevorgpsych-012218-015130

Swart, T. (2019). The source. Open your mind, change your life. London: Penguin Random House.

Thaler, R. H. \& Sunstein, C. R. (2008). Nudge: Improving decisions about health, wealth, and happiness. New Haven, CT: Yale University Press.

Thompson, G. \& Hatlevoll, K. (2019). Regi i eget liv. I L. Glasø \& G. Thompson (Red.), Selvledelse. Teori, forskning og praksis (s. 35-6o). Oslo: Gyldendal.

Unsworth, K. L., \& Mason, C. M. (2012). Help yourself: The mechanisms through which a self-leadership intervention influences strain. Journal of Occupational Health Psychology, 17(2), 235.

van Knippenberg, D., Dahlander, L., Haas, M. R. \& George, G. (2015). Information, attention, and decision making Academy of Management Journal, 58(3), 649-657. http://dx.doi.org/10.5465/amj.2015.4003

Velten, J., Ackerman, C., Hällstén, F. \& Tengblad, S. (2008). Medarbeiderskap: Fra ord til handling. Oslo: Universitetsforlaget.

Wadel, C. C. (2011). Om å lede seg selv sammen med andre. Selvledelse i medarbeidersamhandling. Sosiologi i dag, 36(1), 59-77. Hentet fra http://ojs. novus.no/index.php/SID/article/view/917/911 
Weick, K. E. (1996). Enactment and the boundaryless career: Organizing as we work. I M. B. ARthyr \& D. M. Rousseau (Red.), The boundaryless career: A new employment principle for a new organizational era (s. 40-57). Oxford: Oxford University Press.

Werr, A. \& Stjernberg, T. (2003). Exploring management consulting firms as knowledge systems. Organization studies, 24(6), 881-908. https://doi. org/10.1177/0170840603024006004

Williams, S. (1997). Personality and self-leadership. Human Resource Management Review, 7(2), 139-155. https://doi.org/10.1016/S1053-4822(97)90020-6 


\title{
Gårsdagens suksess - morgendagens begrensning? Strategisk relevant handlingsrom: En rikere forståelse av leders handlingsrom
}

\author{
Jarle Bastesen
}

Hoyskolen Kristiania

\section{Birthe Kåfjord Lange \\ Hoyskolen Kristiania}

\begin{abstract}
Managerial discretion is said to be a fundamental condition for effective leadership. Studies of managerial discretion have to a large degree focused on the magnitude of managers' discretion and how different factors influence managers' perceived level of discretion (Hambrick, 2007; Hambrick \& Finkelstein, 1987; Hutzschenreuter \& Kleindienst, 2013). In this chapter, we argue that it is insufficient to study the size of managers' room for discretion. We also need to understand the content included in leaders' discretionary rooms. In a study of ten successful logistics companies, one of which was studied more in-depth, we find that the managers perceive their room for managerial discretion as large. However, the alternatives considered are to a large extent operational and short-term, at the expense of more long-term, strategically relevant alternatives facing future challenges. Hence, we develop the concept "strategically relevant managerial discretion", which, in addition to the alternatives that managers are aware of and that are acceptable for the mangers' stakeholders, also includes a new dimension: to what extent the alternatives are strategically relevant for future challenges. We conclude the chapter by pointing out interesting directions for future research, including a call for empirical studies of the conceptual model developed in this chapter.
\end{abstract}

Keywords: managerial discretion, ambidextrous organizations, strategic change

Sitering av denne artikkelen: Bastesen, J. \& Lange, B. K. (2020). Gårsdagens suksess - morgendagens begrensning? Strategisk relevant handlingsrom: En rikere forståelse av leders handlingsrom. I J. Bastesen, B. K. Lange, H. E. Næss \& A. N. Thon (Red.), Ledelse av mennesker i det nye arbeidslivet (Kap. 4, s. 111134). Oslo: Cappelen Damm Akademisk. https://doi.org/10.23865/noasp.118.ch4 Lisens: CC-BY 4.0. 


\section{Innledning}

Leders handlingsrom hevdes å være en fundamental betingelse som avgjør hvor stor betydning ledelse kan ha (Espedal, 2017; Espedal \& Kvitastein, 2012): lite handlingsrom gir mindre mulighet for å påvirke resultater, mens større handlingsrom øker potensiell betydning av ledelse. I debatten om lederes handlingsrom diskuteres det ofte hvordan en kan øke størrelsen på dette, basert på en implisitt antakelse om at større handlingsrom er bedre enn lite handlingsrom. Men, er det slik at størrelsen på handlingsrommet nødvendigvis er en god indikator på hvor relevant handlingsrommet er for virksomhetens fremtidige utfordringer? For å undersøke dette stiller vi følgende spørsmål: Hvilken betydning har stort opplevd handlingsrom for lederes håndtering av virksomhetens strategiske utfordringer? Hva er et strategisk relevant handlingsrom? I dette kapittelet argumenterer vi for at det ikke er tilstrekkelig å diskutere størrelsen på lederes handlingsrom, vi må også legge vekt på handlingsrommets innretning.

Ifølge Tushman og O’Reilly (1996) møter organisasjoner og ledere som erfarer suksess en utfordring i den såkalte suksessfellen. Det innebærer at man fokuserer på å utnytte kunnskap, produkter og/eller teknologi som har gitt suksess, på bekostning av å utforske nye muligheter. I møte med mer radikale skift, f.eks. i teknologi eller marked, må imidlertid virksomheten klare å endre seg mer radikalt for å opprettholde gode resultater også i fremtiden.

Sooner or later, discontinuities upset the congruence that has been a part of the organization's success. Unless their competitive environment remains stable - an increasingly unlikely condition in today's world - firms must confront revolutionary change. (Tushman \& O’Reilly, 1996, s. 12)

Basert på utsiktene til en mer usikker fremtid for mange virksomheter i dag, vil vi hevde at studier av lederes handlingsrom må dreies fra en undersøkelse av størrelse (Andersen, 2017) og mot i hvilken grad alternativene som lederne diskuterer er strategisk relevante, ikke bare i dag, men også i møte med fremtidige utfordringer. Vi introduserer dermed begrepet strategisk relevant handlingsrom, som handler om i hvilken grad 
lederne er oppmerksomme på og diskuterer mulige fremtidige strategiske utfordringer, i tillegg til dagens utfordringer.

Hambrick og Finkelstein (1987) og Hutzschenreuter og Kleindiensts (2013) rammeverk om lederes handlingsrom utgjør et sentralt teoretisk utgangspunkt for dette kapitlet. Dette kombineres med Tushman og O'Reillys (1996) teorier om hvordan suksessfellen kan hindre organisasjoners ambideksteritet (tohendighet). Vi drøfter videre hvordan både historiske faktorer (eksempelvis organisasjonens tidligere resultater og erfaringer) og nåværende faktorer (eksempelvis konkurransesituasjon og opplevd tidspress) begrenser hvilke valgmuligheter lederne oppfatter er relevante for å ta grep om fremtidige utfordringer (Bansal, Reinecke, Suddaby \& Langley, 2019).

For å utforske hvordan disse aspektene ved lederes handlingsrom utspiller seg i praksis, har vi gjennomført en studie av 10 selskaper i logistikkbransjen. Logistikk og spedisjon er valgt siden bransjen har vært preget av stadige inkrementelle endringer over tid, men som ifølge Carlin et al. (2015) med stor sannsynlighet vil oppleve radikale endringer fremover. Sannsynligheten for at lagermedarbeidere blir erstattet av automatisering og digitalisering anses så høy som 80-90 \%. Å forberede seg på radikal endring, samtidig som daglig drift stadig må effektiviseres, representerer derfor en kritisk utfordring for logistikkbransjen og gir en interessant kontekst for vår studie.

\section{Teori}

\section{Handlingsrom}

I et tidlig bidrag ble lederes handlingsrom definert som mulighetene ledere har til å foreta valg innenfor rammen av formelle jobbkrav og begrensninger (Stewart, 1982). Hambrick \& Finkelstein (1987) introduserte begrepet managerial discretion, ofte oversatt til leders handlingsrom på norsk, som vektlegger valgmulighetene ledere opplever innenfor gitte rammer i leders kontekst. Ifølge Hambrick og Finkelstein (1987) består leders handlingsrom av tre elementer: omgivelsene, intern organisering og karakteristika ved lederen. Hutzschenreuter og Kleindienst (2013) bygger videre på Hambrick og Finkelsteins definisjon av leders 
handlingsrom, og definerer leders handlingsrom som en kombinasjon av to faktorer: De alternativene en leder er klar over, og de alternativene som er akseptable for sentrale aktører i omgivelsene (Hutzschenreuter \& Kleindienst, 2013, s. 266). Det vil altså si at leders handlingsrom (LH) betraktes som en funksjon av leders oppmerksomhet (LO; hvilke alternativer eller valgmuligheter en leder er klar over) og de alternativene det er aksept for blant interessenter med makt til å definere hva som er akseptabelt (AA) (se figur 1 under). Handlingsrommet defineres som det feltet hvor alternativene en leder er klar over (LO) og alternativer som er akseptable for omgivelsene (AA) overlapper.
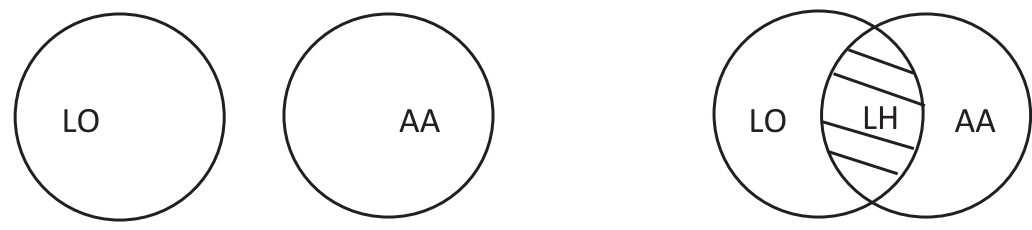

LO = Leders oppmerksomhet - valgmuligheter leder er klar over

$A A=$ Alternativene det aksept for blant interessentene

$\mathrm{LH}=$ Leders handlingsrom

Figur 1 Leders handlingsrom, basert på Hutzschenreuter og Kleindienst (2013).

Forfatterne lister opp 16 variabler de hevder påvirker lederes handlingsrom på ulike vis. De etterlyser imidlertid mer empirisk forskning for å klargjøre hvordan de beskrevne sammenhengene mellom ulike variabler faktisk fungerer i praksis. Vi vil i dette kapitlet besvare etterlysningen gjennom å utforske nærmere noen utvalgte variabler og hvilken betydning de har for lederes handlingsrom. Andersen (2017) hevder at mangelen på felles definisjon av begrepet gjør det vanskelig å måle empirisk, og at det derfor er lite interessant å studere størrelse eller andre aspekter ved lederes handlingsrom. Vi er enig med Andersen i behovet for klarere forståelse av begrepet handlingsrom. Men, der Andersen konkluderer 
med at handlingsrom ikke er interessant å studere videre, ser vi derimot behov for å utvide forståelsen av aspekter ved dette som til nå har vært mindre studert: nemlig i hvilken grad lederes handlingsrom er orientert mot alternativer som er strategisk relevant for virksomhetenes fremtidige utfordringer.

\section{Tohendighet}

March (1991) hevder at organisasjoner bør balansere stadige forbedringer og mer effektiv utnytting av det eksisterende med utforskning av nye strategiske muligheter og nyskapning. Organisasjoner som mestrer å balansere utnytting og utforsking og etablerer egne strukturer for å sikre nyskapning, kalles tohendige («ambidextrous», se Tushman \& O'Reilly, 1996). En sentral utfordring for mange ledere er imidlertid å finne tid og ha kapasitet til begge deler; både nyskapning og effektiv utnytting. Tidspress, definert som «people's sense of externally imposed urgency to accomplish tasks» (Staudenmayer, Tyre \& Perlow, 2002, s. 588), er ofte en kritisk faktor for ledere (Perlow, 1999) som begrenser opplevde muligheter til å balansere nyskapning og effektiv utnytting.

Ifølge Duncan (1979) må organisasjoner foreta strukturelle endringer og organisatoriske tiltak for å legge til rette for tohendighet. En organisasjon kan for eksempel etablere to ulike strukturer i samme organisasjon (strukturell tohendighet), skifte mellom perioder hvor virksomheten legger vekt på utforsking og utnytting (sekvensiell tohendighet), eller legge til rette for at ansatte kan balansere sin arbeidshverdag mellom utnyttings- og utforskingsaktiviteter (Birkinshaw \& Gibson, 2004).

Med henvisning til March (1991) hevder Hutzschenreuter og Kleindienst (2013) at ledere som er opptatt av å sikre utforskende tilnærminger og nyutvikling vil ha større handlingsrom enn ledere som fokuserer på mer utnyttende tilnærminger og inkrementelle forbedringer. Dette begrunnes i at utnytting bygger på eksisterende kunnskapsbase, mens utforsking i større grad utvider leders kunnskapsbase. 
Hutzschenreuter og Kleindienst (2013) peker på en rekke faktorer de mener øker virksomheters utforskende tilnærminger og nyutvikling. For det første fremheves betydningen av god informasjonsflyt mellom ulike ledernivåer med tanke på læring på tvers. En annen faktor er slakk («slack») i organisasjonen. Slike ressurser kan eksempelvis være en finansiell buffer, tid, personell, m.m. Slakk muliggjør mer eksperimentelle tilnærminger uten at man trenger være så redd for å mislykkes. Penrose (1959) argumenterer for at en organisasjon trenger slakk-ressurser for å initiere innovative aktiviteter og organisasjonsutvikling, og at slike ressurser er spesielt viktige å ha tilgjengelig når omgivelsene endres. For det tredje hevder Hutzschenreuter og Kleindienst (2013) at selskaper som er mer strategisk utforskende og preget av en «oppfinner-tilnærming» («prospector») (Miles, Snow, Meyer \& Coleman, 1978) også vil oppleve $ø$ kt handlingsrom.

\section{Tidligere suksess}

En annen faktor som påvirker lederhandlingsrom er tidligere suksess. Ledere som har opplevd tidligere suksess blir ofte mer opptatt av det som har fungert godt tidligere enn av å utforske nye løsninger for fremtiden (Tushman \& O’Reilly III, 1996). Ifølge Hutzschenreuter og Kleindienst (2013) minker lederens handlingsrom dersom selskapet har hatt suksess, fordi lederen i mindre grad vil vurdere andre alternativer enn de som har gitt suksess så langt. Når virksomheter vokser og blir eldre, har de en tendens til å «stivne» både strukturelt og kulturelt (Hannan \& Freeman, 1984). Dette er et poeng som også ble diskutert da teorien om lederes handlingsrom ble introdusert av Hambrick og Finkelstein (1987). Vi mener det også er en sammenheng mellom forståelse av det som har voert (historisk suksess), det som er nå (opplevd handlingsrom), og hvilke fremtidige strategiske muligheter lederne ser (Ancona, Goodman, Lawrence \& Tushman, 2001). Organisasjonsmedlemmenes forståelse av fortid er ifølge Mead (1932; i Hernes, Simpson \& Söderlund, 2013) sosialt konstruert og bygd på historisk utvikling i organisasjonen. 


\section{Endring i bransjedynamikk}

Ifølge Duncans (1972) rammeverk for usikkerhet vil en virksomhet som befinner seg i dynamiske omgivelser oppleve større usikkerhet en de som har stabile omgivelser. En virksomhet som opererer i dynamiske omgivelser vil stadig måtte tilpasse seg endringer i omgivelsene. Å operere i en dynamisk og uforutsigbar industri vil ifølge Hutzschenreuter og Kleindienst (2013) presse CEO og topplederteamet til å være mer nytenkende og søke etter flere alternativer som øker deres handlingsrom. For å tilpasse seg dynamiske omgivelser, kan virksomheten strukturere seg mer organisk (Burns \& Stalker, 1961, i Shafritz, Ott \& Jang, 2015). Organisk struktur kjennetegnes av desentralisering av ansvar og myndighet, mer horisontal kommunikasjon og samhandlig, samt vektlegging av samarbeid og fleksibel utnyttelse av arbeidskraft. Dette står i kontrast til en mer mekanistisk og byråkratisk struktur som i større grad kjennetegnes av klar arbeidsdeling, spesialisering, formalisering, standardisering av arbeidsprosesser, sentralisering av beslutningsmyndighet og dermed et tydeligere hierarkisk system.

Dersom man opererer i stabile omgivelser er virksomheten utsatt for få endringer, og virksomheten kan struktureres mer mekanistisk eller byråkratisk. Logistikk er en tradisjonell bransje hvor det har vært få endringer og de har skjedd gradvis. I et stabilt marked er inkrementelle endringer tilstrekkelig for stadig å knipe marginer og opprettholde suksessen (Tushman \& O'Reilly, 1996). Logistikkbransjen vil sannsynligvis oppleve radikale endringer fremover (Carlin et al., 2015).

Ifølge Hannan og Freeman $(1977,1984)$ er det vanskelig for organisasjoner å endre seg radikalt. Dette er fordi det vil være stor motstand mot endringer internt i organisasjoner, og i tillegg er organisasjoner, spesielt de som har vært etablert en stund, innrettet mot stabilitet. Som nevnt er de ofte mer byråkratiske og mekanistiske, noe som skaper strukturell og kulturell treghet i organisasjonen, og gjør kostnadene ved endringer større. Ved store endringer i måten bransjen opererer på, eksempelvis introduksjon av radikale innovasjoner, måten man opererer på eller endring av teknologi, vil mange etablerte selskaper få store problemer (Tushman \& Murmann, 1998). 
Hutzschenreuter og Kleindienst (2013) hevder at det å operere i en bransje i vekst, eller hvor det er store vekstmuligheter, er hemmende på lederes handlingsrom. Dette fordi et slikt «vekstvennlig» marked reduserer truslene mot virksomheten, og dermed minker presset mot utforskende aktiviteter som utvider alternativene lederne er klar over.

\section{Oppsummering av teori}

Oppsummert finner vi at en strategisk utforskende tilnærming til markeder, produkter og tjenester, samt det å operere i dynamiske omgivelser og med lite suksess, fører til at selskapets ledelse har et større handlingsrom. Dette understøttes av mekanismer som en oppfinner-orientering, god informasjonsdeling, og tilgjengelige slakk-ressurser i organisasjonen. En utnyttende, forsvarer-orientert tilnærming, tidligere suksess og vekt på inkrementelle forbedringer, samt å operere i en bransje i vekst, er hemmende på ledelsens handlingsrom. I motsetning til Hambrick og Finkelstein (1987) og Hutzschenreuter og Kleindienst (2013) ser vi bort fra toppleders personlighet og et individuelt perspektiv i vår diskusjon av handlingsrom. Vi tar et organisasjonsperspektiv, og studerer lederne som gruppe, samt et omgivelsesperspektiv, som ser på dynamikken i bransjen de opererer $i$.

I tillegg til disse faktorene finner vi teoretisk støtte for at at tidspress (Perlow, 1999; Staudenmayer et al., 2002), samt strukturell og kulturell treghet kan være hemmende på ledernes handlingsrom (Hannan \& Freeman, 1984; Hutzschenreuter \& Kleindienst, 2013; Tushman \& O’Reilly III, 1996). Videre ser vi at det er flere faktorer som kan påvirke handlingsrommet i ulike retninger. For det første peker vi på virksomhetens sosialt konstruerte forståelse av fortid, nåtid og fremtidige muligheter. Denne forståelsen kan også knyttes opp mot den kulturelle tregheten som utvikles i enkelte organisasjoner. For det andre peker vi på organisasjonsstrukturens rolle, som enten kan støtte eller hemme strategisk orientering, samt utvikling av strukturell treghet i organisasjonen. Et sentralt grunnpremiss for mange virksomheter som står overfor mulige store endringer er behovet for å balansere utforsking og utnytting, hvor det ikke er noe enten-eller. Det blir da vanskelig å diskutere handlingsrom 
opp mot et ideal som sier at ledere bør ha en rent utforskende, oppfinner-orientert tilnærming, helst i dynamiske omgivelser og uten tidligere suksess. Handlingsrom er ikke en konstant størrelse, men påvirkes over tid av eksempelvis ulike aktiviteter ledere gjennomfører, organisatorisk «treghet» eller endringer i omgivelser (Finkelstein \& Peteraf, 2007).

\section{Metode}

Studien dette kapitlet er bygget på består av to deler, som begge har til hensikt å utvikle bedre innsikt og forståelse for ulike aspekter knyttet til lederes handlingsrom. Vi har derfor valgt en kvalitativ tilnærming som gir «in-depth inquiry into a topic or phenomenon within its reallife setting» (Yin, 2018, s. 16) i vår studie av 10 suksessrike selskaper i logistikkbransjen.

Studien består av to deler: observasjoner fra strategiske diskusjoner i totalt 10 logistikkselskaper, og mer inngående casestudie i ett av de 10 selskapene.

\section{Bakgrunn for valg av bransje og case}

Logistikkbransjen har vært preget av relativt høy grad av stabilitet over tid, men står nå overfor ny, mer usikker og dynamisk utvikling av bransjen. Dette skyldes blant annet utvikling av ny teknologi (eksempelvis heldigitaliserte lager), økt konkurranse (eksempelvis Amazons planlagte etablering i Sverige), og endret kundeatferd (eksempelvis økt netthandel). Selv om marginene har vært små og konkurransen i logistikkbransjen hard, har rammene i bransjen tidligere vært relativt forutsigbare. I design av studien har vi blant annet ønsket å utforske betydningen av endringer i bransjekontekst og -dynamikk for lederes handlingsrom. Ifølge Dubois og Gadde (2002, referert i Saunders, Lewis \& Thornhill, 2019) er inngående casestudier den beste måten å forstå interaksjonen mellom et fenomen (her: lederes handlingsrom) og konteksten som omgir fenomenet (her: endringer i bransjedynamikk). Vi har derfor valgt å studere ett av de ti selskapene mer inngående. Dette selskapet er valgt fordi det har hatt spesielt stor suksess over tid 
i stabile bransjeomgivelser. Når hele logistikkbransjen nå står overfor endringer, blir det dermed ekstra interessant å utforske hvordan lederne opplever eget handlingsrom i dette selskapet nå som de står overfor mulige endringer.

\section{Del 1: Observasjonsdata fra strategiske diskusjoner i totalt 10 logistikkselskaper}

Ifølge Yin (2018) er eksplorerende casestudier en hensiktsmessig tilnærming i deduktive studier hvor forskere tar utgangspunkt i teoretiske antakelser som testes ut i empiriske settinger. Selv om rammeverket til Hutzschenreuter og Kleindienst (2013) utgjør et viktig fundament for denne studien, har vi ikke gjennomført klassisk testing av teorirammeverket. I stedet har vi søkt å utforske og få en rikere forståelse for hvordan ulike aspekter ved rammeverket kan forstås og fortolkes. Ifølge Ridder et al. (referert i Saunders et al., 2019) er casestudier også egnet til denne typen studier. Alle de 10 selskapene har gjennomført samme workshop, innledet med diskusjon av selskapets styrker og utfordringer. Deltakerne (adm. direktør, toppledergruppe og mellomledere fra hvert selskap) kom opp med alle punktene på listen selv, uten hjelp eller innspill fra fasilitator. En av forskerne observerte diskusjonene, og skrev ned samtlige innspill fortløpende. Innspillene ble først listet opp ordrett for hvert selskap. For å sikre «interrater reability» (LeBreton \& Senter, 2008) ble listene kodet av to forskere. Deretter ble listene sammenlignet, slått sammen og samlet $i$ tabeller (se tabell 1 og 2).

En styrke ved denne tilnærmingen er at den gir et godt inntrykk av hva ledergruppene selv mener er deres styrker og utfordringer, uten påvirkning. En mulig svakhet ved metoden er at lederne kan ha påvirket hverandres svar underveis, enten ved at de første innspillene ble førende for resten (kjent fenomen fra brainstorming), eller ved at innspill fra spesielt innflytelsesrike ledere kan ha påvirket de andre ledernes svar.

\section{Del 2: Dybdecase}

I ett av selskapene har vi gått mer i dybden og gjennomført intervjuer med CEO, toppledergruppen, mellomledere og flere ansatte. Til sammen har vi gjennomført 16 semistrukturerte intervju med lydopptak som 
senere ble transkribert (totalt 134 sider transkribert tekst). Denne studien bygger på etablerte teorier, men vi ønsket å utvide forståelsen av enkelte variabler og sammenhenger. Det var derfor viktig å være åpen for alle synspunkter, opplevelser eller erfaringer som respondentene kom med. Det gir semistrukturerte intervjuer gode muligheter for (Klenke, 2008). Samtaleguiden var bygget opp rundt tema som, basert på etablert teori, er antatt å være sentrale for lederes handlingsrom, men med rom for å forfølge spesielle innspill, kommentarer eller interesser hos respondentene. Intervjuene ble gjennomført på respondentenes arbeidssted for å unngå å skape en unødvendig formell og kunstig ramme rundt samtalene. Før oppstart ble respondentene lovet anonymitet, også internt mellom ulike respondenter, og informert om at det var frivillig å delta. I noen av intervjuene var vi flere forskere til stede samtidig, andre ganger intervjuet vi en og en.

I tillegg til 16 dybdeintervjuer, gjennomførte vi flere uformelle og kortere intervjuer. Disse ble ikke tatt opp, men vi noterte ned stikkord. Videre observerte vi lederne i ulike aktiviteter i virksomheten fordelt over to dager. Observasjoner fremheves som en lite benyttet metode i studier av ledelse og organisasjon (Saunders et al., 2019, s. 378), men som kan gi forskere bedre forståelse for informasjon fremkommet eksempelvis gjennom intervjudata. Selv om observasjonene i denne studien var relativt kortvarige, bekreftet det vi observerte ett av hovedfunnene våre: nemlig det store fokuset både lederne og en samlet organisasjon hadde på stadig større effektivitet, tempo og presisjon.

I analyse av intervjuene benyttet vi en tilnærming inspirert av tematisk analyse (Braun \& Clarke, 2006). Vi gjorde oss først kjent med datamaterialet hver for oss gjennom å lytte til deler av intervjuene på nytt, og lese gjennom alle transkriptene flere ganger. Deretter ble dataene kodet etter tydelige tema som fremkom på tvers av intervjuene. Enkelte tema var lette å observere og tydelige, som eksempelvis det sterke operative fokuset blant lederne. Andre tema krevde mer inngående jobbing med dataene, eksempelvis sammenhengen mellom stort opplevd handlingsrom og manglende oppmerksomhet mot fremtidige utfordringer. Alternative forklaringer ble drøftet, og noen måtte forkastes fordi de var for vage eller hadde for mange ulike betydninger (Saunders et al., 2019). I de 
følgende delene av kapitlet vil vi nå presentere resultater og drøfte hvilken innsikt vi kan trekke ut av studien.

\section{Resultat og drøfting}

\section{Presentasjon av funn}

Hvert av de 10 selskapene vi har observert har gjennomført samme workshop, hvor de innledet med en diskusjon av selskapets opplevde styrker og utfordringer. Tabell 1 viser en oppsummering av styrkene selskapene kom frem til.

Tabell 1 Selskapenes opplevde styrker (hva de er gode på i dag eller har blitt bedre på de siste par årene)

\begin{tabular}{|l|c|c|c|c|c|c|c|c|c|c|c|}
\hline \multicolumn{10}{|c|}{ Våre styrker: Hva vi er gode på } \\
\hline Organisasjon nummer & 7 & 2 & 3 & 4 & 5 & 6 & 7 & 8 & 9 & 10 & Sum \\
\hline Effektiv drift & $\mathrm{x}$ & $\mathrm{x}$ & $\mathrm{x}$ & $\mathrm{x}$ & $\mathrm{x}$ & $\mathrm{x}$ & $\mathrm{x}$ & $\mathrm{x}$ & $\mathrm{x}$ & $\mathrm{x}$ & 10 \\
\hline Involvering av organisasjonen & $\mathrm{x}$ & $\mathrm{x}$ & & $\mathrm{x}$ & $\mathrm{x}$ & & & & & & 4 \\
\hline Felles, tydelige mål & & $\mathrm{x}$ & & & $\mathrm{x}$ & & $\mathrm{x}$ & & & & 3 \\
\hline Kommunikasjon mellom teamledere & $\mathrm{x}$ & & $\mathrm{x}$ & & $\mathrm{x}$ & & & & & & 3 \\
\hline Endring/nyskaping & & & $\mathrm{x}$ & $\mathrm{x}$ & & $\mathrm{x}$ & & & & & 3 \\
\hline Fungerende ledergruppe & & & & & & $\mathrm{x}$ & $\mathrm{x}$ & & & & 2 \\
\hline Samarbeid mellom avdelinger & & & & & & $\mathrm{x}$ & & $\mathrm{x}$ & & & 2 \\
\hline Vertikal kommunikasjon & & & $\mathrm{x}$ & & & & & & & & 1 \\
\hline Sum & 3 & 3 & 4 & 3 & 4 & 4 & 3 & 2 & 1 & 1 & \\
\hline
\end{tabular}

Alle selskapene er logistikkselskaper. Det innebærer at de får varer inn som skal lagres, for deretter å plukkes ned og sammenstilles for videre forsendelser. Det er et mål at varestrømmen går så effektivt som overhodet mulig, og at varer ikke blir liggende for lenge på lager. Den aller viktigste styrken selskapene rapporterer om er også knyttet til effektiv drift. Selskapene bruker ulike beskrivelser av dette, som «effektive arbeidsprosesser»; «vi er gode på daglig drift»; «vi er gode på logistikk»; «vi er operativt gode». Alle selskapene vurderer selskapenes største styrke som gode på effektiv drift.

Det var større variasjon i hvilke andre egenskaper som ble fremhevet som styrker. Noen mente de var gode på å involvere hele organisasjonen, 
der målet er å fremstå som et kollektiv. Utsagn i denne kategorien inkluderer for eksempel «vi inkluderer i større grad, har gått fra JEG til VI», «vi har en kultur for mobilisering - alle er med og drar lasset», «vi er ikke ferdig før alle er ferdig» og «vi er gode til å stå skulder ved skulder i daglig drift».

En annen styrke som fremheves, er godt samarbeid og kommunikasjon mellom teamlederne. Denne kommunikasjonen og samarbeidet handler imidlertid om å løse diverse utfordringer i daglig drift. Bare to selskap meldte om god kommunikasjon / godt samarbeid mellom avdelinger (på tvers av verdikjeden), og bare ett selskap trakk frem at den vertikale kommunikasjonen i selskapet var god.

\section{Utfordringer}

Tabell 2 Selskapenes opplevde strategiske utfordringer (hva de bør bli bedre på fremover)

\begin{tabular}{|l|c|c|c|c|c|c|c|c|c|c|c|}
\hline \multicolumn{1}{|c|}{ Strategiske utfordringer: Kan bli bedre på } \\
\hline Organisasjon nummer & 7 & 2 & 3 & 4 & 5 & 6 & 7 & 8 & 9 & 10 & Sum \\
\hline Effektiv drift & $\mathrm{x}$ & $\mathrm{x}$ & & $\mathrm{x}$ & & $\mathrm{x}$ & $\mathrm{x}$ & $\mathrm{x}$ & $\mathrm{x}$ & $\mathrm{x}$ & 8 \\
\hline Samarbeid mellom avdelinger & $\mathrm{x}$ & $\mathrm{x}$ & & $\mathrm{x}$ & & $\mathrm{x}$ & $\mathrm{x}$ & & & $\mathrm{x}$ & 6 \\
\hline Beslutningsgrunnlag & & $\mathrm{x}$ & & $\mathrm{x}$ & $\mathrm{x}$ & & $\mathrm{x}$ & $\mathrm{x}$ & & $\mathrm{x}$ & 6 \\
\hline Vertikal kommunikasjon & & & $\mathrm{x}$ & & $\mathrm{x}$ & $\mathrm{x}$ & $\mathrm{x}$ & & $\mathrm{x}$ & & 5 \\
\hline Trivsel/miljø/kultur & & & & $\mathrm{x}$ & & $\mathrm{x}$ & & $\mathrm{x}$ & $\mathrm{x}$ & $\mathrm{x}$ & 5 \\
\hline Endring/nyskaping & $\mathrm{x}$ & & & $\mathrm{x}$ & $\mathrm{x}$ & & & $\mathrm{x}$ & & & 4 \\
\hline Balansere drift og utvikling & & & & & $\mathrm{x}$ & & & $\mathrm{x}$ & $\mathrm{x}$ & $\mathrm{x}$ & 4 \\
\hline Involvering/forankring & & & $\mathrm{x}$ & & $\mathrm{x}$ & & $\mathrm{x}$ & & & & 3 \\
\hline Ledelse & $\mathrm{x}$ & & & & & & & & $\mathrm{x}$ & & 2 \\
\hline Lære av andre selskaper & & & & & & & $\mathrm{x}$ & & & $\mathrm{x}$ & 2 \\
\hline Sum & 4 & 3 & 2 & 5 & 5 & 4 & 6 & 5 & 5 & 6 & \\
\hline
\end{tabular}

I tabell 2 ser vi at seks av ti selskaper melder om at de kan bli bedre på kommunikasjon og samarbeid mellom avdelinger (på tvers av verdikjeden), inkludert det ene selskapet som også mente de var gode på det. Når lederne utdyper behovet for samhandling mellom avdelingene/teamene, forklarer de at dette handler om behov for å utvikle interne prosesser. Våre intervjuer i ett av selskapene indikerer også at det er effektivitetsgevinster 
å hente gjennom bedre samarbeid og koordinering på tvers av verdikjeden. Vi ser også at nesten samtlige (åtte av ti) selskaper påpeker at selv om de er gode på drift, må de stadig bli bedre, og at de fremdeles kan hente ut større effektiviseringsgevinster. En stor andel av selskapene rapporterer at den vertikale kommunikasjonen i selskapene kan bli bedre, på ulike vis. Videre er de opptatt av å forbedre interne prosesser, som beslutningsprosesser og involvering, samt å forbedre arbeidsmiljøet på arbeidsplassen og bli bedre på ledelse.

En del av selskapene uttrykker en viss bekymring over at de har lav oppmerksomhet for utforsking. Dette vises i utsagn om at de trenger å bli bedre på endringer og nyskaping, og at noen mener de må ha bedre balanse i hensynet mellom daglig drift (utnytting) og utforsking (nyskaping). Utsagn som indikerer dette er «vi kan bli bedre på endringsvilje», «vi må bli flinkere til å balansere drift og utvikling/endring», «vi må bli flinkere å finne nye løsninger» og «vi må løfte blikket fra daglig drift».

Syv av selskapene diskuterte også fremtidige utfordringer som kan utgjøre en trussel for selskapene. Ensidig driftsorientering er en av disse. Et utsagn som illustrerer dette er «fokus på drift bremser mulighet for utvikling». To av selskapene advarer mot noe av det samme når de påpeker at det som gjør de gode (drift), også er en fare dersom de lener seg for godt til rette. I det ene selskapet uttalte de at «vi hviler kanskje litt for mye på laurbærene», og i det andre selskapet påpekte de at «det som er bra i dag er kanskje ikke godt nok i morgen». Noen peker på at en fare i organisasjonen er konsensus og at ingen stiller de kritiske spørsmålene. «Vi har en 'kjøre på' kultur - men hva med de kritiske spørsmålene?» er et av utsagnene.

Det er få som har blikk utenfor organisasjonen, men et par selskaper påpekte at de kunne bli bedre på å lære av andre selskaper. I hovedsak ser vi at selskapene primært har et internt fokus.

\section{Handlingsrom}

I dybdeintervjuene og observasjonene i ett selskap fikk vi mulighet til å dykke dypere inn i noen av temaene. Vi var blant annet opptatt av i 
hvilken grad lederne opplevde at de hadde handlingsrom; om de hadde muligheter til å ta selvstendige valg og om de fikk tid og ressurser til å utnytte dette handlingsrommet. De fleste lederne rapporterte at de opplevde å ha stort handlingsrom, de hadde muligheter til å ta selvstendige valg og de mente de hadde gode muligheter til å utnytte handlingsrommet om de ville. Men, intervjuene viste også at handlingsrommet er begrenset til å handle om effektiv daglig drift. I daglig drift handler teamledernes handlingsrom om å utforske alternativer og finne forbedringer innenfor rammene av å løse saker knyttet til daglig drift, og løse operative problemstillinger. Lederne fremstod imidlertid ikke som særlig bevisst på denne begrensningen, det virket som om rammene var mer eller mindre tatt for gitt.

\section{Diskusjon}

Vi stilte innledningsvis to forskningsspørsmål som vi i det følgende vil diskutere:

1. Hvilken betydning har stort opplevd handlingsrom for lederes håndtering av virksomhetens strategiske utfordringer?

2. Hva er strategisk relevant handlingsrom?

\section{Betydningen av stort opplevd handlingsrom}

Resultatene i vår studie viser tydelig at selskapene har et sterkt fokus på operativ drift, mens de har lite oppmerksomhet rettet mot utforsking av nye løsninger. I en bransjekontekst preget av en forventning om raskere endring fremover, vil det være viktig for selskapene vi har studert å evne å orientere seg mot mulighetene og utfordringene dette medfører. Selskapene fremstår imidlertid som lite orientert mot denne fremtiden. Basert på Hutzschenreuter \& Kleindienst (2013) kunne man forvente at det medførte at lederne ville rapportere om lite handlingsrom til å utvikle selskapet og lederskapet fremover, men lederne sier selv at de har stort handlingsrom. De kan gjøre de endringene de mener er fornuftige, det er stor takhøyde for å ta opp problemstillinger og få til endringer, og de har 
stor frihet til å forme aktivitetene slik de mener er best. Et viktig spørsmål blir da: Hvilket handlingsrom er det egentlig lederne faktisk opplever å ha?

Ifølge Hutzschenreuter \& Kleindienst (2013) minker lederes handlingsrom dersom ledere er opptatt av utnytting, inkrementelle endringer, har en forsvarer-posisjon, har hatt tidligere suksess, eller operer i et marked i vekst. Selskapet vi har studert i dybden kan hake av på alle disse kjennetegnene, kanskje med unntak av det siste. Likevel opplever lederne at de har et stort handlingsrom. Vår første konklusjon er derfor at ledernes opplevde handlingsrom er noe annet enn det teoretisk definerte handlingsrommet.

Et grunnleggende premiss i teorier om handlingsrom er at ledere som er oppmerksomme på ulike handlingsalternativer som er innenfor hva som er akseptabelt for aktører med makt til å påvirke prosesser, har flere muligheter til å velge hva den skal gjøre (Hambrick, 2007; Hambrick \& Finkelstein, 1987; Hutzschenreuter \& Kleindienst, 2013). Ifølge figur 1 over er da leders handlingsrom (LH) en funksjon av alternativene en leder er oppmerksom på (LO) og hva som er akseptabelt (AA). Dersom vi tenker at AA er konstant, vil LH øke dersom LO øker. Dette økte handlingsrommet kan da benyttes til å påvirke organisasjonen, og utøve ledelse i den retning ledelsen mener er best (Espedal \& Kvitastein, 2012). Dersom ledelsen er oppmerksom på få handlingsalternativer, vil den i større grad bli styrt av de som har makt til å definere hva som er akseptabelt.

En mangel med denne teorien er, slik vi ser det, at handlingsrommet er kvantitativt innrettet, en teller volum på oppmerksomhet: hvor mange alternativer er leder oppmerksom på? Hva dersom de handlingsalternativene som ledere er oppmerksomme på ikke (lenger) er nyttige for virksomhetens videre vekst og utvikling? I etablert teori om handlingsrom er dette i liten grad problematisert. Dersom vi spissformulerer det litt, spiller ikke innholdet så stor rolle: Bare lederne har mange nok alternativer å velge mellom, vil det gå greit. Menneskelige beslutninger preges imidlertid av begrenset rasjonalitet (Gigerenzer \& Selten, 2002; Tversky \& Kahneman, 1974, 1974, 1981). Ledere har begrenset kapasitet til å vurdere et stort antall alternativer (March \& Simon, 1958; Simon, 
1955). De har ikke kognitiv kapasitet til å velge det beste alternativet, men velger heller noe som er relativt kjent og virker trygt, basert på tidligere erfaringer. Vi vil derfor påstå at størrelsen (antall alternativer som vurderes) ikke nødvendigvis er det viktigste, men i hvilken grad alternativene som vurderes er strategisk relevante for virksomhetens utfordringer fremover.

\section{Hva er et strategisk relevant handlingsrom?}

Ifølge Hutzschenreuter og Kleindienst (2013) vil virksomheter innrettet mot utforsking øke sitt handlingsrom, mens de som er innrettet mot utnytting vil minske sitt handlingsrom. Dette er en tilnærming som sier at virksomheter bør være innrettet mot det ene, og ikke det andre. March (1991) hevder en slik ensidig tilnærming ikke er hensiktsmessig, da virksomheter må balansere effektiv utnytting med utforsking av nye muligheter.

Virksomhetene vi har studert opererer i et presset marked med svært små marginer. Vi ser av datamaterialet at effektiv drift er svært sentralt for dem, ikke bare nå, men også fremover. Selv om samtlige ti selskaper mener de er gode på dette nå, mener åtte av ti at de også må bli enda bedre på dette fremover. Det tilsier at effektiv drift er en pågående utfordring for selskapene.

Forskning på virksomheter i vekst viser at det over tid ikke er nok å bare ha en utforskende tilnærming og fokusere på mulighetene $\mathrm{i}$ markedet. De virksomhetene som klarer seg best over tid, er de som evner å både utforske muligheter og samtidig jobbe med kontinuerlige forbedringstiltak i daglig drift (Bastesen, 2015). De som glemmer det siste, og bare har rettet blikket mot markedsmulighetene, har større sannsynlighet for å tape i konkurransen på sikt (Bastesen, 2015). Dette står i kontrast til Hutzschenreuter \& Kleindienst (2013), som mener virksomheter bør være innrettet mot utforsking, og ikke utnytting.

Virksomhetene i vår studie er først og fremst innrettet mot utnytting, ikke utforsking, og vi stiller spørsmål ved hvorfor det er slik. Forbedring av måltall er enkelt kvantifiserbart og målbart, og det er ofte lettere å 
forholde seg til neste kvartalstall enn mer usikre utfordringer i fremtiden. Hutzschenreuter og Kleindienst (2013) peker på at en forutsetning for utforskende, strategisk tilnærming er slakk-ressurser i organisasjonen til å kunne utforske. Slike ressurser kan være alt fra finansielle ressurser til tid. Selskapene i denne studien mener de har slike ressurser, for eksempel fremhever lederne at de har avsatt godt med tid til å drive med ledelse i bred forstand. Likevel benyttes dette i liten grad til utforsking av strategiske signaler utenfra, eller til å utforske nye måter å organisere og drive virksomheten på fremover. De er mer innrettet mot stadige forbedringer av eksisterende drift. Alt i virksomhetene måles og veies på millimetereller sekundnivå. De er tydelig stolte når de kan fortelle at de har klart å knipe marginer slik og slik. Det er derfor ikke nok å ha slakk-ressurser de må også aktivt benyttes i utforsking av fremtidige trusler og muligheter (Penrose, 1959).

Tidspress kan påvirke evnen til tohendighet. Våre informanter informerer om at de har bra med tid til sine ledergjerninger. CEO i det ene selskapet mener de har lagt stor vekt på og lagt godt til rette for at lederne skal ha nok tid til å lede. Samtidig melder lederne om at det ofte er veldig hektisk, og at de da må sette alle kluter til for å få levert i tide til kundene. Vi får inntrykk av at lederne liker disse hektiske periodene. Det gir tilfredsstillelse og stolthet når lederne klarer å levere, selv om det ser håpløst og kaotisk ut. Det er disse historiene de gjerne trekker frem under intervjuene, og de blir gjerne fortalt også av andre ledere i andre intervjuer. Det indikerer at oppmerksomheten og «energien» i selskapene er mest innrettet mot å klare å levere og drifte, selv i hektiske perioder. Utfordringen for virksomheten er da at selv om lederne har tid til å rette oppmerksomheten mot både utforsking og utnytting, trenger de mekanismer som leder dem mot fokus på utforsking.

Videre ser vi at selskapenes kommunikasjonsstrukturer internt og eksternt heller ikke er designet for å fange opp og videreformidle informasjon «fra gulvet», eller fra eksterne aktører som kunder, konkurrenter og teknologileverandører. Strukturen i selskapet vi undersøkte mer i dybden viser en klar hierarkisk, nærmest maskinbyråkratisk, oppbygd virksomhet (Mintzberg, 1983). Virksomheten er inndelt i klart 
avgrensede, funksjonsbaserte avdelinger. Ansvaret er klart fordelt i en hierarkisk orden med under- og overordnede. Slike strukturer fører til avklarte ansvarsforhold med fokus på regler og prosedyrer, og er innrettet mot effektiv drift. De er ikke godt egnet til å få til samarbeid og informasjonsdeling på tvers (Anand \& Daft, 2007). Dersom slike strukturer fungerer godt for virksomheten, og de får utvikle seg over tid, kan virksomheten utvikle strukturell treghet, hvor det er vanskelig å få til radikale endringer. Hannan \& Freeman $(1977,1984)$ mener det er vanskelig å endre organisasjoner fordi de i utgangspunktet er innrettet mot stabilitet, og fordi organisasjonens medlemmer ofte vil yte motstand mot endringer. Tushman \& O’Reilly (1996) hevder at selskaper som har hatt suksess og fått utviklet seg over tid ikke bare utvikler en strukturell, men også en kulturell treghet i organisasjonen. Organisasjonsmedlemmene vil spørre seg hvorfor det er nødvendig å endre, ettersom de har hatt suksess slik de har drevet. Fokuset vil være å bli stadig bedre i det de er gode på, og organisasjonene er følgelig opptatt av inkrementelle forbedringer. Forfatterne hevder derfor at selskapene vil fortsatt ha suksess i stabile markeder, men vil feile dersom de møter store markedsendringer.

Basert på dataene vi har samlet og analysert, finner vi grunn til å anta at fortidens suksess, bygget på tydelige handlingsmønstre og overveiende fokus på utnytting, legger begrensinger på hvilke muligheter og alternativer ledelsen er klar over (LO). Ledelsen er her definert som toppledergruppen, altså de som har strategisk beslutningsmakt. Vi mener å se at ledelsen sammen konstruerer LO, altså at LO er sosialt konstruert basert på ledernes tolkning og forståelse av fortid som preger hva de ser som relevante alternativer i nåtid. Ulike ledergrupper kan derfor utvikle ulike forståelser av virkeligheten, altså virkeligheten slik de ser den.

Dersom vi ser de alternativer/muligheter ledelsen er klar over (LO) som sosialt konstruerte, må vi også se på hvilke faktorer som påvirker denne sosialt konstruerte forståelsen. Vi har drøftet hvordan historiske forhold, ikke minst tidligere suksess, er viktig for forståelsen av både fortid, nåtid og mulig fremtid. Teamlederne oppfatter sin rolle som klart operasjonell, ikke strategisk. Oppfattelsen er etablert i det sosiale samspillet hvor 
teamlederne får annerkjennelse for effektiv produksjon og oppnådde måltall, men ikke blir involvert i samme grad i utforskende prosesser. En utfordring er at heller ikke ledere på andre (høyere) nivåer ser ut til å bli involvert i utforskende prosesser, eller få sin anerkjennelse for innspill til nyskaping/utforskning.

Vår analyse av datamaterialet viser at leders oppmerksomhet (LO), altså de valgmuligheter leder er klar over, er sosialt konstruert i fellesskap i ledelsen. Ledelsens handlingsrom ( $\mathrm{LH}$ ) begrenses ved at alternativene våre informanter er klar over (LO) i stor grad bygges på gårdagens suksessoppskrift og mulighetene for å øke dagens effektivitet. Ifølge etablert teori om lederes handlingsrom, vil tidligere suksess redusere handlingsrommet. Det er bare selskaper i dynamiske omgivelser som fokuserer på utforsking og har en oppfinner-tilnærming, samtidig som de legger til rette for god informasjonsflyt og nok tid til å utforske, som vil ha et stort handlingsrom (Hutzschenreuter \& Kleindienst, 2013). Denne modellen fanger etter vår mening dermed ikke godt nok opp den situasjonen mange virksomheter står $\mathrm{i}$, nemlig at de har en suksessrik historie, de er i bransjer som har opplevd relativt lite dynamikk til nå, og de må fortsatt holde fokus på effektivitetsforbedringer og daglig drift for å henge med i konkurransen, samtidig som de må forberede seg på de store endringene som mest sannsynlig kommer. Vi finner at uten god kobling til fremtidige utfordringer og nødvendig utforsking av løsninger på disse utfordringene, mangler ledelsens handlingsrom strategisk relevans. I et strategisk relevant handlingsrom er alternativene leder er oppmerksom på og vurderer sammensatt av alternativer som både søker å videreføre effektiv drift, samtidig som man vurderer hvilke mulige scenarier som kan utspille seg i fremtiden, vurdering av hvordan en skal agere på disse, og eventuelle tiltak. Lederes strategisk relevante handlingsrom er illustrert i figur 2 som det området hvor både alternativene lederne er klar over (LO), alternativene det er aksept for blant interessentene med makt til å definere hva som er akseptabelt (AA) og de strategiske relevante alternativene som ledergruppen er oppmerksomme på (SRA) overlapper. Vi mener det er viktigere for virksomheter å identifisere i hvilken grad handlingsrommet er strategisk relevant, enn å måle hvor stort det er. 


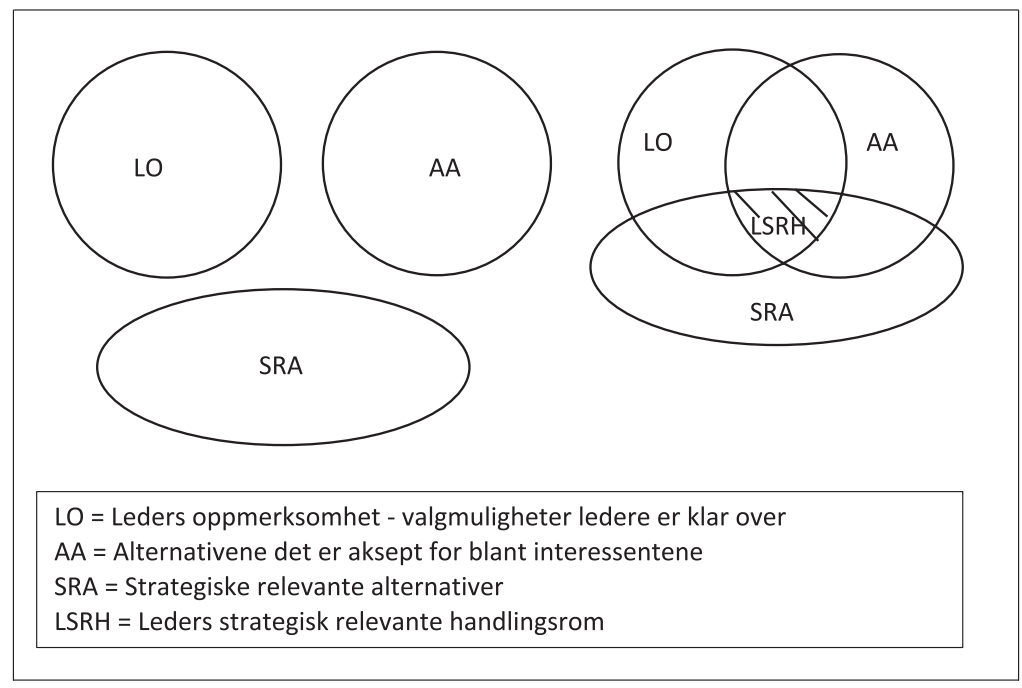

Figur 2 Strategisk relevant handlingsrom.

\section{Konkusjon og videre forskning}

Selskapene vi undersøker kan ikke slippe alt de har i hendene i dag og bare fokusere på utforsking av nye muligheter. Marginene i bransjen er svært små, og selskaper som vil lykkes, må opprettholde sin effektivitet. Samtidig kan de bli satt ut av spill i nær eller fjern fremtid dersom de ikke også er forberedt på store endringer. Dette er en bransje hvor det spås store endringer, og hvor noen virksomheter allerede har endret produksjonen radikalt (Carlin et al., 2015). Vi har i dette kapitet drøftet betydningen av stort opplevd handlingsrom $\mathrm{i}$ forhold til lederes evne og kapasitet til å håndtere fremtidige utfordringer. Videre har vi utvidet en modell utviklet av Hutchenreuter og Kleindienst (2013) gjennom å inkludere strategisk relevans som ny dimensjon i modellen. Avslutningsvis har vi diskutert oss frem til en definisjon av et nytt begrep: lederes strategisk relevante handlingsrom.

I fremtidige studier ser vi behov for å ikke bare bedre vår forståelse for hva et strategisk relevant handlingsrom er, men også utforske hvordan virksomheter kan legge til rette for et mer strategisk relevant handlingsrom i fremtiden. Tushman \& O’Reilly (1996) påpeker eksempelvis at for å sikre både utnytting og utforsking kan det være hensiktsmessig å opprette to ulike strukturer i samme organisasjon. Da kan én del ha 
fokus på stadig forbedring av det eksisterende, og en annen utforske nye muligheter for å sikre nødvendig inntjening og konkurransekraft også i fremtiden. Andre kjente teknikker for tohendighet er kontekstuell og sekvensiell tohendighet (Birkinshaw \& Gibson, 2004). Vi finner ingen slike ekstra-strukturer i selskapene i studien. Det betyr at vi ser strukturelle hindringer for ledernes strategisk relevante handlingsrom. Det kunne også vært interessant å studere andre strukturelle innretninger, samt hvordan ulike strategiske verktøy kan fremme eller hemme virksomheters evne til å legge til rette for strategisk relevant handlingsrom.

Andersen (2017) påpeker at det er behov for felles begreper og validerte mål for empiriske studier av lederes handlingsrom. Vi ser også behov for ytterligere operasjonalisering av vår modell for strategisk relevant handlingsrom for å kunne måle dette empirisk. Særlig gjelder dette dimensjonen strategisk relevante alternativer (SRA) ledergruppen er oppmerksom på. Vi har i dette kapitlet utviklet en konseptuell modell, men ser det som interessant å kunne utforske sammenhengene videre og utvikle modellen gjennom empiriske studier. For å gjøre det, trenger vi også teste og validere begrepet lederes strategiske handlingsrom.

\section{Referanser}

Anand, N. \& Daft, R. L. (2007). What is the right organization design? Organizational Dynamics, 36(4), 329-344. https://doi.org/10.1016/j.orgdyn.2007.06.001

Ancona, D. G., Goodman, P. S., Lawrence, B. S. \& Tushman, M. L. (2001). Time: A new research lens. Academy of Management Review, 26(4), 645-563. https://doi. org/10.5465/AMR.2001.5393903

Andersen, J. A. (2017). The concept of managerial discretion in corporate governance better off without it? Corporate Governance: The International Journal of Business in Society, 17(3), 574-587. https://doi.org/10.1108/CG-09-2016-0176

Bansal, P., Reinecke, J., Suddaby, R. \& Langley, A. (2019). Special issue of strategic organization "Temporal work: The strategic organization of time". Strategic Organization, 17(1), 145-149. https://doi.org/10.1177/1476127018824166

Bastesen, J. (2015). Rapid-growth firms in Norway: Characteristics of growth factors in benign and adverse environments (Doktoravhandling, Norges Handelshøyskole). Hentet fra https://hdl.handle.net/11250/2644911

Birkinshaw, J. \& Gibson, C. B. (2004). Building an ambidextrous organisation (SSRN Scholarly paper ID 1306922). Social Science Research Network. https://doi. org/10.2139/ssrn.1306922 
Braun, V. \& Clarke, V. (2006). Using thematic analysis in psychology. Qualitative Research in Psychology, 3(2), 77-101. https://doi.org/10.1191/1478088706qpo63oa

Carlin, M. S., Skjellaug, B., Nygaard, S., Vermesan, O., Svagård, I. S., Andreassen, T. W., ... Boysen, E. S. (2015). Effekter av teknologiske endringer på norsk næerings- og arbeidsliv (SINTEF Rapport A27222). Hentet fra http://hdl.handle. net/11250/2378812

Duncan, R. B. (1972). Characteristics of organizational environments and perceived environmental uncertainty. Administrative Science Quarterly, 17(3), 313-327. https://doi.org/10.2307/2392145

Duncan, R. (1979). What is the right organization structure? Decision tree analysis provides the answer. Organizational Dynamics, 7(3), 59-80. https://doi.org/ 10.1016/0090-2616(79)90027-5

Espedal, B. (2017). Understanding how balancing autonomy and power might occur in leading organizational change. European Management Journal, 35(2), 155-163. https://doi.org/10.1016/j.emj.2016.08.005

Espedal, B. \& Kvitastein, O. A. (2012). Rom for læring: Betydningen av handlingsrom for ledelse, Magma, 2012(8), 30-39. Hentet fra https://www.magma. no/rom-for-laring-betydningen-av-handlingsrom-for-ledelse

Finkelstein, S. \& Peteraf, M. A. (2007). Managerial activities: A missing link in managerial discretion theory. Strategic Organization, 5(3), 237-248. https://doi. org/10.1177/1476127007079975

Gigerenzer, G. \& Selten, R. (2002). Bounded rationality: The adaptive toolbox. Cambridge, MA: MIT Press.

Hambrick, D. C. (2007). Upper echelons theory: An update. Academy of Management Review, 32(2), 334-343. https://doi.org/10.5465/AMR.2007.24345254

Hambrick, D. C. \& Finkelstein, S. (1987). Managerial discrettion: A bridge between polar views of organizational outcomes. Research in Organizational Behavior, 9, 369 .

Hannan, M. T. \& Freeman, J. (1977). The population ecology of organizations. American Journal of Sociology, 82(5), 929-964. https://doi.org/10.1086/226424

Hannan, M. T. \& Freeman, J. (1984). Structural inertia and organizational change. American Sociological Review, 49(2), 149-164. https://doi.org/10.2307/2095567

Hernes, T., Simpson, B. \& Söderlund, J. (2013). Managing and temporality. Scandinavian Journal of Management, 29(1), 1-6. https://doi.org/10.1016/j. scaman.2012.11.008

Hutzschenreuter, T. \& Kleindienst, I. (2013). (How) Does discretion change over time? A contribution toward a dynamic view of managerial discretion. Scandinavian Journal of Management, 29(3), 264-281. https://doi.org/10.1016/j. scaman.2012.11.009

Klenke, K. (2008). Qualitative research in the study of leadership. Bingley: Emerald Group Publishing. 
LeBreton, J. M. \& Senter, J. L. (2008). Answers to 20 questions about interrater reliability and interrater agreement. Organizational Research Methods, 11(4), 815-852. https://doi.org/10.1177/1094428106296642

March, J. G. (1991). Exploration and exploitation in organizational learning. Organization Science, 2(1), 71-87. https://doi.org/10.1287/orsc.2.1.71

March, J. G., \& Simon, H. A. (1958). Organizations. New York: John Wiley \& Sons.

Miles, R. E., Snow, C. C., Meyer, A. D. \& Coleman, H. J. (1978). Organizational strategy, structure, and process. Academy of Management Review, 3(3), 546-562. https://doi.org/10.5465/amr.1978.4305755

Mintzberg, H. (1983). Structures in five designing effective organizations. New Jersey: Prentice-Hall.

Penrose, E. (1959). The theory of the growth of the firm (4. utg.). Oxford: Oxford University Press.

Perlow, L. A. (1999). The time famine: Toward a sociology of work time. Administrative Science Quarterly, 44(1), 57-81. https://doi.org/10.2307/2667031

Saunders, M. N. K., Lewis, P. \& Thornhill, A. (2019). Research methods for business students (8. utg., s. XXVI, 741). London: Pearson.

Shafritz, J. M., Ott, J. S. \& Jang, Y. S. (2015). Classics of organization theory. Boston, MA: Cengage Learning.

Simon, H. A. (1955). A behavioral model of rational choice. The Quarterly Journal of Economics, 69(1), 99-118. https://doi.org/10.2307/1884852

Staudenmayer, N., Tyre, M. \& Perlow, L. (2002). Time to change: Temporal shifts as enablers of organizational change. Organization Science, 13(5), 583-597. https:// doi.org/10.1287/orsc.13.5.583.7813

Stewart, R. (1982). A model for understanding managerial jobs and behavior. Academy of Management Review, 7(1), 7-13. https://doi.org/10.5465/ amr.1982.4285424

Tushman, M. L. \& Murmann, J. P. (1998). Dominant designs, technology cycles, and organization outcomes. Academy of Management Proceedings, 1998(1), A1-A33. https://doi.org/10.5465/apbpp.1998.27643428

Tushman, M. L. \& O’Reilly III, C. A. (1996). Ambidextrous organizations: Managing evolutionary and revolutionary change. California Management Review, 38(4), 8-30. https://doi.org/10.2307/41165852

Tversky, A. \& Kahneman, D. (1974). Judgment under uncertainty: Heuristics and biases. Science, 185(4157), 1124-1131. https://doi.org/10.1126/science.185.4157.1124

Tversky, A. \& Kahneman, D. (1981). The framing of decisions and the psychology of choice. Science, 211(4481), 453-458. https://doi.org/10.1126/science.7455683

Yin, R. (2018). Case study research and applications: Design and methods (6. utg.). London: Sage. 


\title{
KAPITTEL 5
}

\section{Oppdragsbasert ledelse: Ledelse og styring gjennom intensjoner}

\author{
Andreas Thon og Thea Renate Berg \\ Høyskolen Kristiania
}

\begin{abstract}
In recent decades we have seen examples of how some organizations lack the capabilities necessary to maneuver in times of uncertain, rapidly changing and unstable environments. During the Covid-19 pandemic, the importance of the ability to make quick responses to changing environments became evident. In a military context, dealing with such unstable circumstances has been commonplace for some hundred years. Based on this observation, we seek to answer the following questions: What can we learn from the military concept mission command that can have an impact on leadership in civilian organizations? In order to answer these questions, we first discuss and define the concept of mission command. Using document analysis and participatory observation, we define mission command as a leadership concept and examine examples of mission command leadership styles in civilian organizations. Furthermore, we discuss whether classic leadership theory includes important characteristics of mission command. Main findings include what civilian organizations can learn from how military units have maneuvered in uncertain and complex environments, and secondly, how mission command is based on an understanding of how leadership is an organizational capability. This article focuses on the leader as part of an organizational system, and not the "heroic perspective" of the leader in person. We conclude by suggesting developing intention-based leadership as a theoretical concept for civilian use of the military leadership philosophy.
\end{abstract}

Keywords: mission command, commander's intent, oppdragsbasert ledelse, intensjonsbasert ledelse, distribuert ledelse, post-heroisk ledelse

Sitering av denne artikkelen: Thon, A. \& Berg, T. R. (2020). Oppdragsbasert ledelse: Ledelse og styring gjennom intensjoner. I J. Bastesen, B. K. Lange, H. E. Næss \& A. N. Thon (Red.), Ledelse av mennesker $i$ det nye arbeidslivet (Kap. 5, s. 135-161). Oslo: Cappelen Damm Akademisk. https://doi.org/10.23865/ noasp.118.ch5

Lisens: CC-BY 4.0. 


\section{Introduksjon}

Oppdragsbasert ledelse har utspring i behovet for et ledelseskonsept i militær sammenheng. Militære avdelinger har i all tid måttet håndtere et situasjonsbilde preget av usikkerhet, uforutsigbarhet og høy endringstakt. Beslutningssituasjoner kan ha begrenset tid, og situasjoner med mangel på offensive initiativ kan ha betydning for liv og død. Oppdragsbasert ledelse i militær sammenheng bygger på en felles oppfatning av sjefens intensjon som strategisk utgangspunkt for operativ ledelse og styring i alle ledd i organisasjonen. Hvordan oppdraget skal løses må til enhver tid delegeres til «the man on the ground», det vil si den som står tettest på situasjonen. I militær sammenheng måtte man tidlig lære seg å håndtere kompleksitet og usikkerhet. I løpet av 200o-tallet har kaosog kompleksitetstenkning fått en større utbredelse, også i samfunnet for øvrig. I organisasjonssammenheng har man måttet endre fokus fra i hovedsak å være opptatt av indre effektivitet, til å ta hensyn til et situasjonsbilde hvor virksomheten i stor grad også påvirkes av omgivelser og ytre faktorer som globalisering, digitalisering, automatisering, grønt skifte, politisk ustabilitet og pandemi. Dette påvirker hvordan sivile ledere $\mathrm{i}$ virksomheter $\mathrm{i}$ vår tid må oppfatte og håndtere uoversiktlige og skiftende omgivelser.

Dette kapittelet søker med det å gi svar på følgende spørsmål:

Hva kan vi loere av det militore ledelseskonseptet oppdragsbasert ledelse som kan ha betydning for ledelse i sivile virksomheter $i$ vår tid?

Vi går først gjennom en historisk og moderne forståelse av hva oppdragsbasert ledelse er, slik det er redegjort for i militære doktriner i det norske forsvaret og i sentrale NATO-land. Vi bruker dokumentanalyser og deltakende observasjon for å undersøke to eksempler fra henholdsvis logistikkvirksomhet og covid-19/pandemisituasjonens påvirkning i offentlig sektor. Disse settes i sammenheng med det vi tolker som oppdragsbasert ledelsesfilosofi fra sivil praksis i vår tid. Videre sammenligner og diskuterer vi hvorvidt klassisk ledelsesteori favner viktige kjennetegn ved oppdragsbasert ledelse, før vi avslutningsvis foreslår noen brede og fremtidsrettede perspektiv. 


\section{Metode}

Vår studie benytter kvalitative metoder, da disse gir oss mulighet til å utforske fenomener i virkeligheten på en utdypende og grundig måte (Yin, 2018). Dette har vi gjort ved dokumentanalyser og deltakende observasjon.

For å redegjøre for oppdragsbasert ledelse som militært ledelseskonsept er det gjennomført en analyse av relevante dokumenter fra militære kilder. Fordelen med å anvende dokumentanalyse er at man kan skaffe seg informasjon om saksforhold som er nedtegnet på bestemte steder og tider, og til ulike formål (Tjora, 2017, s. 182). Oppdragsbasert ledelse i militær sammenheng er godt dokumentert gjennom beskrivelser av militær teori gjennom 200 år. Dagens tenkning og beskrivelse av hvordan oppdragsbasert ledelse skal forstås som ledelseskonsept, er utredet og beskrevet i militære doktriner utviklet gjennom de seneste 40 år. Denne studien bygger på ulike militære doktriner: Forsvarets grunnsyn på ledelse (Forsvaret, 2012); Forsvarets fellesoperative doktrine (Forsvare,t 2014, 2019); The British Army Doctrine Publication Land Operations (ADP, 2017); US Army Doctrine Publication (APD, 2012, 2019). Dokumentstudiene har gjort det mulig å redegjøre for hvordan oppdragsbasert ledelse forstås, tolkes og anvendes i vår tid.

Videre bygger studien på eksisterende ledelseslitteratur. Det er ikke gjennomført klassisk testing av teori, men i stedet søkt å utforske og få en rikere forståelse for hvordan ulike aspekter ved disse teoriene kan forstås og fortolkes. Dette er gjort med hovedvekt på Arnulf, 2020; Gardner et al., 2020; Klemsdal, 2018; Parry og Bryman, 2016.

Der dokumentstudier er kilder om hva som har skjedd, er deltakende observasjon innsamling av data i realtid. Observasjoner tilhører også fenomenologien; studiet av fenomener og hvordan de fremtrer for oss fra et førstepersons-perspektiv (Schiermer, 2013). Vi kan si at de to metodene utfyller og kompletterer hverandre. Katrine Fangen (2004, s. 140) sier om deltakende observasjon:

Som deltagende observatør er du fullt engasjert i å erfare feltet samtidig som du forsøker å forstå det gjennom observasjoner og samtaler med deltakerne om det som skjer. Du har gode muligheter til å prøve ut og diskutere dine fortolkninger 
av det som skjer med deltakerne. Kunnskapen blir derfor til i samarbeid mel-

lom deltakerne og deg.

I lys av dette har vi benyttet observasjon for å undersøke hvorvidt oppdragsbasert ledelse kan ha betydning i ledelse i sivile virksomheter i vår tid. Observasjoner fremheves som en lite benyttet metode i de tradisjonelle studiene av ledelse og organisasjon (Saunders, Lewis \& Thornhill, 2019), I sosialantropologien er deltagende observasjon derimot en kjent og mye brukt metode. Lange feltarbeid gir innsikt som ikke kan erververs ved andre metoder - det gir svar på spørsmål vi ikke stilte da vi startet. Dermed kan man forstå og forklare årsaker med tykke beskrivelser (thick descriptions), heller enn tynne beskrivelser (thin descriptions), som kun gjengir det som skjer eller det man har lest uten å sette det inn i en større sammenheng. Tykke beskrivelser gir dermed forskere bedre grunnlag for å analysere datamaterialet kontekstuelt (Danielsen, 2018, s. 23). Watson (2011) argumenterer eksempelvis for at vi må forstå menneskers adferd og det sosiale samspillet, for å forstå organisasjoner og deres identitet. Med blikk for nettopp slike sosiale, menneskelige og praksisrelaterte perspektiver mener vi deltagende observasjon er svært hensiktsmessig i sammenheng med vår problemstilling.

Observasjonene er gjennomført todelt. Første del av observasjoner er gjennomført i 2018 til 2020, hvor vi deltok på ledersamlinger i 10 ulike logistikkselskap. Samlingene ble gjennomført som møter med ledergrupper (administrerende direktør, driftsdirektør, markedsdirektør, økonomisjef), og i møter med utvidet ledergruppe (selskapsledelse, mellomledelse og teamledelse i drift), hvor lederne har reflektert over egen organisasjons interne styrker. Til sammen observerte vi i denne perioden rundt 250 ledere. I et av selskapene gjennomførte vi et feltarbeid. Over 2 dager fulgte vi selskapets drift ved å observere og snakke med 25 teamledere og medarbeidere i produksjon. Vi gjennomførte også to møter med utvidet ledergruppe for å høre deres refleksjoner om ulike tema, som ledelse av arbeid og ledelse av mennesker. I etterkant av dette har vi fulgt to grupper av teamledere i refleksjonsmøter annenhver måned $\mathrm{i}$ et halvt år, hvor ledelse av drift sto på agendaen. Alle informantene var informert om studien, og ga sitt samtykke til observasjonene. 
Den andre feltperioden ble gjennomført som observasjoner av dagsaktuelle eksempler knyttet til håndteringen av pandemiutbruddet av covid19 og den påfølgende nedstengingen av det norske samfunnet. Vi fulgte nyhetssendinger og leste intervjuer i perioden 10. mars til 8. april 2020, og noterte underveis uttalelser som kan gi en innsikt i hvordan det usikre og uoversiktlige situasjonsbildet i perioden påvirket ny forståelse og utøvelse av lederrollen på flere nivå.

\section{Oppdragsbasert ledelse i et historisk perspektiv}

Oppdragsbasert ledelse har lange tradisjoner i militær sammenheng. For om lag 200 år siden utviklet den prøyssiske offiseren Karl von Clausewitz militære teorier som beskrev behovet for å se organisasjonen som et strategisk plannivå og et taktisk utøvende nivå (APD, 2019). Knappe hundre år senere ble Helmuth von Moltke, sjef for den tyske generalstaben ved utbruddet av første verdenskrig, en av de viktigste bidragsyterne til utvikling av tenkning om ledelse og styring i tyske militære avdelinger (Tøllefsen, 2019). Mot slutten av 180o-tallet innførte han Auftragstaktik (oppdragstaktikk eller oppdragsbasert ledelse) som konsept og ledelsesfilosofi i den tyske hæren (APD, 2019). General Moltke forstod at detaljerte operasjonsplaner hadde begrenset verdi i møte med den bevegelige striden. Han la vekt på at den strategiske, overordnede ordren skulle være retningsgivende for de løpende beslutninger som ble fattet av ledere i fremste linje på taktisk nivå, basert på utvikling i situasjonsbildet (APD, 2019). Moltke var opptatt av å utvikle en organisasjon som evnet å omsette strategiske planer i uforutsigbare omgivelser preget av høyt endringstempo. Dette forutsatte at ledere på alle nivå hadde felles forståelse av og tilslutning til oppgaven, og at taktiske beslutningsprosesser og utførelse var preget av delegert autonomi (Bungay, 2010).

Hvis vi ser rent militærhistorisk på andre verdenskrig, så var manøverkrigføring og oppdragsbasert ledelse, eller Auftragstaktik, et grunnleggende konsept for tyske militær avdelinger (Zetterling, 2003; Grint, 2014). Den tyske militærmakten var underlegen med tanke på materiell og antall soldater både på vest- og østfronten. Vesentlig for den hurtige tyske fremmarsjen i begynnelsen av andre verdenskrig, var de operative 
ledernes evne til å finne svake punkter i fiendens forsvar (situasjonsforståelse), kombinert med handlingsrom, initiativ, beslutningsvilje, mobilitet og tempo. Der de tyske styrkene baserte seg på mobilitet og lokalt initiativ, var de allierte styrkene statisk i organisering av striden, topdown styrt med lange beslutningslinjer, og beslutninger fattet på høyere nivå uten oversikt over endringer i situasjonsbilde. Allierte offiserer i fremste linje hadde i mindre grad mulighet til å fatte beslutninger basert på stridens gang.

Oppdragsbasert ledelse som ledelseskonsept er de siste 40-50 årene valgt og videreutviklet av de fleste lands forsvarsstyrker (Maciejewski, 2019; Grant, 2017). Russernes opplevelse av kompleksitet i Afghanistan, amerikanernes erfaringer fra Midtøsten, britenes erfaringer fra Falklandsøyene og det norske forsvarets erfaringer fra både Balkan og Midtøsten har gjort at sjefer på strategisk og operasjonelt nivå i kommandokjeden erkjente at de ikke kunne styre operasjoner på noe annet enn intensjoner.

\section{Kjennetegn ved oppdragsbasert ledelse som ledelseskonsept i militær sammenheng i dag}

En intensjon er sjefens hensikt med det oppdraget som skal løses; hva sjefen vil med oppdraget og i hvilken hensikt oppdraget skal gjennomføres. Den høyere intensjonen kommuniseres fra strategisk nivå gjennom alle ledd og helt ut i organisasjonen. Felles oppfatning og forståelse av intensjonen styrer og forener handlinger i felles retning (Yardley \& Kabadase, 2007). Nye doktriner for ledelse og styring av militære avdelinger og operasjoner har gjort seg gjeldende. Der det tidligere ble benyttet begreper som Command and Control, er det nå fokus på Mission Command som ledelsesfilosofi og utgangspunkt for kultur i organisasjonen (APD, 2019). I dette avsnittet presenteres kjennetegn ved oppdragsbasert- og intensjonsbasert ledelse i militær sammenheng.

\section{Forsvarets fellesoperative doktrine (2014 og 2019)}

Forsvarets fellesoperative doktrine sier om operativ ledelse at kommando og kontroll i Forsvaret er basert på oppdragsbasert ledelse som 
ledelsesfilosofi (Forsvaret, 2019), og at dette gjelder både i fred og krig. Militært lederskap dimensjoneres for en kompleks virkelighet som er vanskelig å forutsi og forstå (Forsvaret, 2012). Usikkerheten og uforutsigbarheten knyttet til omgivelsene er det sentrale utgangspunktet for hvorfor oppdragsbasert ledelse, og ledelse og styring gjennom intensjoner, har vokst frem som konsept for ledelse og organisasjonsmodell i militær sammenheng.

Overordnet handler oppdragsbasert ledelse om å benytte kreativiteten i hele organisasjonen, hvor vellykket utførelse av oppgaver kommer som et resultat av at underordnede ledere i alle ledd tar målrettede initiativ basert på sjefens intensjon (Forsvaret, 2012). Sjefens intensjon er styrende for de beslutninger og handlinger som gjennomføres nedover i organisasjonen. Det forventes at ledere i alle ledd tar disiplinerte initiativ som bringer organisasjonen i retning av overordnede målsettinger. Når intensjonen er felles oppfattet i alle ledd i organisasjonen, skapes det rom for desentralisert autoritet og beslutninger ute i linjen. Desentralisert autoritet gir ledere på alle nivå stor grad av handlingsrom. Den felles oppfattede intensjonen gir rammer som koordinerer aktivitet i felles retning. Sjefens intensjon blir med det organisasjonens styringsverktøy, samtidig som det forventes at alle ledere utøver et aktivt lederskap basert på lokal situasjonsforståelse.

I oppdragsbasert ledelse som ledelsesfilosofi og kultur legges det vekt på at: «Utstrakt bruk av detaljstyring er temporeduserende, undergraver tillitsrelasjonene i organisasjonen, og ødelegger viljen til å ta ansvar og å handle selvstendig på eget initiativ» (Forsvaret, 2019, s. 179). Samtidig vil enkelte oppgaver fortsatt måtte løses innenfor sterkere grad av kontroll gjennom direkte styring, regler og prosedyrebeskrivelser. Desentralisert ledelse begrenser ikke øverste sjefs mulighet til å ta direkte ledelse når situasjonen krever det.

\section{Forsvarssjefens grunnsyn på ledelse}

Forsvarssjefens grunnsyn på ledelse (Forsvaret, 2012) er en bevisstgjøring av hvilke prinsipper og verdier som ligger til grunn for gjennomføring av oppdragsbasert ledelse. 
Oppdragsløsning i en kompleks kontekst krever en klar intensjon, god situasjonsforståelse og desentralisert håndtering. Utgangspunktet knyttet til kompleksiteten i omgivelsene er førende for behovet for desentralisert ledelse basert på sjefens intensjoner. Lederens rolle er utfordrende, fordi alle må håndtere usikkerhet og mestre tilpasning til skiftende situasjoner. I overordnet tenkning om ledelse er det avgjørende at det skapes en felles forståelse og referanserammer for hva godt lederskap er, og et felles tankesett rundt hvordan ledelse utøves. Lederskapet preges av lederens evne til å bygge relasjoner, skape tillit og samtidig opprettholde kontroll. I lederens rolle vektlegges kommunikasjon av overordnete intensjoner og mål helt ut, slik at alle i organisasjonen utøver sine oppgaver basert på en felles målforståelse. Videre legges det vekt på kulturutvikling i organisasjonen. Gjennom læringsprosesser, teambuilding og relasjonsutvikling bygges det over tid en oppdragsbasert organisasjonskultur som oppfordrer til å ta initiativ, utnytte kreativitet i de menneskelige ressursene, fremme fleksibilitet og evne til handling (se figur 1).

Tabell 1 Forutsetninger for oppdragsbasert ledelse (Forsvaret, 2012)

\begin{tabular}{|l|l|}
\hline Organisatoriske Forutsetninger & Individuelle Forutsetninger \\
\hline Teamledelse & Rollemodell \\
- medansvar og involvering & $\begin{array}{l}\text { - forbilde } \\
\text { - verdigrunnlag }\end{array}$ \\
\hline Oppdragsbasert organisasjonskultur & Balansert lederadferd \\
- samhold & - oppdragsfokus \\
- tillit & - samspill \\
- forpliktelse & - utvikling \\
- holdninger og etikk & \\
- omstillingsevne & \\
- situasjonsforståelse & \\
- faglig dyktighet & \\
\hline
\end{tabular}

\section{US Army: Mission Command}

Den amerikanske hæren introduserte Mission Command (oppdragsbasert ledelse) som ledelseskonsept i 2003 (Martin, 2017). I Army Doctrine Publication No. 6-o (APD, 2019, s. 1-3) defineres begrepet som følger: «Mission command is the Army's approach to command and control that empowers 
subordinate decision making and decentralized execution appropriate to the situation.» Utgangspunktet for den amerikanske hærens tilnærming til oppdragsbasert ledelse, er at organisasjonen opererer i omgivelser preget av kaos og usikkerhet. Planer vil måtte justeres basert på endringer i situasjonsbildet, og mangel på informasjon gjør beslutningsprosesser utfordrende. Underordnede ledere er derfor best i stand til å fatte beslutninger basert på kunnskap om situasjonen for å oppnå sjefens intensjoner; selv når disse leder til handlinger utenom den opprinnelige planen. Oppdragsbasert ledelse beskrives både som utgangspunkt for systemtenkning og som ledelsesfilosofi. Mission Command gir slik det beskrives en tilleggsdimensjon til Command and Control, ved å tydeliggjøre sjefens intensjon som styrende for gjennomføring av oppdrag, og gjennom at autoritet delegeres til undergitte ledere, med en forventning om disiplinerte initiativ. Forutsetninger for å lykkes med oppdragsbasert ledelse bygger på felles forståelse og forpliktelse til oppdraget, samt kompetente ledere og undergitte som settes i stand til å løse oppgaver. For å utnytte muligheter innenfor rammen av sjefens intensjon, må organisasjonen preges av gjensidig tillit på tvers av nivåer og funksjoner, team- og relasjonsutvikling, samt aksept for at det tas risiko på alle nivå. Hensikt med oppdraget og ønsket sluttsituasjon gis gjennom oppdragsordrer med et så lavt detaljnivå at organisasjonens medlemmer har størst mulig handlefrihet til å løse situasjonen. Oppdragsordren gir nødvendige rammer og reguleringer for fortolkninger, handlinger og atferd.

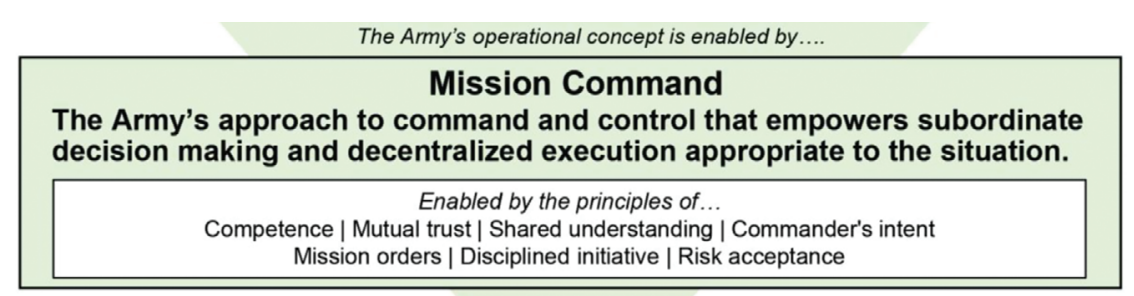

Command and control is fundamental to all operations...

Command and Control

Command and control is the exercise of authority and direction by a properly designated commander over assigned and attached forces in the accomplishment of a mission.

\begin{tabular}{|l|l|}
\hline Elements of Command & Elements of Control \\
- Ruthority & - Direction \\
- Desponsibility & - Feedback \\
- Leadership & - Information \\
- Communication
\end{tabular}

Figur 1 Logic map (APD, 2019, Introduction). 


\section{The British Army: Land Operations}

Først etter Falklandskrigen i 1982 utviklet den britiske hæren konsepter for oppdragsbasert ledelse. Med lange kommandolinjer og begrensede ressurser erfarte britene at soldater på bakken ventet på ordre, selv når det medførte tap av menneskeliv (Maciejewski, 2019). Etter Falklandskrigen innførte British Army desentraliserte ledelsesformer tilpasset behovet for raske beslutninger. I den britiske hærens operative doktrine, Army Doctrine Publication Land Operations (ADP, 2017), redegjøres det for at britiske hærstyrker historisk har basert sine ledelseskonsept rundt sentralisert kontroll. Sentralisert kontroll innebærer en ordrestyrt operasjonsledelse, hvor det ikke tas tilstrekkelig hensyn til at omgivelsene er dynamiske. Ledere på høyere nivå har ansvar for å definere overordnede planverk, men kan vanskelig treffe riktige beslutninger til riktig tid på et taktisk nivå. I ADP (2017) beskrives Mission Command og Manoeuvrist Approach som grunnleggende ideer i operativ ledelse. Mission Command defineres som «the clear expression of intent by commanders, and the freedom subordinates have to act to achieve that intent» (ADP, 2017, 6-1).

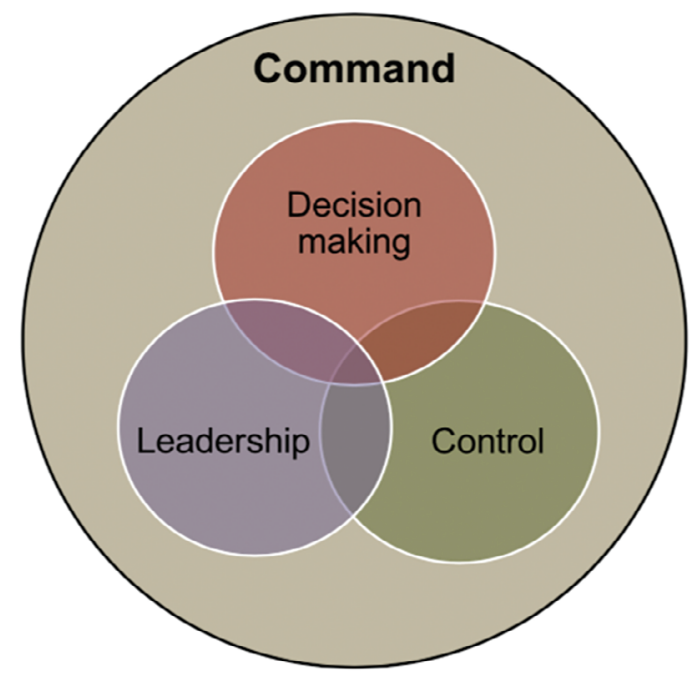

Figur 2 Functions of Command (ADP/LO, 2017, 6-2).

Ledelse utøves gjennom delegert autoritet som gir undergitte ledere handlingsrom til å fatte beslutninger og gjennomføre disse. Med delegert 
autoritet følger ansvar for, og forventning om, å fatte selvstendige beslutninger og ta aktive initiativ. Militær ledelse på alle nivå er et samspill mellom å utøve et motiverende, delegerende og retningsgivende lederskap, fatte beslutninger på lavest mulig nivå, samt utøve nødvendig koordinering, styring og kontroll.

Oppdragsbasert ledelse bygger på et absolutt overordnet prinsipp: «the absolute responsibility to act to achieve the superior commander's intent» (ADP, 2017, 6-5). Øvrige prinsipper for oppdragsbasert ledelse som konsept er:

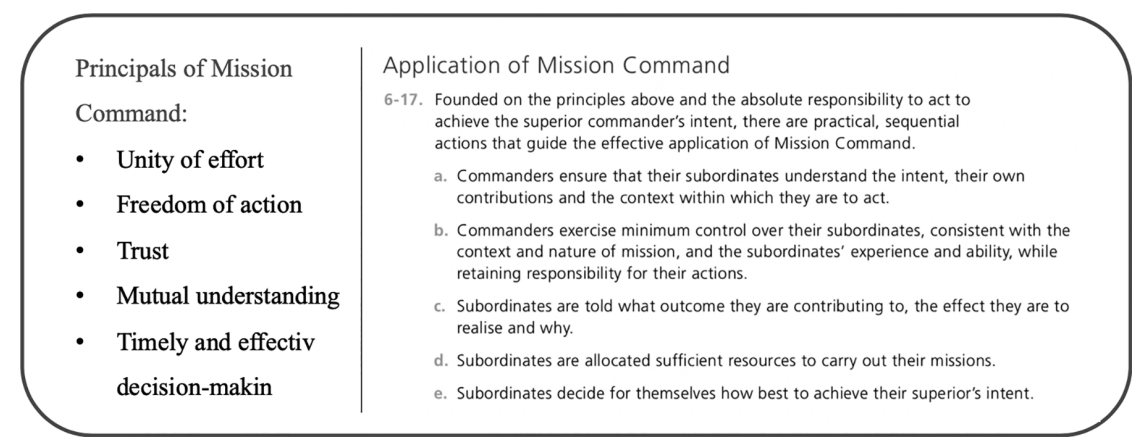

Figur 3 Principles of Mission Command (ADP, 2019, 6-5, 6-7).

\section{Oppdragsbasert ledelse oppsummert}

Oppdragsbasert ledelse tar utgangspunkt i øverste leders tydelige uttalte intensjon. Intensjonen må være felles oppfattet, forstått og akseptert i hele linjen; det vil si kollektivt internalisert blant alle medlemmene i organisasjonen. Internalisering handler om både kognitiv og praktisk forståelse, samt følelsesmessig forpliktelse. Beslutninger i fremste linje i organisasjonen baseres på en felles forståelse av intensjoner uttrykt som hensikt og effekt, altså den definerte strategiske målsetningen, eller ønsket sluttsituasjon. Intensjonen gir retningslinjer og mulighet for fleksibilitet i usikre og dynamiske omgivelser. Ved behov for mer overordnet styring gis det operasjonsordrer, eller rules of engagement. Overordnede regler og bestemmelser må ha et så lavt detaljnivå som mulig. Gjennom oppdragsbasert ledelse oppfordres individene til å ta selvstendige og målrettede initiativ basert på situasjonsforståelse, 
samtidig som organisasjonen utvikler evne til å operere med enhetlig innsats.

Oppdragsbasert ledelse må ikke misforstås, slik at det betyr at alt ansvar og myndighet delegeres til autonome ledere eller team. Sjefens rolle, ansvar og autoritet delegeres ikke, men sjefen deler ledelse i linjen. Thomas Williams (2016) ved US Army War College sier følgende om oppdragsbasert ledelse:

It represents a culture where mutual trust and the concomitant willingness to accept prudent risk govern. It comes with an expectation that commanders respect their subordinates' judgment and issue orders that focus on intent rather than tasks. [...] Mission command leadership [...] is not an act, a process, or a position. Mission command leadership is an evolving social perception concerning authority, relationships, shared understanding, purpose, trust, risk, and environment.

Kjennetegn ved oppdragsbasert ledelse som militært konsept og ledelsesfilosofi oppsummert fra militære doktriner:

Tabell 1 Kjennetegn ved oppdragsbasert ledelse

\begin{tabular}{|c|c|c|}
\hline \multicolumn{3}{|c|}{$\begin{array}{l}\text { Omgivelser preges av } \\
\text { Stor endringstakt, høyt tempo, kompleksitet, uforutsigbarhet, usikkerhet }\end{array}$} \\
\hline $\begin{array}{l}\text { Oppdragsbasert ledelse } \\
\text { Sjefens intensjon } \\
\text { (strategisk nivå) - tydelig } \\
\text { formulert hensikt, retning } \\
\text { og sluttsituasjon, oppfattet } \\
\text { kollektivt av alle } \\
\text { System for kommando og } \\
\text { kontroll - avklarte rammer, } \\
\text { operasjons- ordre, rules of } \\
\text { engagement } \\
\text { Delegert autoritet (taktisk } \\
\text { nivå) - handlingsrom } \\
\text { innenfor sjefens intensjon } \\
\text { og gitte rammer } \\
\text { Målrettede initiativ - } \\
\text { linjeleders beslutninger, } \\
\text { basert på lokal innsikt og } \\
\text { endringer i situasjonsbilde }\end{array}$ & $\begin{array}{l}\text { Organisatoriske forutsetninger } \\
\text { Organisasjonskultur - felles } \\
\text { oppfattet verdigrunnlag, } \\
\text { holdninger, medansvar, forpliktelse } \\
\text { Støttende ledelse - tilføre } \\
\text { ressurser nødvendig for oppgaven } \\
\text { Gjensidig tillit } \\
\text { Risikohåndtering - aksept for } \\
\text { risiko og feil } \\
\text { Lederutvikling - oppdragsbasert } \\
\text { ledelse, lederskap } \\
\text { Teamutvikling - relasjonsutvikling, } \\
\text { samhandling } \\
\text { Kommunikasjon - } \\
\text { informasjonsdeling og feedback } \\
\text { Læring - sosiale og kognitive } \\
\text { læringsprosesser }\end{array}$ & $\begin{array}{l}\text { Individuelle forutsetninger } \\
\text { Kompetanseutvikling - } \\
\text { funksjonell ekspertise, } \\
\text { situasjonsforståelse, trening } \\
\text { Problemløsende tenkning } \\
\text { Sosial trygghet - mot til å } \\
\text { beslutte og ta risiko } \\
\text { Disiplinerte initiativ - evne } \\
\text { og vilje til å handle i henhold } \\
\text { til sjefens intensjon }\end{array}$ \\
\hline
\end{tabular}




\section{Eksempler på oppdragsbasert ledelsesfilosofi fra sivil praksis i vår tid}

Clausewitz' og Moltkes tanker om at overordnet strategisk nivå skulle være retningsgivende for taktiske beslutninger i fremste linje, basert på utvikling i striden og dermed endret situasjonsbilde, viser hvordan man i militær sammenheng tidlig måtte lære seg å håndtere kompleksitet og usikkerhet. De siste tiårene har kaos- og kompleksitetstenkning fått større utbredelse også i sivil sammenheng. Raske skifter i omgivelsene synliggjør behovet for målrettede initiativ og høyere tempo i beslutninger også i sivil sammenheng. I det følgende beskrives to eksempler på hvordan usikkerhet og uforutsigbarhet i omgivelsene fremmer betydningen av at overordnede intensjoner omsettes i målrettede handlinger basert på lokal situasjonsforståelse i nåtid.

\section{Oppdragsbasert ledelse i logistikk}

Logistikktjenester omfatter en kompleks drift bestående av inngående varestrøm fra leverandører, sammenstilling av varer basert på bestillinger fra kunder, og distribusjon gjennom utgående transport. Konkurransefortrinn i logistikktjenesten baseres på effektiv drift, lave kostnader og høy grad av kundetilfredshet. Kvalitet og effektivitet i verdikjeden utfordres daglig av uforutsigbare hendelser i omgivelsene som påvirker en finjustert verdikjede. Det kan være utfordringer med leveranser fra leverandører, distribusjon som hindres av vær og føreforhold, etterbestillinger kunden opplever som sentral for kundetilfredshet hos sluttkunden, osv. Slike hendelser oppstår uten forvarsel, forstyrrer planlagt varestrøm og distribusjon, og utfordrer logistikktjenestens mulighet til å levere til kunden.

Eksempelet i denne casen er basert på et prosjekt med tema målstyrt ledelse og verdikjedeutvikling i 10 logistikkselskap med 150 til 350 ansatte tilknyttet detaljhandel og kjededrift. Gjennom deltagende observasjon i ledersamlinger på ledergruppenivå, i utvidet ledergruppe, samt i møter med grupper av teamledere, var det mulig å følge med på hvordan overordnede mål og ambisjoner ble kommunisert, oppfattet, forstått og gjennomført i produksjonsleddet. 
De strategiske målsettingene varierer i de ulike selskapene. Felles for alle selskapene er imidlertid en tydelig målsetting og et høyt ambisjonsnivå knyttet til kundens tilfredshet med effektiv og nøyaktig leveranse. I møter med ledergrupper og utvidete ledergrupper har vi stilt et åpent spørsmål om ledernes opplevelse av eget selskaps styrker. En opplevd styrke utpeker seg spesielt på tvers av selskapene: «Evne til å levere i daglig drift». I alle de 10 selskapene defineres dette som en fremtredende kvalitet og et sentralt fokus i organisasjonen.

I diskusjonene hvor lederne utdyper egne synspunkt, fremgår det at lederne oppfatter at de er spesielt gode til å håndtere uforutsette hendelser i daglig drift og finne ad-hoc løsninger, slik at kunden får levering av varene som er bestilt. De oppfatter å ha et tydelig kundefokus i hele verdikjeden, og at dette er noe alle på tvers av nivå og funksjon er opptatt av og er stolte av.

I diskusjoner i selskapene om hva teamledere oppfatter som sine hovedoppgaver, fremkommer det entydig på tvers av alle selskapene at «å levere det kunden har bestilt, til riktig tid, så effektivt som mulig» er det sentrale oppdraget for teamet. Teamleder ser på sin avdelings funksjon som en del av en helhetlig varestrøm og verdikjede i selskapet. Dette fremkommer også tydelig i selskapet der vi har gjort feltarbeid, gjennom samtaler med teamledere og medarbeidere i hele verdikjeden. Denne delen av målbildet fremstår som internalisert, og med medarbeidere som føler en sterk forpliktelse overfor oppgaven. Vi noterte utsagn som:

- Vi er ikke ferdig før alle er ferdig

- Min viktigste oppgave er å sørge for at transporten kommer av gårde til riktig tid

- Hvis vi skal håndtere et økt volum så ser vi jo det at vi ikke nødvendigvis trenger å jobbe hardere, men vi trenger å jobbe smartere

- Vår målsetting er at vi til enhver tid skal kunne ta imot sjåfører, at det aldri skal være noen ventetid. Vi føler at vi løser oppdraget vårt hver dag ved å fylle den ambisjonen

Teamlederne oppfatter at de må forholde seg til et definert logistikk-konsept besluttet på overordnet nivå, men at de har operasjonelt handlingsrom 
til å fatte beslutninger når noe oppstår, slik at bestilte varer kommer frem til kunden i tide som førsteprioritet. Når vi ser på målinger av driftseffektivitet i selskapene finner vi en score rundt $95 \%$.

Denne logistikk-casen viser eksempler på hvordan oppdragsbasert ledelse kan anvendes og fungerer også i sivil sammenheng. Konkret så vi dette gjennom følgende: For det første definerer logistikkselskapene en overordnet målsetting knyttet til kundetilfredshet som vi oppfatter som intensjonsbasert. For det andre er hensikt og felles forståelse internalisert helt ut i organisasjonen. For det tredje føler hele organisasjonen en forpliktelse til oppgaven eller oppdraget. Sist, at det gis handlingsrom for kreativitet og målrettede initiativ på alle nivå i linjen. Samtidig er det viktig å understreke at selv om eksempelet har tydelige overlapp med en oppdragsbasert ledelsesfilosofi, oppfatter vi ikke at dette er et bevisst valg av ledelseskonsept i de aktuelle organisasjonene. Innenfor andre målområder i selskapene ser vi at ledelse er basert på mer tradisjonelle styringsog ledelsesmodeller.

\section{Ledelse gjennom intensjoner i offentlig sektor under covid-19-pandemien}

Covid-19-krisen har vært en samfunnsvekker med tanke på hvor sårbare vi er i vår globale æra for påvirkning i omgivelser vi ikke kan styre. Offentlig sektor ble i stor grad kastet inn i en situasjon hvor usikkerheten har vært stor, og tempo i utviklingen har vært dag-fordag basert. Situasjonen har blitt beskrevet som krigslignende tilstander og sammenlignet med andre verdenskrig. Gjennom ulike medier har vi observert hvordan ledelse og gjennomføring av tiltak har blitt håndtert.

12. mars står som startdatoen for den nasjonale håndteringen av krisen. Gjennom statsministeren, helseministeren og øvrige myndighetspersoner kommuniserte sentrale myndigheter nedstenging av all aktivitet i Norge som ikke var samfunnskritisk. Budskapet var enkelt og tydelig. Hensikten med tiltakene ble forklart med at smittekurven måtte flates ut og forsinkes. Begrunnelsen var at helsevesenet ikke hadde kapasitet til å ta imot et stort antall smittede og samtidig håndtere det 
«normale» sykdomsbildet. Frykten for at innbyggere skulle dø i helsekø var stor. Dette fremsto som myndighetenes intensjon. I ukene som fulgte så vi ulik respons fra utøvende virksomheter. Vi så eksempler på virksomheter tok aktive initiativ som var baserte på den kommuniserte intensjonen.

Ved Drammen sykehus ble det satt i gang organisering og tiltak som utvidet akutt-kapasiteten og klargjorde sykehuset for mottak av en økning i antall pasienter. Seksjonsoverlege Jørn Einar Rasmussen beskrev hvordan sykehuset økte akutt-kapasiteten fra 1 til 3 separate avdelinger: «Vi som jobber i front har en fordømt plikt til å være forberedt på scenarier som overskrider våre normale ressurser, og plikt til å ta vare på pasienter og ansatte» (Fremstad, 2020).

Andre slike initiativ så vi gjennom hvordan ordførere i ulike kommuner, som Frode Revhaug i Frosta kommune og Ida Pinnerød i Bodø kommune, iverksatte offensive karantenetiltak for å hindre mobilitet og smittespredning i befolkningen. Vi så imidlertid også en rekke eksempler på ledere i offentlige virksomheter som passivt pekte tilbake til sentrale myndigheter og etterspurte overordnede beslutninger, mer styring og flere direktiver.

Gjennom covid-19-pandemien så vi eksempler på lokale beslutninger og handlinger basert på en tydelig overordnet intensjon, og enkeltindividers målrettede initiativ. Dette viser hvordan oppdragsbasert ledelse som konsept kan utøves når behov for endringer ut over normale rutiner oppstår. Ledere i offentlig sektor (statsministeren, helseministeren, Folkehelseinstituttet, Helsedirektoratet) beskrev hvordan de oppfattet situasjonen som en læringsprosess, der det ble stilt krav til nye beslutninger daglig, basert på utvikling i situasjonsbildet. Målstyrt ledelse, handlingsplaner og forhåndsbestemte prosess- og prosedyrebeskrivelser som styringsverktøy måtte settes til side. Det vi imidlertid også kunne observere var hvordan dette var uttrykk for individuelle initiativ, og ikke kollektive handlinger basert på en felles ledelsesfilosofi. Dette er et eksempel på at oppdragsbasert ledelse kan være anvendbar i usikre omgivelser, men at vi på forhånd må ha utviklet felles ledelsesfilosofi og kultur i hele organisasjonen, som setter i gang målrettede initiativ i hele førstelinjen. 


\section{Perspektiver på ledelsesteorier i lys av oppdragsbasert ledelse}

I en diskusjon om hvorvidt oppdragsbasert ledelse kan utvikles som et vitenskapelig teoretisk perspektiv med verdi for sivile virksomheter i vår tid, gir det følgende en gjennomgang av de mest anvendte teorier om ledelse og hvordan oppdragsbasert ledelse sammenfaller med disse.

\section{Ledelsesdiskursen og teoretisk utvikling}

Forskning på ledelse fremstår som relativt fragmentert. Begrepet ledelse har aldri kommet i nærheten av en definisjon alle kan enes om, og brukes i en flora av forskjellige teorier og forestillinger (Wennes, 2016). For å si noe om hvorvidt ledelsesteorier er beskrivende for kjennetegn ved oppdragsbasert ledelse, redegjør vi på et overordnet nivå for en historisk utvikling av klassiske teorier om ledelse og noen hovedtrekk ved disse.

Taylorismens tanker om vitenskapelig arbeidsdeling gjorde sitt inntog i industrialiseringens tidsalder, rettet mot produktivitet og indre effektivitet i organisasjonen. Taylorismen hadde størst gjennomslag i teoriutvikling gjennom hele 1900-tallet, men preger fortsatt mye av dagens tenkning om ledelse og lederens rolle (Bungay, 2010; Klemsdal, 2018). Disse kalles gjerne for de klassiske ledelsesteoriene, hvor den sterke lederen er sentral, også kalt heroisk ledelse. Et vanlig skille har ligget mellom styring og ledelse. Tanker om ledelse, herunder meningsskaping, har vært et underordnet tema som Taylor er blitt kritisert for, da han pekte på at lønn var den eneste betydningsfulle kilde til arbeidernes opplevelse av mening (Klemsdal, 2018, s. 51).

\section{«Scientific management»}

I Taylors bok The Principles of Scientific Management (1911) er ideene basert på at markedet var i jevn vekst og omgivelser var forutsigbare. Fokus i organisasjonene var kapasitetsøkning og effektivitet. Et bærende prinsipp var leders ansvar for planlegging, styring og kontroll, og medarbeidere som skulle utføre enkle, oppdelte oppgaver. Den ideelle ansatte 
var en robot, og den ideelle lederen programmerer (Bungay, 2010). Industrialderens prinsipper for ledelse og organisering møter utfordringer når omgivelsene blir mer dynamiske og komplekse, slik vi ser det i det 21. århundre. Bungay (2010) peker på at de klassiske teoriene og modellene holder oss tilbake. Han presenterer behovet for en ledelsestilnærming hvor organisasjonen evner å omsette strategier i uforutsigbare omgivelser i rask bevegelse. Organisasjonen ses på som en fleksibel organisme, heller enn en programmerbar maskin (Bungay, 2010).

\section{«Management by objectives»}

Management by objectives (MBO) ble introdusert av Peter Drucker (1954). For mange er det fortsatt et grunnleggende konsept for virksomhetsstyring i mange organisasjoner. $\mathrm{MBO}$ skiller seg fra scientific management ved at det nå ikke er lønn, men involvering som vektlegges som motivasjonsfaktorer. Ledelsen definerer overordnede mål, hvoretter undergitte ledere involveres i å utarbeide delmål og handlingsplaner. MBO tar hensyn til at organisasjoner ikke lenger bare er industri med produksjon etter samlebåndsprinsipper, men etterhvert mer komplekse systemer med kompetente ekspert-medarbeidere innenfor ulike funksjoner. Målstyrt ledelse er en styringsmodell hvor detaljnivået er stort, og handlingsplaner baserer seg på at omgivelser er forutsigbare i en relativt lang planperiode. Det er mange som hevder med bekymring at innføringen av såkalte New Public Management-reformer i offentlig sektor har handlet om å installere en form for ledelsesbevissthet i medarbeiderne, hvor dette ikke først og fremst handler om delegert autonomi og myndighet, men heller om at medarbeiderne påtar seg etterprøvbare ansvar for budsjetter, resultater osv. (Klemsdal, 2018, s. 37).

Når vi ser $\mathrm{MBO}$ i sammenheng med oppdragsbasert ledelse finner vi sammenfallende tanker om overordnede mål og delegering av innflytelse. Drucker (1954) mener at det overordnede målet er styrende for videre arbeid, og det er viktig at det eksisterer god forståelse mellom ulike nivåer i organisasjonen om hvilke mål man arbeider mot. En hoveddistinksjon ligger i begrepene styring og ledelse. $\mathrm{MBO}$ er i hovedsak basert på styring. Styring er definert som en oppskrift på hvordan samarbeid 
skal finne sted, og handler om hvordan arbeid skal organiseres (Arnulf, 2020, s. 8). MBO er preget av dette ved at målene er spesifikke og har et høyt detaljnivå. Mål og delmål forplanter seg nedover i organisasjonen som «smarte mål» og handlingsplaner, som medarbeidernes prestasjoner og resultater blir målt mot. Ledelse handler i henhold til Drucker om å skape oppslutning, og om å påvirke innsatsvilje og samarbeid mot et felles mål. Kjennetegn ved oppdragsbasert ledelse er som beskrevet basert på en felles intensjon som integreres og aksepteres i hele organisasjonen, hvor planer har et så lavt detaljnivå som mulig, og hvor autoritet delegeres. Målstyrt ledelse fokuserer altså på hvordan arbeidet skal utføres, mens oppdragsbasert ledelse fokuserer på hvorfor arbeidet skal utføres.

Hovedtyngden av eksisterende forskning på målsettingsteori har karakteristisk nok dreid seg om stabile trekk og kjente oppgaver. Under slike omstendigheter er det mulig å definere målbildet ganske nøyaktig. Når oppgavene blir komplekse og ukjente, og konteksten er i stadig endring, er det i større grad utfordrende å detaljstyre konkrete mål og handlinger. I møte med uoversiktlige problemer er ikke målstyrt ledelse tilstrekkelig (Kaufmann \& Kaufmann 2015, s. 127). Utfordringen er at medarbeidernes fokus trekkes mot de resultatmål og detaljerte handlingsplaner de blir målt på. Det legges ikke til rette for kreativitet og selvstendige initiativ rettet mot situasjonsbetingede handlinger for å oppnå overordnede målsetninger.

\section{«New leadership approach»}

De klassiske teoriene har gjennomgått en utvikling fra trekkteorier, til atferdsteorier, og videre til situasjonelle teorier hvor forskere typisk har forsøkt å spesifisere situasjonsvariablene som modererer effektiviteten til forskjellige ledelsesmetoder (Parry \& Bryman, 2006, s. 3-4). I 1980-årene opplevde ledelsesforskningen en stor endring (Johansen \& Sætersdal, 2018, s. 237). Nye tilnærminger til ledelse (new leadership approach) signaliserte en ny måte å konseptualisere og søke lederskap på (Parry \& Bryman, 2006, s. 5). Ledelse ble nå forklart som det «å skape mening» gjennom å definere virkeligheten slik at folk ble bedre i stand til å handle (Johansen \& Sætersdal, 2017; Parry \& Bryman, 2006, s. 5). 
To av de mest sentrale teoriene fra new leadership approach er LMX og transformasjonsledelse (Parry \& Bryman, 2006, s. 5).

\section{«Leader-member exchange theory» (LMX)}

LMX teori ble først presentert på 8o-tallet, og står for leder-medarbeiderutveksling. LMX-teori løfter frem viktigheten av ledernes evne til å etablere relasjoner (Risan, 2012). Dette er også avgjørende i oppdragsbasert ledelse, men da gjennomgående i organisasjonens nivåer. Der LMX handler om hvordan relasjonsutvikling mellom ansatt og leder fører til god ledelse, retter oppdragsbasert ledelse oppmerksomheten mot hvordan relasjonsbygging i organisasjonen som helhet er avgjørende for god ledelse. Fleksibilitet og kreativitet er viktige kjennetegn ved oppdragsbasert ledelse. Her kan vi trekke linjer til LMX. I den mest utviklede formen for LMX er det utviklet en høy grad av tillit og gjensidig forståelse, som gir medarbeidere i gruppen stor grad av frihet. Dette er også kjernen i oppdragsbasert ledelse.

\section{Transformasjonsledelse}

Lederens intensjon er et av de viktigste kjennetegnene og styringsverktøyene innen oppdragsbasert ledelse, og selvstendighet og samarbeid er sentrale individuelle forutsetninger. Disse egenskapene beskrives også å være idealer innen transformasjonsledelse (Arnulf, 2020, s. 76). De militære doktrinene beskriver oppdragsbasert ledelse som det «å handle i tråd med lederens ånd». De samme ordene blir brukt i ledelsesteori for å beskrive transformasjonsledelse. Her er det altså tydelige likhetstrekk. I begge er idealisert innflytelse (en av de fire i-ene i transformasjonsledelse) et mål for å få folk til å tenke selv, men handle i organisasjonens og lederens ånd når vedkommende ikke er tilstede (Arnulf, 2020, s. 76).

Tillit og støttende ledelse er en viktig faktor i oppdragsbasert ledelse. Transformasjonsledelse vektlegger også disse egenskapene (Arnulf, 2020, s. 63). Det kan dermed argumenteres for at transformasjonsledelse skaper tillit, motivasjon og kreativitet (Glasø \& Thompson, 2013, s. 122). Flere studier støtter også at transformasjonsledelse er forbundet med opplevelse 
av mening med, og retning på arbeidet (Glasø \& Thompson, 2013, s. 125). Alle disse egenskapene er viktige også i oppdragsbasert ledelse.

\section{Den heroiske arven}

Tross utvikling bygger nesten alle de klassiske ledelsesteoretiske bidragene på det heroiske grunnsynet om ledelse - nemlig ledelse som lokalisert i én enkeltperson (Arnulf, 2020, s. 70; Bungay, 2010; Parry \& Bryman, 2006, s. 11; Wennes, 2016). Vi ser først de aller siste årene at en form for post-heroisk tenkning utfordrer teorier med forankring i tradisjonell tenkning om ledelse i organisasjoner på 1900-tallet. Gardner og kollegaer har gjort en gjennomgang av hvilke ledelsesteorier som er mest publiserte gjennom tre tiår, i periodene 1990-1999, 2000-2009 og 2010-2019, i The Leadership Quarterly (Lowe \& Gardner, 20oo; Gardner, Lowe, Moss, Mahoney \& Cogliser, 2010; Gardner et al., 2020). Forfatterne beskriver at mens de to første tiårene (1990-1999 og 2000-2009) viser begrenset utvikling i innhold, tema og metodisk tilnærming, så ser vi i den siste perioden (2010-2019) at ledelsesforskningen går i retning av å beskrive vår forståelse av ledelse som fenomen, og hvordan vi metodisk kan studere ledelse, så vel som praktiske implikasjoner (Gardner et al., 2020, s. 24).

\section{Post-heroisk tenkning}

De fleste alternativene til heroisk ledelsesteorier har handlet om å bringe flere meningsdimensjoner i spill i arbeidssituasjonene til medarbeiderne (Klemsdal, 2018, s. 51). Disse kalles gjerne post-heroiske teorier, og er motreaksjoner til de heroisk baserte teoriene (Arnulf 2020; Johansen \& Sætersdal, 2017; Wennes, 2016). Det er disse retningene som i størst grad, slik vi ser det, kan sammenlignes med oppdragsbasert ledelse. Militær oppdragsbasert ledelse legger også vekt på sjefen og sjefens intensjon, men sjefer skiftes ut ofte. Så det er sjefen som posisjon - ikke som person - det henvises til.

I dette perspektivet blir det lagt vekt på å frigjøre lederne fra ledelsesog styringsoppgaver slik disse ble organisert av Taylor og Drucker, samt 
å motivere og vise vei gjennom formuleringer av virksomhetens formål (Klemsdal, 2018, s. 32). Dette er i og for seg ikke nye tanker. Mary Parker Follett beskrev allerede i midten av 1920-årene hvordan lederens viktigste oppgave er å etablere forståelse for den totale situasjonen virksomheten befinner seg i - og behovet for at medarbeidere på alle nivå skjønte hva som må gjøres for at virksomheten skal fungere. Follet regnes som en forløper for det som kan oppfattes som nye og alternative teoretiske perspektiv på ledelse (Klemsdal, 2018). Her ser vi tydelig sammenfallende ideer med oppdragsbasert ledelse, hvor det å formulere virksomhetens formål samsvarer med sjefens intensjon, og en etablert forståelse av omgivelsene er i tråd med hvordan man forholder seg til eksterne omgivelser i oppdragsbasert ledelse. Andre begrep for lignende måte å tenke ledelse på, er delvis selvstyrte arbeidslag, og ledelse som grenseregulerende (Klemsdal, 2018, s. 34). Det snakkes også om lederløse organisasjoner, som gjerne ofte forstås som autonome team (Arnulf, 2020, s. 72). Teambasert organisasjonsmodell har mange likhetstrekk med oppdragsbasert ledelse (Arnulf, 2020, s. 70; Klemsdal, 2018, s. 34). Her nærmer vi oss teorier om ledelse som ganske presist omtaler oppdragsbasert ledelse, hvor tankene stammer fra sosioteknisk organisasjonsforskning (Klemsdal, 2018, s. 34). Medlemmenes selvregulering er kjennetegn i et team, og spissformulert kan man si at jo mindre ledelse et team trenger, jo bedre fungerer teamet (Arnulf, 2020, s. 72). Her ligger det et viktig skille sett i forhold til oppdragsbasert ledelse som teori, da oppdragsbasert ledelse ikke sees på som en «lederløs ledelse». Tvert imot spiller lederen en viktig rolle - ikke som en heroisk person, men som en viktig del av systemet og den «prosessen» ledelse er i organisasjonen.

\section{Avslutning}

Den første sentrale forskjellen mellom oppdragsbasert ledelse og klassiske ledelsesteorier, er hvordan disse teoriene forholder seg til omgivelsene. De klassiske ledelsesteoriene er utviklet gjennom et århundre med mye endring, men likevel relativt stabile omgivelser, forutsigbar utvikling og lineær vekst. Teorigrunnlaget dermed er preget av faktorer knyttet til interne organisatoriske faktorer og leder-medarbeider-relasjonen 156 
i et ledelse- og styringsperspektiv. En kritikk til ulike ledelsesteorier er med det at de ikke tilstrekkelig tar hensyn til behovet for situasjonsanalyser av den eksterne konteksten. Mot slutten av 1990-tallet ble det derfor gjennomført flere studier for å teste den situasjonelle validiteten til new leadership approaches, og av transformasjonsledelse spesielt (Parry \& Bryman, 2006, s. 8). Disse studiene gav oppmerksomhet til en lang rekke kontekstuelle faktorer som kan begrense handlingsrommet for organisasjonsendring og transformasjonsledere, som teknologi, bransjestruktur, internasjonalt handelsmiljø, nasjonal og internasjonal politikk, samt sosiale og kulturelle endringer i samfunnet (Parry \& Bryman, 2006, s. 8).

Militære operasjoner er alltid preget av høy kompleksitet og usikkerhet, og i militær tenkning har derfor omgivelsene vært det grunnleggende utgangspunkt for utvikling av ledelsesteorier og perspektiv. Begrepet VUCA World (Volatility, Uncertainty, Complexity, Ambiguity), ble ved inngangen til 1990-tallet introdusert av US Army War College som en følge av slutten på kald krig (Codreanu, 2016; Miller, Groth \& Mahon, 2018). Det politiske og militære bildet endret seg fra relativt oversiktlige fastlåste fronter, til en beskrivelse av en turbulent, kaotisk, usikker, kompleks og multilateral verden som en ny norm. Dette var en tid med store politiske, økonomiske og sosialsosiale endringer globalt. Også sivile organisasjoner retter oppmerksomheten fra i hovedsak internt fokus, til å måtte forholde seg til eksterne problemstillinger. Grint (2014, s. 243) beskriver dette som wicked problems og sier at «Wicked problems are complex, rather than just complicated - that is, they cannot be removed from their environment». Med dette verdensbildet som utgangspunkt, er det avgjørende at organisasjoner evner å være agile og responderende (Ulrich, Kryscynski, Brockbank \& Ulrich, 2017). Dette er helt i tråd med hele hensikten med oppdragsbasert ledelse, som er å manøvrere i den komplekse virkeligheten og imøtekomme dynamisk uforutsigbarhet.

Den andre viktige forskjellen mellom teorier om oppdragsbasert ledelse og klassiske ledelsesteorier, er forståelsen av ledelse som en prosess eller adferd i organisasjonen. Ledelse må forstås som både enkelt og komplekst, personlig og sosialt, sammensatt og komplisert (Wennes, 2016). Det blir dermed relevant å snakke om ledelse i et systemteoretisk perspektiv. «I et systemteoretisk perspektiv er ledelse en egenskap ved 
systemet, ikke noe som begynner og slutter ved lederen» (Arnulf, 2020, s. 77). Ulrich (2014) beskriver kompetanse, prosesser, kultur og ledelse som kapabiliteter i organisasjonen som gir verdiskapningsevne. Ledelse er med det ikke personorientert, men organisasjonsorientert. Parry og Bryman (2006, s. 21) oppsummerer sin artikkel «Leadership in Organisations» med at ett perspektiv står særlig frem: De påpeker at forskning på ledelse på et bemerkelsesverdig vis er frikoblet fra organisasjonsteori generelt, til tross for at de to feltene har klare sammenhenger. Beskrivelser av oppdragsbasert ledelse er her tydelige på at vi må se organisatoriske og individuelle betingelser i sammenheng, som en forutsetning og helt grunnleggende (Forsvaret, 2012, 2019; ADP, 2017; APD, 2019). Vi ser at oppdragsbasert ledelse har vært en fungerende ledelsesfilosofi helt tilbake til tidlig 180o-tall i militær sammenheng, men som først i vår tid utfordrer eksisterende teorier om ledelse. Post-heroiske teorier er altså en gammel tanke i militær sammenheng, i en ny sivil etikette. Forskningen har behov for å utvikle tenkningen fra industriell økonomi og scientific management, kunnskapsøkonomi med målstyring (management by objectives) og new leadership approaches, til vår tids kreative økonomi som preges av omskiftelige omgivelser og post-heroiske teorier om kompleksitet og samskapt ledelse.

\section{Konklusjon}

Det innledende spørsmålet kapittelet har drøftet var «Hva kan vi loere av det militore ledelseskonseptet oppdragsbasert ledelse som kan ha betydning for ledelse i sivile virksomheter $i$ vår tid?». Militære avdelinger har til all tid operert i usikre omgivelser. Virksomheter i vår tid står i et i økende grad uklart og komplekst situasjonsbilde, som er sammenlignbart med det militære avdelinger opplever, og som må håndteres daglig av ledere i hele linjen. Oppdragsbasert ledelse som militært ledelseskonsept bidrar med erfaringer med hvordan ledelse kan ses på som en del av det organisatoriske systemet. Ledelse og lederskap utøves gjennom posisjon, og i mindre grad med fokus på person.

Begrepet oppdrag oppfattes gjerne som en militær form. I sivil sammenheng kan begrepet intensjon fange opp det dette kapittelet søker å 
beskrive, og være mer anvendelig. Militær tradisjon og ledelsesfilosofi kommer til uttrykk som intensjonsbasert ledelse, kjennetegnes ved delegert autoritet og disiplinert autonomi, og utøves til beste for organisasjonen. For å overføre det militære ledelseskonseptet oppdragsbasert ledelse til sivil anvendelse, foreslås derfor intensjonsbasert ledelse som begrep. Kan oppdragsbasert ledelse som militært ledelseskonsept utvikles til et vitenskapelig teoretisk fundament for ledelse generelt? Svaret på det er at det kan være relevant å utvikle intensjonsbasert ledelse som teoretisk bidrag, som har verdi med tanke på å forstå ledelse som organisasjonsadferd i komplekse omgivelser. Teoriutvikling knyttet til intensjonsbasert ledelse i sivil sammenheng fordrer i så fall vitenskapelige studier innenfor en relevant kontekst.

\section{Referanser}

Army Doctrine Publication [ADP]. (2017, 31. mars). Army doctrine publication: Land operations (AC 71940). Hentet fra https://www.gov.uk/government/publications/ army-doctrine-publication-operations

Army Publishing Directorate [APD]. (2019, 31. juli). Mission command: Command and control of army forces (ADP 6-o). Hentet fra https://armypubs.army.mil/ ProductMaps/PubForm/Details.aspx?PUB_ID $=1007502$

Army Publishing Directorate [APD]. (2012, mai). Army doctrine publication ADP 6-o mission command. Hentet fra https://caccapl.blob.core.usgovcloudapi.net/ web/repository/doctrine/adp6-o.pdf

Arnulf, J. K. (2020). Hva er ledelse. (2. utg.). Oslo: Universitetsforlaget.

Bungay, S. (2010, 2. november). Mission command: An organizational model for our time. Harvard Business Review. Hentet fra https://hbr.org/2010/11/missioncommand-an-organizat

Codreanu, A. (2016). A VUCA action framework for a VUCA environment. Leadership challenges and solutions. Journal of Defense Resources Management, 7 (2). Hentet fra http://journal.dresmara.ro/issues/volume7_issue2/o3_codreanu_ vol7_issue2.pdf

Danielsen, T. (2018). Making warriors in a global era. An ethnographic study of the Norwegian naval special operations command. Lanham: Lexington Books.

Drucker, Peter F. (1954). The practice of management. New York: Harper.

Fangen, K. (2010). Deltagende observasjon (2. utg). Bergen: Fagbokforlaget.

Forsvaret. (2014). Forsvarets fellesoperative doktrine. Oslo: Forsvarsstaben. Hentet fra http://hdl.handle.net/11250/224031 
Forsvaret. (2019). Forsvarets fellesoperative doktrine. Oslo: Forsvarsstaben. Hentet fra http://hdl.handle.net/11250/2631948

Forsvaret. (2012, 1. juni). Forsvarssjefens grunnsyn på ledelse i Forsvaret [Policy]. Oslo: Forsvarets høgskole. Hentet fra https://regelverk.forsvaret.no/ fileresult?attachmentId $=4632216$

Fremstad, M. (2020, 27. mars). -Må forberede oss på italienske tilstander [Intervju med seksjonsoverlege J. E. Rasmussen]. TV 2. Hentet fra https://www.tv2. no/a/11331752/

Gardner, W. L., Lowe, K. B., Moss, T. W., Mahoney, K. T. \& Cogliser, C. C. (2010). Scholarly leadership of the study of leadership: A review of The Leadership Quarterly's second decade, 2000-2009. The Leadership Quarterly, 21(6), 922-958. https://doi.org/10.1016/j.leaqua.2010.10.003

Gardner, W. L., Lowe, K. B., Meuser, J. D., Noghani, F., Gullifor, D. \& Cogliser, C. C. (2020). Scholarly leadership of the study of leadership: A review of The Leadership Quarterly's third decade, 2000-2009. The Leadership Quarterly, 31(1). https://doi. org/10.1016/j.leaqua.2019.101379

Geyer, M. (1986). German strategy in the age of machine warfare. I P. Paret (Red.), Makers of modern strategy from Machiavelli to the nuclear age. Oxford: Oxford University Press.

Glasø, L. \& Thompson, G. (2013). Transformasjonsledelse. Oslo: Gyldendal Norsk Forlag.

Grint, K. (2014). The hedgehog and the fox: Leadership lessons from D-Day. Leadership, 1o(2) 240-260. https://doi.org/10.1177/1742715014526479

Johansen, O. \& Sætersdal, H. (2018). HR og personalledelse (2. utg.). Bergen: Fagbokforlaget.

Kaufmann, G. \& Kaufmann, A. (2015). Psykologi i organisasjon og ledelse (5. utg.). Bergen: Fagbokforlaget.

Klemsdal, L. (2018). Hva trenger vi ledere til? Oslo: Gyldendal Norsk Forlag.

Lowe, K. B \& Gardner, W. L. (2000). Ten years of The Leadership Quarterly: Contributions and challenges for the future. The Leadership Quarterly, 11(4), 459-514. https://doi.org/10.1016/S1048-9843(oo)ooo59-X

Maciejewski, J. (2019, 31. oktober). How the British army's operations went agile. McKinsey Quarterly. Hentet fra https://www.mckinsey.com/business-functions/ organization/our-insights/how-the-british-armys-operations-went-agile\#

Martin, G. (2017). Of garbage cans and paradox: Reflexively reviewing design, mission command, and the gray zone. Journal of Military and Strategic Studies, $17(4)$.

Miller, C. C. J. M, Groth, O., \& Mahon, J. F. (2018). Management innovation in a VUCA world: Challenges and recommendations. California Management Review, 61, 5-14. https://doi.org/10.1177/0008125618805111 
Parry, K. W. \& Bryman, Alan. (2016). Leadership in organizations. I S. R. Clegg, C. hardy, T. B. Lawrence \& W. R. Nord (Red.), The SAGE handbook of organization studies (s. 446-469). https://doi.org/10.4135/978-1-8486-o803-0.n14

Risan, H. (2012). Dyadisk lederskap. Magma, 2, 67-74. Hentet fra https://www. magma.no/dyadisk-lederskap

Schiermer, B. (2013). Til tingene selv: om hermeneutisk fænomenologi. I B. Schiermer (Red.), Fonomenologi: Teorier og metoder (s. 15-43). København: Hans Reitzels Forlag.

Saunders, M. N. K., Lewis, P., Thornhill, A. (2019). Research methods for business students (8. utg.). Pearson.

Taylor, F. W. (1911). The principles of scientific management. New York: Harper Brothers.

Tøllefsen, T. O. (2019, 13. juni). Helmuth Johannes Ludwig von Moltke. I Store norske leksikon. Hentet fra https://snl.no/Helmuth_Johannes_Ludwig_von_Moltke

Ulrich, D., Kryscynski, D., Brockbank, W. \& Ulrich, M. (2017). Victory through organization. New York: McGraw-Hill Education.

Ulrich, D. (2014). The future targets or outcomes of HR work: Individuals, organizations and leadership. Human Resource Development International, 17(1), 1-9. https://doi.org/10.1080/13678868.2013.825144

Watson, T. J. (2011). Ethnography, reality, and truth: The vital need for studies of 'how things work' in organizations and management. Journal of Management Studies, 48(1), 2002-217.

Wennes, G. (2016). Ledelsens sanne ansikt. Magma, 2, 22-27. Hentet fra https://www. magma.no/ledelsens-sanne-ansikt

Williams, T. (2016, 26. april). Mission command leadership and the U. S. Army [Internett]. The Strategy Bridge. Hentet fra https://thestrategybridge.org/thebridge/2016/4/26/

Yin, R. K. (2018). Case study and application: Design and methods (6. utg.) Thousand Oaks, CA: Sage.

Yardley, I. \& Kakabadse, A. (2007). Understanding mission command: A model for developing competitive advantage in a business context. Strategic Change, 16(1-2), 69-78. https://doi.org/10.1002/jsc.779

Zetterling, N. (2003). Blitzkrieg: From the ground up. Pennsylvania: Casemate Publishers. 



\title{
Frelsere eller parasitter? Ledermotiver for bruk av IT-konsulenter
}

Jarle Bastesen

Høyskolen Kristiania

\section{Elin Ørjasæter}

\section{Høyskolen Kristiania}

\begin{abstract}
The high degree of digitalization in Norway depends on external ITconsultants working on internal projects in private firms as well as in public organizations. This is partly because of organizations' need for key skills, and partly because of the need for the flexibility. The consultants are employed in flexible non-standard employment contracts with their customers, but usually have standard employment contracts with their "real" employer: the consulting firm. While managers in the customer (focal) firms highly appreciate the key competences and flexibility in these arrangements, they are also concerned about losing control of their own strategic choices, due to their own lack of competence. They also worry about how internal budget and decision procedures fuel the use of consultants, on behalf of building internal competencies by recruiting more of their own standard employment staff.
\end{abstract}

Keywords: the flexible firm, external consultants, contingent labor, managerial challenges

\section{Innledning}

Topartsrelasjonen, med et avtaleforhold bestående av arbeidsgiver på den ene side og arbeidstaker på den andre, er vanlig og også normgivende i norsk arbeidsliv. De siste årene har vi sett økt mangfold og kompleksitet

Sitering av denne artikkelen: Bastesen, J. \& Ørjasæter, E. (2020). Frelsere eller parasitter? Ledermotiver for bruk av IT-konsulenter. I J. Bastesen, B. K. Lange, H. E. Næss \& A. N. Thon (Red.), Ledelse av mennesker $i$ det nye arbeidslivet (Kap. 6, s. 163-184). Oslo: Cappelen Damm Akademisk. https://doi.org/10.23865/ noasp.118.ch6

Lisens: CC-BY 4.o. 
i arbeids- og organisasjonsformer (Nesheim, 2009). Det er eksempelvis blitt mer vanlig å leie inn arbeidskraft og utkontraktere arbeidsoppgaver, en trend som er enda mer tydelig i andre OECD-land (Eurofond, 2017; Standing, 2011). Mangfoldet av tilknytningsformer øker stadig, også slik at den rent arbeidsrettslige tilknytningen blir mer uklar (Roverud, Kjølvik, Nesheim \& Jesnes, 2017). I dette kapittelet tar vi utgangspunkt i en av de mange fasettene ved såkalt atypisk arbeid, nemlig norske virksomheters innleie av høykompetent arbeidskraft innenfor IT, det som til daglig kalles IT-konsulenter. I arbeidsrettslig forstand vil de fleste IT-konsulentene være i et topartsforhold med sin arbeidsgiver, nemlig konsulentselskapet. Når vi likevel kategoriserer forholdet som atypisk arbeid, er det fordi de (som regel) har kundens arbeidsplass som arbeidssted, og er under kundens styring og ledelse. Det er også betegnende at de kalles for «innleide» av kunden, en terminologi vi også bruker videre i artikkelen. Vi kaller derfor dette for et treparts-forhold i videre tekst, selv om dette i henhold til det arbeidsrettslige forholdet i noen tilfeller kan være feil.

Det har vært en viss forskningsmessig oppmerksomhet om fordeler og utfordringer for konsulenter i trepartsforholdet mellom utleier, konsulent og kunde (innleier). Det har vært mindre oppmerksomhet rundt motivasjonen for dem som inngår kontrakten med utleier og konsulent, samt kundens lederutfordringer knyttet til å lede både fast ansatte og innleide konsulenter (Nesheim, Fahle \& Tobiassen, 2014). Vi ønsker i dette kapittelet for det første å sette søkelyset på kundenes og spesielt lederes motiver for å inngå slike kontrakter. Lederne som leder prosjekter hvor det inngår både innleide konsulenter og fast ansatte, sitter typisk i en mellomlederposisjon i virksomheten. For det andre ønsker vi å vurdere fordelene og ulempene ved bruk av innleid arbeidskraft sett fra et lederperspektiv.

Vi mener at ledelse av innleid, høykompetent arbeidskraft er et relevant og dagsaktuelt fenomen og forske på. Rådgivings- og konsulentnæringen er en stor og viktig næring, som stod for 6 prosent av verdiskapningen i næringslivet i 2016 - større enn for eksempel både reiseliv og sjømatnæringen hver for seg (Wifstad, Stokke \& Skogli, 2017).

IT-konsulenter utgjorde da over 30 prosent av de ansatte i rådgivingsnæringen. De er spesielt viktige i å hjelpe virksomheter til å løse sine digitale utfordringer. Denne hjelpen er viktig for at virksomhetene kan 
henge med i den teknologiske utviklingen, utnytte nye forretningsmuligheter og skaffe seg konkurransefortrinn. Det innebærer at de innleide konsulentene ofte jobber med kjerneoppgaver i virksomhetene.

Tradisjonelt sett har en tenkt at det er de fast ansatte som arbeider med virksomhetens kjernevirksomhet, og man leier inn ekstern arbeidskraft dersom man trenger numerisk og finansiell fleksibilitet $i$ takt med svingninger i etterspørselen eller produksjonen (Atkinson, 1984). Innenfor denne tradisjonen arbeider altså ikke de innleide med kjerneoppgavene. De leies inn på korte oppdrag for å ta av topper $\mathrm{i}$ arbeidsbelastningen, og krever dermed mindre ledelse og oppfølging. Det er derfor spesielt interessant å undersøke ledelse av IT-konsulenter, da disse ofte jobber med kjerneoppgaver og leies inn på oppdrag over lang tid, gjerne over flere år. Innen forskning på innleid arbeidskraft har det vært lite søkelys på ledelse av innleid arbeidskraft (Nesheim et al., 2014) og innleie av høykompetent arbeidskraft (Kunda, Barley \& Evans, 2002).

Kapitlet bygger på en empirisk studie gjennomført i norske selskaper som tilbyr tjenester hvor det er behov for IT-kompetanse i utviklingen av disse. Tjenestene spenner fra offentlig forvaltning, bankvirksomhet, logistikk, maskinlæring, salg og markedsføring. Informantene har mellomlederstillinger i virksomheter på mellom fem og ti tusen ansatte. Kunden (tjenesteleverandøren) inngår en kontrakt med et IT-konsulentfirma, som sender sine IT-konsulenter på oppdraget, oftest slik at konsulenten er fysisk plassert i kundens lokaler. Prosjektene vi har inkludert i studien har lang varighet, uten at det betyr at konsulenten må ha vært med på prosjektet i lang tid. Vi er ikke opptatt av relasjonen mellom konsulentfirma (utleier) og kunden, men mellom kunden og konsulent, og spesifikt relasjonen mellom leder (hos kunden) og konsulent. Vi tar utgangspunkt i det veletablerte funnet at tilgang til kompetanse er en viktig driver for innleie av IT-konsulenter (Andreassen, Ryberg, Grotle, Slettum \& Nesheim, 2014; Bastesen \& Nesheim, 2008; Nesheim, Olsen \& Kalleberg, 2007). I tillegg viser vår egen undersøkelse at det økonomiske handlingsrommet for å leie inn konsulenter ofte er større enn for fast ansettelse, slik at økonomiske rammer også fremstår som en viktig motivasjon for bruken av konsulenter. Vi diskuterer tre momenter som fremstår viktige 
for informantene når de beskriver fordelene og utfordringene ved å lede konsulenter sammenlignet med fast ansatte. Det er 1) selve styringen av konsulenter, 2) konsulenter som kunnskaps- og beslutningsstøtte, og 3) strategiske utfordringer ved bruk av konsulenter i kjerneoppgaver. Vi tar også med et fjerde moment, nemlig 4) faren for kunnskapslekkasje, fordi dette i forskningslitteraturen er nevnt som en mulig ulempe ved bruk av IT-konsulenter (se f.eks. Matusik \& Hill, 1998).

I dette kapittelet vil vi først redegjøre for det teoretiske fundamentet og tidligere empirisk forskning på feltet. Deretter presenterer vi metoden for vår empiriske undersøkelse. Videre diskuterer vi lederes motiv for å leie inn IT-konsulenter, interne beslutningsprosesser for ressurs- og kompetansetilgang, og deres opplevelse av fordeler og utfordringer med å leie inn IT-konsulenter. Kapittelet avsluttes med en konklusjon og forslag til videre forskning.

\section{Teoretisk rammeverk}

En virksomhet har mange organisatoriske muligheter til å få utført sitt arbeid. Noen av avveiningene lederne gjør handler om i hvilken grad de skal bruke egne ansatte, utkontraktere hele eller deler av arbeidet, benytte alternative tilknytningsformer til arbeid, eller kombinasjoner av disse (Anand \& Daft, 2007; Atkinson, 1984; Lepak \& Snell, 1999; Pfeffer \& Baron, 1988). I dette kapittelet setter vi søkelyset på en ordning hvor konsulenter ansettes i et konsulentselskap, for å igjen leies ut til en virksomhet som har behov for arbeidskraften. Konsulentselskapet betaler lønn og har arbeidsgiveransvar, men innleievirksomheten (kunden) har ansvar for å organisere og lede arbeidet (Nesheim, 2016; Olsen, 2016).

Vi kan skille mellom bemanningsbyråer som formidler arbeidskraft på generell basis, og konsulentselskaper som formidler spesifikk kompetanse innenfor et bestemt felt. Grensene mellom disse to er ikke alltid åpenbare, men i vårt tilfelle handler det om innleie av IT- kompetanse og rådgiving som normalt krever relevant universitetsutdanning på bachelor- eller masternivå. De jobber gjerne som programmerere, utviklere, programvareeksperter og prosjektledere. Konsulentene er ordinært ansatt i konsulentselskapet, og arbeidsgiver tar risikoen for 
oppdragsinngangen. Dette gir ansatte i konsulentselskapene et mer reelt stillingsvern enn tradisjonen har vært for bemanningsselskapene (Eldring \& Ørjasæter, 2018). I tillegg har IT-konsulenten normalt sett høyere lønn og høyere kompetanse enn en typisk arbeider fra bemanningsbyrå. I diskusjonen om atypiske tilknytningsformer til arbeid er det derfor helt vesentlig å skille mellom høytlønt/høykompetent arbeidskraft og lavtlønt/lavkompetent, slik det gjøres innenfor forskningen ved å skille mellom "profficians/consultants» og "the precariat» (Kalleberg, 2018; Kalleberg \& Vallas, 2018; Standing, 2014). Mens «profficians/ consultants» tilfører innleie kompetanse bedriften selv mangler, vil «the precariat» tilføre bedriften arbeidskraft av en type som enten finnes i bedriften fra før, eller som krever liten grad av formell kompetanse og opplæring. Dette er selvfølgelig ikke absolutt. Også blant IT-konsulentene kan det f.eks. gjøres programmering som også fast ansatte kunne ha gjort, dersom de hadde hatt kapasitet.

Å leie inn midlertidig arbeidskraft har, særlig for store virksomheter, blitt sett på som en administrativ utfordring. Fremveksten av agenter, utleiebyråer og konsulentbyråer har gjort det langt enklere å håndtere midlertidig arbeidskraft, da det er utleiebyrået som tar den administrative håndteringen av sin ansatte, mens utleier og kunde inngår en kontrakt som regulerer avtaleforholdet (Ashford, George \& Blatt, 2007). I tillegg har det for mange blitt mer attraktivt å arbeide som utleid konsulent fordi det er fleksibelt, man får varierte arbeidsoppgaver, man slipper å forholde seg til organisatoriske politiske prosesser, og det gir ofte høyere lønn (Ashford, George \& Blatt, 2007). Fremveksten av å leie inn konsulenter handler derfor ikke bare om at det har blitt enklere for kunden å leie inn slik arbeidskraft, men også fordi mange av de mest kompetente teknologene selv ønsket en friere tilknytning (Barley \& Kunda, 2004; Kalleberg, 2000; Matusik \& Hill, 1998). Også norsk forskning peker på at mange konsulenter foretrekker denne arbeidsformen, både på grunn av lønn og av hensyn til egen kompetanseutvikling (Nesheim, 2009). Muligheten for å utvikle egen kompetanse oppleves av mange som større for en konsulent som får ta oppdrag hos ulike kunder enn som fast ansatt hos en innleiebedrift. Den enkeltes kompetanse oppleves som den største trygghet for inntekt og arbeid. 
Forskningen som omhandler innleide konsulenter har i stor grad vært orientert rundt den innleide eller den ansatte, og relasjonen mellom den innleide, ansatte og ledere, men mindre sett fra et leder- og organisasjonsperspektiv (Ashford et al., 2007; Connelly \& Gallagher, 2004). Ifølge Atkinson (1984) er fleksibilitet virksomhetens rasjonale for bruk av innleid arbeidskraft, og dette deles inn i numerisk, funksjonell og finansiell fleksibilitet. Numerisk fleksibilitet handler om å raskt kunne skalere opp og ned arbeidstokken etter behov. Funksjonell fleksibilitet handler om å kunne stokke om på bemanningen mellom ulike aktiviteter og oppgaver. Finansiell fleksibilitet handler om muligheten for å omdisponere midler etter behov, spesielt å kunne spare på lønnsmidler ved å bare leie inn arbeidskraft når det trengs. Noen virksomheter bruker i tillegg innleid arbeidskraft som en mulighet for å teste ut potensielle fast ansatte (Ashford et al., 2007; Bastesen \& Nesheim, 2008). Ashford et al. (2007) har i sin oversiktsartikkel også identifisert strategiske fordeler, som at virksomheten og dens ansatte kan dyrke sin kjernekompetanse og utvikle sine konkurransefortrinn, mens innleid arbeidskraft kan utføre arbeid som ligger utenfor kjerneaktivitetene.

Det virker som det likevel er blitt mer vanlig at innleide konsulenter også benyttes i kjerneaktiviteter. Matusik og Hill (1998) hevder at den teknologiske akselerasjonen krever at bedrifter bruker innleide også i kjernefunksjonene, og Barley og Kunda (2004) forventer mer bruk av konsulenter som jobber med kjernevirksomhet fremover. I norsk kontekst finner Nesheim et al. (2014) at konsulentene jobbet med kjerneaktivitetene i virksomhetene de undersøkte (oljesektoren), selv om virksomhetens offisielle politikk var at konsulentene ikke burde jobbe med dette.

Ledernes motiv for å velge konsulenter fremfor fast ansatte sentrerer i forskningen rundt to hovedtemaer. Det ene er ekstra kapasitet (numerisk fleksibilitet), det andre er behov for spesialkompetanse (Andreassen et al., 2014; Bastesen \& Nesheim, 2008; Nesheim et al., 2007). Numerisk fleksibilitet handler som nevnt om en fleksibel arbeidsstyrke. Spesialkompetanse handler om kompetanse virksomheten ikke har, eller som det tar tid å utvikle internt, eventuelt som de bare trenger en kort periode. I tillegg kan det være nyttig for en virksomhet å få se på problemet 
fra nye vinkler. En ser at kreativitet og problemløsing blir viktigere i kunnskapsintensive virksomheter (Ashford et al., 2007). Nesheim et al. (2014) finner at det er enkelt å terminere konsulentenes kontrakter, og dette sikrer numerisk fleksibilitet. I tillegg har ikke kunden som leier inn konsulenten noe formelt arbeidsgiveransvar for denne, og kan ha en armlengdes avstand og en mer operasjonelt orientert relasjon til konsulenten. Ledere kan også velge å bruke innleid arbeidskraft for å redusere organisatorisk «støy» ved at innleide konsulenter genererer mindre uttalt misnøye enn det fast ansatte kan gjøre (Ashford et al., 2007). Innleid arbeidskraft er mer opptatt av å løse oppdraget enn å involvere seg i interne politiske prosesser, og kan dermed være enklere å håndtere for ledere.

I studier av ledernes risiko ved å bruke konsulenter har det særlig vært pekt på kunnskapslekkasje, altså risikoen for at konsulenten tar med seg kunnskap til andre, kanskje konkurrerende organisasjoner (Matusik \& Hill, 1998). Selv med risiko for kunnskapslekkasje vil likevel virksomheter forsøke å utvikle bedriftspesifikk kompetanse for å skape konkurransefortrinn. Da slike prosjekter må utvikles av både ansatte og innleid arbeidskraft, kan ikke utvikling av humankapital lenger sees på som utelukkende bedriftsspesifikk (Kinnie \& Swart, 2020). En annen risiko som nevnes i litteraturen er at inntreden av innleid arbeidskraft kan føre til dårligere relasjoner og svekket tillit mellom de ansatte og lederne i virksomheten (Ashford et al., 2007).

Når det gjelder lederes motiver for å leie inn IT-konsulenter vil vi i dette kapittelet stille spørsmål om hvorvidt de leies inn på basis av behov for spisskompetanse, numerisk fleksibilitet, finansiell fleksibilitet eller en kombinasjon av disse. For å forstå lederes opplevelse av fordeler og utfordringer med å leie inn IT-konsulenter stiller vi spørsmål om a) hvordan ledere opplever å styre og lede IT-konsulenter sammenlignet med fast ansatte; b) hvorvidt lederne opplever at konsulentene kan gi annen kunnskapsstøtte til lederne enn fast ansatte; c) om konsulentenes eksperthjelp kan være utfordrende med hensyn til virksomhetens selvstendighet $\mathrm{i}$ strategiske beslutninger; d) om det at konsulentene stadig er på oppdrag hos nye kunder oppleves som risiko for kunnskapslekkasje og/eller en mulighet for erfaringsutveksling. 


\section{Metode og data}

I denne studien ønsker vi å se nærmere på lederes motiver for og opplevelse av fordeler og utfordringer med å leie inn IT-konsulenter til bruk i virksomhetens kjerneoppgaver. Undersøkelse av et slikt fenomen (i dette tilfelle ledelse av innleid høykompetent arbeidskraft) kalles ofte en casestudie (Yin, 2014). I følge Eisenhardt (1989, s. 534) fokuserer casestudier på «understanding the dynamics present within single settings». Vårt mål er ikke å gå i dybden på en enkelt virksomhet, men å øke vår forståelse av fenomenet, og dette kan betegnes som en instrumentell casestudie (Stake, 2000).

Vi har avgrenset studien til ledelse av innleide IT konsulenter, og benytter en formålsbestemt utvelgelse av informanter (Johannesen, Tufte \& Christoffersen, 2016). Undersøkelsen bygger først og fremst på intervjuer av 14 ledere som har vært ledere for innleide IT-konsulenter i tillegg til faste ansatte. I tillegg har 7 IT-konsulenter og 1 leder av et ITkonsulentselskap (som leier ut IT-konsulenter) blitt intervjuet for å få frem deres perspektiver.

Studien bygger på etablerte teorier, som beskrevet i det teoretiske rammeverket over. Samtidig er fenomenet vi ser på mindre studert, og dermed ønsket vi muligheten for å utforske sammenhenger og få en dypere forståelse av informantenes opplevelser av ulike situasjoner. Av den grunn valgte vi å utforme og gjennomføre semistrukturerte intervjuer (Klenke, 2008). Intervjuguiden var bygget opp rundt bestemte temaer med spørsmål under hvert tema. Tema og spørsmål var basert på det teoretiske grunnlaget, samt koding av intervjuer fra innledende fase av prosjektet (et år i forveien av denne studien). Det var ulike intervjuguider for ulike roller. Intervjuene ble gjennomført på telefon eller digitalt (Skype/Zoom) på grunn av covid-19-situasjonen. Det ble tatt opptak av intervjuene, som deretter ble transkribert. De transkriberte intervjuene ble deretter kodet av forskerne hver for seg, før de ble sammenstilt i et felles kodeskjema til slutt.

Studien omfatter intervjuer med ledere og konsulenter i ulike bransjer, offentlige og private virksomheter, av ulik størrelse. Vår undersøkelse av dette fenomenet i ulike kontekster kan dermed kategoriseres som en flercasestudie (Yin, 2014). Det gir oss mulighet til å se om det 170 
er likheter og forskjeller mellom lederes motiver og opplevelser. Vi har få analyseenheter, men datamaterialet kan likevel gi indikasjoner om mulige interessante fellestrekk og/eller forskjeller. En fordel med flercasestudie versus en enkel case, er at fellestrekk på tvers av flere caser kan indikere at funnene er relevante i flere ulike virksomheter. Ifølge Cook og Campbell (1979) kan slik generaliserbarhet - om sammenhengene kan generaliseres til andre settinger enn de som er undersøkt - benevnes som ekstern validitet.

Fem ledere ble intervjuet av masterstudenter i en innledende fase av forskningsprosjektet i 2019. De samme lederne ble intervjuet igjen av forskerne i 2020. Hensikten var å se om svarene på de to ulike tidspunktene er sammenfallende, og på den måten teste dataenes reliabilitet eller pålitelighet. Det gikk nesten et år mellom de to intervjuene, og vi finner at svarene er sammenfallende over tid.

Vi har intervjuet fjorten ledere i syv ulike selskaper. I de største selskapene er flere ledere fra ulike avdelinger intervjuet for å se etter likheter og/eller ulikheter innen samme selskap. Funnene fra samme selskap var rimelig konsistente, slik at de ulike intervjuene gav heller flere nyanser i datamaterialet. Dette styrker dataenes reliabilitet. Fem av konsulentene som ble intervjuet jobbet under fem av lederne som ble intervjuet. Dette for å styrke dataenes pålitelighet, samt få frem eventuelle nyanser sett fra konsulentenes side.

\section{Lederes motiver for å leie inn IT-konsulenter Fleksibel spisskompetanse}

Gjennomgående i hele datamaterialet er ledernes vektlegging av at de trenger konsulentenes spisskompetanse. Denne omtales som «helt nødvendig», og lederne er «helt avhengige» av å få leid inn konsulenter for å skaffe seg denne kompetansen. Lederne rapporterer at det er vanskelig å få ansatt mennesker med denne kompetansen. Samtidig sier de at det er relativt enkelt å få leid inn kompetansen. Lederne fremstiller konsulentene som virksomhetens redning eller «frelsere», fordi alt skal skje raskt: nye prosjekter «ruller på», og konsulentene kan begynne raskt og bli så lenge det er behov for dem. Tradisjonelt har forskningen vært opptatt av 
numerisk fleksibilitet versus spesialkompetanse (Nesheim et al., 2007). Selv om det er spesialkompetanse som vektlegges av lederne, og ikke numerisk fleksibilitet, er det likevel en form for fleksibilitet lederne er opptatt av. Denne handler om at konsulentene alltid har oppdatert kompetanse som kan hentes inn raskt, og som kan bli værende nøyaktig så lenge det rr behov for den.

Det er flere viktige aspekter ledere må vurdere ved innleie. Det første handler om timing. Anledningen til å kunne håndplukke en spesifikk kompetanse på akkurat det tidspunktet den er viktig, for så å koble den av når det passer, oppleves av mange ledere som nødvendig for å oppnå teknologisk utvikling og endring i organisasjonene. Med dagens voldsomme digitaliseringstempo er dermed konsulentene blitt organisasjonenes redning. Kombinasjonen av «raskt av og på» og nøkkelkompetanse utgjør en stor verdi for kunden, som de er villig til å betale mye for. Dette sammenfaller i stor grad med funnene til Nesheim et al. (2014), hvor de ser at et viktig motiv for ledere er at kontraktene fort og enkelt kan termineres når det ikke er behov for konsulentene mer. Vi ser også at det er like viktig med fleksibiliteten i det tidspunktet behovet oppstår, at det er lett å få tak i god og riktig kompetanse raskt. Ved fremveksten av konsulentselskaper som leier ut sin kompetanse er den administrative håndteringen av å få tak i arbeidskraften og håndtere kontraktsforholdet effektivisert (Ashford et al., 2007).

Det andre aspektet handler om oppdatert kompetanse. På spørsmål om det er viktig for lederne å kunne ta konsulentbruken opp og ned raskt, svarer samtlige at det er svært viktig. Ledernes svar er tett knyttet opp til spisskompetansen konsulentene besitter. Nye prosjekter trenger ny type kompetanse, det er derfor gamle konsulenter skal ut og nye inn. Verdien av å kunne ta folk raskt ut og inn er altså ikke knyttet til numerisk fleksibilitet slik det ble beskrevet hos Atkinson (1984), men derimot til det å få riktig spisskompetent kompetanse til rett tid i endringsprosjekter. En leder eksemplifiserer med at det i starten av et prosjekt trengs backend-kyndige konsulenter, mens det senere i prosjektet, eventuelt klassifisert som et nytt prosjekt, trengs frontend-kyndige. Konsulentenes syn på egen kompetanse er helt parallelt med ledernes: De er spesialister på det de gjør, de er uerstattelige, men bare i akkurat den fasen av prosjektet 
der denne spesielle kompetansen er nødvendig. En av konsulentene forklarer det slik: «Det finnes bare 600 mennesker med min type kompetanse i hele verden». Når IT-verdenen er så systemspesifikk og global som dette, virker det opplagt mer hensiktsmessig, både for innleievirksomhetene, for konsulenten selv, og for samfunnet, at denne konsulenten ikke «låses inne» i en virksomhet, men tvert imot jobber som konsulent, enten hos et konsulentselskap eller hos en stor, global leverandør som leier ut konsulenter for implementering av sine systemer.

Konsulenter tilfører organisasjonene unik kompetanse som er kritisk viktig for dem, og som er vanskelig å få tak gjennom de fast ansatte. Vår studie bekrefter betydningen av kombinasjonen av kompetanse og fleksibilitet: Nøkkelkompetanse må inn på nøyaktig riktig tidspunkt, for så å kunne kuttes i det det aktuelle prosjektet er gjennomført, eventuelt erstattes med annen spisskompetanse ved behov. IT-konsulentene går da rett inn i virksomhetenes kjerneprosesser, og de er viktige for at virksomhetene skal klare å holde tritt med den teknologiske utviklingen (Matusik \& Hill, 1998).

Lederne gir uttrykk for at de får tilgang til svært attraktive folk gjennom innleie. Lederne mener de dyktigste IT-folkene i markedet ikke ønsker noen «vanlig jobb», men foretrekker å være konsulenter. I et ordinært arbeidsforhold risikerer IT-konsulentene å bli «stuck» (innelåst, av bransjen kalt lock-in) med den IT-løsningen, i den versjonen denne virksomheten tilfeldigvis har anskaffet. En slik lock-in anses for de beste kandidatene som en karriererisiko. Deres egen kompetanse vil gradvis synke i verdi i en ordinær topartsrelasjon. Dersom konsulenter takker ja til en fast ansettelse hos en ordinær arbeidsgiver (ikke konsulentselskap), er det gjerne for å «roe litt ned», ifølge en av informantene. Ved at lederne selv leier inn slike folk som absolutt ikke har «roet ned», får de nyte godt av markedets heteste kompetanse, slik de selv oppfatter det.

\section{Økonomiske og beslutningsmessige rammer Økonomisk handlingsrom}

Flere av lederne legger vekt på fordelen med å kunne raskt nedskalere arbeidstokken ved behov. Deler av innsamlingen av data skjedde under 
koronakrisen, og noen informanter opplyste at det første de gjorde var å terminere kontrakter med innleide konsulenter før de begynte å vurdere permittering av egne ansatte. Rask nedskalering nevnes også som en generell fordel, særlig for de som opererer i bransjer med store markedssvinginger. Flere ledere påpeker også at det er enkelt å «bli kvitt» konsulenter som ikke fungerer faglig eller på andre måter. Kontraktene kan enkelt termineres med oppsigelsestid på en måned. Ofte kan en få til en utskifting raskere enn det også. Konsulentselskapet er ikke tjent med en misfornøyd kunde, og er villig til å strekke seg langt for å finne en løsning.

Flere ledere mener virksomheten burde bygget opp spesifikke IT-kompetanser selv. De viser hovedsakelig til tre årsaker til at det er vanskelig. For det første tar det ofte for lang tid å rekruttere egne ansatte. Når beslutning er tatt om et prosjekt har man ikke tid til å vente den tiden det tar å lyse ut stilling, intervjue, vente på kandidatens oppsigelsestid i gammel jobb osv. For det andre er utfallet av en ordinær ansettelsesprosess usikker. Det er vanskelig å konkurrere på lønn, særlig overfor kandidater som er konsulenter i nåværende jobb, men enda vanskeligere å konkurrere i arbeidsoppgaver. Det er med andre ord utfordrende å få ansatt de rette folkene med riktig kompetanse. Vi ser at flere ledere prøver å rekruttere innleide konsulenter de er fornøyd med, i tråd med tidligere funn (Ashford et al., 2007; Bastesen \& Nesheim, 2008).

Den tredje årsaken handler om ledernes økonomiske handlingsrom. Det er vanskelig å få gjennomslag hos innleiebedriften om flere fast ansatte. Budsjettprosesser og styringsprosesser er rigget slik at driftskostnadene skal holdes nede, og fast ansatte går på driftsbudsjettet. Konsulenter, derimot, er en prosjektkostnad, og prosjektkostnadene oppleves som langt enklere å utvide ved behov. Flere ledere er bekymret over dette, og omtaler det som å «pynte på tallene» på en slik måte at det skader virksomheten på lengre sikt. Konsulentene blir som nevnt ofte leid inn over lang tid, kanskje flere år. Virksomhetene bruker like store ressurser på å lære opp en konsulent, sette den inn i de virksomhetsspesifikke systemene, forståelse av fagområdet, arbeidsmetodikk, organisering osv. som de bruker på en vanlig ansatt. Når kontrakten går ut, forlater konsulenten virksomheten og går videre til neste oppdragstaker, og tar med seg 
kunnskapen ut. Flere ledere påpeker at den finansielle fleksibiliteten i for liten grad handler om muligheten til å omdisponere midler etter behov (Atkinson, 1984). Fleksibiliteten handler mest om muligheten til å justere prosjektkostnadene, ikke å kunne ansette ved behov.

\section{Fordeler og utfordringer med å leie inn IT-konsulenter}

\section{Forenklet styring}

Noen ledere trekker frem at en av fordelene med å lede konsulenter fremfor fast ansatte, er at man bruker mindre tid på administrativt arbeid som lønn, ferieplanlegging, sykemeldinger osv. En av våre informanter uttrykte det slik: «Det er mindre administrativt 'tjafs' med konsulenter». Flere peker på at det er enklere fordi de slipper personalansvaret. Ifølge Ashford et al. (2007) er en av grunnene til at mange ledere foretrekker å leie inn konsulenter nettopp at konsulentene er enklere å håndtere administrativt, men også politisk. Med politisk henvises det til organisatorisk støy, misnøye, streik osv. Risikoen for streik er mindre aktuell i en norsk sammenheng: selv om IT-ansatte ofte er organisert, er de i tariffområder der det sjelden forekommer streiker. Våre informanter la også lite vekt på misnøye- eller streike- aspektet. Noen sier likevel at det er lettere å «beordre» konsulentene, $\mathrm{og}$ at de er mer oppgaveorientert og lettere kan måles på resultat.

Noen ledere oppfatter konsulenter som «lettere å lede» og mer «selvstendige» enn fast ansatte, andre oppfatter at konsulentene trenger mer oppfølging enn de faste. Vi ser at dette varierer fra virksomhet til virksomhet, og ut ifra hvilke arbeidsoppgaver som utføres. Noen er tydelige på at konsulentene må settes godt inn i virksomheten, fagområdet og dens bransje for at de skal kunne forstå arbeidsoppgavene, mens i andre virksomheter skal de gjerne løse en teknisk utfordring hvor en ikke trenger inngående kunnskap om hverken organisasjonen eller bransjen.

\section{Konsulenter som kunnskaps- og beslutningsstøtte}

Lederes bruk av innleide konsulenter som kunnskapsstøtte, beslutningsstøtte og sparringspartner er lite omtalt i studier av alternative 
tilknytningsformer til arbeid. Dette kan være fordi forskningen om innleide konsulenter i mindre grad har vært sett fra et leder- og organisasjonsperspektiv (Ashford et al., 2007; Connelly \& Gallagher, 2004). En av lederne beskriver hvordan redselen for å virke inkompetent overfor kolleger gjør at lederen ber en konsulent om de viktige rådene, i stedet for å «dumme seg ut» på ledermøter eller overfor egne ansatte. Lederne er ofte selv fagpersoner som har fått lederansvar, men det er gjerne en stund siden de selv jobbet med teknologien. Likevel hadde flere av lederne en antagelse om at både de andre lederne og de ansatte forventet at de fortsatt er faglig kompetente. Siden de ikke er oppdatert lengre, er de dermed redde for å «tape ansikt» overfor medarbeidere og andre ledere, og derfor går de til konsulentene. Flere ledere er svært bevisste på faren ved å selv ikke å ha oppdatert kompetanse - de frykter at de ufrivillig outsourcer kompetanse om kjernevirksomheten til konsulenter.

Andre legger vekt på konsulentenes funksjon som utenforstående, som kunnskapsnomader og sparringspartnere. Konsulentene oppleves ofte som en nøytral tredjepart som ikke har virksomhetens historie, kultur og politiske prosesser den trenger å ta hensyn til eller er farget av. Det gjør at konsulentene kan representere et mer nøytralt syn i diskusjoner. Videre har de erfaring fra mange ulike kunder som gjør at de har med seg erfaringer fra hva andre har gjort, hva som har fungert og ikke fungert, samt nye ideer. Noen ledere uttrykker bekymring for å havne i bestemte spor, og konsulentene kan bidra med nyanseringer og nye ideer i diskusjonene. En konsulent uttalte at det er ikke bare konsulentens kunnskap man leier inn, men kunnskapen til konsulenthuset, i dette tilfellet et av verdens største og mest anerkjente innenfor IT-støttet utvikling av forretningsprosesser:

Når vi leier inn en konsulent fra [konsulenthus XX], så får jo vi hele [konsulenthuset] sin know-how med på kjøpet. Det gjør at konsulenten kan ta med problemet bak til [konsulenthuset] og få hjelp og innspill derfra og innhente den kompetansen. Vi kjøper kunnskapen konsulentselskapet besitter.

Det må likevel poengteres at det er stor variasjon i lederes bruk av konsulenter som beslutningsstøtte. Noen ledere er veldig bevisste på at konsulentene ikke skal brukes som rådgivere på denne måten. De er redde for at 
konsulentene skal komme for nært de strategiske beslutningene, som vi utdyper nærmere i neste avsnitt. Dette begrunnes med at de er redde for å dele sensitive bedriftshemmeligheter, samt at konsulentene kan påvirke dem $\mathrm{i}$ en bestemt retning som er gunstig for konsulentselskapet, mer en $n$ for dem som kunde. Det som i første omgang oppleves som en positiv kunnskapsoverføring, som i sitatet ovenfor, kan i neste omgang oppleves som å miste eget strategisk grep. Som kunde kan man bli for avhengig av en bestemt konsulentleverandør i markedet, og dennes motiv er å selge flest mulig timer på kort og lang sikt.

\section{Faren for å miste strategisk grep}

Flere ledere er bekymret over at konsulentene får for mye makt over virksomhetens strategiske veivalg. De er seg bevisst at konsulentene har en «egen arbeidsgiver» som selvfølgelig er interessert i mersalg. Dersom konsulentene klarer å vri beslutningene i konsulentselskapets eller egen favør, kan vi betegne det som opportunistisk atferd (Williamson, 1975, 1985). Dermed kan lederne, fordi de selv har mindre kompetanse, ende med den nest beste løsningen. Dette er en bekymring hos flere av lederne, mens konsulentene ikke nevner dette i noen særlig grad. En av lederne forklarer at hen er nødt til å ta noen «ukoselige samtaler» og være svært direkte ved å spørre om motivene for ulike løsningsforslag. Det bekymrer lederne at de «outsourcer» viktige beslutninger om løsningsvalg, fordi de mangler kompetanse til å ettergå konsulentenes forslag. For flere av informantene i vår studie var dette et av hovedproblemene med å bruke innleide konsulenter: Deres store frykt var å miste styringen over egen organisasjon og viktige beslutninger mht. løsninger og leveranser, fordi konsulentene var de med størst kompetanse på området.

Enkelte ledere med høy IT- og digitaliseringskompetanse påpekte at å gi fra seg denne styringen er en klassisk feil andre ledere gjør. Med riktig kompetanse og erfaring kan de styre konsulentene, istedenfor å selv bli styrt. De peker da på at risikoen for unødvendig binding til konsulenthus gjør at høy IT- og digitaliseringskompetanse trengs i store deler av organisasjonen. Ledere med resultatansvar, men uten slik kompetanse, kan fort bli bondefanget. Konsulenter kan for eksempel foreslå løsninger 
med mye koding, altså egen-utvikling, noe som vil medføre store, langsiktige innleie-kostnader for å drifte det samme systemet, kanskje over flere tiår. Det blir påpekt at de aller fleste konsulenthus har partnerskap. eller representerer visse programleverandører. Konsulenten vil da foreslå løsninger som gir mersalg både av produkter og timer. En av disse informantene sa at konsulenter er vår tids "parasitter", altså organismer som snylter på vertsorganismen. Metaforen ble brukt for å forklare hvordan lederne opplever at konsulentene nærmest suger seg fast som høytfakturerende leverandører uten at kundene har mulighet for å komme seg løs. En annen mente at nettopp dette fenomenet gjør at IT-kompetanse er viktig i enhver direktørstilling, også for områder som tilsynelatende ikke har så mye med IT å gjøre.

Matusik og Hill (1998) skiller mellom «component» og «architectual» knowledge, altså delkompetanse og arkitektur- eller prosesskompetanse. Delkunnskap handler om kunnskap om et spesifikt område, mens arkitekturkompetanse handler om de helhetlige prosessene og hvordan de fungerer sammen. Prosesskompetanse kan også kalles verdikjedekunnskap. Lederne ønsker at konsulentene har delkunnskapen, som de kommer inn med akkurat når den trengs, mens prosesskunnskapen bør eies av egne ansatte. De poengterer at slik er det ofte ikke - konsulentene får også prosesskunnskap som oppleves som svært bedriftsspesifikk. Faren ved dette er først og fremst ikke kunnskapslekkasje til konkurrenter, men at man mister grep om egne strategiske beslutninger.

Nesheim et al. (2014) finner i sin studie at utvalget var delt i sin opplevelse av opportunistisk atferd. Noen opplevde dette, andre ikke. Dette samsvarer med våre funn. Noen ledere var mindre bekymret over å miste selvstendighet i sine strategiske beslutninger, rett og slett fordi de ikke slapp konsulentene til i de strategiske diskusjonene. De var opptatt av å «holde en armlengdes avstand» til konsulentene og beholde styringen selv. Flere opplevde konsulentene også som veldig profesjonelle og lojale til oppdragsgiver. Mange konsulenter jobbet for kunden i flere år, og hadde en høy tillitsrelasjon. Samtidig påpekte de at det var lettere å unngå slik opportunistisk atferd dersom det var få konsulenter inne. Dersom konsulentene var tungt inne i prosjekter og gjerne var i flertall, var det lettere å miste kontrollen over den strategiske retningen. 


\section{Faren for kunnskapslekkasje}

Ingen av lederne frykter at konsulentene vil ta med seg kunnskapen om virksomhetens svakheter til konkurrenter. Noen ledere sier riktignok at de «må bare» stole på dem, de har ikke noe valg. Men det ser ut som tilliten til at konsulenten ikke tar sensitiv informasjon videre til konkurrenter, er helt reell. Konsulentene selv virker svært på bevisst på at de bygger opp bransjekunnskap og systemkunnskap fra kunde til kunde, men at de er helt avhengige av sitt renommé som pålitelige. Konsulentenes rolleforståelse og avhengighet av et godt renommé i markedet bidrar derfor til at de kan gis tillit fra innleiebedriften.

Grensene for hva slags informasjon som kan eller ikke kan bringes videre til andre kunder er hårfine, uten at hverken ledere eller konsulenter opplever dette som et stort problem. Noen mener det er helt uproblematisk at konsulentene lekker kunnskap fra deres virksomhet til andre virksomheter, og kaller situasjonen for «vinn-vinn». Dette fordi de får gode forslag og kompetanse fra konsulentens arbeid fra andre kunder. Ifølge leder for et av konsulentselskapene kan konsulentene dele generalistkompetanse, men ikke spesialkompetanse, og særlig ikke kunnskap som kan knyttes til bedriftshemmeligheter og konkurransefortrinn.

En fordel, som flere trekker frem, er konsulentenes viktige rolle som nettverksaktør som knytter ulike aktører sammen. En leder benevnte konsulentene som "gode bindeledd som har gitt oss nye kontakter og et godt nettverk». Lederen for konsulentselskapet mente det var en viktig oppgave for konsulentselskaper å koble sammen kunder med andre selskaper eller andre konsulentselskaper. Slik sett blir konsulentselskapene sittende i et kunnskaps- og informasjonsknutepunkt som ifølge Simmel (1923, referert i Burt, 1992, s. 30) er en verdifull posisjon. Han kaller det for «den tredjes gevinst» - «the third who benefits». Denne rollen trekkes frem som noe positivt fra kundenes ståsted også, da de har behov for disse nettverkene for å skaffe seg informasjon, kunnskap og ideer. Abelia, NHOs landsorganisasjon for blant annet konsulentselskaper, kaller konsulenter for pollinatorer i sin rapport om rådgiverbransjen (Wifstad et al., 2017), et uttrykk som også brukes i internasjonal litteratur om konsulenter. 


\section{Konklusjon}

Artikkelen undersøker lederes motiver for å bruke IT-konsulenter og bygger på 22 intervjuer med ledere i mellomstore og store virksomheter, IT-konsulenter, og leder for et konsulentselskap. Resultatene bekrefter tidligere forskning, som viser at tilgangen til oppdatert spisskompetanse er den grunnleggende drivkraften for å leie inn konsulenter. Videre peker lederne på at interne styringssystemer og langsiktige utsikter i egen bransje gjør det lettere å få godkjent innleie av konsulenter, enn å få godkjent ordinære ansettelser for å skaffe samme type kompetanse. Våre funn indikerer også at lederne opplever forenklet styring av kompetanse ved innleide i forhold til fast ansatte. Denne forenklede styringen innebærer blant annet å kunne inngå og terminere kontrakter på kort varsel, samt mindre administrativt arbeid med konsulentene. Kundene finner også tilgang til viktig beslutningsstøtte hos konsulenter. Kundenes bekymringer handler i liten grad om kunnskapslekkasje, men i større grad om å miste styringen over egne strategiske beslutninger fordi de mangler kompetanse til å vurdere konsulentenes forslag til løsninger. Det siste momentet er lite dokumentert i tidligere forskning.

Oppsummert viser vår undersøkelse en nokså likeartet beskrivelse av konsulentbruken hos informantene, til tross for at virksomhetene er svært forskjellige. Selv om beskrivelsen av behovet og løsningen er nokså lik, varierer beskrivelsen av opplevelsen: Mens noen ledere mener konsulentene er en nødvendig innsatsfaktor for å få gjort jobben, en form for frelse for å nå kravene, fremhever andre faren for å bli tatt over av parasitter som det dominerende situasjonsbildet. De som er mest opptatt av det siste perspektivet peker på at manglende IT- og digitaliseringskompetanse i eget hus kan koste virksomhetene dyrt.

Dikotomien «frelser» eller "parasitt» innebærer også et mulig paradoks: Jo mer konsulentene fremstår som «frelsere», altså bærere av den helt nødendige kompetansen for å få gjennomført et prosjekt, desto større er risikoen for at de samme konsulentene oppleves som «parasitter» over tid. Jo mer uunværlig og unik kompetanse som tilbys, jo lettere går man inn på valg som er uheldige på lang sikt. Flere ledere fremhevet at det er en voksende bevissthet i både næringslivet og i offentlig sektor om 180 
nødvendigheten av høy digital kompetanse hos lederne som innkjøpere, for å unngå nettopp den situasjonen.

\section{Forslag til videre forskning}

Vi har sett på høykompetent innleid arbeidskraft med IT-kompetanse. Det vil være interessant å undersøke om de samme fenomenene også gjelder for annen type høykompetent innleid arbeidskraft, slik som strategi-, økonomi, annen teknisk kompetanse m.m. Er sondringen mellom å være virksomhetens redning eller parasitt like relevant da, eller er det spesifikt for IT/digitaliseringsprosjekter?

Vårt datagrunnlag er hentet fra både privat og offentlig sektor. Vi antar at det sterke stillingsvernet i statlig sektor kan bidra til at lederne i stor grad tilpasser arbeidsoppgavene til den ansattes kapasitet, interesser og kompetanse. Det er samtidig stort behov for og bruk av innleide konsulenter med skreddersydd kompetanse. Det vil være interessant å studere i hvilken grad kunder i statlig sektor har styring over omfanget og varighet av leveransen, sammenlignet med privat sektor. Stadige medieoppslag om konsulentbruk uten styring i staten, samt Riksrevisjonens rapport (2017) om det samme, tilsier mer forskning om ledernes motiver for konsulentbruk nettopp i statlig sektor.

Vi har i denne studien intervjuet ledere fra små, mellomstore og store virksomheter. Flere informanter peker på de store bankene, og særlig DNB, som et eksempel på hvordan man kan bruke IT-konsulenter i stort omfang uten å miste grepet om egen digital forretningsstrategi. Er det da størrelsen som gjør at virksomheter som DNB ikke blir «fanget» av konsulentene, eller er det kompetansen internt i organisasjonen?

Det rent kontraktuelle i bruken av IT-konsulenter hadde også vært interessant å undersøke. Det er trolig gråsoner mellom innleie og entreprise, med ulik grad av bindinger til partnere på produktsiden. Ulike typer kontrakter vil ha ulike forretningsmessige konsekvenser for kunden. Kunnskap om dette vil gjøre det lettere å vurdere konsulentbruken i henhold til Atkinsons (1984) modell for fleksibilitet, og for eventuelt å utvikle modellen videre. 


\section{Takk}

Vi vil rette en stor takk til Anniken Overgaard og Martine Pedersen for hjelp til innsamling og transkribering av data i den innledende studien. De har brukt andre deler av datamaterialet i sin egen masterutredning. Forfatterne av denne artikkelen har foretatt egne kodinger og systematiseringer av studentenes transkriberte intervjuer. Vi vil også rette en takk til fagfelle for nyttige tilbakemeldinger, og redaktørene for konstruktive innspill på en tidligere versjon av kapittelet.

\section{Referanser}

Anand, N. \& Daft, R. L. (2007). What is the right organization design? Organizational Dynamics, 36(4), 329-344. https://doi.org/10.1016/j.orgdyn.2007.06.001

Andreassen, R. S., Ryberg, K., Grotle, H. R., Slettum, F. K. \& Nesheim, T. (2014). Menneskelige ressurser i oppstartfasen - Kompetansebehov og tilknytningsformer for arbeid i entreprenørbedrifter. Beta, 28(2), 136-153. Hentet fra http://www.idunn. no/beta/2014/o2/menneskelige_ressurser_ioppstartfasen_-_kompetansebehov_og

Ashford, S. J., George, E. \& Blatt, R. (2007). Old assumptions, new work: The opportunities and challenges of research on nonstandard employment. Academy of Management Annals, 1, 65-117. https://doi.org/10.1080/078559807

Atkinson, J. (1984). Flexibility, uncertainty and manpower management (Rapport 89, opptrykk). Institute of Manpower Studies. Hentet fra https://www.employmentstudies.co.uk/system/files/resources/files/89.pdf

Barley, S. R. \& Kunda, G. (2004). Gurus, hired guns and warm bodies: Itinerant experts in a knowledge economy. New Jersey: Princeton University Press.

Bastesen, J. \& Nesheim, T. (2008). Bemanningsutfordringer i oppstartfasen: Fra idealistisk kunstnerverksted til formell organisasjon. Beta, 22(2), 39-55. Hentet fra https://www.idunn.no/beta/2008/o2/bemanningsutfordringer_i_oppstartsfasen_ fra_idealistisk_kunstnerverksted_ti

Burt, R. S. (1992). Structural holes. The social structure of competition. Harvard: Harvard University Press.

Connelly, C. E. \& Gallagher, D. G. (2004). Emerging trends in contingent work research. Journal of Management, 30(6), 959-983. https://doi.org/10.1016/j.jm. 2004.06.008

Cook, T. D. \& Campbell, D. T. (1979). Quasi-experimentation. Design and analysis issues for field settings. Boston: Houghton Mifflin Company.

Eisenhardt, K. M. (1989). Building theories from case study research. Academy of Management Review, 14(4), 532-550. https://doi.org/10.5465/AMR.1989.4308385 
Eldring, L. \& Ørjasæter, E. (2018). Løsarbeidersamfunnet. Oslo: Cappelen Damm Akademisk.

Eurofond. (2017). Aspects of non-standard employment in Europe. Hentet fra https:// www.eurofound.europa.eu/publications/customised-report/2017/aspects-of-nonstandard-employment-in-europe

Johannesen, A., Tufte, P. A. \& Christoffersen, L. (2016). Introduksjon til samfunnsvitenskapelig metode (5. utg.). Oslo: Abstrakt forlag.

Kalleberg, A. L. (2000). Nonstandard employment relations: Part-time, temporary and contract work. Annual Review of Sociology, 26(1), 341-365. https://doi. org/10.1146/annurev.soc.26.1.341

Kalleberg, A. L. (2018). Precarious lives: Jobinsecurity and well-being in rich democracies. Cambridge, UK: Polity Press.

Kalleberg, A. L. \& Vallas, S. P. (2018). Probing precarious work: Theory, research and politics. I A. L. Kalleberg \& S. P. Vallas (Red.), Precarious work: Causes, characteristics, and consequences (Bd. 31, Research in the sociology of work). Bingley: Emerald Group Publishing.

Kinnie, N. \& Swart, J. (2020). Cross-boundary working: Implications for HRM theory, methods, and practice. Human Resource Management Journal, 30(1), 86-99. https://doi.org/10.1111/1748-8583.12239

Klenke, K. (2008). Qualitative research in the study of leadership. Bingley: Emerald Group Publishing.

Kunda, G., Barley, S. R. \& Evans, J. (2002). Why do contractors contract? The experience of highly skilled technical professionals in a contingent labor market. ILR Review, 55(2), 234-261. https://doi.org/10.1177/001979390205500203

Lepak, D. P. \& Snell, S. A. (1999). The human resource architecture: Toward a theory of human capital allocation and development. Academy of Management Review, 24(1), 31-48. https://doi.org/10.5465/amr.1999.1580439

Matusik, S. F. \& Hill, C. W. L. (1998). The utilization of contingent work, knowledge creation, and competitive advantage. Academy of Management Review, 23(4), 680-697. https://doi.org/10.5465/amr.1998.1255633

Nesheim, T. (2009). Mot et paradigmeskifte i forståelsen av arbeid og organisasjon? Sosiologisk tidsskrift, 17(1), 71-81. Hentet fra http://www.idunn.no/st/2009/o1/ mot_et_paradigmeskifte_i_forstaelsen_av_arbeid_og_organisasjon

Nesheim, T. (2016). Fast ansettelse eller løsere kobling til virksomheten? I A. Mikkelsen \& T. Laudal (Red.), Strategisk HRM 1. Ledelse, organisasjon, strategi og regulering (2. utg., s. 272-295). Oslo: Cappelen Damm Akademisk.

Nesheim, T., Fahle, B. \& Tobiassen, A. E. (2014). When external consultants work on internal projects. Exploring managerial challenges. I B. A. S. Koene, N. Galais \& C. Garsten (Red.), Management and organization of temporary agency work (Kap. 5). New York: Routledge. https://doi.org/10.4324/9781315815831 
Nesheim, T., Olsen, K. M. \& Kalleberg, A. L. (2007). Externalizing the core: Firms' use of employment intermediaries in the information and communication technology industries. Human Resource Management, 46(2), 247-264. https://doi. org/10.1002/hrm.20159

Olsen, K. M. (2016). The power of workers: Knowledge work and the power balance in Scandinavian countries. Employee Relations, 38(3), 390-405. https://doi.org/ 10.1108/ER-10-2014-0121

Pfeffer, J. \& Baron, J. N. (1988). Taking the workers back out: Recent trends in the structuring of employment. Research in Organizational Behavior, 10, 257-303.

Riksrevisjonen. (2017). Riksrevisjonens undersøkelse av konsulentbruk i staten (Dokument 3:6). Hentet fra https://www.stortinget.no/globalassets/pdf/ dokumentserien/2016-2017/dok-3-6-2016-2017.pdf

Roverud, L. H., Kjølvik, T. K., Nesheim, T. \& Jesnes, K. (2017). Mellomledd i oppdragsmarkedet. Søkelys på arbeidslivet, 34(3), 199-215. https://doi.org/10.18261/ issn.1504-7989-2017-03-04

Stake, R. E. (2000). Case studies. I I. N. Denzin \& Y. S. Lincoln (Red.), Handbook of qualitative research (2. utg., s. 435-454). London: Sage.

Standing, G. (2011). The precariat: The new dangerous class. London: Bloomsbury Academic.

Standing, G. (2014). The precariat. Contexts, 13(4), 10-12. https://doi. org/10.1177/1536504214558209

Wifstad, K., Stokke, O. M. \& Skogli, E. (2017). Verdien av gode råd - rådgivernceringens størrelse og betydning $i$ Norge (Rapport. Menon-publikasjon 64/2017). Hentet fra https://www.abelia.no/contentassets/446f39c1862e4cdd947b187293d6abc9/verdienav-gode-rad-menon.pdf

Williamson, O. E. (1975). Markets and hierarchies: Analysis and antitrust implications. New York: Free Press.

Williamson, O. E. (1985). The economic institutions ofcapitalism. Firms, markets, relational contracting. New York: Free Press.

Yin, R. K. (2014). Case study research. Design and methods (5. utg.). Thousand Oaks: Sage. 


\title{
Forgrønning av motorsport
} gjennom innovativ eventledelse. En casestudie av Zürich E Prix 2018

\author{
Hans Erik Næss \\ Hoyskolen Kristiania

\section{Rune Bjerke} \\ Hoyskolen Kristiania
}

\begin{abstract}
This chapter argues that event management and co-creation of green values require a different approach to and evaluative criteria for success than traditional ones. To substantiate this claim we turn to motorsports, which in relation to green values traditionally has been an adversary. With the advent of Formula E, a world championship for all-electric racing cars looking like those in Formula 1, this relation has been changed. Since its inauguration in 2014, the championship has continuously operationalized its vision of combining door-to-door racing with eco-friendly technology. One of the solutions has been to rethink event organization when hosting races, racing only in cities to reduce the ecological footprint from participants, spectators, sponsors and the media. The effects of this strategy were confirmed in 2019 when Formula E became the only motorsport championship in the world to be granted ISO20121 certification. Part of the explanation was that the urban localization of races makes it possible to integrate event offerings (e.g. partnership with universities, investor celebrities like Leonardo DiCaprio, and entrepreneurs like Elon Musk) with the championship's aim of contributing to smart city development and a green shift. Based on a qualitative case study of the 2018 Zürich E Prix, the Swiss Formula E event, this chapter therefore introduces lessons for event managers on how to combine the characteristics of track-based racing, commercial requirements, and urban development.
\end{abstract}

Keywords: event management, co-creation, motorsports, sustainability, organizational innovation

Sitering av denne artikkelen: Næss, H. E. \& Bjerke, R. (2020). Forgrønning av motorsport gjennom innovativ eventledelse. En casestudie av Zürich E Prix 2018. I J. Bastesen, B. K. Lange, H. E. Næss \& A. N. Thon (Red.), Ledelse av mennesker i det nye arbeidslivet (Kap. 7, s. 185-206). Oslo: Cappelen Damm Akademisk. https://doi.org/10.23865/noasp.118.ch7

Lisens: CC-BY 4.o. 


\section{Introduksjon}

I boken Organisasjon og lederskap i idretten (Hanstad, 2019, s. 244) siteres en toppleder for ungdoms-OL på Lillehammer i 2016 på følgende tenkemåte forut for arrangementet: «Jeg er jo sivilingeniør som liker tall og at det liksom skal være to streker under svaret.» Visjoner og verdier, derimot, hadde han lite til overs for, eller som han tenkte at det var: «Bullshit.» Likevel slapp han ikke unna verdigrunnlaget for en vellykket arrangementsgjennomføring, og forsto etter hvert også hensikten. Det skulle vise seg at de myke sidene ved arrangementsledelse - fra intern kultivering av fellesskap til relasjonsbygging med eksterne interessenter - var vel så viktig for å sikre et vellykket arrangement (Hanstad, 2019, s. 245).

Denne topplederens erkjennelse av at ikke-finansielle kriterier er særdeles viktige for et vellykket event er en viktig lærdom som vi ønsker å videreutvikle i dette kapitlet. Til tross for at vår case og ungdoms-OL har ulike målgrupper, organisasjonsstrukturer og lederkrav, handler det $\mathrm{i}$ bunn og grunn om det samme: å skape en god opplevelse for de som jobber i arrangementsorganisasjonen, deltagere, tilskuere og eksterne parter. Ifølge Kristiansen, Dille og Solem (2019, s. 12-13; se også Bjerke, 2016, 2019) representerer eventer en spesiell begivenhet eller hendelse av midlertidig varighet, der tre temaer knyttes sammen i gjennomføringen av det: 1) kompleksitet, prosjektledelse og interessenter; 2) kunnskap, læring og erfaring; 3) eventpolitikk, samskaping og opplevelser. Vår påstand, med støtte hos Batuev og Robinson (2019), er at det å forene disse tre temaene blir mye vanskeligere dersom eventets plass i en større samfunnsformasjon ikke ivaretas i ledelsen av det.

For motorsport generelt er dette en utfordring dersom vi inkluderer andre verdier enn de økonomiske. Grunnen er at den har vært dårlig på å håndtere politiske dilemmaer, bærekraftspørsmål, og likestillingsperspektiver (Næss, 2020a; 2020b). Løsningen fra Fédération Internationale de l'Automobile (FIA, det internasjonale motorsportforbundet), var å akkreditere Formel E - som av utseende ligner på Formel 1 - som det første helelektriske verdensmesterskap i baneracing frem til 2039. Formel E ble etablert av den spanske forretningsmannen Alejandro Agag i 2012, går over to kalenderår (fra høst til sommer) og består av 12-14 løp over hele verden, som alle foregår i bystrøk. Fra begynnelsen av har Formula 
E Ltd., eieren av mesterskapet, lagt vekt på tre elementer. Det første er teknologisk innovasjon. Bilene representerer fabrikantenes siste nytt på el-bilfronten, så som fra Porsche, BMW, Audi og Jaguar. Det andre er bærekraft. Det ble demonstrert da løpet i 2019, som det eneste racingmesterskapet i verden, fikk ISO20121-sertifisering; en internasjonal målestandard for bærekraftige arrangementer. Det tredje er urban utvikling. I tillegg til å arrangere løpene i kun bystrøk, er det et premiss at beslektede aktører deltar i gjennomføringen, så som tekniske høyskoler og lokalt næringsliv (Wilbaut, 2015).

Vår casestudie er Formel E-løpet i Zürich i 2018, som huset 160000 tilskuere og fikk gode tilbakemeldinger fra lokale myndigheter i Zürich by, publikum og media (Burgt \& Kalinauckas, 2018). Casen er derfor godt egnet for å forstå samvirkningen av sportslige hensyn og fingerspissfølelse for den samfunnsmessige konteksten eventet arrangeres i. Likevel har tidligere forskning på lignede arrangementer i England (Sturm, 2019) og erfaringene fra da det sveitsiske Formel E-løpet ble flyttet til Bern, vist at Formel E ikke selger seg selv. Dette kapitlet skal derfor bruke en studie av Zürich E Prix, som løpet ble kalt, til å utvikle tre betingelser for innovativ arrangementsledelse. For å gjøre dette vil vi først introdusere tidligere forskning på eventledelse, idrettsarrangementer og grønne verdier, før vi går over på kapitlets metode- og datagrunnlag. I kapitlets nest siste del presenterer vi funn fra analysen av vår studie av Formel E knyttet opp mot Kristiansen, Dille og Solems tre event-temaer, før vi i konklusjonen redegjør for studiens begrensninger og overføringsverdi.

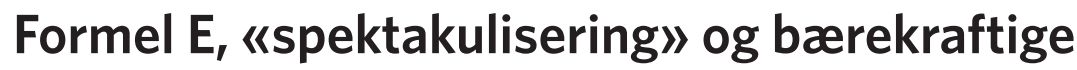 arrangementer}

Formel E-mesterskapet er et eksempel på hva Tomlinson og Young (2006) kaller «spektakuliseringen av sport». Begrepet henspiller på det at siden sommer-OL i Los Angeles 1984 har det blitt vært en treleddet endring i hvordan slike arrangementer organiseres, gjennomføres og promoteres. For det første har de blitt underholdningsknutepunkter, der konkurransen bare er et av flere aspekter oppmerksomheten kan rettes mot. For det andre har mediene formet (medialisert) arrangementet slik at det er 
bedre tilpasset sendeflater og kommunikasjonsteknologi. For det tredje har offentlige myndigheters rolle endret seg fra å være fasilitator til å bli en aktiv interessent $\mathrm{i}$ selve arrangementet. Underveis i denne perioden har «bærekraft» gått fra å være et ønske til et "policyinstrument». Basert på Howlett og Rayners forståelse av policyinstrument (2007) vil det si et strategisk insentiv fra Formel Es side for å endre atferd hos sine interessenter slik mesterskapets samfunnsansvarsmål kan nås.

Til tross for stor oppmerksomhet rundt Vår felles framtid, også kjent som Brundtland-rapporten fra 1987, ble bærekraft som mantra for ledelse av eventer likevel ikke særlig merkbart før på 1990-tallet. Selv med markant fokus på bærekraft i forbindelse med enkelteventer som vinter-OL på Lillehammer i 1994 og fotball-VM i Tyskland i 2006, forble det et marginalisert forskningsfelt til begynnelsen av 2010-tallet (Sotiriadou \& Hill, 2015). Heller ikke innen annen forskning på ledelse av eventer ble bærekraft en del av ordforrådet før på begynnelsen av 200o-tallet (Lawton, 2011). Ti år senere, i 2020, har dette endret seg radikalt. På den ene siden har eventledelsesforskning generelt oppdaget et stort mangfold av bærekraftforbedrende praksiser (Herstein \& Berger, 2013; Tölkes \& Butzmann, 2018). «Bærekraft» forstås videre nå langs alle tre dimensjonene fra Brundtland-kommisjonens rapport - sosialt, økonomisk og økologisk. På den annen side har idrettsarrangementer spesielt, delvis som følge av sponsorers økte oppmerksomhet på samfunnsansvar, begynt å systematisere sitt bærekraftarbeid. Samtidig er det fortsatte mangler ved dette arbeidet, også akademisk sett. I deres litteraturgjennomgang av forskningsartikler fra 2007-2017 konkluderte Trendafilova og McCullough (2018) med at de minst omtalte temaene var "performance evaluation» og «social sustainability».

Særlig det siste, samfunnsmessig bærekraft, anser vi som nyskapende hos arrangørene av Zürich E Prix, og det er det vi i fortsettelsen vil rette vår oppmerksomhet mot. Motorsport generelt har nemlig slitt med miljøprofil og samfunnsansvar de siste to tiårene (Mackellar \& Reis, 2014; Sturm, 2019; Tranter \& O'Keefee, 2004). Samtidig har studier vist at Formel E har blitt en kjæledegge for bilprodusenter og sponsorer med tro på teknologi som løsning på klimautfordringene (Næss, 2020a; Robeers, 2019). Dette viser seg i de økonomiske resultatene også: Selv om Formel E 
oppga et tap på €26,4 millioner i 2018, genererte det også en rekordinntekt for serien på €133,4 millioner - mest takket være økende sponsorinntekter og påmeldingsavgifter til løpene, og en forretningsmodell som mest av alt ligner en startup (Sylt, 2019). Samtidig er Formel E ingen enkel utvei fra bilfabrikantenes utfordring med å bruke motorsport til å fremme klimavennlige mobilitetsløsninger. Sturms (2019) casestudie av London E Prix 2015 viste at hva arrangørene så på som involverende interessenthåndtering, ikke stemte overens med synet fra byens organer for bevaring av naturlandskap.

Erfaringer fra eventevalueringer i sport spesielt tyder nemlig på at dersom ikke arrangørene ivaretar "den tredelte bunnlinja» som består av økonomi, miljø og sosiale hensyn (Dashper, Fletcher \& McCullough, 2014) vil dets legitimitet svekkes og eksponeres for unødvendig kritikk. Getz (2009, s. 68) skriver eksempelvis om eventer generelt at det å skape «social equity requires full integration of residents and other stakeholders in the decision-making process for bidding on, creating and marketing events, and in assessing their impacts». Smith (2009) var likeledes tidlig ute med å kritisere hvordan «den nyliberale ideologiens» grep om prosessen, der byer konkurrerer mot hverandre for idrettsarrangementer, kan drukne positive effekter fra arrangementet. For mens eventer skaper en midlertidig «feelgood»-faktor i form av positive holdninger til hva det har bidratt med, er den reelle «do-good»-faktoren (Smith, 2009) langt mer usikker - altså hva eventet faktisk har bidratt med i form av økonomisk vekst, sosial integrering og økologisk nytenkning. For å skape en slik «do-good»-faktor som Smith etterlyser, hevder vi at arrangørene må tenke nytt om tre ting relatert til sosial bærekraft: interessentinvolvering, normvurdering og kulturelle forutsetninger.

\section{Teoretisk rammeverk}

Interessentteori er velkjent innen organisasjons- og eventforskningen, og handler primært om å tilgodese alle involverte parter med muligheter til å utforme resultatet. Blant de mange teoriene om dette kan Mitchell, Agle og Wood (1997) sitt begrep om «interessentinnflytelse» (stakeholder salience) være relevant. Innflytelsen bestemmes av den samlede «skåren» 
en interessent får gjennom tre interessentdimensjoner - makt, legitimitet, og press - og dertil tilhørende kombinasjoner av disse. Andre har argumentert for tre endringer i denne modellen (Neville, Bell \& Whitwell, 2011). For det første er ikke innflytelse noe en interessent har eller ikke - det er et dynamisk forhold som dessuten kan endres underveis i arrangementet, dersom det går over lengre tid. For det andre er press ikke nødvendigvis så relevant for å identifisere de viktigste interessentene. For det tredje, og i våre øyne det viktigste, må legitimitet forstås mer presist for å utnyttes som verktøy for interessentinnflytelse. Som et resultat har vi fătt en ny definisjon av interessentbetydning:

Stakeholder salience is the prioritization of stakeholder claims by managers based on their perception of the degree of power of the stakeholder and the degree of moral legitimacy and urgency of the claim. (Neville et al., 2011, s. 369)

Riktignok er det langt fra enighet om at denne definisjonen favner interessentproblematikken bedre enn Mitchell et al. Men i sammenheng med vår casestudie kan den sies å være nyttig. Hovedårsaken er at hvis vi går et skritt videre, til normvurdering, så har arrangører en økende utfordring i det å skape harmoni mellom samfunnsnormer og eventnormer.

Sosiale normer er uformelle regler som organiserer samhandlingen $i$ et samfunn. Idretten er full av slike sosiale normer, og for å vise den bredere relevansen av dem i denne diskusjonen kan vi ta et eksempel utenfor Formel E. I 2016 var det brytninger mellom X Games i Oslo og Idretts-Norges forventninger til arrangørene. I brevet fra Norsk skiforbund (NSF) til blant andre Den internasjonale olympiske komité (IOC) og Det internasjonale anti-dopingbyrået (WADA), står det at NSFs støtte til arrangementet - og støtte til Oslo kommunes tilskudd på 42 millioner kroner til arrangementet - var betinget av deltagelse i antidopingarbeidet. ${ }^{1}$ Ettersom X Games ikke hadde noen slike antidopingbetingelser, var det duket for det som fremsto som en konflikt mellom verdier snarere enn hvem som skulle bestemme. Konflikt rundt denne moralske siden ved arrangementet, og som binder interessentinvolvering og normvurdering

1 En kopi av brevet kan leses her: https://www.skiforbundet.no/contentassets/fofo3f2d1fa844aa8b f9ff84229e77ac/brev-til-fis-ioc-wada_240216.pdf (lest 2. mars 2020). 
sammen, kunne vært unngått dersom Oslo kommune var bedre rustet til å se sammenhengene til de kulturelle forutsetningene for idrett i Norge. I våre øyne handlet ikke dette bare om dopingbestemmelsene, men at ekstremsport vil gjøre ting på sin egen måte. Da følges ikke alltid de vante sosiale normene for hvordan idrett skal utøves i Norge.

Betydningen av å forstå de kulturelle forutsetningene for disse normene har vist seg å påvirke pro-bærekraftig forbrukeratferd (Chen, 2010; Culiberg \& Elgaaid-Gambier, 2016). Samtidig er den forbrukerorienterte tilnærmingen til pro-bærekraftige holdninger eller atferd for smal til å påvirke sosiale normer i en medborgerskapskontekst. Under Zürich E Prix var det samarbeidet mellom forbrukere, beboere, sponsorer og offentlige representanter som gjorde at den selvsentrerte forbrukertilnærmingen måtte byttes ut med en bredere forståelse, ikke minst fordi sosiale normer går imot individuelle interesser som medlemmer av et samfunn. I en sosial norm ligger det en forventning om at vi samarbeider til fellesskapets beste, selv om det ikke nødvendigvis gagner oss som individer (for eksempel står vi i kø, selv om det tidsmessig lønner seg å snike). Dersom et event skal utnytte «medvinden» som kjennskap til sosiale normer gir dem, må de samtidig understøtte dette ved å praktisere innsikt i kulturelle forutsetninger for selve arrangementet. Samspillet med media er avgjørende her, ettersom sport gjennom den siste halvdelen av det tjuende århundret er blitt «medialisert» til å fungere som en referansekatalog av forskjeller mellom oss (hva er særegent med nordmenn) og de andre (alt det som nordmenn liksom ikke er) (Rowe, 1999).

I en bærekraftkontekst vil det si at hvis et arrangement skal profilere seg som «økologisk», er det fordelaktig å normalisere grønne verdier. Det er i alle fall argumentet fra Rettie, Burchell og Riley (2012), som bygger sin teori på at «forgrønning» (greening) ${ }^{2}$ vil skje mindre konfliktfylt dersom aktiviteter og produkter gradvis blir en del av hverdagen og mainstream-kulturen. Normalisering betyr altså ikke det samme som at alt skal bli likt, men at forgrønning blir noe annet enn et radikalt grep for å redde planeten eller bli forvekslet med «grønnvasking» (greenwashing)

2 Foruten å fornorske ordet «greening», henspiller «forgrønning» dessuten på ordet «greenfluencing», som først ble brukt av reklamebyrået Porter Novelli i 2008 (se Næss, 2020a). 
- noe som ifølge Næss (2020a) allerede er en overhengende fare for Formel E sine sponsorer. For studier av eventer generelt, og motorsporteventer spesielt, betyr det å operasjonalisere ansvarlig arrangementsledelse. Ifølge Maak (2007) krever dette at

[...] leaders need to build, and rely on, social capital, i.e., social structures and resources both, internal and external to the organization, which allow us to facilitate responsible action and which are inherent to more or less institutionalized relationships of mutual recognition. (Maak, 2007, s. 331, kursiv original)

Av særskilt interesse for eventarrangører er Maaks fremheving av sosial kapital. Selv om det er et særdeles velbrukt begrep i samfunnsvitenskapene, forenes bruken i høy grad av merverdien i det å skape sosiale nettverk: sosial kapital genereres når de samlede ressursene som ligger i det å ha tilgang på et nettverk av relasjoner blir etablert som en kilde til gjensidig samarbeid i en gruppe (eller, i negativ forstand, gjensidig fragmentering, av typen splitt-og-hersk) (Portes, 1998). For ansvarlig arrangementsledelse vil det si å bygge tillit mellom interessentene, slik at arrangementet bidrar til at den sosiale kapitalen i samfunnet styrkes. Uten tillit og etablerte relasjoner, risikerer man at interessentene splittes og den sosiale kapitalen synker. Derfor blir det et spørsmål om hva interessentene skal ha tillit til. Normaliseringen av grønne verdier er i denne sammenheng relevant å fokusere på, og selv om ikke dette er en tillitsstudie per se, blir et kjernepunkt den sveitsiske arrangementskomiteens evne til å kombinere sportslige interesser (fra deltagerteam, Formula E Ltd., sponsorer osv.) med samfunnsmessige interesser (interessentinvolvering, normvurdering og kulturelle forutsetninger).

\section{Metode og data}

Denne artikkelen er basert på en casestudie av Formel E der kildegrunnlaget er én nøkkelinformant samt sekundærdata tilknyttet casen. For å forklare dette metodevalget kan vi begynne med å referere til Yin (1994), som oppgir at casestudiemetoden er en empirisk undersøkelse av et samtidsfenomen. Dette fenomenet undersøkes i konkret kontekst med bruk av ulike kilder (s. 23). Da det finnes flere typer casestudier, er dette kapitlet 
basert på en instrumentell casestudie der selve casen eksemplifiserer det overordnede fenomenet (Stake, 200o, s. 437). Valget av Zürich E Prix 2018 var derfor et case-eksempel, det vil si noe som brukes for «clarification rather than for verification» (Kolyperas, Maglaras \& Sparks, 2018, s. 7). Dessuten var casevalget begrunnet $\mathrm{i}$ at det var en strategisk representant for Formel E, som igjen er eksempel på innovativ eventledelse. I selve gjennomføringen av undersøkelsen var to ledd av overordnet betydning.

Det første var kredibilitet, hvilket skapes gjennom å samle informasjon (data) fra ulike kilder og deretter sammenligne disse for å identifisere mønstre og kontraster (Shenton, 2004). Primærkilden var et kvalitativt intervju med en enkelt informant som var sentral i alle sider ved organiseringen av Zürich E Prix. Utsendt på vegne av arrangementskomiteen og den utvidede interessentgruppen, ble han representant for billøpets gjennomføring. Ulempene med å ha kun én informant er at denne personens subjektive meninger kan blandes med arrangementskomiteens vurderinger, en hullete hukommelse og "polerte svar». Disse ulempene ble imøtegått på flere måter. Først og fremst ser vi, som Mintzberg (1979, s. 582; se også March, Sproull \& Tamuz, 1991), ingen grunn til å unnskylde «samples of one». Såfremt den personen er villig til å dele sin kunnskap med oss på vegne av sin ekspertise og/eller sitt fellesskap, er kritikken mot manglende generaliserbarhet eller populasjonsrepresentativitet irrelevant for ikke-positivistisk forskning (Boddy, 2016). Det er heller ingen automatikk $\mathrm{i}$ at flere informanter gir et rikere datamateriale. Krause, Luzzini og Lawson (2018, s. 45) argumenterer med at det å ha flere informanter er mindre viktig enn å ha den rette informanten. Nøkkelinformanter kan sies å være personer som fungerer som portvoktere inn til et større fenomen, og uttaler seg på grunnlag av sin ekspertise (Kumar, Stern \& Anderson, 1993; McKenna \& Main, 2013). Medieuttalelser fra andre i arrangementskomiteen tyder videre på at vi neppe ville fått radikalt andre svar enn fra denne informanten.

Det andre var bekreftbarhet, eller hvorvidt studiens metodologiske veivalg er etterprøvbare (Edwards \& Skinner, 2009, s. 72). For å oppnå dette må forfatterne vise at forskningen var faktabasert, systematisk kodet og kategorisert etter analytiske prinsipper (Edwards \& Skinner, 2009, s. 72). For vår del var intervjuet en samtale basert på en guide med 
fire åpne spørsmål knyttet til planlegging, gjennomføring, samhandling og interessenthensyn, samt en rekke prober (oppfølgingsspørsmål). Innholdet fra intervjuet, samt andre kilder vi kommer tilbake til nedenfor, ble deretter tolket i lys av påstanden om at idrettsledelsetekster ofte er «kulturelt standardiserte diskurser assosiert med verdisystemet som en organisasjon vil fremheve» (Edwards \& Skinner, 2009, s. 114). For et kommersielt foretak som Formula $\mathrm{E}$ betydde det at vi gransket muligheten for PR-taktikkeri fra informanten og andre kilder. Kildetriangulering ble foretatt gjennom en rekke kontroller av hva denne informanten sa, ikke bare fordi vi ønsket et bredere informasjonsgrunnlag, men også fordi vi ønsket å vurdere nøkkelinformantens evne til å se eventet både fra et fugle- og froskeperspektiv samt å vurdere hvordan informanten svarte på henholdsvis fakta- og refleksjonsspørsmål (Lewis \& Ritchie, 2003; Krause, Luzzini \& Lawson, 2018). Hovedsakelig søkte vi derfor informasjon i sekundærkilder knyttet til Formula E og Zürich E Prix. Dette inkluderte i første rekke interessentnettsider, ${ }^{3}$ aviser, magasiner og motorsportrelaterte nyheter om eventet.

\section{Funn 1: Kompleksitet, prosjektledelse og interessenter}

Kompleksiteten i et event betinges av tre ting: antall interessenter og den relative betydningen av dem, prosjektledelsens samarbeidsformer, og evnen til å ta høyde for uforutsette hendelser. I lys av dette er det interessant at Zürich E Prix 2018 ble til som resultat av den sveitsiske byrådens fascinasjon for mesterskapets blanding av bærekraft, mindre investeringer i infrastruktur, og mer innsats på løpende prosjektledelse. Til forskjell fra et Formel 1-løp, som i hovedsak foregår på et selvstendig baneanlegg, er Formel E-løp basert på gateveier og midlertidige sperringer i en by. Byråden i Zürich ble derfor koordinator for en fem-persons gruppe på

3 http://www.fiaformulae.com/en (offisiell mesterskapsside), https://www.zuricheprix.ch/ (offisiell eventside), https://edays.ch/en/ (aktivitetsprogrammet tilknyttet eventet) og http://new.abb. $\mathrm{com} /$ news/detail/3182/abb-\&-formula-e-partner-to-write-the-future-of-e-mobility (den offisielle mesterskapssponsoren, med hovedkvarter i Zürich). 
vegne av arrangementets eier, Swiss E-Prix Operations AG, som på sin side fikk lisens fra Formula E Ltd. til å avholde den sportslige delen av arrangementet. Ifølge informanten fikk denne gruppen, som ble ledet av Pascal Derron (administrerende direktør i Swiss E-Prix Operations AG) et oppdrag fra byrådet om å gjennomføre arrangementet.

Samarbeidet fulgte en annen praksis enn i Formel 1. Der tilbyr den kommersielle rettighetseieren plasser i en løpskalender til høystbydende. Deretter fordeles ansvar og plikter når det gjelder event, mediedekning, inntekter og utgifter gjennom et ekstremt intrikat kontraktsopplegg. Formel E-løp utlyses også på anbud, men med vel så mye fokus på den tredelte bunnlinja som på kommersielle interesser. Ifølge informanten var denne gruppen for Zürich E Prix 2018 en «leverandør av ideer» til en grovskisse over arrangementet. Beslutninger ble deretter tatt fortløpende i samråd med nøkkelinteressenter. I denne prosessen fikk enkelte nøkkelinteressenter, som i første rekke besto av forgreninger fra den fem person lille gruppen, større innflytelse enn andre. Den sveitsiske banken Julius Baer, for eksempel, var ikke bare eventsponsor - den er også hovedsponsor for hele Formel E-mesterskapet. Dermed ble bankens meninger om hvordan arrangementet skulle finne sin plass i tilbudet av motorsporter ganske betydningsfulle for hele arrangements konsept om å markere et brudd med det bestående. I likhet med hvordan Zürich E Prix 2018 ble skissert med en tanke om å lage noe helt annet enn Formel 1, i form av merkevareprofil, allmenn tilgjengelighet og sammensetning av tilhørende aktiviteter, ønsket banken å tenke utelukkende fremover for sin egen del også.

En annen vurdering som ble gjort fra starten var å inkludere interessenter på en måte som fikk dem til å innse den gjensidige nytteverdien i det å delta (det omvendte av splitt og hersk). En nøkkelpartner var universitetet ETH Zürich, ranket blant topp 10 i verden over flere år, som gjorde det mulig for arrangørene å imøtekomme Formel Es krav om en «E-Village» i nærheten av løpstraseen. Selv om konseptet er bestemt fra Formel Es side, er det opp til arrangøren å fylle det med innhold. Mer lik en festival enn et billøp, hvor tivoliattraksjoner, paneldebatter og tekniske studentkonkurranser med støtte fra Tesla ble arrangert, antas det at over 100 ooo mennesker besøkte E-Village-området (Burgt \& 
Kalinauckas, 2018). Før E-Village og racingbanen ble bygget, ønsket imidlertid Swiss E-Prix Operations AG å sikre støtte fra beboere og næringsliv langs løpstraseen. En gruppe forskere fra ETZ Zürich foretok et halvt år før løpet en spørreundersøkelse som resulterte i at over halvparten av respondentene var positive til det, mens rundt en tredjedel var negative (Brückmann, Huber \& Bernauer, 2018). Pascal Derron (administrerende direktør i Swiss E-Prix Operations AG) tolket resultatene som et incentiv til å gjøre mer, og delte ut personlige invitasjoner til interessentene om å besøke Formel E-kontoret og få en guidet tur langs det som skulle bli banen. Informanten forteller at dette initiativet var en suksess: «Vi så for oss at noen hundre ville komme til det vi kalte 'pitlane walk' ${ }^{4}$ dagen før selve løpet - men så dukket det opp over 1400 personer. Jeg tror det var en fin måte å avmystifisere hva løpet handlet om, skape en buffer mot negativ energi, og kanskje motivere nye fans til å titte på løpet.»

\section{Funn 2: Kunnskap, læring og erfaring}

Arrangørene av Zürich E Prix tok oppfordringen fra Formula E Ltd. på alvor om at hvert event skal etterlate løpsområdet i bedre forfatning enn da de kom. Her nevner Formel E blant annet investeringer i infrastruktur og etableringer av bærekraftfremmende tiltak (Wilbaut, 2015, s. 47). Dette ble fulgt opp på en måte som gjenspeiler logikken fra det teoretiske perspektivet om normalisering av grønne verdier, forklart tidligere. Foruten å gå videre fra det begrensende i det å bare tilby nye produkter og alternativer som ledd i en forgrønningsprosess, handlet det om for arrangørene å skape en plattform for videre kunnskapsbygging. «Vi baserte eventet på en aktivitetsplattform vi kalte 'More than a race'», forteller informanten. «Byen ville ikke tilby oss bruken av offentlige gater dersom eventet hadde vært utelukkende kommersielt.» For å imøtekomme byens ønsker foreslo arrangementsgruppen to tiltak.

Det første var å «lure inn» grønne valg som en del av eventdesignet. Siden å spille på sosiale normer krever en sosial tilnærming til samhandling og

$4 \quad$ Pitlane er området ved siden av banen der bilene står før de skal ut å kjøre, eller kommer inn for å bli reparert. Ofte er det et VIP-område tilknyttet pitlane. 
kulturelle forutsetninger for «forgrønning», gikk arrangørene bort fra å påtvinge interessentene et personlig ansvar for miljøet som premiss for involvering i eventet. En slik individualiserende moralisme kan ifølge tidligere forskning hindre sosial innovasjon (Elgaaid-Gambier, Monnot \& Reniou, 2018; Rettie et al., 2012). Selv om bærekraftmotivet gjennomsyrer markedsmaterialet til både Formel E og Zürich E Prix, var operasjonaliseringen av det gjennom eDays (aktivitetsprogrammet tilknyttet eventet) lite aggressiv. For eksempel inngikk Swiss E-Prix Operations AG en avtale med myclimate.com, en idealistisk organisasjon med mål om å nøytralisere eventers $\mathrm{CO}_{2}$-utslipp, uten å omtale avtalen på egne nettsider.

I sammenheng med dette finner vi det andre tiltaket: kombinere logistisk nytenkning som en integrert del av eventet. På den måten kunne eventet markedsføres som et turistmål der det fulgte med kollektivfordeler - da en av partnerne var den føderale sveitsiske jernbanen (SBB)dersom man kjøpte papirløs billett til billøpet. Dessuten minimerte de VIP-tilbudene som ellers er vanlig for store motorsportevents og utnyttet byrommet til å skape åpne rom (både for de med og uten billett) der Formel E-universet kunne vektlegge ny kunnskap og praksis relatert til bærekraftige innovasjoner. I regi av eDays holdt FIA, ETZ Zürich og arrangementskomiteen en paneldebatt med deltagere som blant annet Nathan Borgford-Parnell fra FNs miljøvernprogram (UNEP). Et annet sted ble eDays Startup - en samling for gründere innenfor smarte byer, e-mobilitet og fornybar energi - arrangert i samarbeid med digitalswitzerland Market Entry Bootcamp, et veksthus for gründerbedrifter.

\section{Funn 3: Eventpolitikk, samskaping og opplevelser}

Til forskjell fra andre europeiske land har ikke Sveits en rik motorsporthistorie, som i mange tilfeller brukes som grunnlag for å tiltrekke seg nye sponsorer og interessenter. Årsaken er at motorsport generelt har en forkjærlighet for nostalgi knyttet til de tre dimensjonene ved sted (fysisk utforming, aktiviteter, og mening). Særlig gjelder dette de tre store: Indianapolis 500, Le Mans 24 de Heures og Monaco F1 Grand Prix (Næss, 2014; O’Kane, 2011). For Sveits er situasjonen en annen, siden baneracing 
har vært forbudt siden 1955. Dermed hadde de to valg: kopiere sine idoler, eller skape noe nytt. Siden fokuset lå på det siste ellers, satte arrangementskomiteen som premiss fra byens side at de utnyttet mulighetene i Formel E-løpet (noe som ville øke legitimiteten til eventet, men dette sa ikke informanten noe om). I lys av hva som har skjedd med arrangørene i 2019 og 2020, som vi kommer tilbake til nedenfor, anså også komiteen byrådet som det vi kan kalle en «kulturell garantist» for at eventet ville gjennomføres selv om det skulle oppsto uenighet mellom det tette nettverket av interessentene (byen løp ingen økonomisk risiko på grunn av bankens garantier).

Etter den første initieringsfasen foregikk prosjektet ifølge informanten nokså pragmatisk - ikke som følge av en spesifikk tilnærming eller grunnet visse ledelsesprinsipper, «men en samarbeidsform drevet av tidspress!». Likevel er det tydelig hvordan Zürich E Prix praktiserte det Schüßler, Grabher og Müller-Seitz (2015) mener kjennetegner innovative events: et åpent format med lav terskel for både å delta og å bidra til verdien av det (s. 168). Byen så på løpet som en mulighet til å fremme sosial interaksjon, i stedet for som en trussel mot dets indre liv. Likeledes så Swiss E-Prix Operations AG byens engasjement som en forutsetning for, i stedet for en inngripen i, sportens kjernevirksomhet. Formel Es administrerende direktør, Alejandro Agag, skrev senere at denne typen integrerte formål var det som skilte Zürich E Prix fra andre formelbaserte billøp:

It's exactly the thing we want to do in Formula $\mathrm{E}$ - take the race to the people and make it part of the city. People sunbathing on the shores of Lake Zurich were not there because of the race; they were there enjoying their weekend while the race was going on too. The Formula E race was part of the city life. (Agag, 2018)

Vår tolkning av dette samarbeidet er at det bunnet i en forståelse av Zürich E Prix som en offentlig opplevelse forent i teknologi, bærekraft og action, ikke bare en forbruksvare for spesielt motorsportinteresserte. Tilknyttet dette var Formel Es underliggende målgruppefokus på Generasjon Y (Wilbaut, 2015, s. 26), og ideen om å tiltrekke seg mennesker utenfor den tradisjonelle typologien av motorsportinteresserte (se Næss, 
2014, kap. 6). Fokuset på samskaping gjenspeiler derfor et annet funn fra Twynam og Johnston (2004), som dokumenterte at det er mulig å forme innbyggernes syn på et event ved å være lydhør for deres innspill og samtidig tilby dem noe nytt med tanke på det vi tidligere refererte til som do-good-faktorer (Smith, 2009).

\section{Konklusjon: Tre betingelser for innovative eventledelse}

Vi skrev innledningsvis at Zürich E Prix var en suksess etter mange målestokker. Likevel er det ingen garanti for gjentagelse. Året etter, i 2019, ble den sveitsiske runden av Formel E- mesterskapet flyttet til Bern på grunn av at datoene for arrangementet havnet på et svært tradisjonelt event i Zürich. I den nye settingen havnet Swiss E-Prix Operations AG i konflikt med flere interessenter, selv om ledelsesprinsippene var de samme som i Zürich. Kilder peker på ulike årsaker til dette - eksempelvis høyere utgifter til sikkerhetstiltak, mindre smidig samarbeid med kantonen (deriblant strid om en ubetalt regning etter vandalisme), og politisk kritikk av et arrangement de mente «grønnvasket» en forurensingsindustri (Cronin, 2019; Hilzinger, 2020). I januar 2020 gikk derfor Swiss E-Prix Operations AG konkurs (Swissinfo, 2020). Omtrent samtidig ble et nytt selskap, Swiss E-Prix GmbH, etablert av de samme folkene med sikte på å arrangere fremtidige Formel E-løp i Sveits.

I våre øyne er den overordnede lærdommen fra denne utviklingen følgende: byen må ha større kulturelt eierskap til arrangementet. Der vår informant pekte på at lokale myndigheter i Zürich så på Formel E-løpet som et kulturelt tilskudd til byutviklingen og baserte interessentsamhandling på det, tilnærmet Bern seg arrangementet som et verktøy for å øke turismen, bedre byens image, og skape økonomiske ringvirkninger (Bern, 2019). Selv om sistnevnte tilnærming er velkommen i Formel Es forretningsmodell, er «byen» en såpass sammensatt interessent at den ikke kan behandles som om den har samme type motiver for involvering som sponsorer, media eller deltagere. Dette leder oss til å konkludere med at casestudiet av Zürich E Prix 2018 har produsert tre betingelser for innovativ eventledelse. 
Den første betingelsen er å innse betydningen av sosial kapital. Ledergruppen i et event vil tjene på å integrere verdier og kulturelle forutsetninger i et større samfunnsperspektiv som grunnlag for prosjektarbeidet snarere enn å behandle det som et resultatmål. Det at ledelsen for eventet er ute blant folk og snakker med dem, og gjør sitt for å få dem til å føle eierskap til det som skal skje, krever imidlertid innsikt i hva folk flest kan være bekymret for. Spørreundersøkelser kan avdekke noe av dette. Men erfaringene fra Zürich E-Prix viser at det ligger en mer mellommenneskelig verdi i det å invitere beboere og sponsorer i prosjektplanleggingen. Da kan de med egne øyne se hva de har felles, eller hva som skiller dem, for å skape tillit til arrangementets bidrag til byen de bor i. Denne måten å generere sosial kapital på er avgjørende for at eventet skal ha verdi utover det rent finansielle.

Den andre betingelsen for innovativ eventledelse er å forstå hvordan sosial bærekraft er noe annet enn det å pynte byen med symboler fra FNs bærekraftmål 2030. I stedet handler det om å operasjonalisere bærekraft i en reell do-good-mulighet, som Smith (2009) kaller det. For eventer der samarbeid med kommuner eller byer eller avgjørende, kan man se til Zürich og deres kunnskapsoverføring av miljøvennlig teknologi via ETZ Zürich og nye praksiser innenfor kollektivtransport. Dersom ikke samarbeidspartnerne er med på å generere sosial kapital på denne måten, vil det i stedet bli et spørsmål om skyld hvis ting går dårlig, som i tilfellet Bern tidligere nevnt. I en rapport fra de regionale myndighetene i Bern-kantonen (Bern, 2019) understrekes det for eksempel at Formel E-arrangementet var kontroversielt, og at befolkningens meninger var polariserte. Innholdet i debatten gikk blant annet på om elektromobilitet faktisk betyr en grønn sving for bilindustrien, ikke minst siden en av sponsorene var oljegiganten Saudi-Arabia. Til slutt handlet debatten om den generelle merverdien av større begivenheter, hvilket bringer oss til det tredje kriteriet for innovativ eventledelse.

Den tredje betingelsen for innovativ eventledelse er at eventet integreres i stedets eller byens langsiktige utviklingsmål. Svært ofte har store idrettsarrangementer pådratt seg store økonomiske ringvirkninger i ettertid som arrangørene enten ikke ville, eller kunne se for seg (Flyvbjerg, Budzier \& Lunn, 2020; Olderøien \& Solberg, 2019). Før løpet 
hadde Zürich oppnådd førsteplass på Arcadis Sustainable Cities Index 2016 og andreplass på Mercer Quality of Living Ranking 2018,5 og kunne derfor se Formel E-løpet som en naturlig forlengelse av dette arbeidet - gitt at arrangørene av det godtok byens betingelser for støtte. I motsatt tilfelle, som i Bern, var det nettopp mangelen på fingerspissfølelse for beboernes innspill og fraværet av langsiktig byutvikling som kunne veid opp for kritikken. Der planleggingsfasen ble oppfattet som god, var implementeringen ditto svak. Et eksempel som knytter sammen to kritiske punkter var svekking av kollektivtrafikken og ideen om å legge banetraseen så nær gamlebyen som mulig. Felles for disse punktene, understreker rapporten (Bern, 2019), var svikt i kommunikasjon med interessentene i implementeringsfasen. Dermed overtok kortsiktige problemer oppmerksomheten som ellers kunne blitt brukt til å skape interesse for langsiktige mål.

Endelig må vi gjøre oppmerksom på at dette er en enkeltcasestudie, noe som skaper generaliseringsbegrensninger for funnene våre. Like fullt mener vi at analysen viser hvordan Formel E-løpet avdekker «kontekst-spesifikke særtrekk» (Halkier 2011, s. 788), det vil si at den har læringsverdi for organisasjoner og eventer som opererer under lignende omstendigheter som et Formel E-løp (March et al., 1991; Sartore-Baldwin \& McCullough, 2016). For å styrke våre funn er det samtidig ønskelig med flere empiriske studier av samme fenomen for å utvikle disse tre betingelsene for innovativ eventledelse ytterligere.

\section{Referanser}

Agag, A. (2018, 4. juli). The pinnacle of street racing construction. Motorsport.com. Hentet 22. august 2018 fra https://www.motorsport.com/formula-e/news/agagzurich-eprix-street-racing-construction-1055817/3134858/

Batuev, M. \& Robinson, L. (2019). International governance of action sports: an organisational legitimacy perspective. I M. Winand \& C. Anagnoustopoulous (Red.), Research handbook on sport governance (s. 168-185). Cheltenham: Edward Elgar.

5 Zurich Revealed as Most Sustainable Global City, Arcadis, 12. september 2016. Lest 19. november 2018 på https://www.arcadis.com/en/global/news/latest-news/2016/o9/zurich-revealed-asmost-sustainable-global-city/. Se også https://www.zuerich.com/en/about-zt/sustainability 
Bern. (2019). Swiss E Prix Bern 2019. Auswertung des Anlasses durch die Stadt Bern. Hentet 22. juni 2020 fra https://www.bern.ch/mediencenter/medienmitteilungen/ aktuell_ptk/swiss-e-prix-in-bern-2019-gemeinderat-zieht-bilanz/dokumente/ bericht-auswertung-swiss-e-prix-bern-2019.pdf/download

Boddy, C. R. (2016). Sample size for qualitative research. Qualitative Market Research: An International Journal, 19(4), 426-432. https://doi.org/10.1108/QMR06-2016-0053

Brückmann, G., Huber, R. \& Bernauer, T. (2018). Das Zürcher Formel E Rennen im öffentlichen Meinungsbild (ISTP Paper Series 2, ETZ Zürich). Hentet fra https:// www.ethz.ch/content/dam/ethz/special-interest/dual/istp-dam/documents/ ISTP/Research/Mobility/ISTP\%2oPaper\%2oSeries/Das\%2oZ\%C3\%BCrcher\%20 Formel\%2oE\%2oRennen\%2oim\%20\%C3\%B6ffentlichen\%2oMeinungsbild\%2O \%2oFinal\%2oReport\%2005Jun18.pdf

Burgt, A. \& Kalinauckas, A. (2018, 12. juni). Why Formula E’s inaugural Zurich E-Prix surpassed expectations. Autosport.com. Hentet fra https://www.autosport. $\mathrm{com} / \mathrm{fe} /$ news/136703/why-fe-swiss-breakthrough-beat-expectations

Chen, Y. S. (2010). The drivers of green brand equity: Green brand image, green satisfaction, \& green trust. Journal of Business Ethics, 93(2), 307-319. https://doi. org/10.1007/s10551-009-0223-9

Cronin, B. (2019, 18. oktober). Swiss Formula E race facing financial difficulties. SportBusiness.com. Hentet 29. september 2020 fra https://www.sportbusiness. com/news/swiss-formula-e-race-facing-financial-difficulties/

Culiberg, B. \& Elgaaid-Gambier, L. (2016). Going green to fit in - understanding the impact of social norms on pro-environmental behaviour, a cross-cultural approach. International Journal of Consumer Research, 4o(2), 179-185. https://doi. org/10.1111/ijcs.12241

Dashper, K., Fletcher, T. \& Mccullough, N. (Red.). (2014). Sports events, society \& culture. London: Routledge.

Edwards, A. \& Skinner, J. (2009). Qualitative research in sport management. Oxford: Butterworth-Heinemann.

Elgaaid-Gambier, Monnot, E. \& Reniou, F. (2018). Using descriptive norm appeals effectively to promote green behaviour. Journal of Business Research, 82, 179-191. https://doi.org/10.1016/j.jbusres.2017.09.032

Flyvbjerg, B., Budzier, A. \& Lunn, D. (2020, 15. september). Regression to the tail: Why the Olympics blow up. Environment and Planning A: Economy and Space. https://doi.org/10.1177/0308518X20958724

Getz, D. (2009). Policy for sustainable and responsible festivals and events: Institutionalization of a new paradigm. Journal of Policy Research in Tourism, Leisure \& Events, 1(1), 61-78. https://doi.org/10.1080/19407960802703524 
Halkier, B. (2011). Methodological practicalities in analytical generalization. Qualitative Inquiry, 17(9), 787-797. https://doi.org/10.1177/1077800411423194

Hanstad, D. V. (2019). Organisasjon og ledelse i idretten. Bergen: Fagbokforlaget.

Herstein, R. \& Berger, R. (2013). Much more than sports: Sports events as stimuli for city re-branding. Journal of Business Strategy, 34(2), 38-44. https://doi.org/ $10.1108 / 02756661311310440$

Hilzinger, S. (2020, 6. februar). Trotz Konkurs nach E-Grand-Prix in Bern: Neue Frauenfelder Firma will Formel-E-Serie in der Schweiz halten. Tagblatt.ch Hentet 29. september 2020 fra https://www.tagblatt.ch/ostschweiz/frauenfeld/trotzkonkurs-nach-e-grand-prix-in-bern-neue-frauenfelder-firma-will-formel-eserie-in-der-schweiz-halten-ld.1192079

Howlett, M. \& Rayner, J. (2007). Design principles for policy mixes: Cohesion and coherence in 'new governance arrangements'. Policy and Society, 26(4), 1-18. https://doi.org/10.1016/S1449-4035(07)70118-2

Kolyperas, D., Maglaras, G. \& Sparks, L. (2018). Sport fans' roles in value co-creation. European Sport Management Quarterly, 19(2), 201-220. https://doi.org/10.1080/16184742.2018.1505925

Krause, D., Luzzini, D. \& Lawson, B. (2018). Building the case for a single key informant in supply chain management survey research. Journal of Supply Chain Management, 54(1), 42-50. https://doi.org/10.1111/jscm.12159

Kristiansen, E., Dille, T. \& Solem, B. A. A. (2019). Eventledelse - innledende betraktninger. I E. Kristiansen, T. Dille \& B. A. A Solem (Red.), Eventledelse. En forskningsbasert antologi (s. 9-19). Oslo: Universitetsforlaget.

Kumar, N., Stern, L. W. \& Anderson, J. C. (1993). Conducting interorganizational research using key informants. Academy of Management Journal, 36(6), 1633-1651. https://doi.org/10.5465/256824

Lawton, L. J. (2011). Introduction: Special issue on sustainability in the event management sector. Event Management, 15(4), 313-314. https://doi.org/ 10.3727/152599511X13175676722447

Lewis, J. \& Ritchie, J. (2003). Generalising from qualitative research. I J. Lewis \& J. Ritchie (Red.), Qualitative research practice (s. 263-286). London: Sage.

Maak, T. (2007). Responsible leadership, stakeholder engagement, and the emergence of social capital. Journal of Business Ethics, 74, 329-343. https://doi. org/10.1007/s10551-007-9510-5

Mackellar, J. \& Reis, A. C. (2014). World Rally Championships 2009 and 2011: Assessing the tourism value in Australia. Journal of Vacation Marketing, 20(1), 17-28. https://doi.org/10.1177/1356766713484728

March, J. G., Sproull, L. S. \& Tamuz, M. (1991). Learning from samples of one or fewer. Organization Science, 2(1), 1-13. https://doi.org/10.1287/orsc.2.1.1 
McKenna, S. A. \& Main, D. S. (2013). The role and influence of key informants in community-engaged research: A critical perspective. Action Research, 11(2), 113-124. https://doi.org/10.1177/1476750312473342

Mintzberg, H. (1979). An emerging strategy of 'direct' research. Administrative Science Quarterly, 24(4), 582-589. https://doi.org/10.2307/2392364

Mitchell, R. K., Agle, B. R. \& Wood, D. J. (1997). Toward a theory of stakeholder identification and salience: Defining the principle of who and what really counts. Academy of Management Review, 22(4), 853-866. https://doi.org/10.2307/259247

Neville, B. A., Bell, S. J. \& Whitwell, G. J. (2011). Stakeholder salience revisited: Refining, redefining, \& refuelling an underdeveloped conceptual tool. Journal of Business Ethics, 102(3), 357-378. https://doi.org/10.1007/s10551-011-0818-9

Næss, H. E. (2014). A sociology of the World Rally Championship. History, identity, memories and place. London: Palgrave Macmillan. https://doi.org/10.1057/ 9781137405449

Næss, H. E. (2020a). Corporate greenfluencing: A case study of sponsorship activation in Formula E motorsports. International Journal of Sports Sponsorship \& Marketing, 21(4), 617-631. https://doi.org/10.1108/IJSMS-09-2019-0106

Næss, H. E. (2020b). A history of organizational change. The case of Fédération Internationale de l'Automobile (FIA) 1946-2020. London: Palgrave Macmillan. https://doi.org/10.1007/978-3-030-48270-1

O'Kane, P. (2011). A history of the 'triple crown' of motor racing: The Indianapolis 500, the Le Mans 24 Hours and the Monaco Grand Prix. The International Journal of the History of Sport, 28(2), 281-299. https://doi.org/10.1080/09523367.2011.537920

Olderøien, L. \& Solberg, H. A. (2019). Økonomiske utfordringer med å avholde store arrangementer - moralske og etiske perspektiver. I E. Kristiansen, T. Dille, T. \& B. A. A Solem (Red.), Eventledelse. En forskningsbasert antologi (s. 79-95). Oslo: Universitetsforlaget.

Portes, A. (1998). Social capital: Its origins and applications in modern sociology. Annual Review of Sociology, 24(1), 1-24. https://doi.org/10.1146/annurev.soc.24.1.1

Rettie, R., Burchell, K. \& Riley, D. (2012). Normalising green behaviours: A new approach to sustainability marketing. Journal of Marketing Management, 28(3-4), 420-444. https://doi.org/10.1080/0267257X.2012.658840

Robeers, T. (2019). 'We go green in Beijing': Situating live television, urban motor sport and environmental sustainability by means of a framing analysis of TV broadcasts of Formula E. Sport in Society, 22(12), 2089-2103. https://doi.org/10. 1080/17430437.2018.1558212

Rowe, D. (1999). Sport, culture and the media: The unruly trinity. Buckingham: Open University Press.

Sartore-Baldwin, M. L. \& McCullough, B. P. (2016). Equity-based sustainability and ecocentric management: Creating more ecologically just sport organization 
practices. Sport Management Review, 21(4), 391-402. https://doi.org/10.1016/j.smr. 2017.08.009

Schüßler, E., Grabher, G. \& Müller-Seitz, G. (2015). Field-configuring events: Arenas for innovation and learning? Industry \& Innovation, 22(3), 165-172. https://doi.org/ $10.1080 / 13662716.2015 .1038098$

Shenton, A. K. (2004). Strategies for ensuring trustworthiness in qualitative research projects. Education for Information, 22(1), 63-75. https://doi.org/10.3233/EFI2004-22201

Smith, A. (2009). Theorising the relationship between major sport events and social sustainability. Journal of Sport \& Tourism, 14(2-3), 109-120, https://doi.org/ 10.1080/14775080902965033

Sotiriadou, P. \& Hill, B. (2015). Raising environmental responsibility and sustainability for sport events: A systematic review. International Journal of Event Management Research, 10(1), 1-11. Hentet fra http://hdl.handle.net/10072/99290

Stake, R. E. (2000). Case studies. I N. Denzin \& Y. S. Lincoln (Red.), Handbook of qualitative research (2. utg., s. 435-454). London: Sage.

Sturm, D. (2019). Formula E's green challenge to motorsport events, spaces and technologies. I H. Seraphin \& E. Nolan (Red.), Green events and green tourism: An international guide to good practice (s. 165-173). London. Routledge.

Swissinfo. (2020, 22. januar). Organiser of Swiss Formula E race goes bust. Swissinfo. ch. Hentet fra https://www.swissinfo.ch/eng/electric-cars_organiser-of-swissformula-e-race-goes-bust $/ 45509442$

Sylt, C. (2019, 24. november). Why Formula E's profits have been slow to rev up. Forbes. Hentet 24. november 2019 fra https:/www.forbes.com/sites/ csylt/2019/11/24/why-formula-es-profits-have-been-slow-to-rev-up/amp/

Tomlinson, A. \& Young, C. (2006). Culture, politics, and spectacle in the global sports event: An introduction. I A. Tomlinson \& C. Young (Red.), National identity and global sports events: Culture, politics, and spectacle in the Olympics and the football World Cup (s. 1-14). Albany, NY: State University of New York Press.

Tranter, P. J. \& Keefee, T. J. (2004). Motor racing in Australia's parliamentary zone: Successful event tourism or the Emperor's new clothes? Urban Policy \& Research, 22(2), 169-187. https://doi.org/10.1080/o811114042000229636

Trendafilova, S. \& McCullough, B. P. (2018). Environmental sustainability scholarship and the efforts of the sport sector: A rapid review of literature. Cogent Social Sciences, 4(1). https://doi.org/10.108o/23311886.2018.1467256

Twynam, G. D. \& Johnston, M. (2004). Changes in host community reactions to a special sporting event. Current Issues in Tourism, 7(3), 242-261. https://doi. org/10.1080/13683500408667981 
Tölkes, C. \& Butzmann, E. (2018). Motivating pro-sustainable behavior: The potential of green events - a case study from the Munich Streetlife Festival. Sustainability, 10(10). https://doi.org/10.339o/su10103731

Wilbaut, M. (2015). The estory: Undertaking the mobility challenge. FIA Formula E.

Hentet 9. september 2018 fra http://admin.fiaformulae.com/media/301817/estory_ undertaking-the-challenges-of-sustainable-mobility.pdf

Yin, R. (1994). Case study research: Design and methods (2. utg.). Beverly Hills, CA: Sage. 


\title{
«Vi vil børste vekk asken, men holde liv i ilden.» En kvalitativ studie av et mentorprogram for unge idrettsledere ${ }^{1}$
}

\author{
Birthe Kåfjord Lange \\ Hoyskolen Kristiania \\ Hans Erik Næss \\ Hoyskolen Kristiania
}

\begin{abstract}
Norwegian sports today are characterized on the one hand by a need to innovate organizationally and rethink current practices, and on the other hand to respect national traditions and values of sporting culture. This dual responsibility poses a particular challenge to sports leaders of tomorrow. Whereas other studies have examined sports management education or sports leadership qualities as solutions to this challenge, this chapter examines the potential of a mentoring program to improve leadership skills. It draws upon qualitative interviews with participants, mentors and organizers of the 2019/2020 Mentor Program for Young Sport Leaders offered by the Norwegian Federation of Sports (NIF) and the Norwegian Association of Student Sports (NSI). Our findings reveal that this program enables young sports leaders to become more aware of their personal strengths and weaknesses. At the same time, the transfer value they represent to the organization is conditioned by prior experience, attendance motives and mentee-mentor relations. Consequently, this program reproduces known pros and cons found in earlier research on mentoring programs, yet offers something new in the sense that it allows young leaders to be part of the solution to issues in Norwegian sports by defining the relevant problems.
\end{abstract}

Keywords: mentoring, sport, organizational ambidexterity, young leaders

\footnotetext{
$1 \quad$ Takk til Norges idrettsforbund (NIF) og Norges studentidrettsforbund (NSI) for tilrettelegging og inkludering av dette forskningsprosjektet i mentorprogrammet.
}

Sitering av denne artikkelen: Lange, B. K. \& Næss, H. E. (2020). «Vi vil børste vekk asken, men holde liv i ilden.» En kvalitativ studie av et mentorprogram for unge idrettsledere. I J. Bastesen, B. K. Lange, H. E. Næss \& A. N. Thon (Red.), Ledelse av mennesker i det nye arbeidslivet (Kap. 8, s. 207-230). Oslo: Cappelen Damm Akademisk. https://doi.org/10.23865/noasp.118.ch8 Lisens: CC-BY 4.o. 


\section{Introduksjon}

Å lede i idretten i dag handler om mer enn forvaltning av «den norske idrettsmodellen» - det vil si måten å organisere forholdet mellom stat, idrettsorganisasjoner, marked og frivillig sektor. Ledere skal fremdeles drive sine respektive forbund, kretser eller lag effektivt og til det beste for medlemmene i tradisjonell forstand, men de forventes også å ta ansvar for å sikre nytenkning og bedre tilpasning til idrettens endrede omstendigheter. Et eksempel er «Moderniseringsprosjekt» i regi av Norges idrettsforbund (NIF). Det peker på hvordan «den norske idrettsmodellen» utfordres om ikke norsk idrett tenker annerledes om organisering og ledelse, tydeliggjøring av ansvar og hovedoppgaver innenfor ulike organisasjonsledd, digitalisering av idrettsengasjement, og ikke minst frivillighetens rolle.

Dette kapitlet utforsker hvordan dette dobbeltansvaret for å både sikre effektiv drift og forvaltning av tradisjoner på den ene siden og å sikre nødvendig innovasjonsevne og nyskaping på den andre siden kan imøtekommes. Vårt fokus er på ledere og ledelse, ettersom økende profesjonalisering av norsk og internasjonal idrett innebærer store organisatoriske endringer både på klubb- og forbundsnivå. Samtidig er idretten som integrasjonsarena og verdiformidler i samfunnet i endring. I praksis betyr dette økte krav til rutiner, etterprøvbarhet og gjennomsiktighet fra både eksterne kontrollorganer og interessenter. Rundt idrettskonkurransene ser vi store endringer blant annet når det gjelder forholdet mellom kommersialisering og frivillighet, kontraktsforhold og tillit, samt hva som skal til for å oppnå relasjonsbygging i et kulturelt mangfoldig samfunn (Hanstad, 2019; Næss, 2019).

For å møte denne utviklingen, og være i forkant av den, satte Norges idrettsforbund (NIF) og Norges studentidrettsforbund (NSI) i gang et mentorprogram for unge idrettsledere med oppstart av første kull 2018/2019. Motivet for å opprette programmet er ifølge organisatorene å skape en arena hvor deltakerne opplever personlig utvikling og får faglig påfyll, samtidig som det legges til rette for nettverksbygging. ${ }^{2}$ Tjue delta-

2 Her bygger vi også på Mentorhefte - Faglig innhold, rammer og praktiske verktøy for Mentorprogrammet for unge ledere 2019/2020, som deles ut til deltagerne og ble gjort tilgjengelig for oss av programarrangørene. 
kere mellom 19 og 29 år, som enten har verv i studentidretten eller idretten for øvrig, får tildelt hver sin erfarne mentor som de forplikter seg til å gjennomføre 5-10 møter med i løpet av programmet. I tillegg samles alle deltakerne til tre helgesamlinger fordelt ut over en periode på 7 måneder. Et overordnet mål er å gi deltakerne mulighet til å utvikle seg som ledere i samspill med sin mentor.

Bakgrunnen for programmet er ifølge arrangørene en komprimert og mer kostnadseffektiv videreføring av et tidligere tilbud i regi av NIF og Norges idrettshøgskole, som ble avsluttet i 2017.3 Nyvinningen var å distansere seg fra det forrige tilbudets utdanningsbetingelser (det ga studiepoeng), og i stedet fokusere på samtidsutfordringer for unge ledere med verv i idretten. Dermed følger NIF/NSI ideen om å bruke mentorprogrammer som «inngrep» $\mathrm{i}$ individuelle karrierestiger som verktøy til videre organisasjonsutvikling (Comeaux, 2010). Programmet er utarbeidet i samarbeid med ekstern, profesjonell tilbyder av mentorprogrammer og lederutvikling, og er delt i tre temaer: 1) meg som leder og oppstart mentoring; 2) å lede gjennom andre; 3) ledelse av organisasjoner og avslutning mentoring. Basert på kvalitative intervjuer med både programutviklere, mentorer og mentee-er om disse temaene, baserer vi kapitlet på tre forskningsspørsmål:

1) I hvilken grad opplever deltagerne å vore bedre rustet til situasjoner og omstendigheter der de må lede «med begge hendene»? Spørsmålet er basert på at behovet for å ivareta tradisjoner med den ene hånda og tenke nytt med den andre kan trekke folk i ulike retninger (den norske versjonen av «organizational ambidexterity», se Duncan, 1976; O’Reilly \& Tushman, 2008, 2011). Løsningen finnes ofte i hvordan ledere selv oppfatter sitt eget strategiske handlingsrom, som handler om hvilke alternativer de vurderer som aktuelle før de tar sine beslutninger i eget lederskap.

2) Er mentorprogrammer $i$ denne formen en hensiktsmessig arena for personlig lederutvikling innen idrett? Spørsmålet oppstår fordi

3 Informasjon om det forrige programmet kan leses her: http://www.ndf.no/getfile.php/1614/Utdanning\%2ofor\%2oyngre\%2oledere\%2oi\%2oidretten.pdf 
mentorprogrammer generelt er kritisert for å være for instrumentelle. Det vil si at de brukes som en metode, generalisert til en bransje, en lederrolle eller sektor, for å bevisstgjøre mentee-ene om hvordan en utfordrende situasjon kan møtes og hvordan de selv kan imøtekomme fremtidige utfordringer som ledere.

3) Bidrar mentorprogrammet til å utvikle den type ledere idretten «trenger»? Oversiktsartikler om lederutvikling og idrett gjennom fire tiår med fagutvikling understreker at det fortsatt er et gap mellom generelle ledelsesutdannelser og idrettens eget behov for spesifikk lederkompetanse (Chelladurai, 1990; Ferkins, Skinner \& Swanson, 2018a; 2018b; Megheirkouni, 2017; Peachey, Damon, Zhou \& Burton, 2015). En internasjonal undersøkelse av idrettsledelsesutdanninger fra ni europeiske land presiserer disse kravene (NASME, 2019), som vi skal komme tilbake til senere.

Resten av kapitlet er organisert på følgende måte. Først vil vi gjennomgå tidligere forskning på mentorprogrammer generelt, og bruken av disse i idretten. Dernest vil vi presentere datamaterialet og metodiske vurderinger. En tredelt analysedel følger opp forskningsspørsmålene over, før vi avslutter med å reflektere over hvordan dette programmet bidrar til å forme morgendagens idrettsledere.

\section{Tidligere forskning på mentorprogrammer: En kritisk gjennomgang}

I innledningen til The SAGE Handbook of Mentoring oppsummerer Clutterbuck mfl. mentorfenomenets virkefelt i fem aspekter: en faglig filosofi; betydningen av kontekst; relevansen av implementering; verdien av dynamikk og kommunikasjon; formaliseringen av det i programmer (Clutterbuck, Kochan, Lunsford, Dominguez \& Haddock-Millar, 2017). Disse fem aspektene er gjengangere i mentorfenomenets utvikling, men det siste punktet fikk sitt faghistoriske gjennombrudd på 1970-tallet. Ifølge Hegstad og Wentling (2004) var det R. M. Kanters forskning på mentorordninger i større organisasjoner (Kanter, 1977) som satte en tidlig standard, før Kram $(1983,1985)$ systematiserte mentorprogrammenes funksjon og 
innflytelse på to prosesser: enkeltpersoners psykososiale utvikling og karriereutvikling. Krams forskning fikk innflytelse på grunn av hennes fokus på den gjensidige nytteverdien av begge mentorprosessene. Siden mentorprosesser antas å gi innsikt i organisasjonens maktstrukturer og kulturspesifikke innhold, vil det være nyttig å utnytte dette til egen og organisasjonens vinning (Kram, 1985; Hegstad \& Wentling, 2004). Etter hvert som mentorprogrammer vokste til å bli et populært format for lederutvikling, ble også innholdet mer mangfoldig og tilpasset kulturelle betingelser (Merrick, 2017), samtidig som de også ble mer standardisert. Ifølge Ekeland (2014) har vellykkete mentorprogram følgende kjennetegn:

- tydelig og klar målsetting

- forankring og støtte fra toppledelsen

- én ansvarlig for gjennomføring av programmet

- utvelgelse av mentorer og mentee-er

- koblingsprosess

- tydelig struktur

- etiske retningslinjer

- evaluering av programmet

Samtidig er det mange kritiske røster til denne generelle forståelsen og bruken av mentorprogrammer, og kritikerne kan deles i seks grupper. En gruppe kritikere peker på at «one size fits all»-tankegangen ikke tar hensyn til fag-, sektor-, eller rollespesifikke krav til lederkompetanse (Allen, Finkelstein \& Poteet, 2009). En mengde studier henviser til Kathy Krams forskning $(1983,1985)$ som utgangspunkt, av dem mange ukritisk og uten å ta i betraktning arbeidenes kvalitative innfallsvinkel. Basert på intervjuer med unge ledere mellom 26-34 år viser Kram til fire utviklingsfaser av en mentorrelasjon: initiering, kultivering, separasjon og redefinering. Forutsetningen som ofte overses, er at Kram ser for seg dette over lang tid, nærmere ti år. Dette er dermed lite relevant for mentorprogrammer der tidsperspektivet er mye kortere. Beslektet med dette er at relevansen av programmet avhenger av i hvilken grad det passer med konteksten det befinner seg i. En av nestorene i mentorforskning og en sentral inspirasjonskilde til NIF/NSIs mentorprogram, David Clutterbuck, hevdet 
for nesten tjue år siden at dersom man ikke tar konteksten i tilstrekkelig betraktning, vil det svekke troverdigheten til forskningen på mentorfenomenet (Clutterbuck, 2003).

En annen gruppe kritiske røster peker på det sårbare leddet i hvorvidt mentorens kompetanse og personlighet står til mentee-ens ønsker. Dette har sammenheng med hvordan «mentor» defineres. Selv om det finnes veldig mange definisjoner, vil Sands, Parson, og Duane (1991) kunne inkludere mye av det som diskuteres i dette kapitlet: «a professional guide who nurtures and promotes the learning and success of his or her protege(e)» (s. 124). Innen idrettsforskningen har Weaver og Chelladurai (1999) en tilsvarende tilnærming, der mange av de klassiske elementene er lånt fra mentorprogrammenes faghistorikk - deriblant Kram (1983). Allen, Finkelstein og Poteet (2009) hevder på sin side at det ikke finnes noen «best practice»-eksempler på kobling av mentor og mentee, fordi omstendighetene og folk er så forskjellige. Et annet aspekt er at dette forholdet kan gå seg til, selv om utgangspunktet er en kollisjon på det personlige plan. Samtidig viser Allen, Finkelstein og Poteet (2009) til at jo bedre forankret mentorprogrammet er i den aktuelle bransjen eller til og med bedriften, jo større er sannsynligheten for å skape en god kobling til å begynne med. Dette punktet skal vi komme tilbake til som særdeles relevant for vår case.

En tredje kritikk går på hvorvidt mentorprogrammet stimulerer til nytenkning eller reproduserer status quo. $\AA$ «lede med begge hendene», en metafor om å ivareta flere hensyn samtidig (såkalt «organizational ambidexterity»; se Duncan, 1976; O’Reilly \& Tushman, 2008, 2011), er en stadig mer aktuell problemstilling for virksomheter på tvers av bransjer gitt stadig høyere generell utviklingstakt, tøff globalisert konkurranse og teknologiutvikling. Begrepet bygger på argumentet fra Levinthal og March (1993) om at «the basic problem confronting an organization is to engage in sufficient exploitation to ensure its current viability and, at the same time, devote enough energy to exploration to ensure future viability» (Levinthal \& March, 1993, s. 105). Der eksempelvis Birkinshaw, Zimmermann og Raisch (2016) viser at variasjoner av tohendighet er mulig for næringslivet i en konkurransesituasjon, blir det i en idrettskontekst avgjørende hvordan relasjonen som Levinthal og March (1993) påpeker 
skal balanseres opp mot dens særskilte interessenthensyn (Hanstad, 2019; Næss, 2019). I lys av disse hensynene hevder Chelladurai og Kerwin (2018, s. 212) at en av fordelene med slike programmer er å kunne kultivere ledertalenter fra innsiden, og på den måten unngå oppstartskostnadene ved å rekruttere folk utenfra. På den ene siden er dette et rasjonelt mål som kan tjene idretten, da dens organisasjoner ønsker å opprettholde deres autonomi fra andre sektorer i samfunnet. På den andre siden kan internrekruttering skape utilsiktede føringer som via reproduksjon av kunnskap reduserer tilfanget av nye, potensielt strategisk relevante perspektiver når omstendighetene endres (Leeder \& Cushion, 2019).

En fjerde kritikk går på at det lederfaglige fokuset har en utilsiktet slagside. Kochan, Kent og Green (2015) hevder at den kulturelle innflytelsen fra både omstendigheter, mentorers bakgrunn og mentorprogrammers iscenesettelse påvirker resultatet. Mentorprogrammer er med andre ord sosiale konstruksjoner av kunnskap som mentorene søker å overføre til mentee-ene sine (Leeder \& Cushion, 2019). Her er det relevant å trekke inn et kjønnsperpektiv, da samfunnets hegemoniske normer og kultur kan hindre erkjennelse av likestillingsbegrensningene et slikt program kan innebære (Bower, 2009; Chester \& Mondello, 2012; Hale 1995; Stalker, 1994). Pfister og Radtke (2009) peker spesielt på hvordan disse normene kommer til uttrykk i hva som er en idealleder, som ifølge dem er karakterisert ved høy sosioøkonomisk status, frihet fra familieplikter og spisse albuer - egenskaper som ifølge dem er mer typisk for menn enn kvinner. Samtidig viser flere studier av kvinnelige mentee-er ingen signifikante forskjeller mellom mannlige og kvinnelige mentorer når det gjelder mentee-enes opplevde nytte av mentorprogrammet, selv om rollemodellkoblingen kunne være bedre dersom mentoren var en kvinne (Burke, Burgess \& Fallon, 2006; Høigaard \& Mathisen, 2009).

En femte type kritikk påpeker at troen på mentorprogrammets «intervenerende styrke» kan gi et falskt bilde av effektivitet (Comeaux, 2010). Dette er det svært aktuelt å være observant på med tanke på NIF/NSI sitt mentorprogram, der kandidatene etter gjennomført program skal

- ha god kjennskap til idrettens organisering

- ha opplevd økt mestring og trivsel i sitt nåværende verv 
- ha økt kompetanse om ledelse og refleksjon rundt seg selv i lederrollen

- fått kjennskap til relevante verktøy til bruk i egenutvikling og inn i egen organisasjon

- lært å ta ansvar for og blitt selvstendig i sin egenutvikling i lederrollen

- fått større nettverk på tvers av idretter og utviklet sin relasjonskompetanse

- ha definert videre ambisjoner for verv på ledernivå i idretten

I sin metastudie der utviklingen av grupper med og uten mentorer sammenlignes, er forskningen tvetydig. Der Underhills metastudie (2006) fant at mentorordninger signifikant forbedrer individuelle karrieremuligheter, i særdeleshet uformelle mentorforhold, viser en annen metastudie at selv om mentorordningen er assosiert med en rekke positive trekk (helse, karriere, motivasjon), er effekten relativt liten (Eby, Allen, Evans, Ng \& Dubois, 2008). Noe av dette handler om at ulike metoder kan avdekke ulike grader av effektivitet, og hvordan begrepet «mentoring» er definert. Foruten et økt fokus på å planlegge evalueringsprinsippene som del av mentorprogrammets design, peker Colley på at en kvantitativ tilnærming bidrar til «a limited view of what tends to happen as opposed to the rich possibilities of what can happen» (Colley, 2003, s. 3).

En siste type kritikk anerkjenner at mentorprogrammer skaper lederbevissthet, men stiller samtidig spørsmål om det har betydning for deltagernes egne arbeidsplasser. Hegstad og Wentling (2004, s. 423) påpeker at en stor del av organisasjonene som dominerer mentorlitteraturen også befinner seg på Fortune 500-listen. På den ene siden er det fordeler med friskt blod i idrettsorganisasjoner, slik flere av informantene våre pekte på. En mentor sa for eksempel at «Det er viktig å ta vare på det som er unikt. Samtidig må vi kikke litt rundt oss for å komme litt videre. Vi skal ikke gå helt inn i næringslivstankegangen, men jeg tror samspillet vil være positivt for alle». På den andre siden kan blandingen av bransjer forsterke utfordringene som mentorprogrammet er laget for å løse. Som en forlengelse av kjønnsdebatten over, hevder Hovden (2010) at hvis vekten på idrettsorganisatorisk fornyelse bygger på tradisjonell, lederfaglig 
kompetanse risikerer man å fremmedgjøre kvinnelige ledere. Årsaken er at «enkelte former for maskulinitet og stereotype ideer om kjønn er inngrodd i de dominerende lederdiskursene i idrettsorganisasjoner» (Hovden, 2010, s. 189).

I lys av disse seks kritikkene vil vi avrunde med å si at med fokus hovedsakelig på trener-utøver-relasjoner og kjønnsdimensjoner når det gjelder mentorprogrammer i idretten, er det betydelig rom for utforskning av perspektiver som går mer på ledelsesfaglig utvikling innen idretten, strategisk handlingsrom og selvutvikling (Jones, Harris \& Miles, 2009; Weaver \& Chelladurai, 1999). For å svare på spørsmålet om hvorvidt deltagerne i NIF/NSIs mentorprogram har reflektert over disse perspektivene, vil vi nå gå over på det metodologiske grunnlaget for analysen.

\section{Data og metode}

Datagrunnlaget for dette kapitlet er 22 kvalitative intervjuer. Av ulike grunner deltok ikke alle mulige intervjuobjekter i studien, men det gjenværende utvalget er like fullt strategisk i den forstand at de har hensiktsmessige erfaringer i lys av forskningsspørsmålene våre. Av totalt 20 mentor/mentee-par, bestod utvalget av 14 programdeltagere (10 menn og 4 kvinner), 6 mentorer ( 3 kvinner og 3 menn) og 2 programorganisatorer. Valget av kvalitative intervjuer er basert på vårt ønske om å få innsikt i deltagernes erfaringer, snarere enn å foreta effektmålinger av programmet etter gitte indikatorer. Disse erfaringene var videre relevante å få tak i på grunn av vår forforståelse av behovet for lederfaglig fornyelse i norsk idrett. Av den grunn, i tillegg til at covid-19-pandemien umuliggjorde fysiske intervjuer, ble «fokusert intervju» med bruk av digitale verktøy som Zoom og Microsoft Teams en nyttig innfallsvinkel til hvordan organisere datainnsamlingen.

Opprinnelig et begrep lansert av sosiologene Robert K. Merton og Patricia Kendall på 1940-tallet, ble «fokusert intervju» i flere tiår utviklet som en variant av en-til-en-dybdeintervjuet ellers kjent i kvalitativ forskning (Merton, Fiske \& Kendall, 1990; Merton \& Kendall, 1946). Hensikten bak varianten, som både er praktisk (intervjuene varte mellom 30-45 minutter) og faglig, er å vurdere responsen fra intervjuobjektene til forskernes 
situasjonsforståelse som danner grunnlaget for samtaleguiden. Denne situasjonsforståelsen er oppsummert i innledningen til dette kapitlet. I kontrast til Merton, Fiske og Kendall (1990), antar vi imidlertid ikke at forforståelsen gjør oss i stand til å skille mellom sakens «objektive fakta» og «the subjective definitions of the situation» (Merton, Fiske \& Kendall, 1990, s. 4). Nettopp fordi fokuserte intervjuers styrker er å gå rett til kjernen, eller å søke «subjective experiences of persons exposed to the pre-analysed situation in an effort to ascertain their definitions of the situation» (kursiv original) (Merton, Fiske \& Kendall, 1990, s. 3), var vi ikke ute etter å teste forklaringer på hvordan noe hang sammen (se også om denne typen intervjuer i Tjora, 2017).

Målet var simpelthen å få et rikere bilde av hva mentorprogrammet hadde tilført av ledelsesfaglige elementer i idrett til deltagerne, og hva slags rolle mentorene, de fagansvarlige og organisatorene spilte underveis. Derfor var intervjuene mer samtalepreget om temaene introdusert i innledningen, enn organisert etter strenge spørsmålsrekker. Funnene fra intervjuene ble deretter kategorisert etter temaer som var knyttet til forskningsspørsmålene. Disse elementene mellom temavariasjoner tilknyttet forskningsspørsmålene ble deretter gruppert i svarmønstre. Det betyr altså om det var noe felles, eller om noe sto i kontrast blant intervjuobjektenes oppfatning av Mentorprogrammets innhold og innflytelse på egen og organisasjonens utvikling. I neste avsnitt presenterer vi resultatet av denne analysen, og diskuterer funn underveis opp mot teori og tidligere forskning for å koble dem til konteksten vi innledet dette kapitlet med.

\section{Analyse}

Generelt er inntrykket at mentorprogrammet i stor grad har vært en berikelse for deltagerne. Med få unntak er det enighet om at mål, verktøy og prosesser, for ikke å glemme mentorrelasjonene, har hjulpet dem til å bli bedre rustet til fremtidige lederutfordringer. Konteksten - idrett er ivaretatt både gjennom praktiske sesjoner og et underliggende motiv, ifølge arrangørene, om å følge en europeisk forståelse av «mentoring» (som fokuserer på tillit og gjensidig kunnskapsutveksling), snarere enn 
en amerikansk (fokusert på prestasjoner og karriereavansement) (se for eksempel Merrick, 2017). Samtidig er det et tydelig funn, dog litt overraskende med tanke på programmets målsetting, at det i liten grad er spesialdesignet for å gjøre idrettsorganisasjonene mer moderne i form av tilførsel av ledertalenter. Dette kan imidlertid være både en styrke og en svakhet, som vi skal komme tilbake til, men først vil vi gå igjennom funn knyttet til hvert enkelt forskningsspørsmål.

I hvilken grad opplever deltagerne å vore bedre rustet til situasjoner og omstendigheter der det å lede «med begge hendene» er nødvendig?

Respondentene var i overraskende liten grad inne på utfordringer knyttet til behovet for tohendig ledelse. Et par respondenter mente at gjennom å satse på å utvikle unge ledere som dem selv, ville idretten automatisk få øt fokus på nyskaping og innovasjon, siden yngre ledere var mer opptatt av nyskaping enn eldre, etablerte ledere. En av mentorene ga uttrykk for at $h^{\star} n$, gjennom den tette relasjonen til sin mentee, fikk bedre forståelse og nye perspektiver på saker $h^{\star} n$ tidligere gjerne hadde hatt en mer tradisjonell oppfatning av. Slik sett kan det hevdes av mentorprogrammet bidrar til styrket tohendighet blant idrettslederne som deltar i programmet som mentorer, heller enn blant mentee-ene. Enda andre mente at selv om det ble arrangert programmer som dette, har idretten en utfordring knyttet til å slippe unge ledere til i lederposisjoner, samt å ta på alvor de innspill eller forslag som unge ledere faktisk kommer med. Samtidig ga en informant tydelig uttrykk for at $\mathrm{h}^{\star} \mathrm{n}$ hadde vanskelig for å se at det kunne bli noen revolusjonerende endringer i idretten uansett fremover (eksemplifisert ved at grasrota ikke var interessert i digitalisering, men heller å få best mulige praktiske rammer å drive sin idrett innenfor).

Derimot var informantene påpasselige med å betone at programmet ga dem større lederforståelse på personlig plan. For eksempel var det en som trakk frem verdibasert ledelse som relevant når det gjaldt å balansere kvalitet med effektivitet. Det som gjorde informanten oppmerksom på dette på samlingen, var en gruppeøvelse der de fikk utdelt fire lapper med jobbtitler knyttet til ulike navn. Spørsmålet om hvem disse personene var, ble deretter gjenstand for debatt mellom gruppemedlemmene. 
Denne gruppen - som besto av svært forskjellige personer - kom raskt til enighet på grunn av tydelige roller og kompetanse, og viste ifølge informanten i praksis både betydningen av et mangfold i organisasjonen og en verdibasert ledelse av oppgaveløsning.

Deler av dette inntrykket blant informantene kan, ifølge både mentee-er og mentorer, forklares med stor variasjon i hvor målbevisste deltagerne var, og i hvilken grad de ble påvirket av sine organisasjoner til å søke om opptak. Noen var veldig tydelige på at deltagelsen var organisasjonsdrevet, og fremhevet hvordan moderorganisasjonen og nettverk hadde oppfordret dem til å søke opptak til programmet, mens andre hadde mer individuelle motiver. Eller, som en av mentorene sa: «Noen særforbund skal ha med noen for å bare for å liksom check, da har vi gjort utviklingsjobben.» En annen mentor fulgte opp med å si at «Jeg tror nok det var en del som var der fordi det er greit å ha på CV - som er en legitim anledning, for å si det sånn, men jeg tror nok kanskje man må se lite grann på utvelgelseskriteriene som legges til grunn her».

En annen forklaring kan være at siden idretten fikk mindre plass i programmet som ledelsesarena enn det man kanskje kunne anta, ble det ikke rom for diskusjoner som kunne gavnet norsk idretts behov for tohendig ledelse:

Det er ikke noe tvil om at NIF som organisasjon har en vei å gå når det gjelder å lære sine idrettsledere hva det vil si å være en del av norsk idrett. Det er jo ikke sånn at NIFs lov ${ }^{4}$ gjelder og så driter vi i alt annet, men vi oppfører oss jo sånn, og vi kommuniserer sånn.

Slike perspektiver var det imidlertid langt imellom blant informantene, selv om en og annen indirekte snakket - uoppfordret - om behovet for bedre styring av norsk idrett. En del av forklaringen kan være at organisatorisk innovasjon ikke var høyt prioritert av arrangørene. En av dem sa det treffende: «Vi vil børste vekk asken, men holde liv i ilden», når vi snakket om hvor behovet for fornyelse i norsk idrett lå. Samtidig var det ikke slik at nytenkning kun var en bonus. For denne personens

4 «NIFs lov» er kallenavnet på vedtektene som gjelder for medlemmene av Norges Idrettsforbund (NIF). 
vedkommende var det tydelig at det var mange utfordringer for norsk idrett, hvorav den kanskje viktigste var å snu på det: i stedet for å fore deltagerne med kunnskap om hvordan lede med begge hendene, kunne det å inkludere dem i utviklingen av seg selv og sin organisasjon skape ringvirkninger som snudde forholdet mellom tradisjon og nytenkning til en mulighet i stedet for noe problematisk. Men hvis dette skulle bli et tydeligere premiss for programaktivitetene, kunne det hende at deltagerne ville henge seg opp i å nå mål knyttet til det i stedet for å oppdage at de hadde lært noe de egentlig ikke hadde satt som mål - men som samtidig var essensielt for å nå målene sine. Denne balansen, mellom på den ene siden å fortelle deltagerne alt de burde lære og bruke mentorene til å operasjonalisere dette, og på den andre siden overlate til deltagerne å finne ut av ettersom det er der mye av læringsverdien i mentoring ligger, er en krevende øvelse ettersom bredden av deltagere, organisasjoner og mentorer tidvis ble oppfattet som et hinder til effektivitet.

Er mentorprogrammer i denne formen en hensiktsmessig arena for personlig lederutvikling innen idrett?

Et tydelig funn på tvers av intervjuene var at mange av mentee-ene opplevde personlig utvikling som det største utbyttet av programmet. De rapporterer eksempelvis å ha blitt tryggere i lederrollen, blitt mer bevisst på å forstå andres perspektiver og verdier, og å ha blitt mer bevisst på å sette seg personlige utviklingsmål som leder - ikke bare konkrete prestasjonsmål innen idretten, slik de tidligere hadde gjort. For eksempel sa en av informantene at $\mathrm{h}^{\star} \mathrm{n}$ hadde blitt «mer bevisst på hvilken ledertype jeg er, mine styrker og svakheter. Jeg er litt sånn struktur-og-kompis-leder, ved å være personlig uten å være privat i det å skape tillit. Man må være fleksibel i forhold til å lytte til de menneskene rundt deg, hva de sier. Jeg tenker slik: Min jobb er å spille deg god!». Med tanke på hva informanter, mentorer og programarrangører selv har brukt programmet til i etterkant, mener vi det er rimelig å anta at denne formen for opplevde positive utviklingseffekter er et reelt bilde på faktisk personlig utvikling.

Enigheten kan imidlertid også relateres til en av kritikkene rettet mot mentorprogrammer; nemlig at det kan oppstå et falskt bilde av 
effektivitet. Det å få oppmerksomhet i seg selv har siden Hawthorne-studiene på 1930-tallet ofte blitt forvekslet med reell innsikt i hva denne oppmerksomheten skal føre til, noe som også gjelder mentorprogrammer (Eldridge \& Dembkowski, 2016). Samtidig virket det som om de fleste informantene var svært fornøyd med hva slags kompetanse og personlige egenskaper de ble utfordret på av mentorene, selv om enkelte ytret ønske om langt flere møter ansikt til ansikt for å utvikle seg på områder de mente var viktige. Et av disse områdene for denne informanten var sponsorrelasjoner, og $h^{\star} n$ påpekte at det var der verdien for $h^{\star} n$ lå - i det å følge mentoren på jobb i konkrete situasjoner som krevde lederegenskaper for å få ting gjort. Der relasjonen ikke stemte faglig sett, som var i et fåtall av tilfellene, var det tilsvarende skuffelse over å ikke kunne utnytte dette mentor-mentee-forholdet til gjensidig vinning. Det skal sies at den mest kritiske informanten heller ikke hadde noen ambisjoner om en karriere i idretten, samtidig som $h^{\star} n$ var meget godt belest på ledelsesfag fra før.

Selv om mentee-ene rapporterer om opplevd personlig utvikling gjennom programmet, er det mer usikkert og utydelig hvilke effekter dette har for forbund/kretser. En av mentorene nevnte for eksempel at «Verdien lå i lederverktøyene, ikke i idrettsfaglige perspektiver. Mye av det vi jobber med kan du bruke hvor som helst». Flere mentee-er gir (implisitt) uttrykk for en antakelse om at når unge ledere tør ta mer plass i sine respektive styrer, fyller lederrollen i større grad med det de brenner for og uttrykker egne meninger på flere arenaer, vil det gi bredere tilfang av perspektiver i utvikling av fremtidens Idretts-Norge. Enkelte respondenter var imidlertid inne på en sentral betingelse: for at den personlige utviklingen også skal komme idretten til gode, må deltakerne forbli i idretten, noe som er usikkert. Dette gjelder særlig for NSI-lederne, som har sine lederverv mens de studerer. En av arrangørene ga uttrykk for at de også håpet mentorprogrammet ville motivere NSI-lederne til å komme tilbake og ta andre lederverv i idretten, etter at studietiden deres var over. Et sentralt spørsmål blir imidlertid hvem eventuell verdiskapning i mentorprogrammet tilfaller, og i hvilken grad idretten faktisk beholder (deler av) den. En av mentorene mente det ikke var noe enten-eller her: 
Jeg tror kanskje vi kunne fokusert på at det var du som fikk denne utviklingen, og så bruker du forbundet ditt for å nå dit, eller øve på ting og skape endringer. Kanskje også mer motiverende for de som er med, at de er der for å skape endring for seg selv. Jeg hadde inntrykk at av noen var veldig opptatt av hva forbundet mente. At de var sendt på dette for å gjøre en endring av ditt forbund. Men det er ikke sikkert at det er det som er den beste veien til målet.

Andre mente at svaret på dette spørsmålet var avhengig av hva slags motivasjon deltagerne gikk inn i programmet med, der enkelte nok hadde mer press på seg fra organisasjonen enn andre. En av deltagerne sa for eksempel: «Dette gjaldt ikke for meg, men jeg tror de andre forbundene var mer sånn konkrete, 'dette skal du levere på etterpå'». I ytterste instans vil dette påvirke lederes (strategiske) handlingsrom, ettersom ulike forventninger til hva deltakerne skal «levere» vil gi ulikt utbytte av et mentorprogram. Dersom unge ledere påvirkes i retning av «gårsdagens» løsninger formidlet av sine mentorer, mens omstendighetene i dag indikerer et behov for andre løsninger, vil det potensielt begrense handlingsrommet til de yngre lederne og gjøre det mindre strategisk relevant.

\section{Bidrar mentorprogrammet til å utvikle den type ledere idretten trenger?}

Deltagerne er overveiende positive til å svare ja her, det samme var mentorene. En mentor beskrev eksempelvis morgendagens «idealleder» som en «tillitsbygger, åpen og fremoverlent, og som ønsker nye ting velkommen. Spesielt etter dette digitaliseringhoppet som vi har hatt er det viktig å være for endring. Og det tror jeg de yngre absolutt er med på.» Som et eksempel sa en deltager at

Frivillig-aspektet er helt sentralt i idretten, og du kan ikke lede som en OECD-topp.

Som land er vi annerledes, og jeg tror du kommer lenger i Idretts-Norge ved å være ydmyk og forståelsesfull og snakker på lik linje med folk. Dette er blitt tydeligere for meg nå, og passer den norske idrettsmodellen veldig bra.

Andre var mindre opptatt av Idretts-Norge som kontekst: «Det er mye lettere å lese seg opp på samfunnsutfordringer og idrettens organisering enn å lære seg å bli en god leder. Du melder deg på mentorprogrammet for den personlige utviklingen - veldig mange av oss, i alle fall.» I forbindelse 
med dette temaet oppdaget vi et behov blant informantene om å nyansere hva programmet bidrar til for idretten, ikke minst fordi flere av dem ikke så for seg en karriere i idrettsledelse. Ifølge en mentor handlet det primært om å bevisstgjøre mentee-ene på «de menneskelige egenskapene», noe som samtidig «er vanskelig å utdanne gjennom et mentorprogram». Der idretten var en fremtidig karrierevei, var det samtidig avgjørende, ifølge en annen av mentorene, at de ble klar over hva slags del av samfunnet de befant seg i. $\mathrm{H}^{\star} n$ sa for eksempel at «Når studenter kommer ut i hverdagen, er det nok en litt annen virkelighet enn det de har lært gjennom studiet sitt», og la til at det generelt er altfor liten bevissthet om kompleksiteten i forholdet mellom verdigrunnlaget til norsk idrett og måten norsk idrett er organisert på.

Fokuset på det at man skjønner grunnmuren i det vi driver med, blir viktigere og viktigere fordi vi er store. Selv toppidrettsutøvere har ingen forutsetninger for å vite hvordan resten av organisasjonen virker når de sitter på andre siden av bordet. Er min påstand. Og så har jeg dessverre rett. Ofte.

Samtidig var det deltakere som kommenterte at de ikke opplevde mentorprogrammet som fremtidsrettet nok. De etterlyste eksempelvis større mangfold, og mente at både programmets mentee-er og mentorer er en relativt homogen gruppe, og at dette begrenser den personlige utviklingen deltakerne kunne fått. Arrangørene fortalte imidlertid om et målrettet arbeid for å øke mangfoldet i programmet, og at mangfoldet var styrket fra første til andre gjennomføring. Det er et uttalt mål at programmet skal gjenspeile det mangfoldet deltakerne møter i sine verv i Idretts-Norge, fordi det er oppfattet å være viktig for å sikre økt forståelse for helheten. Andre kommenterte også at programmet i liten eller ingen grad tar opp store utfordringer knyttet til behov for digitalisering og kommunikasjonsutfordringer. For eksempel gjaldt det å rekruttere medlemmer og sponsorer, og det å jobbe politisk for å få gjennomslag hos bevilgende myndigheter. Det savnes også at programmet tar opp utfordringer knyttet til å sikre tettere kobling mellom styrer (i krets eller forbund) og grasrota: hvordan kan man som leder/styremedlem sikre større engasjement i bredden av egne medlemmer? Erfaringer fra rask og nødvendig digitalisering under koronakrisen ble nevnt som et interessant 
eksempel. I klubber og forbund hvor det typisk kun er styret som stiller på årsmøtet, dukket det opp langt flere medlemmer på de digitale årsmøtene man var tvunget til å gjennomføre i vår. Dette ble omtalt som et tankekors for fremtidens idrettsledere, og viktig lærdom når det gjelder behovet for fornyelse av idrettens mer tradisjonelle løsninger.

Et beslektet aspekt her er organisasjonsveksten i norsk idrett samtidig med at den norske modellen består, der frivillige spiller en uvurderlig rolle. For en av mentorene var det en kjepphest å få de frivillige til å forstå hva de deltok på når de engasjerte seg i idretten, og idrettsorganisasjonene til å forstå hvordan de skulle behandle frivillige:

Hvis vi mener at den modellen [den norske] er feil, fordi den krever så mange frivillige, så må vi gjøre noe med det. Men all den tid vi ikke prioriterer å gjøre det fordi folk synes det er litt tungt å snakke om, så går vi rundt i denne lille andedammen og ingen tør egentlig å si noe. Og så kaster vi bort masse penger og ressurser og så skjer det nada!

Et annet aspekt, som nevnt innledningsvis, er de politiske omstendighetene som norsk idrett må forholde seg til. En mentor mente det var lite fokus på det i programmet, men samtidig brukte mentoren litt tid på det siden $\mathrm{h}^{\star} \mathrm{n}$ kjenner det politiske betingelsene for norsk idrett godt, og mente det var «utrolig relevant med den kunnskapen for å være med det i offentlige ordskiftet». Mange av informantene påpekte dessuten at det å få ledelsesfaglig påfyll fra noen utenfor idretten som verdifullt, da et rent fokus på Idretts-Norge kunne begrense mulighetene for «å lede med begge hendene».

\section{Konklusjon}

Konklusjonen er at det ledelsesfaglige ved NIF/NSIs mentorprogram for unge ledere er mer knyttet til individuell utvikling snarere enn å være et verktøy for å forbedre Idretts-Norge. Samtidig representerer ikke det nødvendigvis en svakhet ved programmet. Ledelse som fag og ledelse som praksis krever erfaring og prøvelser hos den enkelte for å få sin form. Læringsverdien i hvordan personer lærer om seg selv, ikke bare hva de lærer om seg selv, kom i samtale med en av arrangørene frem som et 
litt underkommunisert mål ved programmet. Etter intervjuene våre å dømme, slår det i praksis ut som økt refleksivitet og selvbevissthet blant både mentee-er og mentorer om hvem de er og vil være som ledere. Dette speiler funn fra en annen, nylig studie av lederutdanning i idretten (Lumpkin \& Achen, 2019).

Hvis programmet i for stor grad blir en personlig utviklingsfabrikk, vil derimot hensikten med å knytte det til idrett, slik det er i dag, være synkende for organisasjonene som sender deltagere dit. Dette dilemmaet reflekteres i de overordnede målene med programmet, der eksempelvis mål 4 (av 4) lyder: «Ved slutten av programmet [mars 2020] skal det være definerte mål for videre lederengasjement i idretten for alle kandidatene forankret i eget organisasjonsledd.» Hvis personlighetsfokuset blir for dominerende, kan imidlertid utfallet bli at evnen til å forene personlig innsikt med organisatorisk endringskapasitet ikke utvikles i særlig grad. I så fall vil programmet neppe svare på verken mål 4, eller Skinner, Smith og Swansons påstand (2018) om at fremtidens idrettsledere vil måles på hvorvidt de har lyktes med å skape en entreprenørkultur. For å få til det må ledere dele risikoen med sine medarbeidere, kommunisere at innovasjon representerer små skritt på en lang ferd (såkalt inkrementell innovasjon), og jobbe for at endring ikke bare betyr å forlate det gamle, men å lære noe nytt (Skinner, Smith \& Swanson, 2018, s. 97).

Programmet kan samtidig sies å ta høyde for sentrale deler av kritikken mot mentorprogrammer, blant annet Lebermans argument (2017) om at hvis programmer skal føre til endring, må de settes inn på et tidlig stadium av folks karriere. Spørsmålet er hvor tidlig. Et aldersspenn fra 19-29 år rommer ganske store variasjoner når det gjelder personlig modenhet og erfaringer man kan bygge på. En av informantene sa det slik: «Noen kunne jeg vært mentor for!» Effektiv kobling av mentor-mentee som betingelse for vellykket program er også verdt å trekke frem, og styrker funn fra tidligere forsking (Beres \& Dixon, 2014). Likevel er det flere av de seks typene med kritikk mot mentorprogrammer som ikke er tatt høyde for. Det gjelder i første rekke en risiko for en instrumentalisering av programinnholdet. Det står eksempelvis i NIF/NIS sitt program at målsettingen er at kandidatene «er mer effektive og har større gjennomslagskraft $i$ sitt verv etter deltakelse i mentorprogrammet» (kursiv lagt til), noe flere av 
informantene pekte på som potensielt problematisk da de egentlig ikke var der på vegne av sin organisasjon, men seg selv. At kjønnsperspektiver ikke var en del av programmet kan delvis forklares med at NIF/NSI har et eget mentorprogram for unge kvinnelige ledere, men samtidig kan det argumenteres for at det nettopp er mannlige deltagere som trenger den type ledelsesrefleksjoner. Arrangørene påpekte dessuten at et kjønnsnøytralt program var bedre egnet til å ta opp temaer og problemstillinger knyttet til personlig lederutvikling, hvilket kan diskuteres.

Til tross for noen svakheter når det gjelder sikring av hensikten med programmet som bør tas hensyn til ved neste korsvei, tilbyr programmet et svar på hva forskningsprosjektet «New Age of Sport Management Education in Europe» (NASME, 2019) fremhever som ettertraktede egenskaper ved fremtidige idrettsledere. Basert på en studie av ni land fant forskerne 72 kompetansekategorier, hvorav lagarbeid, beslutningsegenskaper og kommunikasjon fremsto som viktigst. Ledelse er i liten grad synlig i denne oversikten. Dette kan imidlertid ha sin forklaring i at «ledelse» i rapporten forstås i vel snever forstand. En bred forståelse, slik både vi og mentorprogrammet legger til grunn, vil derimot kunne inkludere alle de 72 kompetanseområdene som del av lederfaglig kompetanse, ikke minst når det kommer til det rapporten kaller «soft skills». I norsk sammenheng er dette relevant å forske videre på med tanke på idrettens endringer, og særlig hvis problemstillingene knyttes til mangfold, idrettsgren eller ledernivå (se for eksempel Hanstad, 2019, Hovden, 2010).

\section{Referanser}

Allen, T. D., Finkelstein, L. M. \& Poteet, M. L. (2009). Designing workplace mentoring programs: An evidence-based approach. Malden, MA: Wiley-Blackwell. https://doi.org/10.1002/9781444310320

Beres, J. L. \& Dixon, J. C. (2014). Exploring mentoring functions within the sport management academy: Perspectives of mentors and protégés. Sport Management Education Journal, 8(1), 14-26. https://doi.org/10.1123/smej.2012-0007

Birkinshaw, J., Zimmermann, A. \& Raisch, S. (2016). How do firms adapt to discontinuous change? Bridging the dynamic capabilities and ambidexterity perspectives. California Management Review, 58(4), 36-58. https://doi.org/10.1525/ cmr.2016.58.4.36 
Bower, G. G. (2009). Group mentoring as an alternative model for women. Women in Sport and Physical Activity Journal, 18(2), 80-84. https://doi.org/10.1123/ wspaj.18.2.80

Burke, R. J., Burgess, Z. \& Fallon, B. (2006). Benefits of mentoring to Australian early career women managers and professionals. Equal Opportunities International, 25(1), 71-79. https://doi.org/10.1108/02610150610645986

Chelladurai, P. (1990). Leadership in sports: A review. International Journal of Sports Psychology, 21(4), 328-354.

Chelladurai, P. \& Kerwin, S. (2018). Human resource management in sport and recreation (3. utg). Champaign, IL: Human Kinetics.

Chester, M. N. \& Mondello, M. (2012). Mentorship among female sport management doctoral students. Sport Management Education Journal, 6(1), 53-68. https://doi. org/10.1123/smej.6.1.53

Clutterbuck, D. (2003). The problem with research in mentoring [Paper, Coaching and Mentoring International Ltd]. Hentet fra https:// coachingandmentoringinternational.org/wp-content/uploads/CMI-Article-Theproblems-with-research-in-mentoring.pdf

Clutterbuck, D., Kochan, F., Lunsford, L. G., Dominguez, N. \& Haddock-Millar, J. (2017). Introduction. I D. Clutterbuck, F. Kochan, L. G. Lunsford, N. Dominguez \& J. Haddock-Millar (Red.), The SAGE handbook of mentoring (1-11). London: Sage. http://dx.doi.org/10.4135/9781526402011

Colley, H. (2003). Mentoring for social inclusion: A critical approach to nurturing mentor relationships. London: Routledge.

Comeaux, E. (2010). Mentoring as an intervention strategy. Journal for the Study of Sports and Athletes in Education, 4(3), 257-275. https://doi.org/10.1179/ ssa.2010.4.3.257

Duncan, R. B. (1976). The ambidextrous organization: Designing dual structures for innovation. I R. H. Kilmann, L. R. Pondy \& D. Slecin (Red.), The management of organization (Bd. 1, s. 167-188). New York: North-Holland.

Eby, L. T., Allen, T. D., Evans, S. C., Ng, T. \& Dubois, D. (2008). Does mentoring matter? A multidisciplinary meta-analysis comparing mentored and nonmentored individuals. Journal of Vocational Behavior, 72(2), 254-267. https://doi. org/10.1016/j.jvb.2007.04.005

Ekeland, J. (2014). Mentoring. Loerende allianser i ledelse. Bergen: Fagbokforlaget.

Eldridge, F. \& Dembkowski, S. (2016). Behavioral coaching. I J. Passmore, D. Peterson \& T. Freire (Red.), The Wiley-Blackwell handbook of the psychology of coaching and mentoring (s. 298-318). Oxford: Blackwell. https://doi. org/10.1002/9781118326459.ch16

Ferkins, L., Skinner, J. \& Swanson, S. (2018a). Sport leadership: A new generation of thinking. Journal of Sport Management, 32(2), 77-81. https://doi.org/10.1123/ jsm.2018-0054 
Ferkins, L., Skinner, J. \& Swanson, S. (2018b). Fostering innovative cultures in sport leadership, innovation and change. Cham: PalgraveMacmillan. https://doi.org/ 10.1007/978-3-319-78622-3

Hale, M. M. (1995). Mentoring women in organizations: Practice in search of theory. American Review of Public Administration, 25(4), 327-339. https://doi. org/10.1177/027507409502500402

Hanstad, D. V. (2019). Organisasjon og ledelse i idretten. Bergen: Fagbokforlaget.

Hegstad, C. D. \& Wentling, R. M. (2004). The development and maintenance of exemplary formal mentoring programs in fortune 500 companies. Human Resource Development Quarterly, 15(4), 421-448. https://doi.org/10.1002/ hrdq. 1114

Hovden, J. (2010). Female top leaders - prisoners of gender? The gendering of leadership discourses in Norwegian sports organizations. International Journal of Sport Policy and Politics, 2(2), 189-203. https://doi.org/10.1080/19406940.2010. 488065

Høigaard, R. \& Mathisen, P. (2009). Benefits of formal mentoring for female leaders. International Journal of Evidence Based Coaching and Mentoring, 7(2), 64-70.

Jones, R. L., Harris, R. \& Miles, A. (2009). Mentoring in sports coaching: A review of the literature. Physical Education and Sport Pedagogy, 14(3), 267-284. https:// doi.org/10.1080/17408980801976569

Kanter, R. M. (1977). Men and women of the corporation. New York: Basic Books. Kochan, F. K., Kent, A. M. \& Green, A. M. (Red.). (2015). Uncovering the cultural dynamics in mentoring programs and relationships. Charlotte, NC: Information Age Publishing.

Kram, K. E. (1983). Phases of the mentor relationship. Academy of Management Journal 26(4), 608-625. https://doi.org/10.5465/255910

Kram, K. E. (1985). Improving the mentoring process. Training and Development. $39(4), 40-43$.

Leberman, S. (2017). Future sport leaders: Developing young women to lead. I L. J. Burton \& S. Leberman (Red.), Women in sport leadership: Research and practice for change (s. 116-130). London: Routledge. https://doi.org/10.4324/ 9781315542775

Leeder, T. \& Cushion, C. (2019, 27. august). The reproduction of 'coaching culture': A Bourdieusian analysis of a formalised coach mentoring programme. Sports Coaching Review, https://doi.org/10.1080/21640629.2019.1657681

Levinthal D. A. \& March J. G. (1993). The myopia of learning. Strategic Management Journal, 14, 95-112. https://doi.org/10.1002/smj.4250141009

Lumpkin, A. \& Achen, R. M. (2019). Leadership education: Assessment of learning in a sport leadership course. Journal of Leadership Education, 18(2), 95-110. https://doi.org/10.12806/V18/I2/R7 
Megheirkouni, M. (2017). Leadership competencies: Qualitative insight into nonprofit sport organisations. International Journal of Public Leadership, 13(3), 166-181. https://doi.org/10.1108/IJPL-11-2016-0047

Merrick, L. (2017). Design of effective mentoring programs. I D. Clutterbuck, F. Kochan, L. G. Lunsford, N. Dominguez \& J. Haddock-Millar (Red.), The SAGE handbook of mentoring (s. 185-202). London: Sage. http://dx.doi. org/10.4135/9781526402011.n12

Merton, R. K. \& Kendall, P. L. (1946). The focused interview. American Journal of Sociology, 51(6), 541-557. https://doi.org/10.1086/219886

Merton, R. K., Fiske, M. \& Kendall, P. L. (1990). The focused interview: A manual of problems and procedures (2. utg.). New York: Free Press.

NASME. (2019). New age of sport management education in Europe (Sluttrapport). Hentet fra https://3456oe7a-63fc-467f-9ec3-8c9554ad7146.filesusr.com/ugd/ dbfboo_072ao7414679444f8f9occ2d22ba5bie.pdf

Næss, H. E. (2019). Godt styresett i Norges Idrettsforbund. En dokumentanalyse av Åpenhetsutvalgets rapport. Scandinavian Sport Studies Forum, 10, 177-199. https://sportstudies.org/wp-content/uploads/2019/10/sssf_177-199_vol_10_2019_ naess.pdf

O’Reilly, C. A. \& Tushman, M. L. (2008). Ambidexterity as a dynamic capability: Resolving the innovator's dilemma. Research in Organizational Behavior, 28, 185-206. https://doi.org/10.1016/j.riob.2008.06.002

O'Reilly, C. A. \& Tushman, M. L. (2011). Organizational ambidexterity in action: How managers explore and exploit. California Management Review, 53(4), 4-22. https://doi.org/10.1525/cmr.2011.53.4.5

Peachey, J. W., Damon, Z. J., Zhou, Y. \& Burton, L. J. (2015). Forty years of leadership research in sport management: A review, synthesis, and conceptual framework. Journal of Sport Management, 29(5), 570-587. https://doi.org/10.1123/jsm.20140126

Pfister, G. \& Radtke, S. (2009). Sport, women, and leadership: Results of a project on executives in German sports organizations. European Journal of Sport Science, 9(4), 229-243. https://doi.org/10.1080/17461390902818286

Sands, R. G., Parson, L. A. \& Duane, J. (1991). Faculty-faculty mentoring and discrimination. Equity \& Excellence in Education, 25(2-4), 124-129. https://doi. org/10.1080/1066568910250219

Skinner, J., Smith, A. C. T. \& Swanson, S. (2018). Fostering innovative cultures in sport. Leadership, innovation and change. Cham: Palgrave Macmillan. https://doi. org/10.1007/978-3-319-78622-3

Stalker, J. (1994). Athene in academe: Women mentoring women in the academy. International Journal of Lifelong Education, 13(5), 361-372. https://doi. org/10.1080/0260137940130503 
Tjora, A. (2017). Kvalitative forskningsmetoder i praksis (3. utg.). Oslo: Gyldendal Akademisk.

Underhill, C. (2006). The effectiveness of mentoring programs in corporate settings: A meta-analytical review of the literature. Journal of Vocational Behavior, 68(2), 292-307. https://doi.org/10.1016/j.jvb.2005.05.003

Weaver, M. A. \& Chelladurai, P. (1999). A mentoring model for management in sport and physical education. Quest, 51(1), 24-38. https://doi.org/10.1080/00336297. 1999.10491666 



\title{
KAPITTEL 9
}

\section{Arbeidsinkludering: En organisatorisk diamant}

\author{
Mari Svendsen \\ Hoyskolen Kristiania \\ Ola Martin Jensen Larsen \\ Hoyskolen Kristiania
}

\begin{abstract}
Increased work-life exclusion of individuals with limited working abilities or special needs as a result of physical, mental or linguistic limitations is a significant societal challenge. Work inclusion is highlighted as the most effective measure for solving this challenge. In this context, work inclusion is defined as the inclusion of individuals with reduced work capacity or increased facilitation needs in ordinary workplaces. Research on work inclusion has mainly focused on what it takes for vulnerable individuals to succeed in organisational life. However, there is limited knowledge on the potential effects of work inclusion for organisations as a whole. This chapter seeks to expand the knowledge regarding these potential effects. Therefore, we take a closer look at how work inclusion affects ordinary employees motivation, commitment, leadership abilities, work environment and organisational success. By combining existing litterature from different fields of research, we have developed a preliminary theoretical framework and a model that illustrates the positive internal effects of work inclusion. This chapter will therefore contribute to greater understanding of how work inclusion can be a strategic tool for providing positive development for organisations.
\end{abstract}

Keywords: work inclusion, leadership, motivation, organizational success, commitment

\section{Innledning}

I rapporten «Inkluder meg» (Norvoll, 2011) siteres en respondent som står utenfor arbeidslivet på følgende måte: «Mennesket har blitt knyttet mye mer opp til nytteverdi. [...] Det gjør at man måler sin verdi i hvor nyttig

Sitering av denne artikkelen: Svendsen, M. \& Larsen, O. M. J. (2020). Arbeidsinkludering: En organisatorisk diamant. I J. Bastesen, B. K. Lange, H. E. Næss \& A. N. Thon (Red.), Ledelse av mennesker $i$ det nye arbeidslivet (Kap. 9, s. 231-256). Oslo: Cappelen Damm Akademisk. https://doi.org/10.23865/noasp.118.ch9 Lisens: CC-BY 4.o. 
man er, hvor mye man produserer, hvor mye man får gjort og hvor bra det er» (Norvoll, 2011, s. 13). Dette sitatet peker på viktigheten av å være en del av et arbeidsfelleskap både for individet selv, og for bærekraftsevnen i samfunnsstrukturen vår.

Litteraturen rundt anvendt arbeidsinkludering strekker seg over flere forskningsområder, og bygger på forskning knyttet til inkluderingen av mennesker med spesielle behov på arbeidsplassen. Her inngår blant annet bruk av mentorer, fysisk tilrettelegging på arbeidsplassen og tett oppfølging fra relevante institusjoner (Kulkarni, Boehm \& Basu, 2016; Spjelkavik \& Thingbø-Støldal, 2014). Forskningen har hovedsakelig undersøkt hvordan organisasjonene best mulig kan tilrettelegge for de individene som skal inkluderes. Samtidig er det lite forskning som ser nærmere på hvilket utbytte organisasjoner, ledere og ordinært ansatte (kollegaer som ikke har samme grad av tilretteleggingsbehov) har som følge av arbeidsinkludering. Denne manglende kunnskapen er uheldig, fordi viten om hvordan arbeidsinkludering påvirker ulike nivåer i organisasjonen vil være nyttig for å motivere og trygge organisasjonene til å ta samfunnsansvar. Det vil også legge grunnlaget for utvidet kunnskap om hvordan vi kan arbeide strategisk med arbeidsinkludering for å oppnå positive effekter i organisasjonen.

Dette kapitlet forsøker derfor å bidra til dette lite utforskede området ved å formulere et begynnende teoretisk rammeverk for de organisatoriske effektene av arbeidsinkludering. Dette vil vi gjøre ved å utvikle en teoretisk modell som bidrar til å besvare følgende forskningsspørsmål: Hvordan påvirker arbeidsinkludering ulike nivåer i organisasjonen?

Først vil vi presentere en modell som kartlegger mulige effekter og gir mulighet for videre forskning på hvordan arbeidsinkludering påvirker organisasjonen. Nivåene i organisasjonen innbefatter:

a. Den enkelte ansatte - operasjonalisert som tilknytning og motivasjon

b. Gruppenivå - operasjonalisert som helsefremmende arbeidsmiljø

c. Mellomledernivå - operasjonalisert som lederutvikling

d. Overordnet organisatorisk nivå - operasjonalisert som organisatoriske prestasjoner. 
Videre vil sentrale moderatorer - det vil si faktorer som påvirker relasjonen mellom arbeidsinkludering og relevante effekter - bli presentert (se modell 1). Hensikten med vår foreslåtte teoretiske modell er ikke å gi et uttømmende rammeverk for samtlige mulige organisatoriske effekter av arbeidsinkludering, men snarere et begynnende teoretisk rammeverk og et fundament for fremtidige empiriske undersøkelser knyttet til arbeidsinkludering.

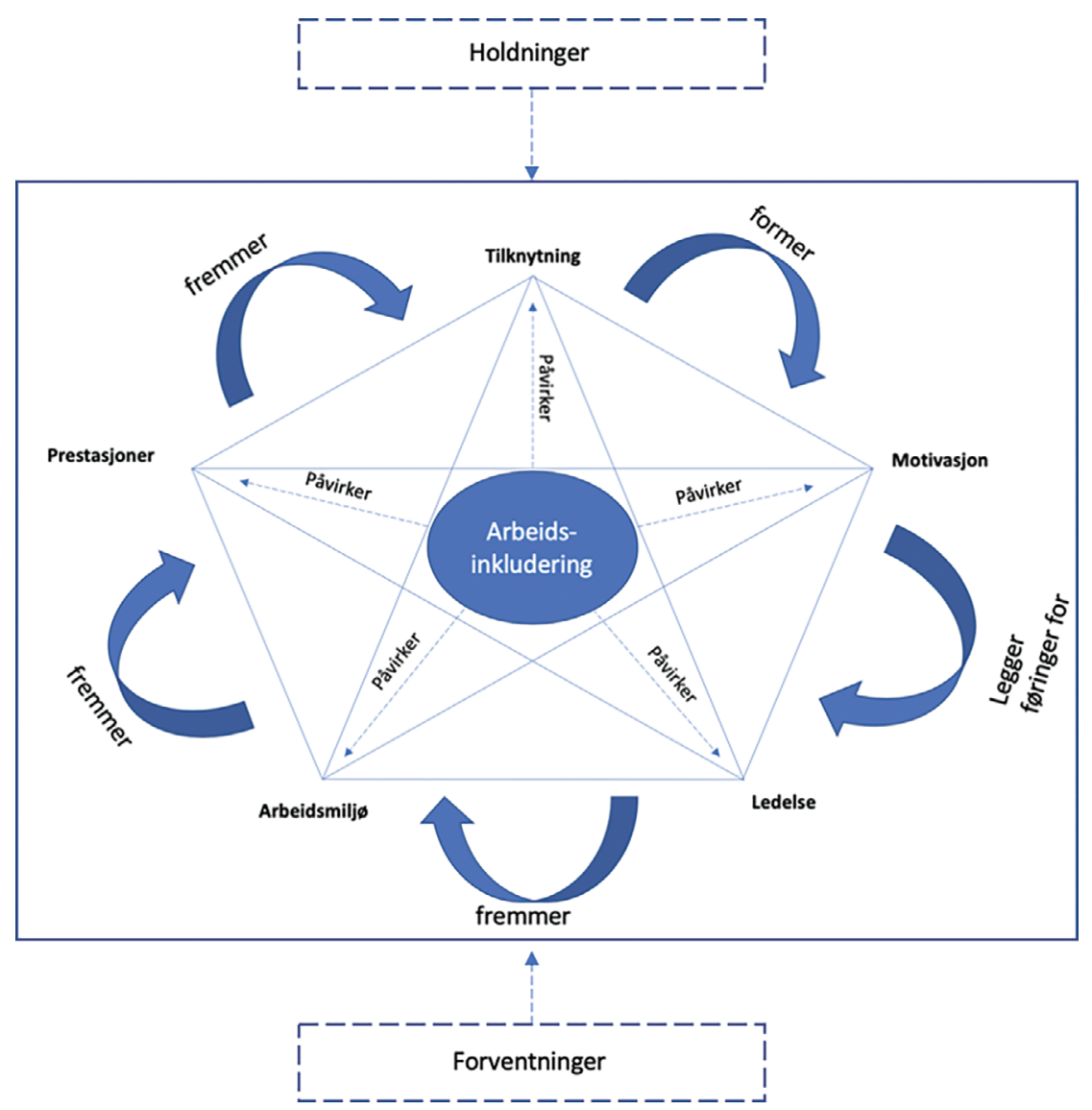

Modell 1. Inkluderingsdiamanten.

Modellen illustrerer hvordan arbeidsinkludering kan ha positiv påvirkning på fem ulike parametere i en organisasjon: Den enkeltes følelse av tilknytning til organisasjonen, motivasjon til å utføre arbeidsoppgavene, 
lederutvikling (spesielt på mellomledernivå), helsefremmende arbeidsmiljø samt organisatoriske prestasjoner. Potensiell effekt vises ved de stiplede pilene som går ut fra kjernen i modellen. Jo større effekt, jo mer utvides modellen, hvilket illustrerer organisasjonens vekst. Modellen vektlegger også sammenhengen mellom parameterne, og hvordan modellen vokser proporsjonalt på grunn av denne sammenhengen. Boksene over og under illustrerer tilhørende moderatorer, henholdsvis Holdninger til de som skal inkluderes og Forventninger til suksess. Disse moderatorene er illustrert med stiplede linjer, for å illustrere sammenhengen med de stiplede linjene (effektene av arbeidsinkludering) i modellen. Moderatorene definerer i hvor stor grad de ulike parametrene påvirkes av arbeidsinkluderingen. Kapitlet vil videre utdype modellen gjennom å presentere sju antakelser som forklarer de ulike delene i modellen.

Resten av kapitlet er bygd opp på følgende måte: Først vil betydningen av et arbeidsfellesskap bli utdypet, før den teoretiske konteksten kapitlet baserer seg på blir redegjort for. Deretter vil en teoretisk analyse av komponentene i modellen bli presentert, og faktorer som påvirker komponentene i kapitlet bli diskutert. Til sist vil de praktiske implikasjonene av kapitlet bli gjennomgått, og forslag til videre forskning på temaet vil bli presentert.

\section{Betydningen av et arbeidsfellesskap}

Arbeidsmiljøloven pålegger organisasjoner å legge til rette for medarbeidere med særegne behov, for eksempel funksjonshemninger eller annen kulturell bakgrunn. Likevel ser vi at flere faller utenfor det norske arbeidslivet, spesielt blant individer med psykisk sykdomshistorie, fysiske handicap eller ikke-vestlig bakgrunn (NAV, 2020; Statistisk sentralbyrå, 2019a, 2019b). De tilhørende samfunnsutfordringene som følger av dette utgjør en reell trussel mot velferdsstaten, da det øker marginaliseringen av ulike minoritetsgrupper og dermed øker graden av sosial urettferdighet. Fra et økonomisk perspektiv gjør den økte ekskluderingen fra arbeidsmarkedet samfunnsmodellen vår mindre bærekraftig gjennom økt trykk på de norske trygdeordningene (Frøyland \& Spjelkavik, 2014). Arbeidsledighet er også sterkt knyttet til redusert 
helsetilstand og livskvalitet for de ekskluderte individene (Anvik \& Gustavsen, 2012).

Både norsk og internasjonal forskning peker på arbeidsinkludering definert som «inkluderingen av individer med spesielle behov og/eller redusert arbeidskapasitet i det ordinære arbeidsliv» (Hernes, Heeum \& Haavorsen, 2010) - som det mest effektive tiltaket for både økt sysselsetting og å forhindre ekskludering fra både arbeidslivet og generelt i samfunnet. I denne konteksten defineres individer med spesielle behov eller redusert arbeidskapasitet som «individer som er sårbare for ekskludering fra arbeidslivet grunnet psykisk sykdom, sansehemninger, fysiske handicap eller språklige eller kulturelle utfordringer på grunn av immigrasjonsbakgrunn» (Frøyland \& Spjelkavik, 2014). Selv om inkludering av individer med spesielle behov i vanlige organisasjoner har vist seg å være det mest effektive tiltaket for å redusere ekskludering fra arbeidslivet, ligger mye av utfordringen i manglende motivasjon og trygghet til å gjennomføre arbeidsinkluderingstiltak i norske organisasjoner (Spjelkavik, Hagen \& Härkäpää, 2011).

Denne utfordringen er todelt, ettersom organisasjonene er opptatt av de positive eller negative effektene arbeidsinkludering kan ha på arbeidsmiljøet, og hvordan arbeidsinkludering påvirker effektiviteten i organisasjonen (Falkum, Schaft \& Spjelkavik, 2014). En kartlegging av faktiske effekter av arbeidsinkludering vil derfor være avgjørende for å sikre at organisasjoner er motiverte for å åpne for slike aktiviteter. Positive effekter vil gi organisasjonene et incentiv i seg selv, samtidig som synliggjøringen av negative effekter kan gi retningslinjer for hvordan organisasjonene klarer å styre unna utilsiktede utfall som følge av arbeidsinkludering.

\section{Teori}

\section{Teoretisk kontekst}

Formålet med kapitlet er å kombinere ulike teoretiske perspektiver for å danne oss et bilde av mulige organisatoriske effekter av arbeidsinkludering, illustrert gjennom Modell 1. Litteraturen som er utvalgt baserer seg på relevante oppsamlende studier, samt kvalitative og kvantitative studier innenfor de relevante fagområdene som belyser de teoretiske 
antagelsene i artikkelen. Studiene som kapitlet benytter er alle publisert i anerkjente og fagfellevurderte tidsskrifter, og er funnet gjennom et systematisk litteratursøk.

For det første baserer kapitlet seg på mangfoldslitteraturen. Mangfold i organisasjoner er ofte definert som en «betydelig formell eller uformell ulikhet som skiller ett individ fra et annet» (Jayne \& Dipboye, 2004). Dersom man legger denne definisjonen til grunn, vil den også inkludere individer med spesielle behov eller redusert arbeidskapasitet. Dermed gir mangfoldslitteraturen oss mange viktige perspektiver på hvordan inkludering av individer med ulik demografisk bakgrunn kan øke eller redusere organisasjoners effektivitet. Mangfoldslitteraturen har imidlertid hovedsaklig begrenset sitt fokus til ulike demografiske variabler som etnisk bakgrunn, alder og kjønn, og ikke utforsket hvordan arbeidsinkludering av individer med spesielle behov eller redusert arbeidskapasitet kan bidra ytterligere til organisatorisk utvikling- hvilket er målet for dette kapitlet. Med bakgrunn i dette er mangfoldslitteraturen et nyttig fundament å bygge ut fra, men trenger å suppleres av andre forskningsfelter for å gi et godt teoretisk grunnlag for dette kapitlet.

For det andre vil kapitlet benytte litteratur fra forskningen knyttet til Corporate Social Responsibility (CSR). Fordi ansattes holdninger er påvirket mer av hvordan individet opplever organisatoriske handlinger enn hva organisasjonen faktisk gjør, legger vi vekt på de ansattes opplevelse av CSR, fremfor de konkrete CSR-initiativenes innhold (Rupp, Ganapathi, Aguilera \& Williams, 2006). Vi definerer derfor CSR i tråd med El Akremi et al., som beskriver CSR som «organisasjonens kontekst-spesifikke handlinger og retningslinjer, som sikter på å øke velstanden til relevante interessenter gjennom å ta hensyn til den triple bunnlinjen som involverer både økonomiske, sosiale og miljømessige prestasjoner» (El Akremi, Gond, Swaen, De Roeck \& Igalens, 2018, vår oversettelse). Arbeidsinkludering kan forstås som en sosial del av bunnlinjen til organisasjoner, selv om det eksisterer lite forskning på området. I tråd med dette vil arbeidsinkludering av individer med spesielle behov kunne gi mange av de samme positive organisatoriske effektene som CSR-litteraturen viser til, ved å gi ansatte følelsen av å ta sosialt ansvar (Bergsteiner \& Avery, 2010). Likevel, arbeidsinkludering er fremdeles 
ikke anerkjent som et viktig område for forskning innen dette feltet, noe vi ønsker å stimulere til gjennom dette kapitlet.

For det tredje anerkjenner vi viktigheten av arbeidet knyttet til forskning gjort på arbeidsinkludering i praksis, for eksempel innen felt som «supported employment» (Rusch, 1990). Denne litteraturen har imidlertid blikket rettet mot hvordan organisatoriske parametere påvirker suksessen for den enkelte som skal inkluderes, og ikke mot hvordan den inkluderte påvirker organisatoriske parametere. Hensikten med kapitlet er å bidra til å tette dette forskningsgapet gjennom en teoretisk analyse av hvordan arbeidsinkludering påvirker ulike deler av organisasjonen.

For det fjerde bygger kapitlet på organisasjonspsykologien generelt, hvor vi ønsker å kombinere ovennevnte litteratur med forskning på ansattes holdninger, identitet, motivasjon, psykososialt arbeidsmiljø og ledelse.

\section{Organisatoriske effekter av arbeidsinkludering}

Vårt fokus er på effekter av arbeidsinkludering på individnivå, gruppenivå, ledernivå og organisasjonsnivå. Med utgangspunkt i Burke og Litwin (1992) sin modell for organisatoriske prestasjoner har vi valgt å fokusere på jobbmotivasjon og tilknytning på individnivå, lederutvikling på ledernivå, arbeidsmiljø på gruppenivå og hvordan disse faktorene relaterer seg til organisatoriske prestasjoner på organisasjonsnivå. Med unntak av tilknytning er dette parametre som Burke og Litwin (1992) fremholder som sentrale transaksjonelle faktorer for organisatoriske prestasjoner, og disse parametrene vil derfor danne kapitlets rammeverk. Tilknytning til organisasjonen er i tillegg tatt med på individnivå grunnet den sterke sammenhengen med jobbmotivasjon. Transaksjonelle faktorer forstås i Burke og Litwin (1992) sin modell som aspekter ved organisasjonen som skaper små forandringer på en daglig basis, i motsetning til de transformerende faktorene som skaper store og gjennomgripende endringer. Disse transaksjonelle faktorene er derfor særlig relevante i forbindelse med arbeidsinkludering, som vi argumenterer for at skaper endringer i de ulike organisatoriske nivåene gjennom en langsom, dynamisk prosess. Vi vil derfor se nærmere på hvordan arbeidsinkludering kan gi organisatoriske effekter på de ulike nivåene. 


\section{Individnivå: Effekter på organisatorisk tilknytning og indre motivasjon}

Inkludering av individer med nedsatt arbeidsevne eller særlige tilretteleggingsbehov kan påvirke både individets jobbmotivasjon og tilknytning til organisasjonen. Vårt primære argument er at arbeidsinkludering bidrar til økt indre motivasjon hos ansatte også utover dem som inkluderes, blant annet gjennom å skape en sterkere tilknytning til organisasjonen. Indre motivasjon forstås i tråd med Deci og Ryan (1985, vår overs.) som «motivasjon hvor den ansatte opplever at aktiviteten han eller hun utfører er verdifull i seg selv». Indre motivasjon er viktig, da det er relatert til økte prestasjoner og innsats samt velvære hos de ansatte (Deci \& Ryan, 2002). Organisatorisk tilknytning («organisational commitment») defineres som graden av medarbeiderens identifisering med og involvering $\mathrm{i}$ organisasjonen (Mowday, Porter \& Steers, 1982), og har en sterk relasjon til indre jobbmotivasjon (Kuvaas, Buch, Weibel, Dysvik \& Nerstad, 2017).

Arbeidsinkludering påvirker de ansattes organisatoriske tilknytning og indre motivasjon gjennom en økt opplevelse av CSR i organisasjonen. Dette oppstår ved at bedriften viser overfor de ansatte at de tar del i å løse et viktig samfunnsproblem - her forstått som arbeidsekskludering - og bidrar dermed også til å styrke det sosiale aspektet i den «tredelte bunnlinjen». Forskning innenfor CSR-området bekrefter dette, og viser til at opplevelsen av at egen organisasjon tar sosialt ansvar har en positiv påvirkning på individets organisatoriske tilknytning og jobbmotivasjon (Downey, Werff, Thomas \& Plaut, 2014; Kim \& Scullion, 2013).

Fra forskning på sosial identitetsteori vet vi at individer ønsker å identifisere seg med grupper som bidrar positivt til eget selvkonsept (Tajfel \& Turner, 1985). Et individs selvkonsept er individets kognitive forståelse av seg selv. Selvkonseptet danner grunnlaget for individets selvfølelse, og dermed individets vurdering av egenverd. Organisasjoner som jobber strategisk med arbeidsinkludering vil i større grad bli vurdert som attraktive å identifisere seg med av egne ansatte. Individet vil dermed oppfatte organisasjonens suksess som sin egen suksess, og ønsker derfor å handle på en måte som bidrar positivt for organisasjonen. Organisasjonen oppfattes dermed som en del av de ansattes selvkonsept, og fører til økt organisatorisk tilknytning gjennom sosial identifisering og 238 
tilhørende indre motivasjon hos den ansatte (Ashforth \& Mael, 1987; Shamir, House \& Arthur, 1993).

Arbeidsinkludering kan også ha en positiv effekt på indre motivasjon gjennom tilhørighet. Å skape tilhørighet er et viktig element innen både CSR-teori, mangfoldslitteraturen og motivasjonspsykologien (McClelland, 1984; Ryan \& Deci, 1985, 2002). Virkeligheten viser imidlertid at det kan være svært vanskelig å skape bred anerkjennelse og tilhørighet hos egne arbeidstakere. Tilhørighet skapes gjennom sosial aksept for den enkelte, og at den enkelte får «komme inn i varmen». De vanligste metodene for å skape tilhørighet er ved å anerkjenne den enkelte arbeidstaker ut over gjennomføringen av de tilhørende arbeidsoppgavene, vise empati og ved å definere verdier og målsettinger som den enkelte kan relatere til (Govier, 1999). Dersom arbeidstakerne selv får muligheten til å være ambassadører for tilhørighetsskapende aktivitet for individer som er del av et arbeidsinkluderingsinitiativ, vil det også kunne påvirke deres opplevelse av tilhørighet. Ved å la arbeidstakere aktivt ta del i arbeidsinkluderingsinitiativer, kan det i seg selv generere økt tilhørighet for organisasjonens ordinære arbeidstakere.

Fra et organisasjonspsykologisk perspektiv vil også inkludering av individer med nedsatt arbeidsevne kunne påvirke den ansattes opplevelse av positiv meningsfullhet med arbeidet. Positiv meningsfullhet defineres i jobbsammenheng som at «arbeidet representerer en verdifull og konstruktiv aktivitet for den ansatte» (Wrzesniewski, LoBuglio, Dutton \& Berg, 2013, s. 288, vår overs.) og er relatert til positive konstrukter som ekstrarolleatferd, indre motivasjon, organisatorisk tilknytning og jobbtilfredshet (Maharaj \& Schlechter, 2007). Litteraturen rundt meningsfullhet viser at ansatte som føler de bidrar til noe som oppleves større enn dem selv og som er i tråd med deres verdier, opplever større positiv mening på arbeidet (Maharaj \& Schlechter, 2007). Arbeidsinkludering representerer en slik aktivitet, og kan gi opplevelsen av at man bidrar til å redusere utenforskap samtidig som det øker livskvaliteten hos enkeltindivider. Dette bidrar til å styrke både den indre motivasjonen og organisatoriske tilknytningen hos involverte arbeidstakere.

Oppsummert ser vi at arbeidsinkludering kan føre til sterkere tilknytning og indre motivasjon hos den ansatte ved at medarbeideren opplever 
at bedriften tar sosialt ansvar gjennom økt sosial identitet, økt tilhørighet og gjennom økt meningsfullhet i arbeidet. Dette leder til antakelse 1 og 2:

a1: Arbeidsinkludering fører til sterkere organisatorisk tilknytning

a2: Arbeidsinkludering fører til sterkere indre motivasjon hos de ansatte.

\section{Gruppenivå: Effekter på arbeidsmiljø}

I senere år har søkelyset på forbedring av arbeidsmiljøet blitt flyttet fra å ensidig handle om sykefravær, til i større grad å utforske hva som holder medarbeiderne i organisasjoner friske (Hanson, 2007). Dette helsefremmende perspektivet ser på hvilke ressurser ved arbeidsplassen som kan støtte ansatte og deres ledere i å opprettholde og forbedre fysisk og psykisk helse, oppnå mål på jobben, bidra til personlig utvikling samt en kartlegging og handlingsplan for viktige risikofaktorer på arbeidsplassen (Hanson, 2007). Arbeidsinkludering kan bidra til helsefremming på arbeidsplassen på ulike måter.

For det første kan arbeidsinkludering bidra til å redusere og identifisere viktige risikofaktorer på arbeidsplassen. Eksempelvis kan tilrettelegging for individer med fysiske handicap også ha positive spillover-effekter på resten av arbeidsgruppen. Tilrettelegginger for personer med vondt $\mathrm{i}$ ryggen vil kunne øke bevisstheten rundt tilrettelegging også for andre, og dermed være med på å redusere ryggsmerter og medfølgende sykefravær hos de øvrige ansatte. Gjennom å tilrettelegge for den inkluderte ved å forbedre arbeidshverdagen ergonomisk, blir man også oppmerksom på denne risikofaktoren på resten av arbeidsplassen. Dette bidrar til å redusere sannsynligheten for plager relatert til dårlig arbeidsstilling for de øvrige ansatte. Arbeidsinkludering kan derfor bidra til et mer helsefremmende arbeidsmiljø.

For det andre kan arbeidsinkludering bidra til større åpenhet og mindre stigmatisering på arbeidsplassen (Ramvi, Skarpaas \& Løvereide, 2013). Arbeidsinkludering av arbeidstakere med psykisk sykdom kan gjøre det lettere å snakke om psykisk helse, definere risikofaktorer og normalisere psykisk sykdom på arbeidsplassen, definere risikofaktorer for psykisk sykdom og normalisere og legitimere fokuset på psykisk helse 
på arbeidsplassen. Arbeidsplassen er et viktig sted for forbedring og forebygging av psykisk sykdom, og det å få oppmerksomhet rundt dette gjennom arbeidsinkludering vil kunne skape positive effekter også for resten av arbeidsgruppen (Aronsson \& Lindh, 2004).

For det tredje kan arbeidsinkludering bidra positivt til opplevelsen av det organisatoriske klimaet, på tvers av alle nivåer i organisasjonen. Det helsefremmende gruppeklimaet er ifølge DeJoy og Wilson bestemt av opplevelsen den ansatte har av hvordan kommunikasjonen foregår og det generelle sosiale/interpersonelle klimaet på arbeidsplassen (2003). Arbeidsinkludering kan bidra positivt til dette, da vellykket inkludering av arbeidstakere med særegne behov fordrer tydelig og anerkjennende kommunikasjon (Frøyland \& Spjelkavik, 2014). Fokus på arbeidsinkludering kan dermed også føre til at arbeidsgruppen kommuniserer mer effektivt og med større grad av anerkjennelse enn tidligere. I tråd med dette kan arbeidsinkludering gjennom forbedret kommunikasjon, større takhøyde for meningsytringer og mer åpenhet også bidra til bedre samspill mellom medlemmene av arbeidsgruppen.

Oppsummert ser vi at arbeidsinkludering kan ha en helsefremmende og positiv effekt på arbeidsmiljøet gjennom å rette oppmerksomheten mot fysiske og psykiske risikofaktorer i organisasjonen, og bidra til mer åpenhet og mindre stigmatisering. Antakelse 3 blir derfor:

a3: Arbeidsinkludering har en helsefremmende effekt på arbeidsmiljøet.

\section{Effekter på ledernivå: Lederutvikling}

Basert på perspektiver fra ledelseslitteraturen argumenterer vi for at arbeidsinkludering kan bidra til lederutvikling. Lederutvikling forstås som en utvidelse av individets kapasitet til å være effektiv i lederrollen og prosesser (Day \& Thornton, 2017). Vårt fokus ligger først og fremst på mellomledere som står med ansvaret for gjennomføring, oppfølging og evaluering av arbeidsinkluderingtiltak, samt personalansvaret for de som inkluderes gjennom disse tiltakene. Hva som er viktig å utvikle hos mellomledere og ledere generelt er et mye diskutert tema i ledelseslitteraturen (Antonakis, Cianciolo \& Sternberg, 2004). Eksisterende teori knytter 
lederutvikling gjennom særskilt tilrettelegging til konkrete ferdigheter som for eksempel aktiv lytting, men også mer generelle egenskaper og mentale prosesser, som eksempelvis evnen til selvledelse, lederidentitet og evnen til å skape gode sosiale relasjoner (Mumford, Campion \& Morgeson, 2007; McCauley \& Van Velsor, 2003). Vi argumenterer derfor for at arbeidsinkludering kan bidra til utvikling av både konkrete ferdigheter og generelle egenskaper hos mellomlederen.

Først og fremst kan arbeidsinkludering bidra til utviklingen av forbedrede kommunikasjonsevner. Ramvi og Farstad (2011) viser til at mellomledere opplever forbedrede kommunikasjonsevner som følge av arbeidsinkluderingsansvar. Å lede et individ med tilretteleggingsbehov eller nedsatt arbeidsevne krever tydelig kommunikasjon av forventninger til både mellomleder og den inkluderte, samt et økt behov hos arbeidstakeren for anerkjennelse og tilbakemelding på løste oppgaver. I tillegg til egenverdien av forbedrede kommunikasjonsevner hos lederen, legger det også grunnlaget for videre utviklingspotensiale gjennom blant annet økt forståelse for den enkeltes behov og økt formidlingsevne. Ramvi og Farstad (2011) indikerer dermed at det ligger betydelig utviklingspotensiale for ledere $i$ arbeidsinkluderingsinitiativer.

Arbeidsinkludering kan også ha effekter på mer generelle evner og mentale prosesser hos lederen. Eksempelvis viste studiet av Ramvi og Farstad (2011) at ledere med ansvar for ansatte med tilretteleggingsbehov eller nedsatt arbeidsevne utfordres på hvordan de kan skape mestringsfølelse for disse medarbeiderne. Ansatte med nedsatt arbeidsevne eller tilretteleggingsbehov kan ha større behov for at arbeidsoppgavene tilpasses den enkelte arbeidstakers ferdigheter og interesser. Arbeidsinkludering kan derfor bidra til forbedrede evner til individuell hensyntagen (Bass, 1985), og videre stimulere mellomledere til å skape mestringsopplevelser hos sine ansatte.

Oppsummert ser vi derfor at arbeidsinkludering kan bidra til å utvikle både konkrete ferdigheter og mer generelle egenskaper hos mellomledere. Antakelse 4 blir derfor:

a4: Arbeidsinkludering har en positiv effekt på utvikling av mellomledere. 


\section{Effekter på organisatoriske prestasjoner}

Organisatoriske prestasjoner defineres ifølge Yukl \& Mahsud som i hvilken grad organisasjonen har tilstrekkelig effektivitet, innovasjon og menneskelig kapital (2010). Vårt argument er at arbeidsinkludering bidrar til økte organisatoriske prestasjoner gjennom en styrking av menneskelig kapital gjennom økt indre motivasjon, sterkere tilknytning, forbedrede lederegenskaper og mer helsefremmende arbeidsmiljø. Med utgangspunkt i modellen til Burke og Litwin (1992) har vi valgt å se på jobbmotivasjon, arbeidsmiljø og lederutvikling i vår analyse av den menneskelige kapitalen i organisasjonen. I kapitlet er det argumentert for hvordan arbeidsinkludering kan føre til økt motivasjon, lederutvikling og et mer helsefremmende arbeidsmiljø. Litteraturen viser at det er en positiv sammenheng mellom organisatorisk tilknytning og organisatoriske prestasjoner (William \& Anderson, 1991) jobbmotivasjon og organisatoriske prestasjoner (Joseph, 2014), mellom effektive lederprosesser og organisatoriske prestasjoner (Yukl, 2008) og mellom helsefremmende arbeidsmiljø og organisatoriske prestasjoner (Lowe, Schellenberg \& Shannon, 2003). Vi argumenterer derfor for at arbeidsinkludering fører til økt jobbmotivasjon, lederutvikling og arbeidsmiljø, som igjen medierer effekten på organisasjonens prestasjoner. Vi presiserer at det er en delvis mediasjon, da andre medierende variabler også kan være relevante i sammenhengen. Antakelse 5 blir derfor:

a5: Arbeidsinkludering fører til forbedrede organisatoriske prestasjoner. Denne effekten er delvis mediert av jobbmotivasjon, lederutvikling og helsefremmende arbeidsmiljø.

\section{Faktorer som påvirker i hvilken grad arbeidsinkludering har en positiv effekt i organisasjonen}

Mangfoldslitteraturen viser at mangfold i organisasjoner kan ha både positive og negative effekter, avhengig av ulike interne og eksterne faktorer (Pugh, Dietz, Brief \& Wiley, 2008). Eksterne faktorer kan være 
størrelse på organisasjonen, ansiennitet i organisasjonen, type organisasjon og diversiteten i miljøet som omgir organisasjonen (Pugh et al., 2008). Selv om dette er viktige faktorer, er ulempen at man har liten eller ingen påvirkningskraft når det kommer til eksterne og/eller strukturelle faktorer. Vi ser derfor bort fra eksterne faktorer i denne sammenheng, og fokuserer på de interne organisatoriske faktorene i dette kapitlet.

I de neste avsnittene vil vi se nærmere på to interne og psykologiske faktorer som vil kunne påvirke om arbeidsinkludering får en positiv eller negativ innvirkning på motivasjon, arbeidsmiljø og lederutvikling. Formålet er å vise hvordan spesielt de to psykologiske faktorene holdninger og forventninger (se modell 1) kan påvirke om arbeidsinkludering bidrar eller hindrer til positive effekter i organisasjonen.

\section{Holdninger}

Holdninger forstås i denne konteksten bredt som «en psykologisk tendens som blir uttrykt gjennom en evaluering av en person eller gruppe som enten positiv eller negativ» (Eagly \& Chaiken, 1993, s. 1, vår overs.) Basert på mangfoldslitteraturen vet vi at individets positive holdninger til ulike sosiale grupper, basert på for eksempel kjønn eller alder, er avgjørende for om mangfoldstiltak får en positiv effekt i organisasjonen. En studie av Kossek og Zonia (1993) viser at holdningene de ansatte hadde til etniske grupper hadde avgjørende betydning for om inkluderingen av disse ble oppfattet som positivt hos enkeltindividet. Basert på funnene fra denne studien vil det være naturlig å anta at det vil være større sannsynlighet for at inkludering av en arbeidstaker med psykisk sykdom vil skape positive effekter dersom miljøet rundt anerkjenner psykisk sykdom, og følgelig ikke har en holdning der de mener individer med psykisk sykdom eksempelvis bare må «ta seg sammen». Om ordinære ansatte har en positiv holdning til den inkluderte arbeidstakeren, vil organisasjonen også bli mer attraktiv å identifisere seg med, da den inkluderte arbeidstakeren kan bli en del av inngruppen - her ment som det eksisterende arbeidsfellesskapet. Motsatt vil inngruppen bli lite attraktiv å identifisere seg med hvis arbeidstakeren har en negativ holdning til den inkluderte 
gruppen, og dermed vil arbeidsinkludering kunne påvirke motivasjonen hos arbeidstakeren negativt (Tajfel \& Turner, 1985).

På samme måte vil også opplevelsen av meningsfullhet bli større hvis man inkluderer noen fra en sosial gruppe som man har en positiv holdning til, da dette i større grad er i tråd med de grunnleggende verdiene hos den ansatte. På den annen side vil meningsfullheten bli mindre eller påvirkes negativt hvis man har en lite positiv holdning til den inkluderte arbeidstakeren, da dette vil kunne gå på tvers av den ordinært ansattes verdier og holdninger (Aguinis \& Glavas, 2019). Dette gjelder spesielt på ledernivå, da en leder med en positiv holdning til den inkluderte vil ha motivasjon for nettopp å kommunisere bedre eller legge til rette for mestringsopplevelser (Sawyerr, Strauss \& Yan, 2005). Motsatt vil en negativ holdning til den inkluderte arbeidstakeren føre til mangel på samme form for motivasjon.

Til sist vil en positiv holdning til gruppen den inkluderte arbeidstakeren representerer bidra til å styrke de helsefremmende effektene av arbeidsinkludering. Gitt positive holdninger hos ordinære arbeidstakere (og arbeidsgivere), vil det interpersonlige gruppeklimaet kunne styrkes, sammen med motivasjonen for å utbedre helserelaterte risikofaktorer. Motsatt vil negative holdninger til den inkluderte arbeidstaker kunne skape konflikt i det interpersonlige gruppeklimaet, og dermed vil motivasjonen til å utbedre risikofaktorer hos den inkluderte arbeidstakeren være mindre (Hartel, 2005).

Det er imidlertid viktig å understreke den gjensidige effekten som vil kunne oppstå i et slikt møte. Den ordinære arbeidstakers holdninger vil kunne bli utfordret i møte med en arbeidstaker som har en psykisk lidelse. Basert på sosial identitetsteori vet vi at nærheten til individer i ulike grupper er avgjørende for våre holdninger (Tajfel \& Turner, 1985). Det vil si at økt interaksjon med individer fra ulike grupper får oss til å anerkjenne kvalitetene hos enkeltindividet fremfor å se på individet som kun en del av en sosial gruppe (for eksempel «psykisk syke»). Oppsummert ser vi derfor at de ordinært ansattes holdninger til gruppen den inkluderte arbeidstaker er en del av, påvirker effekten av arbeidsinkludering på motivasjon, lederutvikling og arbeidsmiljø. Antakelse 6 blir derfor: 
a6: For at arbeidsinkludering skal ha positiv effekt, må arbeidstakere, arbeidsgruppen og lederen ha en positiv holdning til den sosiale gruppen den inkluderte arbeidstakeren er en del av.

\section{Forventninger}

Forventninger om suksess er også en modererende faktor som vil være avgjørende for om et arbeidsinkluderingsinitiativ vil påvirke enkeltindividet positivt. Teorien om planlagt atferd (Ajzen, 1991) og sosio-kognitiv teori (Bandura, 1997), understreker hvordan forventningene til suksess er avgjørende for både motivasjon og identifisering. Hvis ansatte, ledere og arbeidsgrupper tror de kan lykkes med å inkludere individer med nedsatt arbeidsevne eller tilretteleggingsbehov, er det også mer sannsynlig at inkluderingen vil ha en positiv effekt og videre bidra til motivasjon, lederutvikling og kollektiv mestring i arbeidsgruppen (Bandura, 1997). Hvis de ansatte, lederen eller arbeidsgruppen derimot er tvilende til om de kan mestre inkluderingen av en slik arbeidstaker, for eksempel på bakgrunn av tidligere negative erfaringer med inkluderingsinitiativ, manglende tro på egen kompetanse til å bidra, mangel på tid og ressurser eller manglende hjelp og oppfølging eller at arbeidsinkluderingen skjer mot de ansatte og mellomleders vilje, er sannsynligheten for at arbeidsinkludering skal ha en positiv spill-over effekt på motivasjon, lederutvikling og arbeidsmiljø, vesentlig lavere. Her vil i stedet negative effekter kunne oppstå i form av oppfattelsen om arbeidsinkludering som en ekstra byrde, og potensielt føre til en ekstra belastning og dermed risikere et økt konfliktnivå. Antakelse 7 blir derfor:

a7: For at arbeidsinkludering skal ha en positiv effekt må arbeidstakerne, lederen og arbeidsgruppen ha en forventning om suksess knyttet til arbeidsinkluderingen.

\section{Forutsetninger for modellen}

Det er viktig for oss å presisere at det overordnede perspektivet på positive effekter av arbeidsinkludering ikke er en selvfølge for organisasjoner 
som velger å implementere arbeidsinkludering som strategi. Dette diskuteres til dels gjennom de foregående antakelsene, hvor holdninger og forventninger til suksess defineres som avgjørende moderatorer. Likevel er det flere andre faktorer som må være til stede for at organisasjoner skal få ut potensialet som ligger i arbeidsinkludering. Dette illustreres best gjennom Herzbergs tofaktor-teori (Herzberg, Mausner \& Snyderman, 1959). Her skilles det mellom faktorer som skaper trivsel og faktorer hvor fraværet av disse skaper mistrivsel. Disse kalles henholdsvis motivasjonsfaktorer og hygienefaktorer. Et viktig aspekt ved Herzbergs teori er at hygienefaktorene må være tilfredsstillende før motivasjonsfaktorene kan ha effekt. Vi argumenterer derfor for at moderatorene vi har presentert - ansattes holdninger og forventning til suksess - i denne sammenheng bør ses på som motivasjonsfaktorer. Det er to hovedgrunner til argumentasjonen knyttet til dette. Først og fremst vil det være vanskelig å i det hele tatt generere positive holdninger eller forventning om suksess rundt et arbeidsinkluderingsinitiativ dersom den nåværende situasjonen i en organisasjon er preget av mistrivsel. Den andre hovedgrunnen er at effektene av arbeidsinkludering må ses i et mer langsiktig perspektiv. Økte krav om tilrettelegging og oppfølging er vanskelige å imøtekomme for en organisasjon dersom situasjonen tilsier at organisasjonen bør prioritere kortsiktige krisetiltak.

Ser vi på modellen vår vil vi argumentere for at samtlige av egenskapene representert av hvert hjørne - motivasjon, tilknytning, ledelse, arbeidsmiljø og motivasjon - må oppfylle et minimumskrav for at organisasjonen skal være i stand til å gjennomføre arbeidsinkluderingsinitiativer, og dermed utnytte effektene av arbeidsinkluderingen til fulle. Dersom en organisasjon for eksempel er preget av et dårlig arbeidsmiljø, vil de potensielle effektene av arbeidsinkludering være lavere enn ved et akseptabelt arbeidsmiljø.

Det er likevel viktig å presisere at arbeidsinkludering også kan bidra preventivt overfor fremtidige utfordringer gjennom de positive effektene som er skissert opp tidligere i kapitlet. Dette gir arbeidsinkluderingsinitiativer en mer proaktiv profil, og kan med andre ord gjøre organisasjoner mer robuste i møte med fremtidige utfordringer. 


\section{Begrensninger}

En overordnet kritikk av litteraturen som benyttes i kapitlet er at det kun er indirekte belysninger av sammenhengene som søkes etablert. Dette fordi det ikke ennå finnes empiri som direkte undersøker de sammenhengene det argumenteres for. I så måte blir ikke den direkte sammenhengen mellom for eksempel CSR og organisatorisk effekter etablert direkte, men studier som peker på hvordan CSR litteraturen kan bidra til å forstå de organisatoriske effektene av arbeidsinkludering blir fremhevet. Litteraturen som benyttes er heller ikke en uttømmende presentasjon av mulige sammenhenger som eksisterer mellom arbeidsinkludering og organisatoriske effekter. Sammenhengene som undersøkes i kapitlet er basert på rammeverket til Burke og Litwin (1992), og det vil derfor kunne være andre sammenhenger som ikke er innebefattet av dette rammeverket det vil kunne være relevant å undersøke.

Dette leder også til en begrensning ved den overordnede modellen som blir presentert, da det også vil kunne være andre og relevante komponenter i modellen. Fremtidige eksplorative studier vil kunne gi utfyllende kunnskap om nettopp dette.

\section{Praktiske implikasjoner}

Funnene i kapitlet har flere viktige praktiske implikasjoner, og illustrerer hvordan arbeidsinkludering kan være et viktig strategisk virkemiddel som skaper vinn-vinn effekter for både de ordinært ansatte så vel som arbeidstakeren og organisasjonen. Likevel presiserer vi gjennom vår modell at hygienefaktorer bør være ivaretatt på et akseptabelt nivå $f ø r$ man initierer arbeidsinkluderingstiltak. Vi argumenterer for at jobbsikkerhet og tilfredsstillende mellommenneskelige relasjoner blant kollegaer og leder/medarbeider er nødvendig for at man skal oppnå positive effekter av arbeidsinkludering. Dette skal ikke forstås som at organisasjoner som ansetter arbeidstakere med nedsatt arbeidsevne eller tilretteleggingsbehov må være perfekte organisasjoner, men snarere at de må ha noen grunnleggende faktorer på plass for å lykkes med inkluderingsinitiativene. 
For det andre peker kapitlet på viktigheten av hvilke holdninger de ordinært ansatte har til gruppen den inkluderte arbeidstakeren representerer. Det kan derfor være viktig å styrke positive holdninger og redusere eventuelle stereotypiske oppfatninger til gruppen gjennom

- $ø k t$ kunnskap om gruppen (eksempelvis kunnskap om psykisk sykdom)

- åpenhet fra den inkludertes side

- mulighet for samarbeid og nærhet til den inkluderte arbeidstaker

- mellomleder som god rollemodell

For det tredje peker kapitlet også på viktigheten av å skape en forventning om suksess for at arbeidsinkludering skal ha en positiv effekt. Dette kan man skape gjennom

- å sikre relevant oppfølging fra relevante instanser, for eksempel gjennom økonomisk og praktisk støtte til tilrettelegging eller tilgang til kompetent rådgiver NAV

- å sørge for å gi tid og ekstra ressurser for de som er praktisk involvert i arbeidsinkluderingen (mellomleder, nærmeste kollegaer)

- åpenhet og dialog, både fra medarbeidere, mellomleder og den inkludertes side

\section{Forslag til videre forskning}

Dette kapitlet er ment som et begynnende teoretisk rammeverk for å utforske de organisatoriske effektene av inkludering av personer med nedsatt arbeidsevne eller særlige tilretteleggingsbehov. Kvalitative studier som undersøker hvordan ledere og ansatte oppfatter at arbeidsinkludering påvirker ulike nivåer i organisasjonen vil være særlige relevante å undersøke. Samtidig vil det også være spennende å undersøke hvilken holdning ansatte har til de ulike gruppene som blir inkludert, og ikke minst hva som skaper disse holdningene. Det samme gjør seg gjeldende for forventning om suksess, og her vil det være relevant å undersøke hva som er avgjørende for om ansatte og ledere tror de kan lykkes med 
arbeidsinkludering. I kvantitative studier av sammenhengene som foreslås i studien, vil det være nyttig å se på sammenhengene mellom de ulike mediatorene og moderatorene i modell 1 for å kunne avgjøre den relative viktigheten av moderatorene det argumenteres for i kapitlet. Det vil være hensiktsmessig med longitudinelle kvantitative (og kvalitative) studier av modellen hvor man kan undersøke effekter på motivasjon, lederutvikling, arbeidsmiljø og organisatoriske prestasjoner over tid, samt hvordan holdninger og forventninger utvikler seg over en lengre tidsperiode.

\section{Konklusjon}

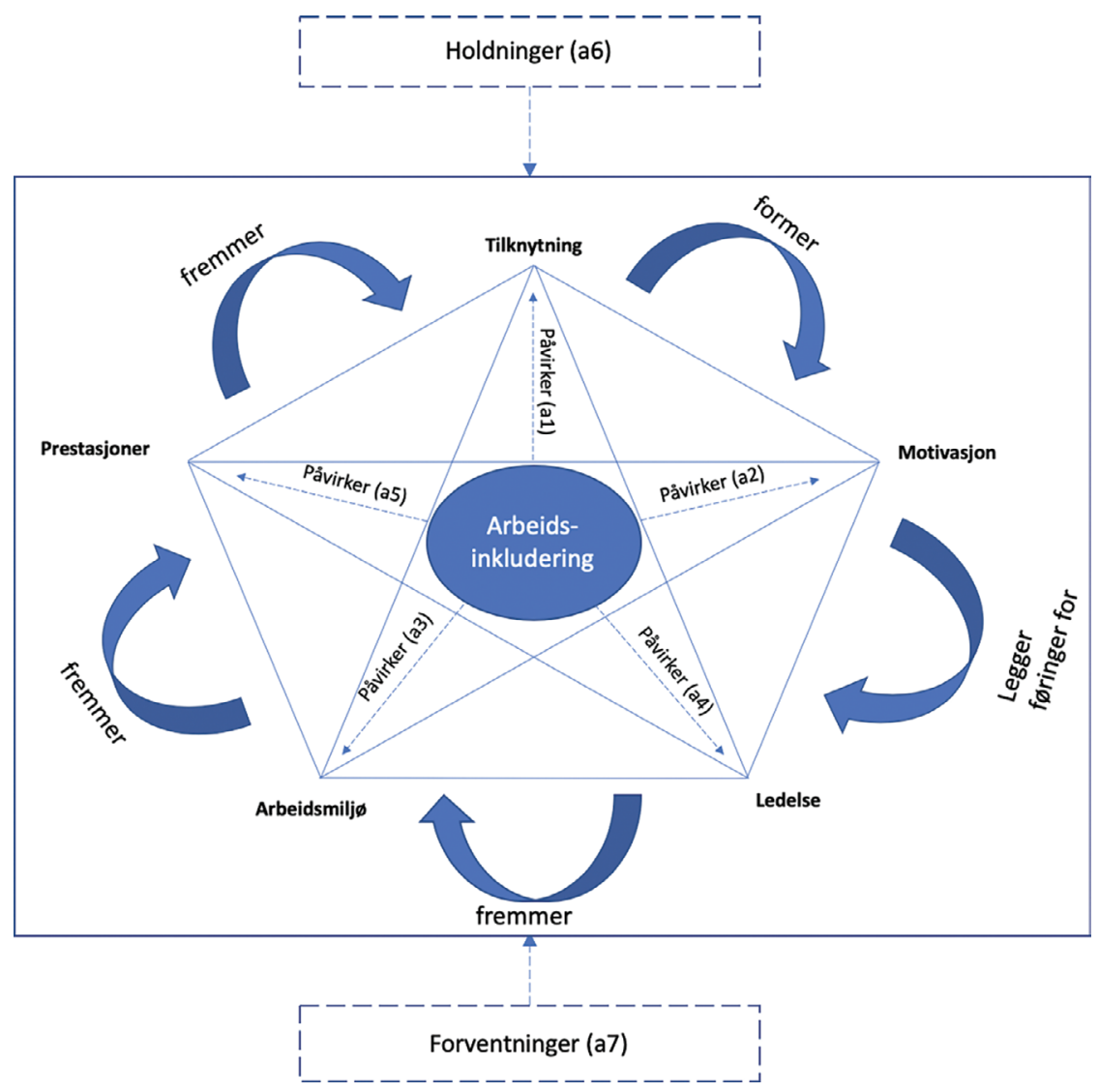

Modell 2. Inkluderingsdiamanten med tilhørende antakelser. 
I dette kapitlet har vi knyttet flere forskningsfelt sammen, og med bakgrunn i dette formulert en modell som illustrerer hvilke positive effekter arbeidsinkludering kan bidra med inn i organisasjoner, gitt de riktige forutsetningene. Som vi ser i modellen over har arbeidsinkludering potensiale til å øke ordinære ansattes tilknytning til organisasjonen (a1), $ø$ ke deres motivasjon (a2), utvikle ledere som er ansvarlige for arbeidsinkluderingsinitiativet (a3) og fremme et mer helsefremmende og inkluderende arbeidsmiljø (a4). Summen av disse vil øke organisasjonens prestasjoner totalt sett (a5). Gitt de riktige forutsetningene for oppstart av et arbeidsinkluderingsinitiativ, vil de ordinært ansattes holdninger til de som skal inkluderes (a6) og deres forventninger til suksess knyttet til arbeidsinkluderingsinitiativet (a7) moderere i hvor stor grad organisasjonene vil kunne oppnå positive effekter av arbeidsinkludering. Gjennom å peke på egenverdien arbeidsinkludering har for organisasjoners utvikling, kan disse funnene være en katalysator for økt arbeidsinkludering i det norske arbeidslivet. Arbeidsinkludering kan derfor være et viktig verktøy for et styrket nasjonalt arbeidsfellesskap, økt sosial bærekraft og bedre utnyttelse av menneskelige ressurser.

Gjennom modellen som presenteres har vi illustrert sammenhengen mellom ulike positive effekter arbeidsinkludering kan tilføre allerede eksisterende elementer i en organisasjon. Modellen representerer dermed et nytt perspektiv som kan generere ny innsikt i positive effekter ved arbeidsinkludering, og derfor også gi organisasjoner økt motivasjon for arbeidsinkludering som del av organisasjonsutviklingen. Modellen vektlegger også sammenhengene mellom de ulike elementene som kan påvirkes i positiv retning som følge av arbeidsinkludering. Modellen forteller oss imidlertid lite om hvordan disse effektene skal oppnås i praksis, da den kun illustrerer mulighetene knyttet til arbeidsinkludering. Derfor kan det tenkes at modellen gir et noe ensidig bilde på effektene av arbeidsinkludering, og at potensielle negative effekter ikke blir tatt høyde for, noe som kan gi modellen et naivistisk preg. Derfor understrekes det at modellen er ment som et teoretisk fundament for videre forskning på organisatoriske effekter av arbeidsinkludering, og at den vil revideres fortløpende etterhvert som det genereres mer empiriske data knyttet til vårt forskningsprosjekt på feltet. 
Kapitlet bidrar til både teori og praksis på området, tydeliggjort gjennom tre overordnede karakteristikker: For det første tar den et fundamentalt annerledes perspektiv på arbeidsinkludering. Tidligere forskning på arbeidsinkludering har tilnærmet utelukkende lagt vekt på hvilke faktorer som fremmer eller hemmer inkluderingen av individer med nedsatt arbeidsevne eller tilretteleggingsbehov, eller hvordan ulike demografiske variabler påvirker effektiviteten i arbeidsgruppen/organisasjonen. Dette kapitlet endrer dette fokuset ved å i stedet se på hvordan organisatoriske parametere påvirkes av arbeidsinkludering. I så måte flettes teori fra arbeidsinkludering, CSR, mangfoldslitteratur og organisasjonspsykologi sammen for å gi et felles grunnlag for videre forskning på effektene av arbeidsinkludering. For det andre har kapitlet betydning for praksis på området, da de teoretiske funnene i kapitlet kan bidra til å inspirere organisasjoner til arbeidsinkludering gjennom tydeliggjøring av mulige positive effekter dette kan ha for organisasjoner som helhet. For det tredje gir kapitlet et innblikk i faktorer som må være på plass for at organisasjoner skal kunne utnytte potensialet i arbeidsinkludering som den organisatoriske diamanten den faktisk er.

\section{Referanser}

Ajzen, I. (1991). The theory of planned behavior. Organizational behavior and human decision processes, 50(2), 179-211. https://doi.org/10.1016/0749-5978(91)90020-T

Anvik, C. H. \& Gustavsen, A. (2012). Ikke slipp meg! Unge, psykiske helseproblemer, utdanning og arbeid (NF-rapport 13). Hentet fra http://www.nordlandsforskning.no/ getfile.php/132436-1412587259/Dokumenter/Rapporter/2012/Rapport_13_2012.pdf

Antonakis, J. E., Cianciolo, A. T. \& Sternberg, R. J. (2004). The nature of leadership. London: Sage.

Aronsson, G. \& Lindh, T. (2004). Långtidsfriskas arbetsvillkor: En populationsstudie (Arbete och Hälsa 2004:10). Arbetslivinstitutet. Hentet fra http://hdl.handle. net/2077/4332

Ashforth, B. E. \& Mael, F. (2004). Social identity theory and the organization. I M. Hatch \& M. Schultz (Red.), Organizational identity: A reader (s. 134-16o). Oxford: Oxford University Press.

Aguinis, H. \& Glavas, A. (2019). On corporate social responsibility, sensemaking, and the search for meaningfulness through work. Journal of Management, 45(3), 1057-1086. https://doi.org/10.1177/0149206317691575 
Bandura, A. (1997). Self-efficacy: The exercise of control. New York: Worth Publishers. Bass, B. M. (1985). Leadership and performance beyond expectations. New York: Free Press.

Bergsteiner, H. \& Avery, G. C. (2010). A theoretical responsibility and accountability framework for CSR and global responsibility. Journal of Global Responsibility, 1(1), 8-33. https://doi.org/10.1108/20412561011038529

Burke, W. W. \& Litwin, G. H. (1992). A causal model of organizational performance and change. Journal of management, 18(3), 523-545. https://doi. org/10.1177/014920639201800306

Day, D. V., \& Thornton, A. M. A. (2017). Leadership development. I J. Antonakis \& D. V. Day (Red.), The nature of leadership (3. utg., s. 354-381). California: SAGE Publications.

Deci, E. L. \& Ryan, R. M. (1985). The general causality orientations scale: Selfdetermination in personality. Journal of research in personality, 19(2), 109-134. https://doi.org/10.1016/0092-6566(85)90023-6

Deci, E. L. \& Ryan, R. M. (2002). Overview of self-determination theory: An organismic dialectical perspective. I E. L. Deci \& R. M. Ryan (Red.), Handbook of self-determination research (s. 3-33). Rochester: University of Rochester Press.

DeJoy, D. M., Wilson, M. G. (2003). Organizational health promotion: Broadening the horizon of workplace health promotion. American Journal of Health Promotion, 17(5), 337-341. https://doi.org/10.4278/0890-1171-17.5.337

Downey, S. N., Werff, L. V. D., Thomas, K. M. \& Plaut, V. C. (2015). The role of diversity practices and inclusion in promoting trust and employee engagement. Journal of Applied Social Psychology, 45(1), 35-44. https://doi.org/10.1111/jasp.12273

Eagly, A. H. \& Chaiken, S. (1993). The psychology of attitudes. California: Harcourt Brace College Publishers.

El Akremi, A., Gond, J. P., Swaen, V., De Roeck, K. \& Igalens, J. (2018). How do employees perceive corporate responsibility? Development and validation of a multidimensional corporate stakeholder responsibility scale. Journal of Management, 44(2), 619-657. https://doi.org/10.1177/0149206315569311

Falkum, E., Schaft, A. \& Spjelkavik., Ø. (2014). Arbeidsgivernes rolle i inkluderingen. I K. Frøyland \& Ø. Spjelkavik (Red.), Inkluderingskompetanse - ordinoert arbeid som mål og virkemiddel (s. 141-154). Oslo: Gyldendal Akademisk.

Frøyland, K. \& Spjelkavik, Ø. (2014). Inkluderingskompetanse - et integrert perspektiv. I K. Frøyland \& Ø. Spjelkavik (Red.), Inkluderingskompetanse ordincert arbeid som mål og virkemiddel (s. 18-32). Oslo: Gyldendal Akademisk.

Govier, T. (1999). What is acknowledgement and why is it important? (Konferansebidrag OSSA 3). Hentet fra http://scholar.uwindsor.ca/ossaarchive/

Hanson, A. (2007). Work place health pomotion: A salutogenic approach. Bloomington: AuthorHouse. 
Hernes, T., Heum, I. \& Haavorsen, P. (2010). Arbeidsinkludering. Om det nye politikk-og praksisfeltet i velferds-Norge. Oslo: Gyldendal Akademisk.

Herzberg, F. I., Mausner, B. \& Snyderman, B. (1959). The motivation to work (2. utg.). New York: John Wiley.

Jayne, M. E. A. \& Dipboye, R. L. (2004). Leveraging diversity to improve business performance: Research findings and recommendations for organizations. Human Resource Management, 43(4), 409-424. https://doi.org/10.1002/hrm.20033

Kim, C. H. \& Scullion, H. (2013). The effect of corporate social responsibility (CSR) on employee motivation: A cross-national study. Economics and Business Review, 13(2), 5-30. Hentet fra http://www.ebr.edu.pl/volume13/issue2/2013_2_5.pdf

Kossek, E. E. \& Zonia, S. C. (1993). Assessing diversity climate: A field study of reactions to employer efforts to promote diversity. Journal of Organizational Behavior, 14(1), 61-81. https://doi.org/10.1002/job.4030140107

Kulkarni, M., Boehm, S. A. \& Basu, S. (2016). Workplace inclusion of persons with a disability: Comparison of Indian and German multinationals. Equality, Diversity and Inclusion: An International Journal, 35(7/8), 397-414. https://doi.org/10.1108/ EDI-o8-2016-0066

Kuvaas, B., Buch, R., Weibel, A., Dysvik, A. \& Nerstad, C. G. (2017). Do intrinsic andextrinsic motivation relate differently to employee outcomes? Journal of EconomicPsychology, 61, 244-258. https://doi.org/10.1016/j.joep.2017.05.004

Lowe, G. S., Schellenberg, G. \& Shannon, H. S. (2003). Correlates of employees' perceptions of a healthy work environment. American Journal of Health Promotion, 17(6), 390-399. https://doi.org/10.4278/o890-1171-17.6.390

Maharaj, I. \& Schlechter, A. F. (2007). Meaning in life and meaning of work: Relationships with organisational citizenship behaviour, commitment and job satisfaction. Management Dynamics: Journal of the Southern African Institute for Management Scientists, 16(3), 24-41. Hentet fra https://hdl.handle.net/10520/ EJC69726

McCauley, C. D. \& Van Velsor, E. (Red.). (2003). The center for creative leadership handbook of leadership development (2. utg.). New York: John Wiley.

McClelland, D. C. \& Johnson, E. W. (1984). Learning to achieve. Glenview, IL: Scott Foresman \& Co.

Mowday, R. T., Porter, L. W. \& Steers, R. (1982). Organizational linkages: The psychology of commitment, absenteeism, and turnover. New York: Academic Press.

Mumford, T. V., Campion, M. A. \& Morgeson, F. P. (2007). The leadership skills strataplex: Leadership skill requirements across organizational levels. The Leadership Quarterly, 18(2), 154-166. https://doi.org/10.1016/j.leaqua.2007.01.005

NAV. (2020). Personer med nedsatt arbeidsevne. Hentet fra https://www.nav.no/no/ nav-og-samfunn/statistikk/aap-nedsatt-arbeidsevne-og-uforetrygd-statistikk/ nedsatt-arbeidsevne. 
Norvoll, R. (2011). Jeg vil ikke stå utenfor: Arbeid og utdanning sett med brukernes øyne. AFI-notat 10/2011. Arbeidsforskningsinstituttet.

Joseph, O. B. (2014). Effectiveness of performance appraisal as a tool to measure employee productivity in organisations. Journal of Public Administration and Governance, 4(4, 135-148. https://doi.org/10.5296/jpag.v4i4.6912

Pugh, S. D., Dietz, J., Brief, A. P. \& Wiley, J. W. (2008). Looking inside and out: The impact of employee and community demographic composition on organizational diversity climate. Journal of applied psychology, 93(6), 1422-1428. https://doi.org/ 10.1037/aoo12696

Ramvi, E. \& Farstad, L. (2011). Arbeid og psykisk helse: en kvalitativ studie av lederes erfaringer med å ha unge med psykisk lidelse i arbeidspraksis (Rapport nr. 30, Universitetet i Stavanger). Hentet fra http://hdl.handle.net/11250/226820

Ramvi, A. E., Skarpaas, L. S. \& Løvereide, L. (2013). Veien inn i arbeidslivet. Lederes erfaring med inkludering av unge voksne med psykiske helseplager (Rapport nr. 40, Universitetet i Stavanger). Hentet fra https://evalueringsportalen.no/

Rupp, D. E., Ganapathi, J., Aguilera, R. V. \& Williams, C. A. (2006). Employee reactions to corporate social responsibility: An organizational justice framework. Journal of Organizational Behavior, 27(4), 537-543. https://doi.org/10.1002/job.38o

Rusch, F. R. (1990). Supported employment: Models, methods, and issues. Sycamore, IL: Sycamore Publishing.

Sawyerr, O. O., Strauss, J. \& Yan, J. (2005). Individual value structure and diversity attitudes: The moderating effects of age, gender, race, and religiosity. Journal of Managerial Psychology, 2o(6), 498-521. https://doi.org/10.1108/02683940510615442

Shamir, B., House, R. J. \& Arthur, M. B. (1993). The motivational effects of charismatic leadership: A self-concept based theory. Organization Science, 4(4), 577-594. https://doi.org/10.1287/orsc.4.4.577

Spjelkavik, Ø., Hagen, B. \& Härkäpää, K. (2011). Supported employment i Norden (AFI-rapport 3/2011). Hentet fra http://hdl.handle.net/20.500.12199/3993

Spjelkavik, Ø., \& Thingbø-Støldal, B. (2014). Jobbmatch og jobbutvikling. Frøyland, K. \& Spjelkavik, Ø. (Red.), Inkluderingskompetanse - ordincert arbeid som mål og virkemiddel (51-65). Oslo: Gyldendal Akademisk.

Statistisk sentralbyrå. (2019a). Persons with disabilities. Labour force survey. Hentet fra https://www.ssb.no/en/arbeid-og-lonn/statistikker/akutu

Statistisk sentralbyrå. (2019b). Employment among immigrants, register-based. Hentet fra https://www.ssb.no/en/arbeid-og-lonn/statistikker/innvregsys

Tajfel, H. \& Turner, J. C. (1985) The social identity theory of intergroup behavior. I S. Worchel \& W. G. Austin (Red.), Psychology of intergroup relations (2. utg., s. 7-24). Chicago: Nelson-Hall.

Williams, L. J., Anderson, S. E. (1991). Job satisfaction and organizational commitment as predictors of organizational citizenship and in-role 
behaviors. Journal of Management, 17(3), 601-617. https://doi.org/10.1177/ 014920639101700305

Wrzesniewski, A., LoBuglio, N., Dutton, J. E. \& Berg, J. M. (2013). Job crafting and cultivating positive meaning and identity in work. I A. B. Bakker (Red.), Advances in positive organizational psychology (Bd. 1, s. 281-302). Bingley: Emerald Group Publishing.

Yukl, G. (2008). How leaders influence organizational effectiveness. The Leadership Quarterly, 19(6), 708-722. https://doi.org/10.1016/j.leaqua.2008.09.008

Yukl, G. \& Mahsud, R. (2010). Why flexible and adaptive leadership is essential. Consulting Psychology Journal: Practice and Research, 62(2), 81-93. https://doi. org/10.1037/aoo19835 


\title{
Hvordan påvirker tillit og psykologisk trygghet implementering av radikale endringer? En casestudie av digital tjenesteteknologi
}

\author{
Birthe Kåfjord Lange \\ Hoyskolen Kristiania \\ Anne Haugen Gausdal \\ Hoyskolen Kristiania
}

\begin{abstract}
Studies of radical change pay more attention to early phases of the change processes than to later phases and implementation. Research that can contribute to a deeper understanding of factors that influence the implementation of such changes is therefore called for. The purpose of this chapter is to increase the insight and understanding of how trust and psychological safety impact implementation of radical changes. To meet this purpose, we raise the following research questions: 1) What are the differences and similarities between the concepts of trust and psychological safety? 2) How does trust and psychological safety influence implementation of radical changes in organizations? To answer the first question, we start by conducting a review of the literature on trust and psychological safety in part one. Although both concepts are widely used, the observable level of precision and understanding of the concepts varies. Our review reveals that the concepts are popular and quite closely related, yet there are also important differences worth noticing. To answer the second research question, we apply the insight from part one to discuss a conceptual case, well-known to many organizations in current business life; the implementation of radical new service technology. The discussion reveals that both trust and psychological safety play important, but somewhat different roles in top-down and bottom-up organized radical and adaptive change processes respectively.
\end{abstract}

Keywords: trust, psychological safety, radical changes, adaptive changes, implementation 


\section{Introduksjon}

Forskning som kan bidra til dypere forståelse av faktorer som påvirker implementering av radikale endringer er etterlyst (Huy, Corley \& Kraatz, 2014). A ta i bruk eller implementere radikale endringer innebærer usikkerhet og risiko. For eksempel risiko for at endringene ikke virker som de skal, risiko for at du selv, andre ansatte og/eller kunder ikke klarer å lære seg eller bruke dem riktig, eller at arbeidsplasser, arbeidsoppgaver og/eller kunder blir borte. Det innebærer også usikkerhet på flere områder, blant annet hvordan det påvirker organisering, arbeidsoppgaver og samhandling mellom ansatte, og mellom ansatte og kunder og leverandører. Tillit er en mekanisme som erstatter det vi ikke kan eller ønsker å overvåke eller kontrollere, enten fordi det ikke er mulig, for eksempel å «lese» andres tanker, eller fordi det ikke er ønskelig, for eksempel fordi det er for ressurskrevende. For å håndtere usikkerhet og risiko er tillit og psykologisk trygghet sentralt. I dette kapitlet vil vi derfor utforske og drøfte betydningen av tillit og psykologisk trygghet i forbindelse med implementering av radikale endringer.

Tillit og psykologisk trygghet er beslektede, men ikke synonyme begreper. Tillit defineres som «the willingness of a party to be vulnerable to the actions of another party based on the expectation that the other will perform a particular action important to the trustor, irrespective of the ability to monitor or control that other party» (Mayer, Davis \& Schoorman, 1995, s. 712). Denne villigheten til å være sårbar innebærer at en form for risiko og usikkerhet. Tillit er derfor en viktig mekanisme i læringsfremmende aktiviteter som deling av kunnskap, spesielt taus kunnskap (Polanyi, 1983), som er viktig for å skape ny kunnskap (Nonaka, Toyama \& Konno, 200o). Psykologisk trygghet handler om opplevelsen av hvorvidt det føles trygt å ta risiko i mellommenneskelige forhold (Edmondson, 1999). Følelsen av psykologisk trygghet kommer fra gjensidig tillit og respekt for hverandre, hvor man ikke frykter for å bli utsatt for negative konsekvenser relatert til eget selvbilde, status eller karriere (Kahn, 1990). Høy psykologisk trygghet har vist seg å være positivt for læringsatferd i organisasjoner, ved at det føles lettere å spørre om tilbakemelding, dele informasjon, spørre om hjelp, snakke om feil eller eksperimentere (Edmondson, 1999). Graden av opplevd psykologisk trygghet er derfor 258 
relevant for å forstå implementering av radikale endringer. I hvilken grad tør man vise at man ikke kan eller ikke forstår de nye mulighetene man er forventet å ta stilling til, eller begynne å bruke, uten å frykte redusert respekt, status eller posisjon?

Både tillit og psykologisk trygghet inneholder elementer av usikkerhet og opplevd risiko. En sentral konseptuell forskjell mellom begrepene er imidlertid at tillit legger vekt på hvordan en person oppfatter en eller flere personer, mens psykologisk trygghet legger vekt på hvordan medlemmer av en gruppe eller et team oppfatter en felles gruppenorm (Frazier, Fainschmidt, Klinger, Pezeshkan \& Vracheva, 2017). Det er imidlertid behov for bedre innsikt i flere sammenhenger, forskjeller og likheter mellom tillit og psykologisk trygghet (Vaida, 2019), samt hvordan tillit og psykologisk trygghet påvirker implementering av radikale endringer.

Vi vil gjennom dette kapitlet besvare følgende forskningsspørsmål:

1. Hva er forskjellene og likhetene mellom begrepene tillit og psykologisk trygghet?

2. Hvordan påvirker tillit og psykologisk trygghet implementering av radikale endringer i organisasjoner?

For å svare på disse spørsmålene starter vi med en litteraturgjennomgang av sentrale forskningsbidrag om tillit og psykologisk trygghet. Begge begrepene er populære og mye brukt, men ofte med en noe upresis forståelse av hva de inneholder og hva som skiller dem fra hverandre. Først presenteres og drøftes hvert av begrepene mer inngående, før viktige likheter og forskjeller mellom dem diskuteres for å besvare det første forskningsspørsmålet. En stadig større andel av verdiskapningen i Norge kommer fra produksjon av tjenester: i 2018 kom 78 prosent av Norges bruttonasjonalprodukt fra tjenesteproduksjon, og andelen er forventet å vokse til 90 prosent innen 2060 (Andreassen \& Kristensen, 2019). Digitalisering gir store muligheter for helt nye og til dels ukjente og innovative måter å produsere og levere tjenester på (Daazenko \& Grønquist, 2016), og bidrar i stadig større grad til ny tjenesteutvikling for å øke effektiviteten eller forbedre kvaliteten på tjenestene (Randhawa \& Scerri, 2015). 
Selv om fremveksten av ulike former for digital tjenesteteknologi muliggjør kvalitet- og/eller effektivitetsforbedringer er ikke teknologien i seg selv nok; digitale løsninger må implementeres på en god måte (Andersen \& Sannes, 2017; Bygstad \& Iden, 2017). Vi bruker derfor implementering av radikalt ny tjenesteteknologi som en konseptuell building block-case (George \& Bennett, 2005) i denne studien, og bruker resultatet av litteraturgjennomgangen til å drøfte casen og besvare det andre forskningsspørsmålet. Gjennom å bruke en konseptuell case får vi belyst fenomenet og utforsket mønstre på et generelt nivå som vi mener gir nyttig og nødvendig innsikt til eventuelle fremtidige empiriske studier. Avslutningsvis påpeker vi teoretiske og praktiske implikasjoner av studien.

\section{Tillit og psykologisk trygghet}

Tillit er et flernivå- (Fulmer \& Gelfand, 2012) og flerdimensjonalt begrep (Gillespie, 2003). Det er et flernivåbegrep fordi det eksisterer mellom individer, grupper, organisasjoner og nasjoner, men også på tvers av disse nivåene: en person kan for eksempel ha tillit til en organisasjon, som Høyskolen Kristiania eller Cappelen Damm. Den som har tillit er alltid en person, gruppe eller organisasjon, men den eller det man har tillit til, kan være «ansiktsløs/t». Dette kan være institusjonell tillit, for eksempel tillit til politiet eller domstolene, eller tillit til en tittel, for eksempel tillit til lærere, bussjåfører eller leger. Det kan også være tillit til et varemerke, for eksempel Apple eller Mercedes-Benz, eller tillit til en teknologi, for eksempel en sykkel eller PC, eller til programvare og teknologiske løsninger (Hoff \& Bashir, 2014; Carlan, Coppens, Sys, Vanelslander \& VanGaste, 2019), for eksempel nettbank, bitcoin eller autonome fly.

Tillit er også et flerdimensjonalt begrep fordi tilliten til en og samme aktør eller teknologi, for eksempel en person, kan variere ut fra hva vi har tillit til. Vi kan for eksempel ha tillit til hvordan en person utfører en arbeidsoppgave på jobben, mens vi ikke ønsker å sette oss inn i vedkommendes bil eller la vedkommende passe barnet vårt. Dette kan forklares med at i hvilken grad vi opplever en annen aktør (person, gruppe, organisasjon eller annet) som tillitsverdig, kan være basert på for eksempel hvordan vi oppfatter aktørens evner, benevolens eller integritet (Mayer 
et al., 1995). Evner, benevolens og integrititet blir derfor sett på som tre dimensjoner av tillitsverdighet. Evner, eller ability, definers som «the group of skills, competencies and characteristics that enable a party to have influence within some specific domain» (Mayer et al., 1995, s. 717). Benevolence kan oversettes med «velvilje», og defineres av Mayer et al. (1995, s. 718) som «the extent to which a trustee is believed to want to do good to the trustor, aside from an egoistic profit motive». En benevolent person er en som ikke bare er opptatt av sine egne interesser, men som er i stand til å koble interessene med en intensjon om å bidra for andre og som ønsker andre godt. Benevolens eller velvilje har derfor aspekter av altruisme i seg (Mayer et al., 1995, s. 719-720). Integritet definers som «the trustor's perception that the trustee adheres to a set of principles that the trustor finds acceptable» sammen med «the consistency of the party's past actions, credible communications about the trustee from other parties, belief that the trustee has a strong sense of justice, and the extent to which the party's actions are congruent with his or her words» (Mayer et al., 1995, s. 719-20). Integritet innebærer derfor at den eller det man har tillit til holder det som loves og har akseptabel rettferdighetssans, og handler mye om moral og ærlighet (McFall, 1987).

Det er imidlertid et spørsmål om hvorvidt de ulike dimensjonene av tillit også gjelder for ansiktsløs tillit. Organisasjoner, titler, teknologi og teknologiske løsninger kan definitivt ha evne til å utføre noe. Dimensjonen evner er derfor relevant. Benevolens eller velvilje er derimot koblet til menneskelige holdninger, og dette en derfor en dimensjon av tillit som ikke ser ut til å gjelde for ansiktsløs tillit. Når det gjelder integritet kan kanskje organisasjoner, men ikke titler, teknologi og teknologiske løsninger, ha moral eller rettferdighetssans i psykologisk forstand. De kan ha, eller oppfattes å ha, holdninger, ved at for eksempel programvare eller algoritmer diskriminerer grupper av mennesker, for eksempel på grunn av rase, hudfarge, alder eller kjønn, eller har løsninger som man ikke alltid kan stole på at virker slik de skal: penger i nettbanken kan eksempelvis havne på feil konto, eller autonome flysystemer kan styrte flyet samtidig som pilotenes mulighet til å overstyre systemet er satt ut av spill. Vi påstår derfor at ansiktsløs tillit kan ha dimensjoner av evner og integritet, men ikke av benevolens eller velvilje. 
Amy Edmondson (2004) beskriver forskjellen mellom tillit og psykologisk trygghet på følgende måte: tillit handler om en persons vilje til å være sårbar overfor en annen, og velge å la eventuell tvil komme den andre til gode. Psykologisk trygghet handler derimot om i hvilken grad man tror at de andre vil la tvilen komme deg til gode, hvis du tar sjansen på å si hva du mener eller komme med innspill (Frazier et al., 2017). Ifølge Kahn (1990) vil forhold preget av høy tillit bidra til høyere grad av psykologisk trygghet. Tillit er med andre ord en (av flere) antecedents for psykologisk trygghet; graden av tillit påvirker graden av psykologisk trygghet.

Vi påstår imidlertid at psykologisk trygghet i mindre grad omhandler evner og ferdigheter (ability), som er en av dimensjonene i grunnlaget for tillit. Det å tro at andre lar tvilen komme deg til gode, som er det sentrale i psykologisk trygghet, ligger imidlertid relativt nærme velvilje og det å ønske å bidra for andre. Graden av psykologisk trygghet innebærer også en forventning om hva man tror de andre vil gjøre, det vil si i hvilken grad de vil la tvilen komme deg til gode, noe som inneholder elementer av integritet. Dette viser at ulike dimensjoner i grunnlaget for tillit er noe bredere enn det er for psykologisk trygghet, og at velvilje og til dels integritet ser ut til å være de dimensjonene av tillit som ligger nærmest å være antecedents for psykologisk trygghet.

Tillit er allerede definert som et flernivåbegrep. Det er imidlertid ikke like klart om psykologisk trygghet kan beskrives som det samme. I en omfattende reviewartikkel fra 2017 oppsummerer Newman, Donohue og Eva (2017, s. 522):

while there have been studies conducted at different levels of analysis, it is also the case that there has been a paucity of cross-level and multilevel psychological safety research. [...] more multi-level and cross-level work is needed to understand the relative influence of individual, team and organizational-level antecedents on psychological safety.

Selv om det både finnes og etterlyses flere studier av psykologisk trygghet på flere nivåer (individ, gruppe og organisasjon), handler kjernen i selve begrepet om mellommenneskelige relasjoner, gruppenormer og tro/ holdninger til andre mennesker (i hvilken grad man tror at de andre vil 
la tvilen komme deg til gode). Psykologisk trygghet ser derfor ut til å være et begrep som kun egner seg i mellommenneskelige sammenhenger, og ikke i ansiktsløse kontekster som går på forhold til institusjoner, titler og teknologiske løsninger.

Hittil har forskningen på psykologisk trygghet foregått mest på gruppenivå (Newman et al., 2017). Basert på definisjonen kan imidlertid psykologisk trygghet også brukes på individ- og organisasjonsnivå, slik som tillit. Vi konkluderer derfor med at både tillit og psykologisk trygghet kan være flernivåbegreper, og at dette er det forsket en del på innenfor tillit (se f.eks. Li, 2011), men mindre innenfor psykologisk trygghet (Newman et al., 2017; Roussin, McLean \& Rudolph, 2016). Siden begge begrepene omfatter elementer av velvilje og integritet, tillater vi oss å påstå at begge også er flerdimensjonale begreper. Tillit har imidlertid en bredere flerdimensjonalitet, som det er forsket relativt mye på (se f.eks. Svare, Gausdal \& Möllering, 2019), mens det etter vår kunnskap ikke i samme omfang er forsket på flerdimensjonaliteten av psykologisk trygghet.

\section{Hvordan påvirker tillit og psykologisk trygghet implementering av av radikale endringer i organisasjoner?}

For å kunne besvare dette spørsmålet, definerer vi først hva vi mener med radikale endringer. Deretter diskuterer vi sammenhengen mellom psykologisk trygghet og tillit på den ene siden og radikale endringer på den andre. I lys av dette kobler vi inn teori om casen, som er radikalt ny tjenesteteknologi. Til slutt drøfter vi hvordan tillit og psykologisk trygghet påvirker implementering av ny tjenesteteknologi.

\section{Hva betyr radikale endringer?}

Radikal endring defineres som «a rapid and simultaneous, discontinuous shift in the firm's strategic orientation, such as its products, markets, and ways of competing, and in its associated organizational activities» (Tushman \& Romanelli, 1985, sitert i Jarzabkowski, Lê \& Balogun, 2019). March (1991) introduserte et skille mellom det han kalte exploration 
(utforskning) og exploitation (utnytting). Mens utnytting handler om kontinuerlig skrittvis forbedring og utvikling, krever utforskning at organisasjoner evner å tenke helt nytt og utenfor de tradisjonelle rammene de tidligere har holdt seg innenfor. Det vil med andre ord si at å ta i bruk den nye teknologien oppleves som et brudd med tidligere etablert praksis, og dermed som noe radikalt nytt. Selv om det fremheves som viktig at organisasjoner finner en god balanse mellom inkrementelle endringer (utnytting) og radikale endringer (utforskning) (Levinthal \& March, 1993), er særlig organisasjoners manglende evne til å håndtere radikal omstilling til ny teknologi fremhevet som forklaring på hvorfor mange organisasjoner strever med å overleve over tid (O’Reilly III \& Tushman, 2013; Tushman \& O’Reilly III, 1996).

\section{Psykologisk trygghet og radikale endringer}

På samme måte som en person vil oppleve ulike grader av tillit i ulike situasjoner, vil også graden av psykologisk trygghet variere mellom ulike kontekster, situasjoner og tidspunkter. Psykologisk trygghet er med andre ord ikke et stabilt personlighetstrekk, men en tilstand som kan variere fra høy til lav for samme person i ulike settinger til ulike tidspunkt (Zhang, Fang, Wei \& Chen, 2010). For å forstå betydningen av tillit og psykologisk trygghet for leders håndtering av implementering av radikalt ny tjenesteteknologi, må vi derfor gjøre oss kjent med studier tar utgangspunkt i denne typen situasjoner hvor ledere møter nye ukjente muligheter.

Det er veldokumentert at psykologisk trygghet har stor betydning for organisasjoners åpenhet for endring og evne til å lære og utforske nye muligheter (Carmeli, Brueller \& Dutton, 2009; Edmondson, Bohmer \& Pisano, 2001; Frazier et al., 2017). I møtet med nye teknologiske muligheter eller digitalisering er organisasjoners og personers evne til å lære og tilegne seg nye rutiner og ny kompetanse sentral. En omfattende litteraturgjennomgang av Newman et al. (2017) viser at psykologisk trygghet påvirker læring i bred forstand (bl.a. via økt kreativitet, innovasjonsevne og kunnskapsdeling) både på individuelt nivå og på gruppe-/teamnivå. Et konkret eksempel er presentert av Edmondson et al. (2001) i en studie av 
hvordan psykologisk trygghet påvirker implementering av ny teknologi i et høyspesialisert fagmiljø ved et sykehus. For å lykkes med å innføre ny teknologi og digitalisere prosesser som krever nye kollektive rutiner, må organisasjonen gjennom en kollektiv læringsprosess. Denne prosessen påvirkes for det første av lederes atferd direkte: Hvordan lederne presenterer (frame) den nye teknologien, påvirker hvordan utfordringen med å lære seg det nye oppleves (fra spennende og interessant til truende og vanskelig). For det andre påvirkes den kollektive læringsprosessen også av graden av psykologisk trygghet: I team med lav psykologisk trygghet er teammedlemmer mindre villige til å risikere negative reaksjoner og mistillit fra andre i teamet. De holder dermed tilbake, og bidrar i mindre grad til å utforske nye muligheter eller gi feedback på andres forslag. Lav psykologisk trygghet reduserer med andre ord graden av kollektiv læring, som igjen reduserer utviklingen av nye kollektive rutiner som er nødvendige for å ta i bruk den nye teknologien.

Et annet konkret eksempel finner vi hos Zhang et al. (2010), som har studert hvordan psykologisk trygghet påvirker kunnskapsdeling i virtuelle samfunn. Deltakelse i virtuelle samfunn og team er en ny, digitalisert måte å samhandle på. For at virtuelle samfunn skal fungere som positive og effektive arenaer for samhandling, er man avhengig av at deltakerne aktivt bidrar og deler av sin kunnskap inn i det digitale fellesskapet. Deltakerne møtes ikke ansikt til ansikt, men forholder seg til hverandre via digitaliserte plattformer. Det kan skape større avstand mellom deltakerne, og gjøre psykologisk trygghet mindre relevant. Psykologisk trygghet viste seg imidlertid å ha signifikant betydning for i hvilken grad deltakerne i det virtuelle samfunnet hadde intensjon om å dele kunnskap i fellesskapet (Zhang et al., 2010). Psykologisk trygghet påvirker med andre ord ikke bare hvordan mennesker samarbeider og hvilke læringseffekter som oppstår i fysiske team eller arbeidsplasser, men også hvilke effekter man finner ved overgang til digitale samarbeid som i virtuelle samfunn/team. Virtuelle samfunn medfører i tillegg at mennesker i mindre grad enn før møtes også digitalt, for eksempel er møter med fordeling og koordinering av arbeidsoppgaver eller rapportering av resultater erstattet av teknologi, gjerne i form av en app. Dette gjør at mer kommunikasjon blir ansiktsløs. 


\section{Tillit og radikale endringer}

Forskning viser at kunnskapsdeling er den viktigste driveren for innovasjon (Jensen, Johnson, Lorenz \& Lundvall, 2007; Tödtling, Asheim \& Boschma, 2013). Tillit bidrar til kunnskapsdeling (Maurer, 2010; Miles, Miles \& Snow, 2005) og fremmer høyere kvalitet på denne, inkludert deling og absorbering av taus kunnskap, noe som medfører at kunnskapen som deles lettere kan generaliseres og brukes på nye områder (von Krogh, Ichijo \& Nonaka, 200o). Tillit er en viktig faktor for radikale endringer eller innovasjon. På grunn av risiko og usikkerhet knyttet til å skape og implementere nye ideer er tillit viktig for innovasjon på både organisasjons- og gruppenivå (Shazi, Gillespie \& Steen, 2015). Risiko og usikkerhet er her bl.a. knyttet til opportunistisk atferd, svikt i teknologi, uforutsette organisasjonshinder og økonomiske bekymringer. Tillit bidrar til at aktører deler informasjon og kollektivt løser problemer for å håndtere disse risikoene (Shazi et al., 2015). Shazi et al. (2015) fant i sin studie av utviklingsteam at de ulike dimensjonene av tillit hadde forskjellige funksjoner i ulike faser av teamets arbeid. I relasjonsbyggingsfasen var evne viktigst. Senere oppstod risiko for å avsløre, diskutere og foredle ideer, som er viktig for innovasjon og implementering. Dette kan medføre ideutvikling av lav kvalitet, tyveri av ideer eller at ideer blir latterliggjort. Siden velvilje fremmer kunnskapsdeling og reduserer risikoen for å bli latterliggjort, ble den identifisert som den viktigste tillitsdimensjonen for utvikling og implementering av nye løsninger (Shazi et al., 2015). Tillit basert på velvilje er forbundet med et ønske om å bidra for andre. Det kan innebære å dele informasjon når andre trenger det, for eksempel ansatte som deler informasjon med hverandre og med sin leder. Tillit basert på velvilje motvirker også risiko for opportunistisk misbruk av den delte informasjonen (Svare et al., 2020).

\section{Case: implementering av radikalt ny tjenesteteknologi}

Casen i denne studien er radikalt ny tjenesteteknologi. Hva er spesielt med tjenester, og hva er det ved implementering av ny tjenesteteknologi 
som gjør tillit og psykologisk trygghet særlig relevant, og derfor dette til et hensiktmessig case? For det første skiller tjenester seg fra produkter ved at de er immaterielle, heterogene, de konsumeres på samme tid som de produseres og kan ikke lagres (Trott, 2008). For det andre skapes opplevelser og vurderinger av tjenester i stor grad i interaksjon mellom partene, eksempelvis mellom kunder og ansatte, eller mellom leverandør og forbruker av tjenestene. Tjenester handler altså i større grad om menneskelige opplevelser enn fysiske attributter, og menneskenes faglige og sosiale kompetanse er en viktig del av produksjonen. Dette er noen av grunnene til at tjenester er et område hvor bedrifter kan differensiere seg og ta bedre betalt over tid (Carlin et al., 2015). Digitalisering gjør at tilgangen på ny, innovativ teknologi for å levere tjenester synes nesten uendelig. Stadig flere ledere stilles dermed overfor krevende beslutninger; ikke bare må de beslutte om de skal ta i bruk nye teknologiske løsninger, men med stadig flere alternativer å velge mellom må de også beslutte hvilke teknologiske løsninger de eventuelt skal velge og hvordan de skal implementere løsningene. Mulighetene strekker seg fra små, inkrementelle justeringer av dagens løsninger og prosesser til radikale endringer som utfordrer nåværende måte å jobbe og organisere virksomheten på, eller i ytterste konsekvens utfordrer virksomhetens egenart, identitet, kultur og eksistens. Flere tjenester, for eksempel vikarformidling, regningsbetaling og bestilling av taxi, kan nå erstattes av apper. Ønske om å redusere kostnader og jobbe mer effektivt ser ut til å være viktige drivere av digitale innovasjonsprosesser (Gausdal, Czachorowski \& Solesvik, 2018). Siden tjenesteproduksjon tradisjonelt har vært svært personintensivt, har lønnskostnader vært den desidert største kostnaden. Mulighetene som den digitale kunnskapsbaserte teknologien gir til forenkling og forbedring, sammen med ønsket om å redusere kostnader, gjør at implementering av tjenesteteknologi vil kunne medføre både at jobbinnholdet til mange ansatte blir radikalt endret, og at andre ansatte blir erstattet med teknologi - slik at jobbene deres derfor blir borte. Dette stiller store og spesielle krav til implementeringen. Carlin et al. (2015) fremhever også betydningen av å dyrke en kultur for endringsledelse for å lykkes med å implementere tjenesteteknologi som gjør arbeidstakere overtallige, og peker blant annet på betydningen av høyt tillitsnivå som en positiv faktor. 
Radikale endringer i organisasjoner kan være teknologiske og/eller adaptive (Heifetz \& Linsky, 2002). Teknologiske endringer kan løses basert på organisasjonens nåværende kunnskap og eksisterende problemløsningsprosesser, mens adaptive endringer innebærer at organisasjonen og dens ansatte må endre måten de jobber på, noe som blant annet kan utløse frykt og motstand (Heifetz \& Linsky, 2002). Noe av denne motstanden kan skyldes reduksjon av psykologisk trygghet fordi ansatte er redde for at endringene vil gi dem redusert selvbilde og/eller status. Radikalt ny tjestesteteknologi handler definitivt om teknologiske endringer, men kan også omfatte adaptive endringer, for eksempel hvis jobbinnholdet endres radikalt, eller ansattes oppgaver erstattes av teknologi.

\section{Drøfting: hva betyr tillit og psykologisk trygghet for implementering av radikalt ny tjenesteteknologi?}

For at ledere skal fremstå som viktige endringsagenter, er de avhengige av å ha legitimitet hos de ansatte som faktisk skal gjennomføre endringene (Huy et al., 2014). Vi hevder at slik legitimitet er viktig, både ved teknologiske og adaptive endringprosesser. Utvikling av slik legitimitet er en dynamisk og flerdimensjonal prosess, hvor både emosjonelle, kognitive og relasjonelle faktorer spiller sammen og over tid skaper en helhetlig oppfatning av ledelsens legitimitet, som igjen har betydning for implementeringen av radikal endring (Huy et al., 2014). Lederes legitimitet handler om i hvilken grad ansatte aksepterer deres rett til å fatte beslutninger, og i hvilken grad de vil innrette seg etter disse beslutningene (Tost, 2011). I hvilken grad slik legitimitet oppstår, påvirkes blant annet av graden av tillit mellom leder og ansatte og graden av psykologisk trygghet i organisasjonen. Ved adaptive endringsprosesser er det også viktig at ledere viser forståelse for det tapet endringen kan påføre de ansatte (Heifetz \& Linsky, 2002). Videre er det viktig at ledere bidrar til at ansatte bruker og utvikler sine kompetanser og ferdigheter for å håndtere endringene (Yukl \& Mahsud, 2010). Etter vår vurdering tar den siste av disse lederatferdene opp evne-dimensjonen av tillit, mens begge atferdene omhandler benevolens-dimensjonen av tillit. 
I endringslitteraturen trekkes gjerne et skille mellom to hovedtradisjoner for implementering av endring: Top-down- eller bottom-uptilnærminger (Matland, 1995). Tilsvarende inndeling finner vi også i studier av tjenesteinnovasjon (Engen, 2016). Hver av de to tilnærmingene har sine fordeler og utfordringer. En top-down-tilnærming gjør gjerne at endringen kan gjennomføres raskere og mer likt på tvers av hele organisasjonen, og prosessen oppleves som klart og tydelig definert (Balogun \& Hailey, 2008). Samtidig kan top-down-prosesser redusere eierskap og forankring, man risikerer å få løsninger som er for standardiserte og lite tilpasset ulike behov i ulike deler av virksomheten, samt at organisasjonen kan gå glipp av viktig innsikt fra lavere nivåer i virksomheten, eksempelvis fra førstelinjen som møter kunder ofte og dermed kan fange opp strategiske signaler derfra tidlig. En bottom-up-prosess har både motsatt startpunkt og logikk (Balogun \& Hailey, 2008, s. 32). Den gir sterkere eierskap og forankring på lavere nivår i organisasjonen. Samtidig er bottom-up-prosesser ofte mindre forutsigbare og tar gjerne lenger tid. I praksis finner man også kombinasjoner av de to tilnærmingene. I vår drøfting velger vi likevel å ta utgangspunkt i de to rene tilnærmingene for å synliggjøre betydningen av tillit og psykologisk trygghet så klart som mulig innenfor hver dem.

For at en klassisk top-down-implementering skal foregå på en god måte, er det er forutsetning at de ansatte har tillit til ledelsens beslutninger; de må ha høy tillit til at beslutningene er kloke, og gjennomføre implementeringen slik ledelsen har bestemt. Dette fordrer at de ansatte både har tillit til leder (personlig tillit) og tillit til beslutningen, inkludert prosessen og kompetansen som ligger bak beslutningen. Samtidig må ledelsen ha en viss grad av tillit til at de ansatte faktisk implementerer den nye teknologien slik det er besluttet. Ledelsen har riktignok formell posisjonsmakt til å kunne ilegge sanksjoner dersom implementeringen ikke gjennomføres som besluttet, men det vil over tid gi redusert tillitsnivå og komplisere fremtidige endringsprosesser.

Ved rene top-down-implementeringsprosesser risikerer man imidlertid at ansatte enten ikke forstår eller ikke er enige i hvilken teknologi som skal implementeres, eller hvordan det skal gjøres. Det kan medføre fare for at implementeringen ikke går som planlagt, eksempelvis fordi de 
ansatte handler ut fra egen (mis)forståelse av hva man «egentlig» ønsker å oppnå (Gioia \& Chittipeddi, 1991), eller lar være å engasjere seg i hele implementeringsprosessen. I team eller avdelinger preget av høyere psykologisk trygghet, vil de ansatte imidlertid i større grad tørre å gi uttrykk for hva de egentlig mener, stille flere oppklarende spørsmål og tørre å be om hjelp dersom de ikke forstår eller mestrer den nye teknologien med det samme (Edmondson \& Lei, 2014). Ansatte i team med høyere psykologisk trygghet vil også i større grad tørre å videreformidle egne erfaringer (gode og dårlige), samt videreformidle tilbakemeldinger og input fra andre relevante brukere av teknologien. Samtidig kan man stille spørsmål ved om enkelte ansatte i team preget av særdeles høy psykologisk trygghet vil tillate seg å stille for mange kritiske spørsmål, og slik utfordre både beslutningen og prosessen i et slikt omfang at man risikerer å forsinke implementeringsprosessen. Dermed mister man noen av hovedfordelene ved top-down-prosesser; nemlig hurtige, tydelig definerte og felles prosesser. For høy grad av tillit til ledelsen kan også medføre naivitet, og at de ansatte ikke stiller kritiske spørsmål eller deler kunnskap som kan medføre bedre resultater.

For at en klassisk bottom-up-implementering skal foregå på en god måte, er det viktig at det er høy grad av tillit og psykologisk trygghet blant både ansatte og ledere, fordi det innebærer risisko og usikkerhet. Ledere må være trygge nok på seg selv og ha høy nok tillit til de ansatte til å ta sjansen på å gi fra seg formell makt og innflytelse over implementeringsprosessen, og tåle den uforutsigbarheten som karakteriserer nettopp bottom-up-prosesser. Samtidig krever denne typen implementeringsprosesser at de ansatte opplever høyt nok nivå av psykologisk trygghet til å tørre ta på seg ansvaret, uten å være redde for å bli latterliggjort eller ydmyket dersom de ikke lykkes. Høy grad av tillit og psykologisk trygghet fremmer læring og utforskning, noe som er ekstra viktig for å lykkes dersom man implementerer ny teknologi gjennom en bottom-up-prosess.

Dersom et team eller avdeling er preget av lav tillit eller psykologisk trygghet, vil ansatte ofte være mer tilbakeholdne med å dele egne erfaringer, synspunkter eller komme med forslag. I en klassisk bottom-upprosess vil de negative konsekvensene dette medfører være ekstra 
skadelige, siden de ansatte har større ansvar for å utforme en god prosess og dermed har ekstra behov for tilgang på relevant erfaring og innsikt (Balogun \& Hailey, 2008; Matland, 1995).

Vi argumenterer derfor for at tillit og psykologisk trygghet er viktig for implementering av radikalt ny teknologi, blant annet fordi det påvirker lederens legitimitet. Vi ser også at tillit og psykologisk trygghet er viktig for både top-down- og bottom-up-implementeringer, men at de spiller noe ulik rolle i de to tilnærmingene. En god top-downimplementering forutsetter at de ansatte både har tillit til leder og til beslutningen, og at ledelsen har tillit til at de ansatte faktisk implementerer den nye teknologien slik det er bestemt. Videre vil høyere nivå av psykologisk trygghet medføre at de ansatte i større grad gir uttrykk for hva de egentlig mener og tør be om hjelp for å forstå og/eller mestre den nye teknologien. For høy grad av tillit og psykologisk trygghet kan imidlertid medføre 1) mangel på motstand og innspill som kan gjøre implementeringen bedre, for eksempel på grunn av gruppetenking og/ eller naivitet og 2) at det stilles for mange spørsmål som bidrar til å forsinke implementeringsprosessen. En god bottom-up-implementering forutsetter også høy grad av psykologisk trygghet blant både ansatte og ledere. Siden lederne her gir fra seg makt til de ansatte forutsetter den imidlertid at ledelsen har enda høyere tillit til de ansatte enn ved en topdown prosess. Videre forutsetter slike bottom-up-prosesser at de ansatte har høyt nok nivå av tillit og psykologisk trygghet til egen kompetanse. Høy grad av tillit mellom de ansatte og høy psykologisk trygghet fremmer begge erfaringsdeling, læring og utforskning, som er ekstra viktig i bottom-up-prosesser.

Vi har nå drøftet implementering av radikale endringer i organisasjoner i den konseptuelle casen radikalt ny tjenesteteknologi. Det kan diskuteres hvorvidt dette kan generaliseres til radikale endringer generelt. Siden tjenesteproduksjon tradisjonelt har vært så personintensivt, og at endringer her kan få så store konsekvenser for de ansattes jobb og jobbinnhold, og dermed kan defineres som adaptive endringer, har vi definert dette som en building block-case. Det vil si et spesielt fenomen som kan bidra til å identifisere felles mønstre (George \& Bennett, 2005) også for andre typer radikale endringer. 


\section{Avsluttende bemerkninger}

Det første forskningsspørsmålet i dette kapittelet er Hva er forskjellene og likhetene mellom begrepene tillit og psykologisk trygghet? Svaret på dette er at forskjellene blant annet består i at tillit er en antecedent, eller forløper, for psykologisk trygghet, og at psykologisk trygghet i liten grad omfatter evner. Siden psykologisk trygghet bygger på tillit er det flere åpenbare likheter, blant annet at siden graden av psykologisk trygghet bygger på noen dimensjoner av tillit, vil de sannsynligvis samvariere i relativt stor grad. De dimensjonene av tillit som ligger nærmest psykologisk trygghet og ser ut til å være en forløper for denne, er velvilje og til dels integritet. Andre likheter er at både tillit og psykologisk trygghet er situasjonsavhengige og har et optimalt nivå, det vil si at for høy grad kan ha negativ effekt. Videre at begge kan være flernivåbegreper, og at begge antageligvis også er flerdimensjonale begreper.

Det andre forskningsspørsmålet er Hvordan påvirker tillit og psykologisk trygghet implementering av radikale endringer i organisasjoner? Svaret på dette er først at tillit påvirker implementeringen gjennom legitimitet. Dette fordi legitimitet, spesielt lederens legitimitet hos de ansatte, er viktig i implementeringsprosesser, og ansattes tillit til lederen påvirker lederens legitimitet overfor de ansatte positivt (dvs. at legitimitet øker når tilliten øker). Videre finner vi at tillit og psykologisk trygghet spiller en noe ulik rolle avhengig av hvorvidt implementeringene foregår top-down eller bottom-up.

For at en klassisk top-down-implementering skal foregå på en god måte, er det viktig at de ansatte har høy tillit til ledelsen og til beslutningen om hvordan implementeringen skal foregå. Samtidig må ledelsen ha en viss grad av tillit til at de ansatte gjennomfører sin del av implementeringsjobben. Videre vil høyt nivå av psykologisk trygghet medføre at de ansatte i større grad gir uttrykk for hva de mener, bringer inn sin kunnskap og tør be om hjelp for å forstå og mestre den nye teknologien. For høy grad av tillit og psykologisk trygghet kan imidlertid medføre mangel på motstand og innspill som kunne gjort implementeringen bedre, og for mange spørsmål som kan forsinke implementeringsprosessen.

En god bottom-up-implementering forutsetter høy grad av psykologisk trygghet blant både ansatte og ledere. Siden lederne her gir fra 
seg makt til de ansatte, forutsetter den imidlertid at ledelsen har enda høyere tillit til de ansatte enn ved top-down-implementeringer. Videre forutsetter bottom-up-prosesser at de ansatte har høy nok tillit til egen kompetanse. Høy grad av tillit mellom de ansatte og psykologisk trygghet fremmer begge erfaringsdeling, læring og utforskning, som er ekstra viktig i bottom-up-prosesser.

Denne studien viser også behov for mer forskning. Først og fremst er det behov for å teste sammenhengene og funnene i denne studien med empiriske studier. Våre funn i dette kapitlet er utledet gjennom teoretiske diskusjoner. Gjennom empiriske studier vil man både kunne videreutvikle forståelsen for sammenhenger mellom begrepene, og teste de antatte sammenhengene vi fremsetter i dette kapitlet. Videre er det behov for å forske mer på hvordan psykologisk trygghet oppstår og fungerer i forbindelse med radikale og adaptive endringer på flere nivåer enn gruppenivå, for eksempel på organisasjons-, interorganisatorisk og nettverks-nivå (Newman et al., 2017). Det er også behov for å forske mer, spesielt longitudinelle studier, på den krevende prosessen det er å lede adaptive endringsprosesser (Yukl \& Mahsud, 2010). Det er videre behov for å studere om og hvordan det vi finner i casen radikalt ny tjenesteteknolgi fungerer som building block for andre typer radikale og adaptive endringer. Det er også behov for mer forskning på sammenhengene og forskjellene mellom psykologisk trygghet og tillit. Det vil blant annet være interessant å undersøke om psykologisk trygghet består av flere dimensjoner, slik som tillit, samt analysere hvilke dimensjoner som eventuelt har størst betydning for implementering av radikale og adaptive endringer.

Gitt den voldsomme økningen i endringer som implementeres på stadig nye områder, er ytterligere studier på dette området relevant og interessant både fra et praktisk og et teoretisk perspektiv.

\section{Referanser}

Andersen, E. \& Sannes, R. (2017). Hva er digitalisering? Magma, 2o(6), 18-24. Hentet fra http://hdl.handle.net/11250/2569870

Andreassen, T. W. \& Kristensen, I. H. (2019). Rustet for digital tjenesterevolusjon. Magma, 2, 109-109. Hentet fra https://www.magma.no/rustet-for-digitaltjenesterevolusjon 
Balogun, J. \& Hailey, V. H. (2008). Exploring strategic change. New York: Pearson Education.

Bygstad, B. \& Iden, J. (2017). Styringsmodeller for digitalisering. Magma, 6, 25-32. Hentet fra https://www.magma.no/styringsmodeller-for-digitalisering

Carlan, V., Coppens, F., Sys, C., Vanelslander, T. \& VanGaste, G. (2019) Blockchain technology as key contributor to the integration of maritime supply chain? I

T. Vanelslander \& C. Sys (Red.), Maritime supply chains (s. 229-259). https://doi. org/10.1016/B978-0-12-818421-9.00012-4

Carlin, M. S., Skjellaug, B., Nygaard, S., Vermesan, O., Svagård, I. S., Andreassen, T. W. ... Boysen, E. S. (2015). Effekter av teknologiske endringer på norsk næerings- og arbeidsliv (SINTEF Rapport A27222). Hentet fra http://hdl.handle. net/11250/2378812

Carmeli, A., Brueller, D. \& Dutton, J. E. (2009). Learning behaviours in the workplace: The role of high-quality interpersonal relationships and psychological safety. Systems Research and Behavioral Science, 26(1), 81-98. https://doi.org/ $10.1002 /$ sres.932

Daazenko, S. \& Grønquist, D. N. (2016). Økonomiske effekter av tjenesteinnovasjon. Magma, 7, 54-63. Hentet fra https://www.magma.no/okonomiske-effekteravtjenesteinnovasjon

Edmondson, A. C. (2004). Learning from mistakes is easier said than done: Group and organizational influences on the detection and correction of human error. The Journal of Applied Behavioral Science, 4o(1), 66-90. https://doi.org/10.1177/ 0021886304263849

Edmondson, A. C., Bohmer, R. M. \& Pisano, G. P. (2001). Disrupted routines: Team learning and new technology implementation in hospitals. Administrative Science Quarterly, 46(4), 685-716. https://doi.org/10.2307/3094828

Edmondson, A. C. \& Lei, Z. (2014). Psychological safety: The history, renaissance, and future of an interpersonal construct. Annual Review of Organizational Psychology and Organizational Behavior, 1(1), 23-43. https://doi.org/10.1146/ annurev-orgpsych-031413-091305

Engen, M. (2016). Frontline employees as participants in service innovation processes: Innovation by weaving (Doktorgradsavhandling, Høgskolen i Lillehammer). Hentet fra http://hdl.handle.net/11250/2387044

Frazier, M. L., Fainshmidt, S., Klinger, R. L., Pezeshkan, A. \& Vracheva, V. (2017). Psychological safety: A meta-analytic review and extension. Personnel Psychology, 7o(1), 113-165. https://doi.org/10.1111/peps.12183

Fulmer, C. A. \& Gelfand, M. J. (2012). At what level (and in whom) we trust: Trust across multiple organizational levels. Journal of Management, 38(4), 1167-1230. https://doi.org/10.1177/0149206312439327 
Gausdal, A. H., Czachorowski, K. V. \& Solesvik, M. Z. (2018). Applying blockchain technology: Evidence from Norwegian companies. Sustainability, 10(6), $16 \mathrm{s.}$ https://doi.org/10.339o/su10061985

George, A. L. \& Bennett, A. (2005). Case studies and theory development in the social sciences. Cambridge, MA: MIT Press.

Gillespie, N. (2003, august). Measuring trust in working relationships: the behavioural trust inventory.

Gillespie, N. (2003, august). Measuring trust in working relationships: The behavioural trust inventory. Paper presentert på møte i Academy of Management, Seattle.

Gioia, D. A. \& Chittipeddi, K. (1991). Sensemaking and sensegiving in strategic change initiation. Strategic Management Journal, 12(6), 433-448. https://doi. org/10.1002/smj.4250120604

Heifetz, R. A. \& Linsky, M. (2002). A survival guide for leaders. Harvard Business Review, 8o(6), 65-74. Hentet fra https://hbr.org/2002/06/a-survival-guide-forleaders

Hoff, K. A. \& Bashir, M. (2014). Trust in automation: Integrating empirical evidence on factors that influence trust. Human Factors: The Journal of the Human Factors and Ergonomics Society, 57(3), 407-434. https://doi.org/10.1177/0018720814547570

Huy, Q. N., Corley, K. G. \& Kraatz, M. S. (2014). From support to mutiny: Shifting legitimacy judgments and emotional reactions impacting the implementation of radical change. Academy of Management Journal, 57(6), 1650-168o. https://doi. org/10.5465/amj.2012.0074

Jarzabkowski, P., Lê, J. \& Balogun, J. (2019). The social practice of coevolving strategy and structure to realize mandated radical change. Academy of Management Journal, 62(3), 850-882. https://doi.org/10.5465/amj.2016.0689

Jensen, M. B., Johnson, B., Lorenz, E. \& Lundvall, B. Å. (2007). Forms of knowledge and modes of innovation. Research Policy, 36(5), 680-693. https://doi. org/10.1016/j.respol.2007.01.006

Kahn, W. A. (1990). Psychological conditions of personal engagement and disengagement at work. Academy of Management Journal, 33(4), 692-724. https:// doi.org/10.5465/256287

Levinthal, D. A. \& March, J. G. (1993). The myopia of learning. Strategic Management Journal, 14, 95-112. https://doi.org/10.1002/smj.4250141009

Li, P. P. (2011). The rigour-relevance balance for engaged scholarship: New frame and new agenda for trust research and beyond. Journal of Trust Research, 1(1), 1-21. https://doi.org/10.1080/21515581.2011.550718

March, J. G. (1991). Exploration and exploitation in organizational learning. Organization Science, 2(1), 71-87. https://doi.org/10.1287/orsc.2.1.71

Matland, R. E. (1995). Synthesizing the implementation literature: The ambiguityconflict model of policy implementation. Journal of Public Administration Research and Theory: J-PART, 5(2), 145-174. http://www.jstor.org/stable/1181674 
Maurer, I. (2010). How to build trust in inter-organizational projects: The impact of project staffing and project rewards on the formation of trust, knowledge production and product innovation. International Journal of Product Management, 28(7), 629-637. https://doi.org/10.1016/j.ijproman.2009.11.006

Mayer, R. C., Davis, J. H. \& Schoorman, F. D. (1995). An integrative model of organizational trust. Academy of Management Review, 20(3), 709-734. https://doi. org/10.5465/AMR.1995.9508080335

McFall, L. (1987). Integrity. Ethics, 98(1), 5-20. https://doi.org/10.1086/292912

Newman, A., Donohue, R. \& Eva, N. (2017). Psychological safety: A systematic review of the literature. Human Resource Management Review, 27(3), 521-535. https://doi.org/10.1016/j.hrmr.2017.01.001

Miles, R., Miles, G. \& Snow, C. C. (2005). Collaborative entrepreneurship. Redwood City, CA: Stanford University Press.

Nonaka, I., Toyama, R. \& Konno, N. (2000). SECI, Ba and leadership: A unified model of dynamic knowledge creation. Long Range Planning, 33(1), 5-34. https:// doi.org/10.1016/Soo24-6301(99)oo115-6

O'Reilly III, C. A. \& Tushman, M. L. (2013). Organizational ambidexterity: Past, present, and future. Academy of Management Perspectives, 27(4), 324-338. https:// doi.org/10.5465/amp.2013.0025

Polanyi, M. (1983). The tacit dimension. London: Routledge \& Kegan Paul. (Utgitt 1966.)

Randhawa, K. \& Scerri, M. (2015). Service innovation: A review of the literature. I R. Agarwal, W. Selen, G. Roos \& R. Green (Red.), The handbook of service innovation (s. 27-51). https://doi.org/10.1007/978-1-4471-6590-3_2

Roussin, C. J., MacLean, T. L. \& Rudolph, J. W. (2016). The safety in unsafe teams: A multilevel approach to team psychological safety. Journal of Management, 42(6), 1409-1433. https://doi.org/10.1177/0149206314525204

Shazi, R., Gillespie, N. \& Steen, J. (2015). Trust as predictor of innovation network ties in project teams. International Journal of Project Management, 33(1), 81-91. https://doi.org/10.1016/j.ijproman.2014.06.001

Svare, H., Gausdal, A. H. \& Möllering, G. (2020). The function of ability, benevolence, and integrity-based trust in innovation networks. Industry and Innovation, 27(6), 585-604. https://doi.org/10.1080/13662716.2019.1632695

Tost, L. P. (2011). An integrative model og legitimacy judgments. The Academy of Management Review, 36(4), 686-710. https://doi.org/10.5465/amr.2010.0227

Trott, P. (2008). Innovation management and new product development. New York: Pearson Education.

Tushman, M. L. \& O’Reilly III, C. A. (1996). Ambidextrous organizations: Managing evolutionary and revolutionary change. California Management Review, 38(4), 8-30. https://doi.org/10.2307/41165852 
Tödtling, F., Asheim, B. \& Boschma, R. (2013). Knowledge sourcing, innovation and constructing advantage in regions of Europe. European Urban and Regional Studies, 2o(2), 161-169. https://doi.org/10.1177/0969776412457173

Vaida, S. (2019). Psychological safety and trust. A conceptual analysis. Studia Universitatis Babeș-Bolyai Psychologia-Paedagogia, 64(1), 87-101. https://doi. org/10.24193/subbpsyped.2019.1.05

von Krogh, G. Ichijo, K. \& Nonaka, I. (2000). Enabling knowledge creation: How to unlock the mystery of tacit knowledge and release the power of innovation. Cambridge, MA: Oxford University Press.

Yukl, G. \& Mahsud, R. (2010). Why flexible and adaptive leadership is essential. Consulting Psychology Journal: Practice and Research, 62(2), 81-93. https://doi. org/10.1037/aoo19835

Zhang, Y., Fang, Y., Wei, K.-K. \& Chen, H. (2010). Exploring the role of psychological safety in promoting the intention to continue sharing knowledge in virtual communities. International Journal of Information Management, 30(5), 425-436. https://doi.org/10.1016/j.ijinfomgt.2010.02.003 



\title{
KAPITTEL 11
}

\section{Hvorfor er effektiv ledelse så sjelden?}

\section{Helene Tronstad Moe}

\section{Høyskolen Kristiania}

\begin{abstract}
Leaders do not always lead effectively. Barriers to effective leadership exist both within organizations and within every human being. Barriers to effective leadership may cause organizations to select the wrong people for high-ranking positions, and may be an important reason for organizational ineffectiveness, poor group dynamics and lack of self-regulation. One plausible explanation for the existence of such barriers is fluctuations in hormone levels among leaders and followers, a hypothesis that needs further study. Levels of testosterone, cortisol, adrenaline and oxytocin are of interest, and longitudinal studies correlating hormone data with measures of leadership effectiveness are one way of establishing why leaders do not more often utilize effective leadership techniques. Hormone analysis technology has advanced tremendously in recent years, and low-barrier testing may be conducted for some of these hormones by extracting saliva samples in near real-life scenarios.
\end{abstract}

Keywords: leadership effectiveness, hormone data, barriers to effective leadership, testosterone, cortisol

\section{Introduksjon}

Lederskap er en generell menneskelig atferd (Bass \& Stogdill, 1990; Hollander, 1985), og menneskelige hierarkier ligner andre primaters sosiale rangordninger (Sapolsky, 2017). Begrepet lederskap er definert på forskjellige måter. En vanlig definisjon er ledelse som utøvelse av innflytelse over andre for å nå visse mål. Yukl definerer ledelse som prosessen med å 
påvirke andre til å forstå og være enige om hva som må gjøres og hvordan man skal gjøre det, og prosessen med å tilrettelegge for individuelle og kollektive bestrebelser for å oppnå delte mål (2013, s. 7).

Psykologifeltet gir oss normative svar på spørsmålet om hva som utgjør effektiv leder- og organisasjonsutvikling. Denne artikkelen vil peke på diskrepansen mellom de enorme mengdene forskning og ledelsesteorier som forteller oss hva som er adekvat ledelsesatferd, og lederes faktiske rolleutøvelse. Med andre ord: Hvorfor gjør ikke ledere i praksis det de har lært gjennom utdanning og kursing - hvorfor er effektiv ledelse så sjelden? Det er mulig at forklaringen av dette misforholdet ligger i milj$ø$ kompleksitet eller ulike bias knyttet til læring, men dette kapittelet vil hevde at den underliggende forklaringen kan ligge et annet sted, nemlig i praksis. I dette kapittelet vil noen årsaker til lederineffektivitet bli gjennomgått. Deretter vil ulike barrierer for effektivt lederskap som eksisterer både i organisasjoner og individer diskuteres. Slike barrierer kan føre til at organisasjoner ikke velger de rette menneskene til høyere lederstillinger, og kan være en viktig årsak til organisatorisk ineffektivitet, dårlig gruppedynamikk og mangel på selvregulering. En plausibel forklaring på eksistensen av slike barrierer er svingninger i hormonnivåer blant ledere og medarbeidere. Kapittelet bidrar med å forklare at dårlig eller ineffektivt lederskap ikke er et resultat av dårlige intensjoner eller manglende kunnskap om adekvat lederatferd, men snarere et resultat av et komplekst samspill mellom biologiske, hormonelle og situasjonelle faktorer.

Litteraturen inkluderer mange teorier og funn om effektivt lederskap, og antyder trekk, egenskaper, ferdigheter og atferd hos effektive ledere (Antonakis \& Day, 2018). Yukl (2013) hevder for at kjennetegn ved effektivt lederskap er evnen til å tolke betydningen av hendelser; bygge engasjement; optimisme; gjensidig tillit og samarbeid; styrke kollektiv identitet; organisere aktiviteter; legge til rette for kollektiv læring; skaffe ressurser; utvikle og styrke mennesker; sosial rettferdighet; moralske standarder. Et annet eksempel på effektiv lederatferd er transformasjonsledelse (Bass, 1985, 1996; Burns, 1978; Hoch, Bommer, Dulebohn \& Wu, 2018). Transformasjonsledelse viser til en lederatferd som viser tillit, lojalitet og respekt, og følgelig inspirerer folk til å gjøre mer enn det som ellers kunne vært tilfelle. 
Nye organisasjonsformer har blitt utforsket de siste tiårene, for eksempel flate organisasjoner, holakrati, mentorordninger og empatiske organisasjoner. Effektiv ledelse ser imidlertid ut til å være et ideal som er vanskelig å realisere. Arbeidsmiljøundersøkelser viser ofte at $60-70 \%$ av de ansatte opplever stress i kommunikasjonen med lederne sine (Hogan, 2006), og rundt $60 \%$ av amerikanske ledere mislykkes i rollene sine (Hogan \& Kaiser, 2005). Ineffektiv ledelse kan delvis forklare hvorfor bare $30 \%$ av de ansatte er opptatt av arbeidet sitt, $50 \%$ er ikke-engasjerte og $20 \%$ kan karakteriseres som kontraproduktive - dvs. at de bidrar negativt (Gallup, 2013). En studie fra Storbritannia fant at bare $43 \%$ av de ansatte var fullt ut engasjert i arbeidet sitt (TUC, 2008). En annen undersøkelse i Storbritannia viste at $70 \%$ av de ansatte hadde forlatt en jobb på grunn av lederen, og at $54 \%$ av de spurte på et tidspunkt hadde hatt et problem med lederens lederstil (Telfer, 2013). I Norge avslørte en undersøkelse at $34 \%$ av de ansatte ikke var fornøyd med resultatene til lederne sine (Ennova, 2013).

\section{Hvorfor er så mange ledere ineffektive?}

En plausibel forklaring på omfanget av ulike grader av ineffektiv ledelse kan være miljøkompleksitet. Det er ikke samsvar mellom de idealiserte ledelsesscenariene fra teoriene om effektivt lederskap, og lederes hverdagssituasjon (Alvesson, 2019; Carlson, 1991; Luthans, Hodgetts \& Rosenkrantz, 1988; Mintzberg, 1973; Stewart 1988; Tengblad, 2013). Man kan hevde at mange av disse modellene er av begrenset verdi i lederes hverdagsliv, hvor de må takle forskjellige krav samt stor grad av kompleksitet og usikkerhet på daglig basis. Ledelse skjer oftere i miljøer der det foreligger motstridende forventninger, og hvor lederens arbeid er mer preget av usikkerhet, fragmentering og et hektisk tempo, enn av orden og kontroll (Tengblad, 2013). Ifølge Alvesson (2019) må ledelsesstudier være mer realistiske, og diskutere problemer som kognitive bias, kognitiv dissonans og tautologier i stedet for elitisme og ukritisk produksjon og reproduksjon av leder-tilhenger-identiteter.

En annen mulig forklaring på utbredelsen av ineffektiv ledelse kan være mangel på riktig ledertrening og utdanning. En forklaring relatert 
til mangelen på riktig ledertrening forutsetter at ledelse er noe som kan kodes, oppsummeres, pakkes og læres i løpet av relativt kort tid. I treningsprogrammer blir ledelse ofte presentert som en ordnet og kontrollerbar aktivitet. En slik antakelse kan kritiseres, da ledelse heller bør forstås som en kreativ handling som både ledere og underordnede er forberedt på og skolert til gjennom livslang læring (Kellerman, 2012). Men selv om dette var tilfellet, har forskning vist at til tross for at ledere vet hva de bør gjøre i teorien, er de ikke nødvendigvis i stand til å overføre denne kunnskapen til virkelige situasjoner (Pfeffer \& Sutton, 200o). Dweck (2006) konkluderte med at menneskers iboende ønske om å vise det de kan har en tendens til å forårsake fastlåste tankesett blant ledere - som igjen kan hindre dem i å lære av feil og videreutvikle seg. Ifølge Dweck har ledere en tendens til å bruke styrkene sine for å oppnå raske resultater, uten å ta sine egne svakheter i betraktning.

Ledere er ikke alltid i stand til å transformere medarbeidernes innsats, motivasjon og engasjement til koordinerte, målrettete handlinger. De skaper ikke alltid organisatorisk likestilling, og bygger heller ikke alltid engasjement, gjensidig tillit eller samhold (Cardona, 200o; Kotter, 1999; Rose, Shuck, Twyford \& Bergman, 2015). Ledertrening som sikrer at ledere innehar de nødvendige ferdigheter og kunnskaper om hvordan man kan praktisere effektiv ledelse har blitt foreslått (Breaux, Perrewé, Hall, Frink \& Hochwarter, 2008; Harris, Harvey \& Kacmar, 2011), men lederopplæring har fremdeles et begrenset anvendelsesområde (Rose et al., 2015).

Det kan derfor hevdes at forskere stiller feil spørsmål knyttet til ledelse. I stedet for å spørre hva det er som utgjør effektivt lederskap, vil det kanskje være mer interessant å spørre: Gitt all kunnskapen knyttet til hva som utgjør effektivt lederskap, hvorfor er så få ledere i stand til å lede effektivt? (Karp, 2018).

Birkinshaw (2013) stilte et lignende spørsmål, og argumenterte for at det er et misforhold mellom ledelsesretorikk og virkelighet. Birkinshaws råd til ledere er at de skal imøtekomme behovene til de ansatte, som opprinnelig anbefalt av Greenleaf (1977). Medarbeiderskap og lederskap har endret seg over tid. På grunn av kulturell evolusjon og teknologiske revolusjoner har maktbalansen mellom medarbeidere og ledere endret seg. 
De som blir ledet har blitt betydelig sterkere, og lederne har blitt svekket i løpet av de siste 40 årene (Kellerman, 2012).

Psykologifeltet har gitt oss normative anbefalinger for hvordan vi kan optimalisere lederutdanning og organisasjonsutvikling, men har ikke tatt opp misforholdet mellom teoretiske anbefalinger og ledernes evne til å prestere i det virkelige liv. Så hvorfor anvender ikke ledere ferdighetene som er nødvendige for effektivt lederskap i dag? I det følgende vil forskjellige barrierer for å praktisere effektivt lederskap diskuteres.

\section{Barrierer for effektivt lederskap}

Det eksisterer hindringer for effektivt lederskap i moderne organisasjoner og, enda viktigere, i ethvert menneske. Evolusjonspsykologi, utviklingspsykologi og de raskt voksende fagområdene nevrovitenskap og endokrinologi kan gi relevant innsikt. Ved å benytte disse fagfeltene som referanse, vil jeg argumentere for at det eksisterer barrierer som forhindrer utøvelse av effektiv lederatferd i moderne organisasjoner. Mulige barrierer for effektivt lederskap inkluderer ønsker om å dominere andre, manglende evne til å takle stress og press, utilstrekkelige sosiale ferdigheter, utilstrekkelige kommunikasjonsferdigheter, ulike bias i beslutningsprosesser samt mangel på selvdisiplin. Jeg vil diskutere disse mulige hindringene individuelt og vurdere dem opp mot effektiv ledelse.

\section{Et ønske om å dominere andre}

De fleste ledelsesforskere er enige om at et ønske om makt er en ønskelig kvalitet hos en leder, men en leders effektivitet avhenger også av hvordan dette ønsket kommer til uttrykk. Eksperimenter i sosialpsykologi har vist at maktmisbruk kan oppstå når mennesker får økt makt (Kipnis, 1972; Lammers, Galinsky, Gordijn \& Otte, 2008; Milgram, 1963). Slike overtramp kan finne sted når ledere øker eller konsoliderer sitt maktgrunnlag, og kommer til syne gjennom korrupsjon, bestikkelser, nepotisme eller ved å gi fordeler til mennesker som står dem nær. Forskning indikerer at ledere kan initiere en konflikt hvis de tror at deres stilling er truet (Padilla, Hogan \& Kaiser, 2007), og studier viser også at ledere 
har en tendens til å eliminere rivaler for å befeste sin stilling. I tillegg til overgrep, kan andre vanlige konsekvenser av dominans i organisasjoner inkludere tilbakeholdelse av informasjon, samt å klandre eller fordømme andre mennesker (Magee \& Galinsky, 2008; Nissen, 1945). Alle disse faktorene vil skape dårlige arbeidsmiljøer hvor de ansatte vil oppleve stress, angst, nedsatt produktivitet og ineffektiv ledelse. I moderne organisasjoner er ofte lønningene til topplederne mange ganger høyere enn for den gjennomsnittlige ansatte. Lederstillinger er ofte svært attraktive på grunn av de omfattende privilegiene, og et resultat av dette er at det er skarp konkurranse om disse stillingene. Denne konkurransen vil kunne favorisere dominerende ledere, selv om slike ledere ikke nødvendigvis vil ha effektive lederegenskaper (Padilla et al., 2007).

Når menn og kvinner jobber sammen i grupper, viser eksperimenter at menn er raskere med å hevde seg som ledere, selv når de ikke er kvalifiserte (Mezulis, Abramson, Hyde \& Hankin, 2004). Det er også mer sannsynlig at de inntar lederroller når de blir observert av kvinner (Jensen-Campbell, Gleason, Adams \& Malcolm, 2003). Makt ser også ut til å appellere til individer som er selvsentrerte, statusbesatte, følelsesmessig kalde og med en aggressiv personlighet. Forskning har vist at slike personlighetsprofiler uforholdsmessig ofte er representert blant ledere (Babiak \& Hare, 2009). Dominans motiverer ledere til å bruke tid og energi på å sammenligne seg med andre ledere og markere seg selv, i stedet for å arbeide for å bli mer effektive ledere (Dweck, 2006).

Forskning innen endokrinologi har vist at høye nivåer av testosteron er relatert til dominanstendenser hos både menn og kvinner (Archer, 2006; Colarelli \& Arvey, 2015; Eisenegger, Haushofer \& Fehr, 2011). Studier har vist at personer som får en økning i sosial status (f.eks. får en lederposisjon) reagerer generelt med en økning i testosteron og en reduksjon i kortisolnivåer (Mazur, 1985; Sherman et al., 2012). I møte med dominante statussignaler vil testosteron bidra til økt følelsesmessig årvåkenhet, men redusert oppmerksomhet som svar på underdanige signaler (Knight \& Mehta, 2014.) Den forskningen som foreligger per i dag antyder at testosteronnivåer påvirker en persons status-søkende motivasjon (Mehta, Jones \& Josephs, 2008). Mange forskere hevder også at ledere med høye testosteronnivåer mest sannsynlig vil ha vanskeligheter med å føle empati 
med andre (Josephs, Sellers, Newman \& Mehta, 2006; Ronay \& Carney, 2013). Testosteron kan muligens føre til antisosial atferd i en kontekst relatert til status og dominans (Zitzman \& Nieschlag, 2001). Funnene viser imidlertid også at atferd relatert til testosteron er kontekstuelt avhengig (Winslow, Ellingboe \& Miczek, 1988). Mens hormonet kan spille en rolle i konkurrerende og antisosial atferd når utfordringer og trusler er fremtredende, kan det også bidra til pro-sosial atferd som bidrar til høy status og et godt omdømme der slike utfordringer og trusler er fraværende (Boksem et al., 2013). Det har også vist seg at etter fylte 40 år begynner testosteronnivåene å synke både hos menn og kvinner (Feldman et al., 2002; Szulc, Hofbauer, Heufelder, Roth \& Delmas, 2001). Disse funnene kan gi et mer balansert syn på effekten av testosteron, og illustrerer at hormoner er dynamiske signaler koblet til sosial atferd og personlighetstrekk.

Interaksjon mellom mennesker har en tendens til å bli styrt av praktiske situasjoner snarere enn forutgående strategiske hensyn (Karp \& Johannessen, 2010). Derfor kan effektive ledere være de som kan reagere pragmatisk på en gitt situasjon som dukker opp, og som er i stand til å identifisere hva som må gjøres videre (Holmberg \& Tyrstrup, 2010). Et aktuelt perspektiv er at det ikke er noe samsvar mellom ønsket om å dominere andre og ønsket om å innta en lederposisjon. For eksempel har noen eksperimenter vist at de som scorer høyt på dominans ikke nødvendigvis ender opp som faktiske ledere (Kremer \& Mack, 1983). Andre studier har imidlertid funnet at ledere på en eller annen måte må dominere visse situasjoner for å kunne lede (Karp \& Johannesen, 2010). Fra et lederperspektiv er det forskjell mellom det å inneha et ønske om å dominere andre og det å øve innflytelse i spesifikke situasjoner hvor mennesker trenger veiledning.

\section{Manglende evne til å takle stress på arbeidsplassen}

Et stort antall studier innen ledelsesforskningen finner at stresstoleranse er assosiert med ledereffektivitet (Bass, 1990; Bass \& Bass, 2009; Howard \& Bray, 1988). Høy stresstoleranse hjelper ledere til å takle et hektisk tempo, lange arbeidsdager, motstridende forventninger og høye krav til leveranse. Når ledere opplever høy grad av stress, vil kroppene deres 
reagere med en kraftig økning i frigjøring av hormonene kortisol og adrenalin. Disse to hormonene interagerer, og kan resultere i en respons som innebærer økt blodsirkulasjon og det som populært kalles fight or flight-reaksjon (Sapolsky, 1999). Kortisolnivået varierer som en del av døgnrytmen, og er vanligvis på topp om morgenen når vi våkner og kroppen settes i aktivitet (Chung, Son \& Kim, 2011). Overeksponering for kortisol forstyrrer tilbakekoblingssløyfer, noe som fører til syklisk økende kortisolkonsentrasjoner og muligens dysfunksjonelle fysiologiske responser (Kamin \& Kartes, 2017). Det har vist seg at høy sosioøkonomisk status korrelerer med lave kortisolnivåer (f.eks. Garcia et al., 2008; Steptoe et al., 2003), noe man også har funnet hos militære ledere og næringslivsledere (Sherman et al., 2012).

En følelse av kontroll ser ut til å være viktig for lederne. Når de er under stress, kan mangel på kontroll føre til betydelig økning i produksjonen av kortisol (Dickerson \& Kemeny, 2004). Å være på toppen av et hierarki kan gi en følelse av kontroll (Fast, Greuenfeld, Siyanathan \& Galinsky, 2009), men ledere innehar imidlertid ikke alltid den grad av kontroll de tror de har (Tengblad, 2013). Mange ledere har et sterkt ønske om kontroll, og søker følgelig lederstillinger for å oppfylle dette behovet. De stiger ofte i gradene i organisasjoner fordi de i de tidlige stadiene av karrieren er i stand til å utøve kontroll (Binney, Wilke \& Williams, 2005). I teorien skal det å føle at man har kontroll dempe kortisolresponsen når man opplever en stressfaktor. Dette er det interne kontrollområdet: en evne som er relevant for ledereffektivitet (Rotter, 1966). Mennesker med en sterk indre overbevisning om at de har kontroll, tror at hendelser i deres liv blir bestemt av deres egne handlinger, snarere enn ved tilfeldigheter eller faktorer de ikke har kontroll over. Følelsen av indre kontroll over omstendigheter og menneskelige forhold kan altså redusere kortisolresponsen (Cohen et al., 2006; Sherman et al., 2012). Med andre ord, følelsen av kontroll kan ha en direkte effekt på en redusert produksjon av kortisol og de negative effektene dette kan føre til. Dette kan også være relatert til å opprettholde en følelse av optimisme og fleksibilitet ved eksponering for stressfaktorer; personer som innehar disse egenskapene har også vist seg å ha lavere kortisolproduksjon (Lindfors \& Lundberg, 2002; Ryff, Singer \& Love, 2004). Et sterkt internt kontrollområde korrelerer med 
ledereffektivitet, men kontroll over underordnede kan vise seg å være ineffektivt i organisasjoner (Falk \& Kosfeld, 2006).

Studier av effekten av testosteron og kortisol er likevel inkonsekvente fordi testosteron og kortisol kan interagere, og påvirke atferd. Testosteron er knyttet til atferd for å søke høyere status når nivåene av kortisol er lave (Mehta \& Josephs, 2011), men hvis kortisolnivåne er høye, vil testosteroneffekten av å søke høyere status bli forhindret. Forholdet mellom testosteron og kortisol kan også fortelle oss noe om oppnåelse av høy status gjennom dominans: Høye nivåer av testosteron korrelerer med dominans og høyere status blant personer med lave nivåer av kortisol, men ikke blant personer med høye nivåer av kortisol. Ut fra et evolusjonært perspektiv kan dette forklares med at stressende situasjoner begrenser effekten av testosteron på reproduktiv atferd, f.eks. konkurranse og dominans, fordi slik oppførsel kan være for krevende ut fra metabolske hensyn. Det er når stressnivået er lavt at atferd relatert til statussøking vil være av betydning.

\section{Mangel på sosiale ferdigheter}

Sosiale ferdigheter kan forstås som et flerdimensjonalt begrep bestående av følgende delvis integrerende, overlappende og supplerende komponenter: 1) samhandlingsferdigheter; 2) kommunikasjonsevner; 3) deltakelsesferdigheter; 4) emosjonelle ferdigheter; 5) ferdigheter i sosial erkjennelse (Jurevičiene, Kaffemaniené \& Ruškus, 2012). Forskning har vist at mellommenneskelige ferdigheter forbedrer effektiviteten av relasjonsorientert atferd (Yukl, 2013). I tillegg anses en leders evne til å veksle mellom henholdsvis oppgave, relasjonelt og endringsorientert atferd som effektiv (Hemphill \& Coons, 1957; Yukl, Gordon \& Taber, 2002).

Ledere har måttet tiltrekke seg og beholde tilhengere, og sosiale ferdigheter har hjulpet dem i denne forbindelse. Studier viser at oksytocin er positivt relatert til menneskelig interaksjon (Grewen, Girdler, Amico \& Light, 2005; Tops, van Peer, Korf, Wijers \& Tucker, 2007), selv om studier også viser at hormonet kan signalisere et ønske om mer menneskelig kontakt (Taylor et al., 2006; Turner, Altemus, Enos, Cooper \& McGuinness, 1999). Forskning har også indikert at hormonet øker tilliten, rausheten 
og samarbeidet i økonomiske beslutningsprosesser (Kosfeld, Heinrichs, Zak, Fischbacher \& Fehr, 2005), samt bidrar til en oppfatning av andres troverdighet (Zak, Kurzban \& Matzner, 2005). Eksogent oksytocin forbedrer kognisjonen, inkludert ansiktsgjenkjenning og empati (Lischke, 2013).

I sosiale sammenhenger ser det ut til at oksytocin bidrar til pro-sosial atferd overfor andre medlemmer i gruppen (de Dreu, 2012). Man finner for eksempel en tendens til at menn vil allokere egne ressurser til andre medlemmer i gruppen i konkurransepregede situasjoner, spesielt når et gruppemedlem er truet (de Dreu et al., 2010). Det synes også som om hormonet bidrar til å forbedre tilliten til at andre gruppemedlemmer vil respondere med lignende sjenerøse oppførsel, men det er ingen tilsvarende mistillit til mennesker som ikke tilhører gruppen. Denne omfattende pro-sosiale atferden kan indikere at et individs raushet og ressursbruk overfor gruppemedlemmer også kan bidra til at de øvrige gruppemedlemmene tildeler individet høyere altruistisk status (Hardy \& Van Vugt, 2006).

I sum indikerer tidligere studier at oksytocin har en positiv effekt med hensyn til prososial atferd i grupper, og forbedrer inn-gruppens status kontra øvrige grupper. I tillegg kan oksytocin påvirke en rekke sosiale faktorer som tillit, samarbeid, generøsitet, empati og sosial kognisjon som alle er egenskaper og atferd som er viktige for ledelse. Ledelsesforskning har gjentatte ganger bekreftet effektiviteten av slike sosiale ferdigheter uavhengig av situasjonen (Bass, 1990; Boyatzis, 1982; Martin, 2019).

\section{Mangel på direkte samhandling}

I dag vanskeliggjør komplekse hierarkier nærhet, noe som kan bidra til attribusjonsfeil om ledernes personligheter og agendaer (Hackman \& Wageman, 2007). Noe forskning indikerer også at 150 er det maksimale antallet mennesker som kan fungere som en gruppe uten bruk av noen former for makt (Dunbar, 1993). Organisatorisk kompleksitet representerer derfor en utfordring for moderne ledere, spesielt når de bruker en stadig større andel av tiden sin på administrative spørsmål. Når det gjelder 
hormoner, kan denne mangelen på interaksjon påvirke kortisol- og oksytocinnivåer og forårsake mistillit, stress og dårlige forhold mellom mennesker. Dette skyldes at ulike hormoner stimuleres eller hemmes av eksempelvis fysisk berøring og øyekontakt som oppstår ved menneskelig interaksjon.

\section{Partiske beslutningsprosesser}

En rekke forskningsbidrag indikerer at menneskelig beslutningstagning kan være partisk (f.eks. Epley \& Gilovich, 2006; Harris \& Sen, 2019; Tversky \& Kahneman, 1974; Wason, 1960). Beslutningstagning i grupper, felles eierskap til viktige prosesser og delt informasjon sikrer at dominerende individer ikke har full kontroll over beslutningsprosesser, og vi unngår dermed såkalt "gruppetenkning» (Janis, 1972). Det er sannsynlig at mennesker tar gale beslutninger ved vurderingen av premisser, noe som kan ha kostbare konsekvenser (Haselton \& Nettle, 2006; Van Vugt \& Ronay, 2013). Overmot kan bidra til å gi ledere større fordeler og økt sosial status, og dermed evolusjonære fordeler (Anderson, Brion, Moore \& Kennedy, 2012). I følge Von Hippel og Trivers (2011) kan overmot resultere i skjevheter, illusjoner om kontroll og eskalerende forpliktelser. Overmot, spesielt kombinert med kognitive bias eller personlighetstrekk som karisma, kan bidra til at relativt ufaglærte personer oppnår illusorisk overlegenhet (Kruger \& Dunning, 1999), noe som kan være skadelig for organisasjoner. Når det gjelder hormoner, kan testosteron igjen spille en rolle i å forsterke slike bias hos ledere, men her kan også effekten av adrenalin så vel som kortisol være av betydning. Mellommenneskelig interaksjon hvor det står mye på spill, vil eksempelvis bidra til å øke testosteronnivåene til de som opplever at de eller deres lag «vinner», mens det motsatte vil kunne forekomme hos de som opplever nederlag.

Noe som kan redusere ledereffektiviteten er når ledere må fatte beslutninger i komplekse situasjoner, gjerne på mangelfullt faktagrunnlag. Nevrologisk kan det hevdes at alle individer har en form for bias knyttet til beslutningstagning grunnet vårt limbiske system i hjernen (de Martino, Kumaran, Seymour \& Dolan, 2006). Menneskelig intelligens er avhengig av hukommelsens evne til problemløsning og den prefrontale cortex. 
Forskning har vist at hjernecellene danner bedre assosiasjoner når den prefrontale cortex beholder informasjon over lengre tid (Colom, Rebollo, Palacios, Juan-Espinosa \& Kyllonen, 2004). For å gjøre dette, trenger hjernen å filtrere ut ineffektive tanker. Denne behandlingen foregår i den prefrontale cortex. Denne delen av hjernen var imidlertid ikke designet for å håndtere enorme datamengder. Følgelig prøver den prefrontale cortex å konsolidere informasjon for å håndtere datamengden og parallell prosessering (Dijksterhuis, 2004). Når cortex er overbelastet, kan dette føre til villedende snarveier, og folk kan ha problemer med å fatte beslutninger. Studier har vist at den første reaksjonen kan bli dominerende (Bechara, Damasio, Tranel \& Damasio, 1997; Knutson, Rick, Wimmer, Prelec \& Lowenstein, 2007). Bechara og kolleger (1997) bruker naturlig utvalg som en metafor for denne «konkurransen» i hjernen, hvor de sterkere følelser får et konkurransefortrinn over de svakere følelsene. Denne konkurransen er for det meste ubevisst (Kimura, Kubota, Hirose, Yumoto \& Salakihara, 2004), dvs. at ubevisst bearbeiding påvirker folks atferd, i tillegg til å være en mulig kilde til bias i beslutningstagning.

\section{Mangel på selvdisiplin}

Selvdisiplin er den egenskapen som gjør at noen kan fortsette å gjøre noe, selv om det er både strevsomt eller kjedelig. Mennesker har evnen til å overstyre sine impulser, endre sin indre sinnstilstand, påvirke tankene og på andre måter endre sin atferd. Selvdisiplin er en sentral dimensjon av domenet viljestyrke, som blir sett på som en av de mest karakteristiske menneskelige evnene (Baumeister \& Tierney, 2011; Brooks, 2008). Fra et lederperspektiv har mange forskere diskutert evnen til besluttsomhet (Collins, 2001) og utførelse (Bruch \& Ghoshal, 2004) som trengs for å oppnå mål i organisasjoner. Egenskaper som er forbundet med selvdisiplin er blant annet hardt arbeid og utholdenhet, som ofte blir sett på som viktige egenskaper for ledere (Yukl, 2013) Studier har vist at viljestyrke kan være viktig i situasjoner der ledelse blir tatt eller mistet, fordi den mest målbevisste personen i gruppen vil ha en tendens til å lede an (Karp, 2015). Det kan derfor hevdes at ledelseshandlinger er et resultat av hendelsesstyrte situasjoner. Dette er særlig uttalt når en situasjon er utfordrende 
eller usikker, fordi folk da er villige til å la seg lede, ifølge evolusjonspsykologer (Hollander, 1992).

Forskning har identifisert både fysiske og mentale forandringer hos individer som utfører handlinger som krever viljestyrke. Disse kan føre til at impulser hindres midlertidig, og dermed hjelpe til med å fokusere på å oppnå mål til tross for hindringer (Segerstrom \& Nes, 2007). Denne mekanismen påvirkes trolig også av testosteron og kortisol. Funn indikerer også at store endringer i hjerterytmen når man blir stilt overfor en utfordring antyder en stressmotstand i form av økt evne til fokusert oppmerksomhet samtidig som man beholder roen (Appelhans \& Luecken, 2006).

\section{Diskusjon}

Hvorfor er effektiv ledelse så sjelden? Effektiv ledelse karakteriseres av allsidighet: evnen til å påta seg flere, til og med motstridende, roller og ansvarsoppgaver (Kaiser, Lindberg \& Craig, 2007). Dette legger et enormt press på individer i lederstillinger og kan bidra til at så mange mislykkes og den høye utskiftningen av toppledere (Stein \& Capape, 2009).

Lederutviklingskurs har blitt tilbudt ledere for å effektivisere utøvelsen av lederrollen. Denne type trening bygger på en antakelse om at ledelse er noe som faktisk kan læres. Kanskje bør man også stille spørsmål ved hvorvidt alle kan lære å bli gode ledere, og om hormoner kan bidra til å styre atferd og impulser som vanskelig kan læres eller avlæres.

Det er også andre kilder til makt i organisasjoner bortsett fra ledelsen. Studier viser at ledelseshandlinger ser ut til å være mer sjeldne og subtile enn ofte antydet (Karp, 2013). Fenomenet ledelse, og hva det er mulig for ledere å lære og oppnå, kan hevdes å være romantisert (Meindl, Ehrlich \& Dukerich, 1985). Longitudinelle, eksperimentelle, multiple og utforskende studier av ledelse er sjeldne, og nye tilnærminger kan være nødvendige for å fremskaffe ny kunnskap.

Nye funn innen fagfelt som nevrovitenskap og endokrinologi kan kaste nytt lys på vår forståelse av ledelse. Av spesiell interesse er spesifikke hormoner, hormoninteraksjoner og deres koblinger til lederatferd. Tidligere har dyreforsøk undersøkt effekten av hormoner på fysiologi og 
atferdsendring. I dag har hormonforskningen beveget seg til å omfatte mer kompleks atferd, inkludert sosiale prosesser som ledelse og det å bli ledet (Mehta \& Josephs, 2011; Sapolsky, 2017). Slike studier kan gi ny innsikt i hvorfor mange ledere er ineffektive. Hormondata kan sammenstilles med resultatene fra vitenskapelige eksperimenter, observasjoner og evalueringer av situasjoner med lederskap og medarbeiderskap, slik at forskere kan utforske hypoteser for å forklare lederatferd videre. Fremtidig forskning bør derfor i økende grad studere hvorvidt ledelseseffektivitet korrelerer med svingninger i hormonnivåer, og en leders evne til å håndtere hendelsesstyrte situasjoner som involverer kompleksitet, usikkerhet og motstridende forventninger i et hektisk og tvetydig arbeidsmiljø.

\section{Konklusjon}

Ledere leder ikke alltid effektivt. Barrierer for effektivt lederskap eksisterer både i organisasjoner så vel som i ethvert menneske. Barrierer for effektivt lederskap kan føre til at organisasjoner ikke velger de rette menneskene til høyere lederstillinger, og kan være en viktig årsak til organisatorisk ineffektivitet, dårlig gruppedynamikk og mangel på selvregulering.

En plausibel forklaring på eksistensen av slike barrierer er svingninger i hormonnivåer blant ledere og medarbeidere. Denne hypotesen trenger videre undersøkelse. Nivåer av testosteron, kortisol, adrenalin og oksytocin er av interesse, og longitudinelle studier som studerer sammenhengen mellom hormondata og mål for ledelseseffektivitet er en metode for å øke forståelsen for hvorfor ledere ikke oftere benytter seg av effektive lederteknikker. Teknologien for å måle hormonnivåer har blitt mer avansert de siste årene, og det er mulig å måle hormonnivåer både ved bruk av spytt- eller hårprøver for flere hormoner.

Aktører som tilbyr lederutvikling, som f.eks. prestisjetunge universiteter og konsulentselskaper, tilbyr utdannings- og lederutviklingsprogrammer til dem som har råd til å betale. Det kan imidlertid hevdes at ikke alle nødvendigvis er i stand til å bli en effektiv leder. Det finnes grenser for hva utdanning og opplæring kan rette opp i når det kommer til menneskelig bias, atferd og beslutningsfeil. Prosesser som innebærer menneskelig samhandling i organisasjoner har selvfølgelig en sentral 
sosial komponent, men i vår iver etter å undersøke og forstå de sosiale aspektene ved ledelse, har mange forskere unnlatt å utforske de biologiske komponenter fullt ut.

\section{Referanser}

Alvesson, M. (2019). Waiting for Godot: Eight major problems in the odd field of leadership studies. Leadership, 15(1), 27-3. https://doi.org/10.1177/1742715017736707

Anderson, C., Brion, S., Moore, D. A. \& Kennedy, J. A. (2012). A status-enhancement account of overconfidence. Journal of Personality and Social Psychology, 103(4), 718-735. https://doi.org/10.1037/aoo29395

Antonakis, J. \& Day, D. V. (Red.). (2018). The nature of leadership. Thousand Oaks, CA: Sage publications.

Appelhans, B. M. \& Luecken, L. J. (2006). Heart rate variability as an index of regulated emotional responding. Review of General Psychology, 10(3), 229-240. https://doi.o rg/10.1037/1089-2680.10.3.229

Archer, J. (2006). Testosterone and human aggression: An evaluation of the challenge hypothesis. Neuroscience and Biobehavioral Reviews, 30(3), 319-345. https://doi.org/10.1016/j.neubiorev.2004.12.007

Babiak, P. \& Hare, R. D. (2009). Snakes in suits. New York: Harper Collins.

Bass, B. M. (1985). Leadership and performance beyond expectations. New York: Free Press.

Bass, B. M. \& Stogdill, R. M. (1990). Bass \& Stogdill's handbook of leadership: Theory, research, and managerial applications. Simon and Schuster.

Bass, B. M. (1996). A new paradigm of leadership: An inquiry into transformational leadership. Alexandria, VA: US Army Research Institute for the Behavioral and Social Sciences.

Bass, B. M., \& Bass, R. (2009). The Bass handbook of leadership: Theory, research, and managerial applications. New York: Simon \& Schuster.

Baumeister, R. F. \& Tierney, J. (2011). Willpower. Rediscovering the greatest human strength. New York: The Penguin Press.

Bechara, A., Damasio, H., Tranel, D. \& Damasio, A. (1997). Deciding advantageously before knowing the advantageous strategy. Science, 275(5304), 1293-1295. Hentet fra https://science.sciencemag.org/content/275/5304/1293

Binney, G., Wilke, G. \& Williams, C. (2005). Living leadership. A practical guide for ordinary heroes. Harlow: Pearson Education.

Birkinshaw, J. (2013). Becoming a better boss. Why good management is so difficult. Chichester: John Wiley \& Sons. 
Boksem, M. A. S., Mehta, P. H., Van den Bergh, B., van Son, V., Trautmann, S. T., Roelofs, K., Smidts, A. \& Sanfey, A. G. (2013). Testosterone inhibits trust, but promotes reciprocity. Psychological Science, 24(11), 2306-2314. https://doi. org/10.1177/0956797613495063

Boyatzis, R. E. (1982). The competent manager: A model for effective performance. Hoboken, NJ: John Wiley \& Sons.

Breaux, D. M., Perrewé, P. L., Hall, A. T., Frink, D. D. \& Hochwarter, W. A. (2008). Time to try a little tenderness? The detrimental effects of accountability when coupled with abusive supervision. Journal of Leadership \& Organizational Studies, 15(2), 111-122. https://doi.org/10.1177/1548051808321787

Brooks, D. (2008, 6. juni). The art of growing up [Kronikk]. New York Times. Hentet fra https://www.nytimes.com/2008/o6/o6/opinion/o6brooks.html

Bruch, H. \& Ghoshal, S. (2004). A bias for action. Boston, MA: Harvard Business School Publishing.

Burns, J. M. (1978). Leadership. New York: HarperCollins.

Cardona, P. (2000). Transcendental leadership. Leadership \& Organization Development Journal, 21(4), 201-207. https://doi.org/10.1108/01437730010335445

Carlson, S. (1991). Executive behaviour (med H. Mintzberg \& R. Stewart). Uppsala; Sweden: Studia Oeconomiae Negotiorum. (Utgitt 1951.)

Chung, S., Son, G. H. \& Kim, K. (2011). Circadian rhythm of adrenal glucocorticoid: Its regulation and clinical implications. Biochimica et Biophysica Acta (BBA)Molecular Basis of Disease, 1812(5), 581-591. https://doi.org/10.1016/j.bbadis. 2011.02.003

Cohen, S., Schwartz, J. E., Epel, E., Kirschbaum, C., Sidney, S. \& Seeman, T. (2006). Socioeconomic status, race, and diurnal cortisol decline in the coronary artery risk development in young adults (CARDIA) study. Psychosomatic Medicine, 68(1), 41-50. https://doi.org/10.1097/o1.psy.0ooo195967.51768.ea

Colarelli, S. M. \& Arvey, R. D. (Red.). (2015). The biological foundations of organizational behavior. Chicago: University of Chicago Press.

Collins, J. (2001). Level 5 leadership: The triumph of humility and fierce resolve. Harvard Business Review, 79(1), 66-76. Hentet fra https://hbr.org/2001/01/level-5leadership-the-triumph-of-humility-and-fierce-resolve-2

Colom, R., Rebollo, I., Palacios, A., Juan-Espinosa, M. \& Kyllonen, P. C. (2004). Working memory is (almost) perfectly predicted by $g$. Intelligence, 32(3), 277-296. https://doi.org/10.1016/j.intell.2003.12.002

De Dreu, C. K. (2012). Oxytocin modulates cooperation within and competition between groups: An integrative review and research agenda. Hormones and Behavior, 61(3): 419-428. https://doi.org/10.1016/j.yhbeh.2011.12.009

De Dreu, C. K., Greer, L. L., Handgraaf, M. J., Shalvi, S., Van Kleef, G. A. \& Baas, M. (2010). The neuropeptide oxytocin regulates parochial altruism in intergroup 
conflict among humans. Science, 328(5984), 1408-1411. https://doi.org/10.1126/ science.1189047

De Martino, B., Kumaran, D., Seymour, B. \& Dolan, R. J. (2006). Frames, biases and rational decision-making in the human brain. Science, 313(5787), 684-687. https://doi.org/10.1126/science.1128356

Dickerson, S. S. \& Kemeny, M. E. (2004). Acute stressors and cortisol responses: A theoretical integration and synthesis of laboratory research. Psychological Bulletin, 130(3), 355-391. https://doi.org/10.1037/0033-2909.130.3.355

Dijksterhuis, A. (2004). Think different: The merits of unconscious thought in preference development and decision making. Journal of Personality \& Social Psychology, 87(5), 586-598. https://doi.org/10.1037/0022-3514.87.5.586

Dunbar, R. I. M. (1993). Coevolution of neocortex size, group size and language in humans. Behavioral and Brain Sciences, 16(4), 541-553. https://doi.org/10.1017/ So140525Xoo032325

Dweck, C. S. (2006). Mindset. The new psychology of success. How we can learn to fulfil our potential. New York: Ballantine Books.

Eisenegger, C., Haushofer, J. \& Fehr, E. (2011). The role of testosterone in social interaction. Trends in Cognitive Sciences, 15(6), 263-271. https://doi.org/10.1016/ j.tics.2011.04.008

Ennova. (2013). European employee index 2013 (Norge 2013, 14. årgang). Hentet 24. mars 2015 fra http://no.ennova.com/

Epley, N. \& Gilovich, T. (2006). The anchoring-and-adjustment heuristic: Why the adjustments are insufficient. Psychological Science, 17(4), 311-318. https://doi.org/ 10.1111/j.1467-9280.2006.01704.X

Falk, A. \& Kosfeld, M. (2006). The hidden costs of control. American Economic Review, 96(5): 1611-1630. https://doi.org/10.1257/aer.96.5.1611

Fast, N. J., Gruenfeld, D. H., Sivanathan, N. \& Galinsky, A. D. (2009). Illusory control: A generative force behind power's far-reaching effects. Psychological Science, 20(4), 502-508. https://doi.org/10.1111/j.1467-9280.2009.02311.X

Feldman, H. A., Longcope, C., Derby, C. A., Johannes, C. B., Araujo, A. B., Coviello, A. D., ... \& McKinlay, J. B. (2002). Age trends in the level of serum testosterone and other hormones in middle-aged men: Longitudinal results from the Massachusetts male aging study. The Journal of Clinical Endocrinology \& Metabolism, 87(2), 589-598. https://doi.org/10.1210/jcem.87.2.8201

Gallup. (2013). The state of the American workplace: Employee engagement insights for U.S. business leaders (Rapport). Hentet 24. mars 2015 fra www.gallup.com/ services/176708/state-american-workplace.aspx

Garcia, M. C., de Souza, A., Bella, G. P., Grassi-Kassisse, D. M., Tacla, A. P. \& Spadari-Bratfisch, R. C. (2008). Salivary cortisol levels in Brazilian citizens of 
distinct socioeconomic and cultural levels. Annals of the New York Academy of Sciences 1148(1), 504-508. https://doi.org/10.1196/annals.1410.065

Greenleaf, R. K. (1977). Servant leadership: A journey into the nature of legitimate power and greatness. Mahwah, NJ: Paulist Press.

Grewen, K. M., Girdler, S. S., Amico, J. \& Light, K. C. (2005). Effects of partner support on resting oxytocin, cortisol, norepinephrine, and blood pressure before and after warm partner contact. Psychosomatic Medicine, 67(4), 531-538. https://doi.org/10.1097/o1.psy.00oo170341.88395.47

Hackman, J. R. \& Wageman, R. (2007). Asking the right questions about leadership. American Psychologist, 62(1), 43-47. https://doi.org/10.1037/0o03-066X.62.1.43

Hardy, C. L. \& Van Vugt, M. (2006). Nice guys finish first: The competitive altruism hypothesis. Personality and Social Psychology Bulletin, 32(10), 1402-1413. https://doi.org/10.1177/0146167206291006

Harris, K. J., Harvey, P. \& Kacmar, K. M. (2011). Abusive supervisory reactions to coworker relationship conflict. The Leadership Quarterly, 22(5), 1010-1023. https://doi.org/10.1016/j.leaqua.2011.07.020

Harris, A. P. \& Sen, M. (2019). Bias and judging. Annual Review of Political Science, 22, 241-259. https://doi.org/10.1146/annurev-polisci-051617-090650

Haselton, M. G. \& Nettle, D. (2006). The paranoid optimist: An integrative evolutionary model of cognitive biases. Personality and Social Psychology Review, 10(1), 47-66. https://doi.org/10.1207/s15327957pspr10o1_3

Hemphill, J. K. \& Coons, A. E. (1957). Development of the leader behaviour description questionnaire. I R. M. Stogdill \& A. E. Coons (Red.), Leader behaviour: Its description and measurement (s. 6-38). Columbus: Bureau of Business Research, Ohio State University.

Hoch, J. E., Bommer, W. H., Dulebohn, J. H. \& Wu, D. (2018). Do ethical, authentic, and servant leadership explain variance above and beyond transformational leadership? A meta-analysis. Journal of Management, 44(2), 501-529. https://doi. org/10.1177/0149206316665461

Hogan, R. (2006). Personality and the fate of organizations. Hillsdale, NJ: Lawrence Erlbaum.

Hogan, R. \& Kaiser, R. (2005). What we know about leadership. Review of General Psychology, 9, 169-18o. https://doi.org/10.1037/1089-2680.9.2.169

Hollander, E. P. (1985). Leadership and power. I G. Lindzey \& E. Aronson (Red.), Handbook of social psychology (s. 485-537). New York: Random House.

Hollander, E. P. (1992). The essential interdependence of leadership and followership. Current Directions in Psychological Science, 1(2), 71-75. https://doi. org/10.1111/1467-8721.ep11509752

Holmberg, I. \& Tyrstrup, M. (2010). Well then: What now? An everyday approach to managerial leadership. Leadership, 6(4), 353-372. https://doi. org/10.1177/1742715010379306 
Howard, A. \& Bray, D. W. (1988). Managerial lives in transition: Advancing age and changing times. New York: Guilford Press.

Janis, I. L. (1972). Victims of groupthink: A psychological study of foreign-policy decisions and fiascoes. Boston: Houghton Mifflin.

Jensen-Campbell, L. A., Gleason, K. A., Adams, R. \& Malcolm, K. T. (2003). Interpersonal conflict, agreeableness, and personality development. Journal of Personality, 71(6), 1059-1086. https://doi.org/10.1111/1467-6494.7106007

Josephs, R. A., Sellers, J. G., Newman, M. L. \& Mehta, P. H. (2006). The mismatch effect: When testosterone and status are at odds. Journal of Personality and Social Psychology, 9o(6), 999-1013. https://doi.org/10.1037/0022-3514.90.6.999

Jurevičienè, M., Kaffemanienè, I. \& Ruškus, J. (2012). Concept and structural components of social skills. Baltic Journal of Sport and Health Sciences, 3(86). https://doi.org/10.33607/bjshs.v3i86.266

Kaiser, R. B., Lindberg, J. T. \& Craig, S. B. (2007). Assessing the flexibility of managers: A comparison of methods. International Journal of Selection and Assessment, 15(1), 40-55. https://doi.org/10.1111/j.1468-2389.2007.00366.x

Kamin, H. S., \& Kertes, D. A. (2017). Cortisol and DHEA in development and psychopathology. Hormones and behavior, 89, 69-85.

Karp, T. (2013). Studying subtle acts of leadership. Leadership, 9(1), 3-22. https://doi. org/10.1177/1742715012447007

Karp, T. (2015). Is willpower important for acts of leadership? Leadership, 11(1), 20-35. https://doi.org/10.1177/1742715013498406

Karp, T. (2018). We are asking the wrong question about leadership: The case for 'good-enough' leadership. I M. F. Brandebo \& A. Alvinius (Red.), Dark sides of organizational behavior and leadership. https://doi.org/10.5772/intechopen.74842

Karp, T. \& Johannessen, J. A. (2010). Earning the right to lead in defining moments: The act of taking leadership. Journal of Values-based Leadership, 3(1), 42-60. Hentet fra https://scholar.valpo.edu/jvbl/vol3/iss1/4

Kellerman, B. (2012). The end of leadership. New York: HarperCollins Publishers.

Kimura, I., Kubota, M., Hirose, H., Yumoto, M. \& Sakakihara, Y. (2004). Children are sensitive to averted eyes at the earliest stage of gaze processing. NeuroReport, 15(8), 1345-1348. https://doi.org/10.1097/01.wnr.0ooo129574.43925.59

Kipnis, D. (1972). Does power corrupt? Journal of Personality and Social Psychology, 24(1), 33-41. https://doi.org/10.1037/hoo3339o

Knight, E. L. \& Mehta, P. H. (2014). Hormones and hierarchies. I J. T. Cheng, J. L. Tracy \& C. Anderson (Red.), The psychology of social status (s. 269-302). New York: Springer.

Knutson, B., Rick, S., Wimmer, G. E., Prelec, D. \& Lowenstein, G. (2007). Neural predictors of purchases. Neuron, 53(1), 147-156. https://doi.org/10.1016/j. neuron.2006.11.010 
Kosfeld, M., Heinrichs, M., Zak, P. J., Fischbacher, U. \& Fehr, E. (2005). Oxytocin increases trust in humans. Nature, 435(7042): 673-676. https://doi.org/10.1038/ natureo3701

Kotter, J. P. (1999). John P. Kotter on what leaders really do. Boston, MA: Harvard Business Press.

Kremer, J. \& Mack, D. (1983). Pre-emptive game behavior and the emergence of leadership. British Journal of Social Psychology, 22(1), 19-26. https://doi. org/10.1111/j.2044-8309.1983.tboo561.x

Kruger, J. \& Dunning, D. (1999). Unskilled and unaware of it: how difficulties in recognizing one's own incompetence lead to inflated self-assessments. Journal of personality and social psychology, 77(6), 1121. https://doi.org/10.1037//00223514.77.6.1121

Lammers, J., Galinsky, A. D., Gordijn, E. H. \& Otte, S. (2008). Illegitimacy moderates the effects of power on approach. Psychological Science, 19(6), 558-564. https://doi.org/10.1111/j.1467-9280.2008.02123.x

Lindfors, P. \& Lundberg, U. (2002). Is low cortisol release an indicator of positive health? Stress and Health, 18(4), 153-16o. https://doi.org/10.1002/smi.942

Lischke, A. (2013). Oxytocin effects on emotion recognition under conditions of unlimited and limited awareness (Doktorgradsavhandling, Ruprecht-KarlsUniversität Heidelberg). https://doi.org/10.11588/heidok.0oo16010

Luthans, F., Hodgetts, R. M. \& Rosenkrantz, S. A. (1988). Real managers. Cambridge, MA: Ballinger.

Magee, J. C. \& Galinsky, A. D. (2008). Social hierarchy: The self-reinforcing nature of power and status. Academy of Management annals, 2(1), 351-398. https://doi. org/10.5465/19416520802211628

Martin, M. A. (2019). Servant leadership characteristics and empathic care: Developing a culture of empathy in the healthcare setting (Doktorgradsavhandling, Antioch University). Hentet fra https://aura.antioch.edu/etds/525/

Mazur, A. (1985). A biosocial model of status in face-to-face primate groups. Social Forces, 64(2), 377-402. https://doi.org/10.2307/2578647

Mehta, P. H. \& Josephs, R. A. (2011). Social endocrinology: Hormones and social motivation. I D. Dunning (Red.), Frontiers of social psychology: Social motivation (s. 171-190). New York: Psychology Press.

Mehta, P. H., Jones, A. C. \& Josephs, R. A. (2008). The social endocrinology of dominance: basal testosterone predicts cortisol changes and behavior following victory and defeat. Journal of personality and social psychology, 94(6), 1078-1093. https://doi.org/10.1037/0022-3514.94.6.1078

Meindl, J. R., Ehrlich, S. B. \& Dukerich, J. M. (1985). The romance of leadership. Administrative Science Quarterly, 30(1), 78-102. https://doi.org/10.2307/2392813 
Mezulis, A., Abramson, L., Hyde, J. S. \& Hankin, B. L. (2004). Is there a universal positively bias in attributions? A meta-analytic review of individual, developmental, and cultural differences in the self-serving attributional bias. Psychological Bulletin, 130(5), 711-746. https://doi.org/10.1037/0033-2909.130.5.711

Milgram, S. (1963). Behavioral study of obedience. The Journal of Abnormal and Social Psychology, 67(4), 371-387. https://doi.org/10.1037/hoo40525

Mintzberg, H. (1973). The nature of managerial work. New York: Harper Row Publishers.

Nissen, I. (1945). Psykopatenes diktatur. Oslo: Aschehoug.

Padilla, A., Hogan, R. \& Kaiser, R. B. (2007). The toxic triangle: Destructive leaders, vulnerable followers, and conducive environments. The Leadership Quarterly, 18(3), 176-194. https://doi.org/10.1016/j.leaqua.2007.03.001

Pfeffer, J. \& Sutton, R. I. (2000). The knowing-doing gap. How smart companies turn knowledge into action. Boston: Harvard Business School Press.

Ronay, R. \& Carney, D. R. (2013). Testosterone's negative relationship with emphatic accuracy and perceived leadership ability. Social Psychological and Personality Science, 4(1), 92-99. https://doi.org/10.1177/1948550612442395

Rose, K., Shuck, B., Twyford, D. \& Bergman, M. (2015). Skunked an integrative review exploring the consequences of the dysfunctional leader and implications for those employees who work for them. Human Resource Development Review, 14(1), 64-9o. https://doi.org/10.1177/1534484314552437

Rotter, J. B. (1966). Generalized expectancies for internal versus external control of reinforcement. Psychological Monographs, 8o(1), 1-28. https://doi.org/10.1037/ hoog2976

Ryff, C. D., Singer, B. H. \& Love, G. D. (2004). Positive health: Connecting wellbeing with biology. Philosophical Transactions-Royal Society of London Series B Biological Sciences, 359(1449), 1383-1394. https://doi.org/10.1098/rstb.2004.1521

Sapolsky, R. M. (1999). Glucocorticoids, stress, and their adverse neurological effects: Relevance to aging. Experimental Gerontology, 34(6), 721-732. https://doi. org/10.1016/so531-5565(99)0o047-9

Sapolsky, R. M. (2017). Behave: The biology of humans at our best and worst. London: Penguin.

Segerstrom, S. C. \& Nes, L. S. (2007). Heart rate variability reflects self-regulatory strength, effort, and fatigue. Psychological Science, 18(3), 275-281. 10.1111/j.14679280.2007.01888.x

Sherman, G. D., Lee, J. J., Cuddy, A. J., Renshon, J., Oveis, C., Gross, J. J. \& Lerner, J. S. (2012). Leadership is associated with lower levels of stress. Proceedings of the National Academy of Sciences, 109(44), 17903-17907. https://doi.org/10.1073/ pnas.1207042109 
Stein, G. \& Capape, J. (2009). The factors behind the failure rate of CEOs. IESE insight. Hentet 23. oktober 2009 fra http://insight.iese.edu/doc.aspx?id=1019\&ar=2O

Steptoe, A., Kunz-Ebrecht, S., Owen, N., Feldman, P. J., Willemsen, G., Kirschbaum, C. \& Marmot, M. (2003). Socioeconomic status and stress-related biological responses over the working day. Psychosomatic Medicine, 65(3), 461-470. https:/7doi.org/10.1097/01.psy.00oo035717.78650.a1

Stewart, R. (1988). Managers and their jobs: A study of the similarities and differences in the ways managers spend their time (2. utg.). Basingstoke: The Macmillan Press. (Utgitt 1967.)

Szulc, P., Hofbauer, L. C., Heufelder, A. E., Roth, S. \& Delmas, P. D. (2001). Osteoprotegerin serum levels in men: Correlation with age, estrogen, and testosterone status 1. The Journal of Clinical Endocrinology \& Metabolism, 86(7), 3162-3165. https://doi.org/10.1210/jcem.86.7.7657

Taylor, S. E., Gonzaga, G. C., Klein, L. C., Hu, P., Greendale, G. A. \& Seeman, T. E. (2006). Relation of oxytocin to psychological stress responses and hypothalamicpituitary-adrenocortical axis activity in older women. Psychosomatic medicine, 68(2), 238-245. https://doi.org/10.1097/01.psy.00oo203242.95990.74

Telfer, J. (2013, 1. mars). Bosses behaving badly. Training Journal, 44-48. Hentet fra https://www.trainingjournal.com/articles/feature/bosses-behaving-badly

Tengblad, S. (2013). The work of managers. Towards a practice theory of management. Oxford: Oxford University Press.

Tops, M., van Peer, J. M., Korf, J., Wijers. A. A. \& Tucker, D. M. (2007). Anxiety, cortisol, and attachment predict plasma oxytocin. Psychophysiology, 44(3), 444-449. https://doi.org/10.1111/j.1469-8986.2007.00510.x

TUC. (2008, september). What do workers want? (Rapport fra meningsmåling). Hentet fra http://www.mas.org.uk/uploads/artlib/tuc-what-do-workers-want.pdf Turner, R. A., Altemus, M., Enos, T., Cooper, B. \& McGuinness, T. (1999). Preliminary research on plasma oxytocin in normal cycling women: Investigating emotion and interpersonal distress. Psychiatry, 62(2), 97-113. https://doi.org/10.10 8o/00332747.1999.11024859

Tversky, A. \& Kahneman, D. (1974). Judgment under certainty: Heuristic and biases. Science, 185(4157), 1124-1131. https://doi.org/10.1126/science.185.4157.1124

Van Vugt, M. \& Ronay, R. (2013). The evolutionary psychology of leadership: Theory, review, and roadmap. Organizational Psychology Review, 4(1), 74-95. https://doi. org/10.1177/2041386613493635

Von Hippel, W. \& Trivers, R. (2011). The evolution and psychology of self-deception. Behavioral and Brain Sciences, 34(1), 1-16. https://doi.org/10.1017/So140525X10001354

Wason, P. C. (1960). On the failure to eliminate hypotheses in a conceptual task. Quarterly Journal of Experiemental Psychology, 12, 129-140. https://doi. org/10.1080/17470216008416717 
Winslow, J. T., Ellingboe, J. \& Miczek, K. A. (1988). Effects of alcohol on aggressive behavior in squirrel monkeys: Influence of testosterone and social context. Psychopharmacology, 95(3), 356-363. https://doi.org/10.1007/BFoo181947 Yukl, G. (2013). Leadership in organizations (8. utg.) Boston: Pearson.

Yukl, G., Gordon, A. \& Taber, T. (2002). A hierarchical taxonomy of leadership behavior: Integrating a half century of behavior research. Journal of Leadership and Organisation Studies, 9(1) 15-32. https://doi.org/10.1177/107179190200900102

Zak, P. J., Kurzban, R. \& Matzner, W. T. (2005). Oxytocin is associated with human trustworthiness. Hormones and Behavior, 48(5), 522-527. Hentet fra https:// citeseerx.ist.psu.edu/viewdoc/download?doi=10.1.1.97.6o82\&rep=rep1\&type=pdf

Zitzmann, M. \& Nieschlag, E. (2001). Testosterone levels in healthy men and the relation to behavioural and physical characteristics: Facts and constructs. European Journal of Endocrinology, 144(3), 183-197. https://doi.org/10.1530/ eje.o.1440183 



\section{Forfatterbiografier}

Nils Arne Bakke er professor i digitaløkonomi og teknologiledelse ved Høyskolen Kristiania. Han er Dr.ing i industriell økonomi fra NTNU, har IT-utdannelse fra $\mathrm{UiB}$, en magistergrad i sosiologi fra $\mathrm{UiO}$, og har publisert et 2o-talls bøker og artikler innen ledelse, bedriftsøkonomiske fag og logistikk. Bakke har omfattende erfaring som toppleder innen norske og internasjonale software- og teknologibedrifter, og har en rekke styreverv i slike virksomheter.

Jens Barland er medieforsker og førsteamanuensis i kommunikasjon og medieledelse ved Høyskolen Kristiania, hvor han også er dekan for avdelingen School of Communication, Leadership, and Marketing. Han har tidligere jobbet ved NTNU og har sin doktorgrad om innovasjon av journalistikk fra Universitet i Oslo. Før det jobbet han 20 år i pressen, og har blant annet vært sjefredaktør og adm. dir. for Stavanger Aftenblad.

Jarle Bastesen er førsteamanuensis i organisasjon og ledelse ved Institutt for Ledelse og organisasjon ved Høyskolen Kristiania. Hans doktorgrad fra Norges Handelshøyskole (NHH) handler om raskt voksende bedrifter, såkalte gaseller, og hvilken egenskaper og forhold som gjør at disse lykkes og ikke lykkes over tid. Bastesen forsker også på organisasjonsutvikling, ledelse, entreprenørskap, atypiske tilknytningsformer i arbeidslivet og pedagogiske virkemidler i høyere utdanning.

Thea Renate Berg er forskningsassistent ved Institutt for ledelse og organisasjon, Høyskolen Kristiania. Hun fullfører en master i Organisasjon, Ledelse og Arbeid på UiO våren 2021. I masteroppgaven skriver hun om psykologisk trygghet i et rolleteoretisk perspektiv. Hun har forskningsinteresse knyttet til ledelse, organisasjonslæring og organisasjonspsykologi. 
Rune Bjerke er førsteamanuensis i markedsføring ved Institutt for Ledelse og organisasjon ved Høyskolen Kristiania. Han er ph.d. fra Otago University, New Zealand, og underviser i Brand Management, selvledelse, Event Management, and Sponsorship Management. Han har ansvar for et emne i selvledelse ved Handelshøyskolen i Bodø og Universitetet i Sørøst-Norge. Bjerke har publisert bøker om merkevarebygging og event- og sponsormanagement, og en rekke artikler om helseledelse, arrangementsledelse, sponsorutvikling og merkevarebygging. Bjerke har lenge vært en del av HSMAI Event Awards, deriblant fire år som juryleder, og er også juryleder for Sponsor- og Eventprisen siden 2017.

Irmelin Drake er førsteamanuensis i ledelse ved Høyskolen Kristiania og studieprogramleder for Master i ledelse samme sted. Hun er ph.d. i strategi og ledelse fra Norges Handelshøyskole (NHH) og har i den senere tid forsket på og skrevet om stakeholder perspektiver på ledelse, ledelse av sosial innovasjon, kvinners toppkarrierer i akademia og ledelse av mangfoldsprosjekter.

Arild Fetveit er ph.d. fra Universitetet i Oslo, medieforsker og arbeider for Aletheia Media. Han har publisert innenfor resepsjonsforskning, konvergens, medium-spesifikk støy, musikkvideo og digitalisering av film og fotografi. Han har blant annet publisert i Norsk medietidsskrift, Screen, Media, Culture and Society, International Journal of Cultural Studies og NECSUS. Han arbeider i øyeblikket med to prosjekter, et om forretningsmodeller for journalistikk og et om hvordan kunstig intelligens redefinerer beviskraften til fotografiske bilder.

Anne Haugen Gausdal er professor i organisasjon, ledelse og innovasjon og prodekan for forskning ved Høyskolen Kristiania og professor II på UiT Norges arktiske universitet. Hun har ph.d. i bedriftsøkonomi fra NORD universitet. Hennes forskningsområder er tillit og tillits bygging, innovasjons-metodikk, regional innovasjon og ledelse innenfor bla sikkerhet, beredskap, nettverk og digitalisering.

Birthe Kåfjord Lange er førsteamanuensis i ledelse ved Høyskolen Kristiania. Hun har doktorgrad i ledelse fra NHH i 2008. Kåfjord Lange 
har 10 års erfaring fra leder- og kompetanseutvikling, blant annet i Equinor og som direktør for NHH Executive. Hun har også bred og variert styreerfaring. Langes doktorgrad omhandlet norske lederes håndtering av tid. Hun har også forsket ulike ledelsestema som lederes strategiske handlingsrom, hvordan ledere håndterer strategisk endring i krisetider betydningen av tillit og psykologisk trygghet i radikale endringsprosesser, lederutvikling, samt HRs ulike roller.

Ola Martin Jensen Larsen er doktorgradsstipendiat ved Høyskolen Kristiania med utdanningsbakgrunn innen ledelse og økonomi fra henholdsvis Høyskolen Kristiania og Høgskulen på Vestlandet. Doktorgradsprosjektet omhandler temaet arbeidsinkludering, men han har også forskningsrelaterte interesser innen bærekraft og varsling.

Helene Tronstad Moe er førsteamanuensis innen arbeids- og organisasjonspsykologi ved Høyskolen Kristiania. Hun foreleser i fagene rekruttering, differensialpsykologi og arbeids- og organisasjonspsykologi. Hun har erfaring fra næringslivet innen arbeid med rekruttering, lederevaluering, organisasjonspsykologi, samt arbeidspsykologiske testverktøy.

Hans Erik Næss er førsteamanuensis i idrettsledelse ved Høyskolen Kristiania og redaktør for Norsk sosiologisk tidsskrift. Han er ph.d. i sosiologi fra Universitetet i Oslo og har skrevet en rekke artikler og bøker om organisasjonsutvikling, ansvarlig styring, menneskerettigheter og bærekraft i idretten.

Mari Svendsen er førsteamanuensis i organisasjon og ledelse ved Høyskolen Kristiania. Hun er psykolog og har en ph.d i arbeid og organisasjonspsykologi fra Aarhus Universitet. Mari har har publisert vitenskapelige artikler innenfor temaene ledelse, mestring og organisatorisk proaktivitet.

Andreas Thon er instituttleder og høyskolelektor ved Institutt for ledelse og organisasjon, Høyskolen Kristiania. Han har en Master of Arts fra University of Hertfordshire og Krigsskolen i Hæren. Thons 
forskningsinteresser er i første rekke ledelse, organisasjonsadferd, strategisk HR og læring gjennom praksis.

Elin Ørjasæter er dosent ved Høyskolen Kristiania. Hun er utdannet samfunnsgeograf ved Universitetet i Oslo (1988) og har arbeidet som forhandler i fagforening, personaldirektør, bedriftsrådgiver, headhunter, personaldirektør og kommentator i dagspressen. 